\title{
Phylogenetic relationships of the South American Doradoidea (Ostariophysi: Siluriformes)
}

\author{
José L. O. Birindelli
}

A phylogenetic analysis based on 311 morphological characters is presented for most species of the Doradidae, all genera of the Auchenipteridae, and representatives of 16 other catfish families. The hypothesis that was derived from the six most parsimonious trees support the monophyly of the South American Doradoidea (Doradidae plus Auchenipteridae), as well as the monophyly of the clade Doradoidea plus the African Mochokidae. In addition, the clade with Sisoroidea plus Aspredinidae was considered sister to Doradoidea plus Mochokidae. Within the Auchenipteridae, the results support the monophyly of the Centromochlinae and Auchenipterinae. The latter is composed of Tocantinsia, and four monophyletic units, two small with Asterophysus and Liosomadoras, and Pseudotatia and Pseudauchenipterus, respectively, and two large ones with the remaining genera. Within the Doradidae, parsimony analysis recovered Wertheimeria as sister to Kalyptodoras, composing a clade sister to all remaining doradids, which include Franciscodoras and two monophyletic groups: Astrodoradinae (plus Acanthodoras and Agamyxis) and Doradinae (new arrangement). Wertheimerinae, new subfamily, is described for Kalyptodoras and Wertheimeria. Doradinae is corroborated as monophyletic and composed of four groups, one including Centrochir and Platydoras, the other with the large-size species of doradids (except Oxydoras), another with Orinocodoras, Rhinodoras, and Rhynchodoras, and another with Oxydoras plus all the fimbriate-barbel doradids. Based on the results, the species of Opsodoras are included in Hemidoras; and Tenellus, new genus, is described to include Nemadoras trimaculatus, $N$. leporhinus and Nemadoras ternetzi. Due to conflicting hypotheses of the phylogenetic position of Acanthodoras, Agamyxis, and Franciscodoras, these are considered as incertae sedis in Doradidae. All suprageneric taxa of the Doradoidea are diagnosed based on synapomorphic morphological characteristics.

Uma análise filogenética com base em 311 caracteres morfológicos é apresentada para a maioria das espécies de Doradidae, todos os gêneros de Auchenipteridae e representantes de outras 16 famílias de Siluriformes. A hipótese de consenso entre as seis árvores mais parcimoniosas corrobora o monofiletismo do grupo Sul-americano Doradoidea (Doradidae mais Auchenipteridae), bem como o de Doradoidea mais a família Africana Mochokidae. O clado de Sisoroidea mais Aspredinidae é considerado como grupo-irmão de Doradoidea mais Mochokidae. Dentre os Auchenipteridae, os resultados corroboraram o monofiletismo de Centromochlinae e Auchenipterinae. Esta última inclui Tocantinsia e outros quarto grupos monofiléticos, um com Asterophysus e Liosomadoras, um com Pseudotatia e Pseudauchenipterus, e outros dois maiores com os demais gêneros da subfamília. Dentre os Doradidae, a análise de parcimônia recuperou Wertheimeria como grupo-irmão de Kalyptodoras, formando um clado irmão de todos os demais doradídeos, que incluem Franciscodoras e dois grupos: Astrodoradinae (mais Acanthodoras e Agamyxis) e Doradinae (arranjo novo). Wertheimerinae, subfamília nova, é descrita para os gêneros Kalyptodoras e Wertheimeria. Doradinae é corroborada como monofilética e composta por quatro grupos de espécies, o primeiro com Centrochir e Platydoras, o segundo com os doradídeos de grande porte (exceto Oxydoras), o terceiro com Orinocodoras, Rhinodoras e Rhynchodoras, e o quarto com Oxydoras e os doradídeos de barbilhões fimbriados. Com base nos resultados, Opsodoras é considerado como sinônimo júnior de Hemidoras; e Tenellus, gênero novo, é descrito para Nemadoras trimaculatus, $N$. leporhinus e Nemadoras ternetzi. Devido à existência de hipóteses conflitantes para a posição filogenética de Acanthodoras, Agamyxis e Franciscodoras, estes são considerados como incertae sedis em Doradidae. Todos os grupos supra-genéricos de Doradoidea são diagnosticados com base em caracteres morfológicos sinapomórficos.

Key words: Systematics, Taxonomy, Neotropical, Catfishes.

Departamento de Biologia Animal e Vegetal, Universidade Estadual de Londrina. Caixa Postal 10.001, 86057-970 Londrina, PR, Brazil. josebirindelli@yahoo.com. 


\section{Introduction}

Siluriformes comprises the most morphologically diverse, and geographically widespread order of Ostariophysi, with approximately 36 families, 477 genera, and 3088 valid species (Ferraris, 2007). Although most species are restricted to freshwaters, some are tolerant of brackish waters, and one family occurs almost exclusively in marine environments (Nelson, 2006).

Within the Siluriformes, the superfamily Doradoidea comprises two Neotropical families: Doradidae and Auchenipteridae. The species of Doradoidea range in length from a few centimeters (e.g., Physopyxis, Gelanoglanis) to a little more than one meter (e.g., Oxydoras). Most species are exclusive to freshwaters and occur in the largest river basins in South America, such as: Amazonas, La Plata, São Francisco, Parnaíba, Mearim, Orinoco, Magdalena, Maracaibo, Essequibo, and coastal rivers of Guyana, French Guiana, and Suriname. They are distinguished from other catfishes by having a wide well-developed cephalic shield that is continuous to the dorsal-fin spine, posterior cleithral process usually large, and an infranuchal ligament (= ligament between posterior nuchal plate and rib of sixth vertebra; Birindelli et al., 2009; Birindelli et al., 2012).

The species of Doradidae are popularly known as thorny or talking catfishes (international community); cuiú-cuiús, bacus, botoados, armados, or rebecas (Brazil); and sierra or bagre hueso (Argentina, Bolivia, Colombia, Ecuador, Paraguay, Peru, Uruguay, Venezuela). They are readily distinguished among catfishes by having a single row of midlateral scutes, each usually with a single posteriorly oriented thorn. Vono \& Birindelli (2007) described aspects of the natural history of the monotypic Wertheimeria, and summarized published information on the ecology of other thorny catfishes. Quagio-Grassiotto et al. (2011) provided detailed descriptions and figures of sperm morphology in ten species of doradids.

The species of Auchenipteridae are popularly known as driftwood, zamora or slope-head catfishes (international community); carataí, fidalgo, mandubé, palmito, judeu, ximbé, cangati, or cachorro-de-padre (Brazil); and manduví, zamora, docella, or novia (Argentina, Bolivia, Colombia, Ecuador, Paraguay, Peru, Uruguay, Venezuela). They are readily distinguished among catfishes by exhibiting great sexual dimorphism, in which mature males have the anal fin modified for insemination. The ecology and biology of most auchenipterids are not well documented. Large-sized species of the genus Ageneiosus most likely undertake great reproductive migrations (Goulding, 1979, 1980). A few species of Pseudauchenipterus are relatively tolerant of saltwater, and have been collected on beaches near estuaries (Akama, 2004). Several species feed mainly on allochthonous items (e.g., Carvalho \& Resende, 1984), especially on insects that fall into the water at night.

During the nineteenth and twentieth centuries, many genera and species of Auchenipteridae and Doradidae were discovered and the classification of the species of both families changed many times. Nevertheless, during the last three decades, our understanding about the taxonomy and phylogenetic relationships of the species of Doradoidea has greatly improved. A review of the literature concerning the systematics of Doradoidea, and of each of its families, is presented below.

The goals of the present study are to provide evidence for the phylogenetic position of the Doradoidea within Siluriformes, to propose a hypothesis of phylogenetic relationships among genera of the Auchenipteridae and Doradidae, and to propose a new classification for Doradoidea.

Systematic history of the Doradoidea. In the tenth edition of the Systema Naturae, Linnaeus (1758: 304, 307) described two genera to accommodate 15 species of catfish: Silurus, with S. asotus, S. glanis, S. aspredo, S. mystus, S. anguillaris, S. batrachus, S. undecimalis, S. militaris, S. catus, S. clarias, S. ascita, S. costatus (=Platydoras costatus), S. callichthys, S. cataphractus (=Acanthodoras cataphractus), and the monotypic Loricaria, with $L$. cataphracta. In the same volume, Linnaeus (1758: 238) described another catfish, Acipenser plecostomus (=Hypostomus plecostomus, Loricariidae), among species of sturgeons (Acipenseridae). Eight years later, in the $12^{\text {th }}$ edition of the Systema Naturae, Linnaeus (1766: 508) described Silurus inermis (=Ageneiosus inermis), S. felis, S. galeatus (=Trachelyopterus galeatus), S. cous, S. carinatus (=Doras carinatus), S. fasciatus, S. bagre, and reallocated A. plecostomus to Loricaria. Although modern zoological nomenclature dates back to Linnaeus, his classification was based on Peter Artedi's (1738) Ichthyologiae (Jordan, 1917). From Linnaeus to the end of the $18^{\text {th }}$ century, only a few studies described species and genera of Siluriformes. The most meaningful additions to Doradoidea were: Cataphractus Edwards (for former Silurus callichthys, S. cataphractus, and S. costatus), and Silurus nodosus Bloch (=Pseudauchenipterus nodosus).

In the $19^{\text {th }}$ century, Bloch $\&$ Schneider (1801) proposed a classification that grouped all species of fishes that were then known into five classes. In one of the three orders of Octopterygii, they placed the species of Cataphractus and Loricaria among non-catfishes; and in one of the three orders of Heptapterygii, they placed Silurus and Platystacus. Lacepède (1803) described several genera of catfishes, including Doras and Ageneiosus. Lacepède (1803) assigned Silurus nodosus and S. galeatus in Pimelodus, S. costatus, and S. carinatus in Doras; Ageneiosus armatus (junior synonym of $S$. inermis) and $S$. inermis in Ageneiosus; and $S$. callichthys, Cataphractus americanus (junior synonym of S. cataphractus) and C. punctatus in Cataphractus.

Rafinesque (1815) was the first to allocate all species of catfish to an exclusive group, named by him as Ophlophoria (details in de Pinna, 1998). At almost the same time, Cuvier (1816, see also Cuvier, 1829, 1836-1849), placed all known catfishes in the "Siluroïdes", and diagnosed it based on detailed characters, most still used nowadays (de Pinna, 
1998). Cuvier (1816) considered Ageneiosus (including A. inermis and $A$. militaris), Doras (including $D$. americanus, $D$. carinatus, D. cataphractus, and D. costatus), as part of his "Siluroïdes". Other auchenipterids were allocated to Pimelodus and Silurus. Contrary to Edwards (in Casteby, 1771) and Bloch (1794), who allocated both doradids and callichthyids to Cataphractus, Cuvier (1816) recognized for the first time an exclusive group for doradids (Doras) and another for callichthyids (Callichthys).

Spix \& Agassiz (1829) studied the fishes collected by Spix in Brazil, and recognized within "Malacopterygii Abdominales", the families Gonyodontes for loricariids and Siluroidei for the remaining catfishes including Cetopsis, Doras, Hypophthalmus (including $H$. edentatus and $H$. nuchalis [= Auchenipterus nuchalis]), Pimelodus, Phractocephalus, Platystoma, and Heterobranchus.

Cuvier \& Valenciennes (1840) created a few more genera of catfishes, such as Arius for sea catfishes (which included the auchenipterid Silurus nodosus), Auchenipterus (which included A. nuchalis, A. dentatus, A. furcatus, A. trachycorystes, A. maculosus, A. immaculatus, and A. punctatus [all except the first described therein]), and Trachelyopterus (including T. coriaceus, also described as new). Cuvier \& Valenciennes (1840: 231) considered Ageneiosus (with A. militaris, A. inermis, and A. brevifilis) as related to Hypophthalmus; they noted the resemblance of the cephalic shield in Synodontis, Auchenipterus and Doras (Cuvier \& Valenciennes, 1840: 244); and they described several doradid species (D. armatulus, D. hancockii, $D$. dorsalis and $D$. niger), distinguishing $D$. carinatus and $D$. niger from the remaining species by having edentulous maxillae and compressed head (Cuvier \& Valenciennes, 1840: 288). Müller \& Troschel (in Müller, 1842a: 203) created Euanemus for E. colymbetes (=Auchenipterus dentatus), and reallocated S. nodosus to Auchenipterus.

Kner (1854), based on Heckel's manuscript about sexual dimorphism of Callichthys and gas bladders of Doras, illustrated the gas bladder in Doras polygramma (species inquirendae in Acanthodoras, Sabaj \& Ferraris, 2003), D. loricatus (= Ossancora. fimbriata), D. ophthalmus (= Anduzedoras oxyrhynchus), $D$. asterifrons, $D$. punctatus, $D$. brevis, D. armatulus, D. Hancoki (sic), and D. dorsalis, the first six proposed therein as new species. Two years later, Kner (1855) provided detailed descriptions of the species he had proposed earlier, in addition to other new catfish species and genera, including Oxydoras, $D$. fimbriatus (replacement name for $D$. loricatus), D. affinis, $D$. stenopeltis, $D$. humeralis, $D$. murica, D. dorbignyi, and D. heckelii. In 1858, Kner described Asterophysus batrachus, Centromochlus megalops, C. aulopygia, Auchenipterus thoracatus, and A. ceratophysus.

Contemporary to Kner was Bleeker, who despite having described few Neotropical species (relative to Indo-Pacific ones), created several new genera and suprageneric taxa of catfishes. His suite of papers (1858, 1862-1863, 1863a, 1863b, 1864) was summarized in the Systema Silurorum Revisum (Bleeker, 1863b). In his classification, the order "Siluri” was composed of seven subfamilies, including Trachelyopteriformes, with Trachelyopterini (composed of Trachelyopterus, Trachelyopterichthys), and Bagriformes, with Doradini (composed of Doras, Rhinodoras, Centrochir, Oxydoras, Lithodoras, Pterodoras, Platydoras, Acanthodoras, and Amblydoras), Pseudauchenipterini (composed of three phalanxes: Pseudauchenipteri, Centromochli, and Asterophysi), and Pangasini (composed of phalanx Pangasii, Ageneiosi [with Ageneiosus and Tetranematichthys], Auchenipterini [with Auchenipterus], Hypophthalmini, Heptapterini, and Argeini. Bleeker's classification is especially interesting within the framework of relationships of the Doradoidea for the: 1) placement of Doradini, Synodontini and Pseudauchenipterini close to each other; 2) placement of Ageneiosini and Auchenipterini close to each other and to Hypophthalmini, Pangasini and Heptapterini. 3) treatment of auchenipterids as "polyphyletic"; and 4) consideration of doradids as "monophyletic".

Another groundbreaking contribution to catfish classification was Günther's (1864) Catalogue of Fishes of the British Museum. Günther (1864) recognized as part of the "Siluridae Stenobranchiae": Doradina composed of Ageneiosus, Tetranematichthys, Euanemus, Auchenipterus, Centromochlus, Trachelyopterus, Cetopsis, Asterophysus, Doras, Oxydoras, Rhinodoras, and Synodontis; and, as such, he was the first to recognize doradids, auchenipterids and mochokids in the same group (albeit together with cetopsids).

In the last decades of the nineteenth century, several authors contributed papers more focused on species descriptions. An interesting example is Wertheimeria maculata, a doradid described by Steindachner (1877) and originally proposed as an auchenipterid.

Eigenmann's early studies with his wife Rosa Smith redefined the classification of Neotropical catfishes (Eigenmann \& Eigenmann, 1888, 1889, 1890, 1891); they considered doradids and auchenipterids as part of the family Siluridae composed of: Doradinae (Physopyxis, Doras, Oxydoras, and Hemidoras), Auchenipterinae (Asterophysus, Trachelyopterichthys, Wertheimeria, Centromochlus, Trachycorystes, Auchenipterichthys, Felichthys, Epapterus, Auchenipterus, and Tetranematichthys), and Ageneiosinae (Ageneiosus).

Bridge \& Haddon (1892) and Sörensen (1894-1895) were the first to offer well-supported morphological evidence of close relationships between doradids, auchenipterids, and mochokids: the presence of the elastic spring apparatus. Noteworthy, the elastic spring apparatus was first described by Müller (1842a, 1842b, 1843) for Auchenipterus, Doras, Synodontis, and Malapterurus, and subsequently for Pangasius by Bridge \& Haddon (1892).

Regan (1911: 556) described his views on the evolution of catfish families, and noted that Doradidae (including auchenipterids) and Ariidae may have evolved early, right after Diplomystidae, by being "generalized in form and in fin structure, but aberrant in the loss of the mesocoracoid". On the other hand, Regan (1911) also noted morphological resemblances between Doradidae (including auchenipterids) 
and mochokids, which he considered convergences, such as the restricted gill-openings, the expanded nuchal shield, and the elastic spring apparatus.

Miranda Ribeiro (1911) described Tatia and Mormyrostoma (=Doras, Sabaj Pérez \& Birindelli, 2008), reallocated Wertheimeria to Doradidae, which at that time included only doradids, and classified the auchenipterids into Trachycorystidae (Pseudauchenipterus, Glanidium, Centromochlus, Tatia, Asterophysus, Trachycorystes, Auchenipterichthys, Trachelyopterus, and Trachelyopterichthys), Auchenipteridae (Epapterus, Auchenipterus), and Ageneiosidae (Tetranematichthys, Ageneiosus, and Pseudageneiosus). Other researchers did not adopt Miranda Ribeiro's classification, and continued to follow the one previously established by Eigenmann \& Eigenmann (1891) (e.g., Eigenmann, 1925; Jordan, 1929; Berg, 1940; Gosline, 1945; Van der Stigchel, 1947; Fowler, 1951).

Chardon (1968) studied the Weberian apparatus and associated structures in catfishes, classifying the Doradidae, Auchenipteridae, Ageneiosidae, and Mochokidae in the superfamily Doradoidea within the suborder Bagroidei. He diagnosed Doradoidea (sensu Chardon, 1968) by having: 1) the general character of Bagroidei modified by the presence of the elastic spring apparatus, 2) strong cephalic shield, except in Ageneiosus, 3) nuchal shield sutured to parietalsupraoccipital through an écaille supplémentaire (=anterior nuchal plate), except in Ageneiosus, 4) posttemporalsupracleithrum sutured to cranium, 5) ligament or ossified process between epiotic and posterior ramus of the parapophysis of the fourth vertebra, and 6) deep groove in cleithrum in its articulation to the cranium. Those characters were re-examined by Britski (1972), who considered characters 2 and 6 to vary among doradids and auchenipterids, character 3 to be absent in several doradids and auchenipterids, and character 5 incorrect because doradids and auchenipterids lack the posterior ramus of the parapophysis of the fourth vertebra. Britski (1972) concluded that there was no support for a close relationship between the African Mochokidae and the three Neotropical families, Ageneiosidae, Auchenipteridae, and Doradidae.

In the 1980's, with the development of the cladistic method, and the beginning of a new paradigm in Systematics, several studies focused on catfish relationships were performed. Royero (1987) studied the anatomy of the dorsal fin in catfishes, and considered Ariidae related to Ageneiosidae, Auchenipteridae, Doradidae and Mochokidae. One year later, Ferraris (1988) performed a phylogenetic analysis including most auchenipterid and a few doradid genera. His results supported a new classification for auchenipterids in which Ageneiosus and Tetranematichthys were nested within the Auchenipteridae. Ferraris (1988) divided auchenipterids into two families: Centromochlidae (with Centromochlus, Gelanoglanis, Glanidium, and Tatia), and Auchenipteridae (including Ageneiosus and Tetranematichthys).

Mo (1991), in a study focused on the Bagridae, proposed a hypothesis for the phylogenetic relationships of most catfish families. His analysis incorporated additional characters and corroborated Royero's (1987) previous hypothesis of a close relationship among Ariidae, Auchenipteridae, Doradidae, and Mochokidae. The first comprehensive cladistic analysis including all known families of catfishes was performed by de Pinna (1993), who considered Mochokidae related to Auchenipteridae plus Doradidae, and these three not closely related to Ariidae. In that same year, Lundberg (1993) illustrated the undescribed fossil catfish "Titanoglanis" and discussed its relationships with Ariidae, Auchenipteridae, Doradidae, and Mochokidae.

Friel (1994) studied the Neotropical family Aspredinidae, and proposed its close relationship to Auchenipteridae, Doradidae, and Mochokidae based on a cladistic analysis of morphological data. Subsequently, de Pinna (1996) considered Aspredinidae related to Asian-endemic Amblycipitidae, Akysidae, Sisoridae, and Erethistidae, based on a comprehensive cladistic analysis of those families. De Pinna (1998) summarized what was then known on catfish relationships, establishing the suborder Doradoidei for Doradoidea plus Mochokidae (considered related to Ariidae). The Doradoidea of de Pinna (1998) includes the Doradidae plus Auchenipteridae (including Centromochlidae).

Royero (1999), focusing on auchenipterids but including in his analyses other catfishes, corroborated his previous phylogenetic hypothesis: Ariidae (Mochokidae (Doradidae, Auchenipteridae)). Britto (2002), re-evaluating all aforementioned phylogenetic hypotheses and morphological evidences for those relationships, concluded that Ariidae were not closely related to the Doradoidea plus Mochokidae. Diogo (2004), in a cladistic analysis including all catfish families, proposed the Doradoidea plus Mochokidae as sister group of Malapteruridae.

More recently, with the development of DNA sequence data as a source of characters for phylogenetic analysis, Sullivan et al. (2006, 2008) recovered a strong molecular support for Aspredinidae as sister to Doradidae plus Auchenipteridae, with Mochokidae more closely related to other African catfishes, and Ariidae (plus Anchariidae) in an unresolved polytomy with several other catfish families.

In conclusion, both morphological and molecular data strongly support Doradidae and Auchenipteridae as sistergroup families in the superfamily Doradoidea. However, the relationships between Doradoidea and other families of catfishes are still unresolved. Historically, Doradoidea has been considered most closely related to: 1) Mochokidae and Malapteruridae (based on the presence of the elastic spring apparatus), 2) Mochokidae and Ariidae (based on features of the nuchal shield), 3) Mochokidae and Aspredinidae (based on features of the pectoral girdle), and 4) Aspredinidae (based on molecular data).

Systematic history of the Doradidae. Doradid taxonomy begins with Linnaeus $(1758,1766)$, who described Silurus costatus, S. cataphractus, and S. carinatus. The first doradid genus described was Cataphractus Edwards in Casteby, 1771 
(type species S. cataphractus by tautonomy). However, it is considered a nomen oblitum, and as such, a junior synonym of Acanthodoras (Sabaj \& Ferraris, 2003; Ferraris, 2007; Eschmeyer, 2014).

Lacepède (1803) created the genus Doras, in which most doradid species were described until the second half of the nineteenth century, when Kner $(1854,1855)$ described Oxydoras, as a subgenus, to allocate species with a compressed head. Following that classification of species (i.e., caput elevatum vs. caput depressum), Bleeker $(1858,1862-$ 1863, 1863a, 1863b, 1864) described several additional genera.

In one of his last papers, Eigenmann (1925) presented an exhaustive taxonomic revision of the Doradidae, diagnosing the family and its taxa based on detailed morphological characters. He allocated all known valid species (68 total) into 26 genera. Following previous authors, Eigenmann (1925) considered the family to be divided into species with a depressed head, wide pectoral girdle, premaxilla with several rows of teeth and simple barbels, vs. species with a compressed head and pectoral girdle, snout sometimes elongate, premaxilla reduced in size, few or no teeth, and barbels usually branched. More than 40 years later, Fernández-Yépez (1968) published a partial revision focused on Venezuelan doradids. Regionally limited, Fernández-Yépez’s $(1950,1968)$ studies included various taxonomic mistakes and most of the taxa he described were subsequently found to be junior synonyms.

Higuchi (1992) performed the first phylogenetic analysis of doradids using the cladistic method (Fig. 1a). His results, which were based on morphology, considered doradids to be composed of Wertheimeria, Franciscodoras and three subfamilies of unresolved relationships. Subsequently, Higuchi et al. (2007) described Astrodoradinae for Astrodoras, Amblydoras, Anadoras, Hypodoras, Merodoras, Physopyxis, and Scorpiodoras. Moyer et al. (2004) studied the phylogenetic relationships of doradids based on molecular data (Fig. 1b). Their results were only partially congruent with Higuchi's and were possibly misled by a lack of some relevant basal taxa in the Doradidae (i.e., Wertheimeria, Kalyptodoras, and Franciscodoras).

More recently, Birindelli et al. (2009) studied the morphology of the gas bladder in 92 species of Doradidae, finding modifications associated with the presence of diverticula, additional bladders, inner septa, among other features. Sousa (2010) completed the taxonomic revision and phylogenetic analysis of 21 species included in the subfamily Astrodoradinae. Quagio-Grassioto et al. (2011) studied the morphology of the sperm in 10 species of the Doradidae, finding distinct type of spermatogenesis, spermiogenesis and spermatozoa correlated with intrafamilial groups of Doradidae. Arce et al. (2013) performed a comprehensive phylogenetic analysis based on molecular data for 86 species of Doradidae, using both nuclear and mitochondrial gene sequences.

Sabaj (2002) and Sabaj \& Ferraris (2003) compiled monographic data for all nominal doradids and resolved a number of taxonomic issues; their classification recognized 72 valid species in 30 genera. Since then, the taxonomic knowledge of the family has greatly increased. Sousa \& Rapp Py-Daniel (2005) revised Physopyxis, describing two new species. Sabaj (2005) revised Leptodoras, describing three species as new. Two years later, Birindelli et al. (2007) described Rhynchodoras castilloi from Venezuela; Higuchi et al. (2007) described a new genus and species, Merodoras nheco; and Sabaj Pérez et al. (2007) described †Doras dionae, the only named fossil species. In 2008, Sabaj et al. (2008) described two new species of Rhinodoras; Sabaj Pérez \& Birindelli (2008) revised Doras, describing three species as new; Birindelli et al. (2008) described Leptodoras oyakawai; and Piorski et al. (2008) described Platydoras brachylecis and revalidated $P$. hancockii. Two years later, Birindelli \& Sousa (2010) described Leptodoras marki. In 2011, Sousa \& Birindelli (2011) described Scorpiodoras liophysus, and revalidated S. calderonensis; Birindelli \& Sabaj-Pérez (2011) described the new genus Ossancora with $O$. asterophysa as a new species; and Birindelli et al. (2011) described Hassar gabiru as new species from the middle and upper rio Xingu. Last year, Sabaj-Pérez \& Birindelli (2013) described Hassar shewellkeimi from the upper rio Tapajós. In less than eight years, those recently published papers have increased by approximately $30 \%$ the total number of species of the Doradidae, which currently comprises 93 valid species (92 extant plus one fossil), arranged in 31 genera.

Systematic history of the Auchenipteridae. The systematics of Auchenipteridae begins with Linnaeus (1766) through the description of Silurus inermis and S. galeatus. Soon thereafter, Bloch (1794) described Silurus nodosus. Lacepède (1803) described Ageneiosus for Silurus inermis, and allocated

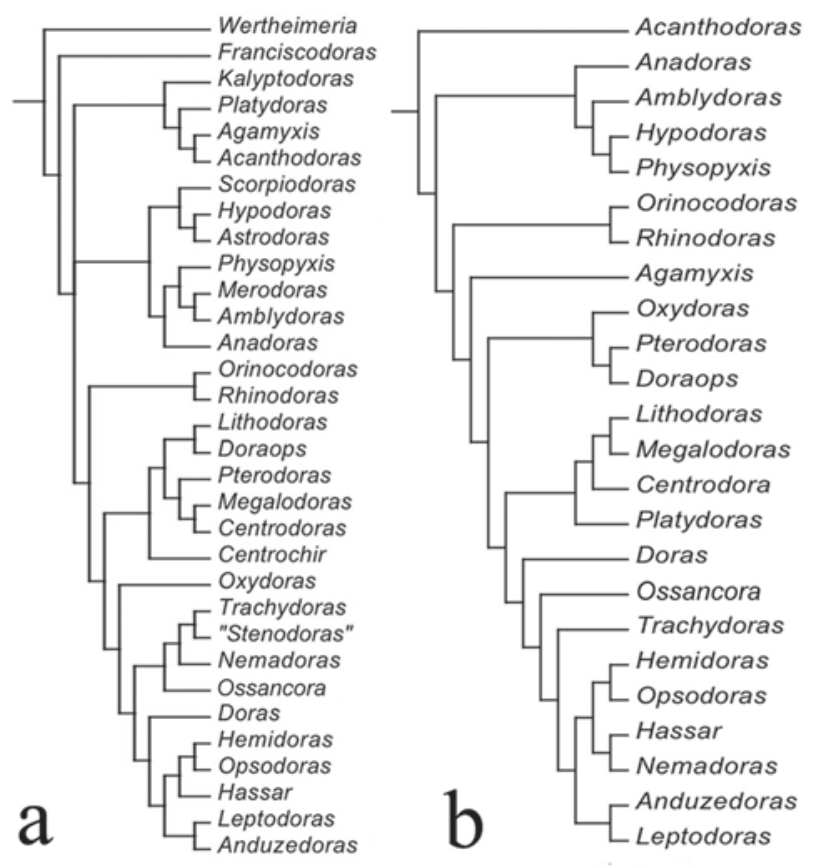

Fig. 1. Phylogenetic relationships of Doradidae, according to the hypotheses of (a) Higuchi (1992), and (b) Moyer et al. (2004). 
Silurus galeatus and S. nodosus to Pimelodus. Spix \& Agassiz (1829) described Hypophthalmus nuchalis (= Auchenipterus nuchalis). Few years later, Valenciennes in Cuvier \& Valenciennes (1840) described Auchenipterus for A. nuchalis, and Trachelyopterus for $T$. coriaceus, while also naming six new species.

In late nineteenth and early twentieth centuries, several authors described species and/or genera that are currently classified in Auchenipteridae (e.g., Jardine, 1841; Castelnau, 1855; Kner, 1858; Bleeker, 1858, 1864; Lütken, 1874; Cope, 1878; Steindachner, 1880, 1910, 1915; Eigenmann \& Eigenmann, 1888; Miranda Ribeiro, 1918). At that time, those species and genera were allocated to different groups within Siluriformes, including the Neotropical pimelodids Hypophthalmus and Pimelodus, and the Asian family Pangasiidae. Günther (1864) was the first to assemble all species of auchenipterids, and grouped them with doradids, cetopsids and mochokids. Eigenmann \& Eigenmann (1888) were the first to classify auchenipterids known at that time in two exclusive families: Auchenipteridae and Ageneiosidae.

Ihering (1937) diagnosed the Auchenipteridae by the presence of a pseudopenis, distinguishing it from Ageneiosidae and Doradidae, and considered it to be composed of Auchenipterinae and Trachycorystinae. The classification of Ihering, however, was not followed by subsequent researchers (e.g., Gosline, 1945; Fowler, 1951; Chardon, 1968).

Miranda Ribeiro (1968a, 1968b, 1968c) classified auchenipterids into five families based on characters related to sexual dimorphism: Ageneiosidae (Ageneiosus,
Tympanopleura), Auchenipteridae (Auchenipterus, Epapterus, and Pseudepapterus), Trachycorystidae (Auchenipterichthys, Tetranematichthys, and Trachycorystes), Centromochlidae (Centromochlus, Glanidium, Entomocorus, Pseudauchenipterus, and Tatia), and Asterophysidae (Asterophysus).

Britski (1972) revised the genera of Auchenipteridae, proposed an evolutionary scheme for them (Fig. 2a), and concluded that the Ageneiosidae and Auchenipteridae are sister-families related to the Doradidae. Britski (1972) diagnosed Auchenipteridae plus Ageneiosidae by the presence of sexually dimorphic features, such as the modified anal fin in mature males. Apparently unaware of Britski's study, Mees (1974) also revised the Auchenipteridae, based mainly on specimens collected in Suriname, and also rejected the classification of Miranda Ribeiro.

Ferraris (1988) performed a comprehensive cladistic analysis of the Auchenipteridae, in which he concluded that Ageneiosus and Tetranematichthys were deeply nested within the Auchenipteridae, and that the Centromochlidae (with Centromochlus, Gelanoglanis, Glanidium, and Tatia) was a distinct family (Fig. 2b). One year later, Curran (1989) published a hypothesis of relationships for few species of auchenipterids based on limited characters that was largely incongruent with other studies (Fig. 2c).

Walsh (1990) studied the taxonomy and phylogeny of Ageneiosus and Tetranematichthys (both formerly included in the Ageneiosidae). Soares-Porto (1998) published a paper on the phylogenetic relationships of species of the Centromochlinae. One year later, Royero (1999) performed a
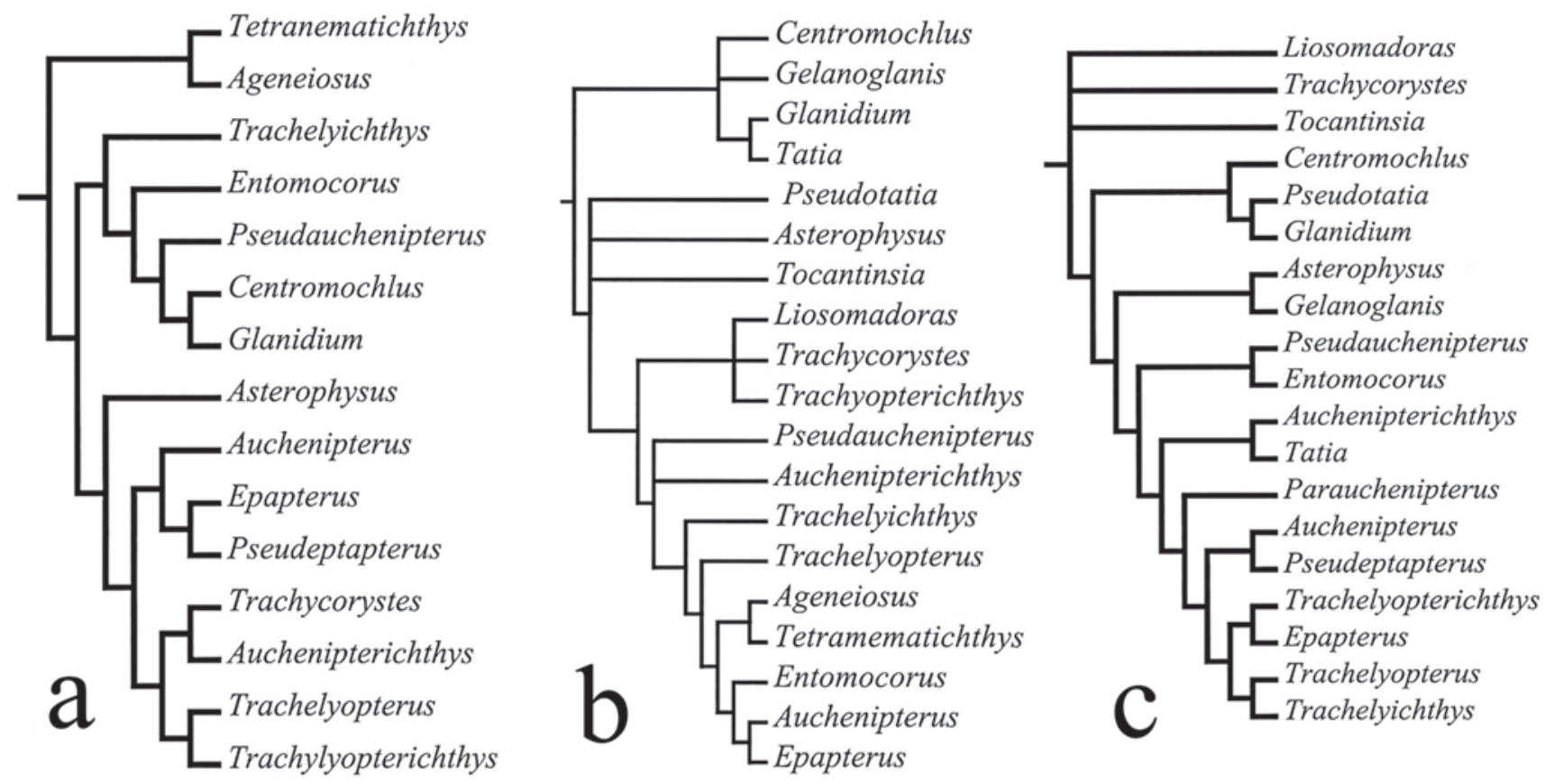

Fig. 2. Phylogenetic relationships of Auchenipteridae, according to the hypotheses of (a) Britski (1972), (b) Ferraris (1988), and (c) Curran (1989). 
phylogenetic analysis of most genera of Auchenipteridae. Recently, in order to establish the phylogenetic position of Trachelyopterus, Akama (2004) performed another phylogenetic study including most auchenipterid genera. Sarmento-Soares \& Porto (2006) presented a study on the comparative anatomy of the cheek muscles in Centromochlinae. Ribeiro (2011) revised Ageneiosus and proposed a phylogenetic hypothesis for its species, including in the analysis most genera of Auchenipteridae. And finally, Birindelli et al. (2012) described and discussed the evolution of the morphology of the gas bladder in most species of the Auchenipteridae. There are several incongruences between results obtained in all these studies.

As for doradids, the taxonomy of auchenipterids has greatly improved in recent years. From 1998 to 2000, Vari \& Ferraris (1998) revised Epapterus, recognizing two valid species; Ferraris \& Vari (1999) revised Auchenipterus, describing two new species; Soares-Porto et al. (1999) described Gelanoglanis nanonocticolus; Soares-Porto (2000) described Centromochlus macracanthus; and Ferraris \& Vari (2000) described Pseudepapterus gracilis as a new species from the Caura River in Venezuela. Later on, Akama \& Ferraris (2003) described Entomocorus malaphareus as a new species from the Amazon; Sarmento-Soares \& Buckup (2005) described Glanidium bockmanni; and Ferraris et al. (2005) revised Auchenipterichthys, currently with three valid species. In 2006, Reis \& Borges (2006) revised Entomocorus, describing one new species from the Pantanal; and Vari \& Ferraris (2006) described Tetranematichthys wallacei. Two years later, Sarmento-Soares \& Martins-Pinheiro (2008) revised Tatia, describing three new species; and Rengifo et al. (2008) described Gelanoglanis travieso from the Marañon River in Peru. In the following year, Pavanelli \& Bifi (2009) described Tatia jaracatia from rio Iguaçu in Brazil. In 2010, Peixoto \& Wosiacki (2010) described Tetranematichthys barthemi; and Ribeiro \& Rapp Py-Daniel (2010) described Ageneiosus uranophthalmus. Britski \& Akama (2011) described Trachycorystes menezesi from the rio Aripuanã, in Brazil; and Akama \& Ferraris (2011) described Spinipterus acsi as a new genus and species. Birindelli \& Zuanon (2012) revised Liosomadoras, redescribing $L$. morrowi and $L$. oncinus. Last year, Sarmento-Soares \& Martins-Pinheiro (2013) described Glanidium botocudo; Vari \& Ferraris (2013) described two new species of Tatia; and Sarmento-Soares et al. (2013) described Centromochlus meridionalis. The family Auchenipteridae now comprises 108 valid species arranged in 21 genera.

\section{Material and Methods}

Anatomical and taxonomic nomenclature. Nomenclature for muscles follows Winterbottom (1974). Nomenclature for cranial nerves follows Freihofer (1978). Osteological nomenclature according to Weitzman (1962) with the following exceptions (all detailed in the Teleostei Anatomy Ontology website at http://bioportal.bioontology.org/ontologies/TAO): anguloarticular (fusion of angular, articular and retroarticular bones) replaces separate articular and angular; anterior and posterior ceratohyal replaces ceratohyal and epihyal, respectively; autopalatine replaces palatine; basipterygium replaces pelvic bone; entopterygoid (= tendon-bone entopterygoid) replaces mesopterygoid; mesethmoid replaces ethmoid; vomer replaces prevomer; parietal-supraoccipital replaces separate parietal and supraoccipital; posttemporalsupracleithrum replaces separate posttemporal and supracleithrum; and pharyngobranchial replaces suspensory pharyngeal. The first bone of the infraorbital series is herein referred to as infraorbital 1 (replaces lacrimal of Birindelli et al. 2007). It is formed from a single ossification (Birindelli, 2010), and includes the antorbital and infraorbital branches of the infraorbital canal. Some authors (e.g., Arratia \& Huaquín, 1995) have considered this bone homologous with the antorbital of Characiformes, which does not bear a canal (Weitzman, 1962). For the small cartilage articulating with epibranchials 1 and 2 and pharyngobranchial 3 the term pharyngobranchial accessory cartilage is used (Birindelli \& Sabaj-Pérez, 2011). This structure is also referred to as accessory cartilaginous nodule (Bockmann \& Miquelarena, 2008: 22), and incorrectly as pharyngobranchial 1 and/or 2 (Higuchi, 1992; Birindelli et al., 2008). The term accessory element of ceratobranchial 4 is used for the small cartilage associated to ceratobranchial 4, instead of epibrancuial 5 (as in Birindelli et al., 2011), following Carvalho et al. (2013). Gas bladder terminology follows Birindelli et al. (2009). Abbreviations include “\#” for character number, and SL for Standard Length.

Taxonomic nomenclature follows the most recent classification of the Siluriformes as summarized by Ferraris (2007), Eschmeyer (2014) and Lundberg et al. (2014), and includes Doradoidea (=Doradidae plus Auchenipteridae), Sisoroidea (=Amblycipitidae plus Akysidae, Erethistidae, and Sisoridae), Loricarioidei (=Loricariidae plus Astroblepidae, Callichthyidae, Nematogenyidae, Scoloplacidae, and Trichomycteridae), and Siluroidei [=Siluriformes except Loricarioidei and Diplomystoidei (=Diplomystidae)]. Doradoidei sensu de Pinna (1998) (=Doradidae plus Auchenipteridae and Mochokidae) is not used because the three families of this group are included in a larger suborder of Siluriformes (Siluroidei).

The new names and arrangements used throughout the text include: Tenellus, new genus, comprising taxa formerly treated as Nemadoras trimaculatus (type-species), $N$. leporhinus, and N. ternetzi (sensu Sabaj \& Ferraris, 2003; Ferraris, 2007; Arce et al., 2013; Eschmeyer, 2014); Hemidoras inclusive of Hemidoras morrisi, H. stenopeltis, H. morei, $H$. boulengeri and $H$. stubelii, the last three as new combinations (previously allocated to Opsodoras by Sabaj \& Ferraris, 2003; Ferraris, 2007; Eschmeyer, 2014); Astrodoradinae inclusive of Astrodoras, Anadoras, Amblydoras, Physopyxis, Hypodoras, and Scorpiodoras (sensu Higuchi et al., 2007 and Arce et al., 2013); Wertheimerinae, new subfamily, inclusive of Kalyptodoras and Wertheimeria; Doradinae, new 
arrangement, inclusive of fimbriate-barbel doradids plus Centrodoras, Centrochir, Doraops, Lithodoras, Megalodoras, Orinocodoras, Oxydoras, Platydoras, Pterodoras, Rhinodoras, and Rhynchodoras; fimbriate-barbel doradids meaning Anduzedoras, Doras, Hassar, Hemidoras, Leptodoras, Nemadoras, Ossancora, Tenellus, and Trachydoras. The genera Acanthodoras, Agamyxis, and Franciscodoras were considered as incertae sedis in Doradidae, due to the presence of disputing hypotheses of phylogenetic position (Higuchi, 1992; Moyer et al., 2004; Higuchi et al., 2007; Arce et al., 2013).

Material examined and taxa selection. Observations were based on museum specimens preserved in alcohol (for myology and viscera), and prepared as clear and stained specimens (following methods of Taylor \& Van Dyke, 1985), or as dry skeletons (following methods of Bemis et al., 2004). Museum abbreviations are: AMNH, American Museum of Natural History, New York; ANSP, Academy of Natural Sciences of Drexel University, Philadelphia; AUM, Auburn University Natural History Museum, Auburn; BMNH, Natural History Museum, London; CAS, California Academy of Sciences, San Francisco; CAS-SU, CAS specimens received from Stanford University; CU, Cornell University Museum of Vertebrates, Ithaca; FMNH, Field Museum of Natural History, Chicago; INHS, Illinois Natural History Survey, Champaign; INPA, Instituto Nacional de Pesquisas da Amazônia, Manaus; MCP, Museu de Ciências e Tecnologia da Pontifícia Universidade Católica do Rio Grande do Sul, Porto Alegre; MCNG, Museo de Ciencias Naturales de UNELLEZ, Guanare; MCZ, Museum of Comparative Zoology, Harvard University, Cambridge; MHNLS, Museo de Historia Natural La Salle, Fundación La Salle de Ciencias Naturales, Caracas; MNHN, Muséum National d'Histoire Naturelle, Paris; MZUEL, Museu de Zoologia da Universidade Estadual de Londrina; MZUSP, Museu de Zoologia da Universidade de São Paulo, São Paulo; NUP, Coleção Ictiológica do Núcleo de Pesquisas em Limnologia, Ictiologia e Aquicultura, Universidade Estadual de Maringá, Maringá; ROM, Royal Ontario Museum, Department of Natural History, Toronto; SMF, Senckenberg Forschungsinstitut und Naturmuseum, Frankfurt; UMMZ, University of Michigan Museum of Zoology, Ann Arbor; USNM, National Museum of Natural History, Smithsonian Institution, Washington D.C.; ZMS, Zoologische Staatssammlung München, Munich.

A total of 100 terminal taxa were included in the phylogenetic analysis. Criteria for selecting terminals included: previous studies identifying taxon as occupying a basal position within its family (or genus), unspecialized taxa (i.e., with few modifications), and taxa well represented in museum collections.

Most species of Doradidae were included (57 of 93 valid species). The taxa omitted were: Rhinodoras armbrusteri and $R$. gallagheri, both recently described by Sabaj et al. (2007) and very similar to $R$. boehlkei; Rhynchodoras xingui, rare in collections (Birindelli et al., 2007); Oxydoras sifontesi, similar to Oxydoras niger; $†$ Doras dionae, a fossil species recently diagnosed by Sabaj-Pérez et al. (2007) on the basis of a partial pectoral girdle; Doras micropoeus and D. zuanoni, two of the five valid extant species of Doras, recently revised by Sabaj Pérez \& Birindelli (2008); Hassar shewellkeimi and $H$. wilderi, two of the five valid species of Hassar, also recently revised (Birindelli et al., 2011; Sabaj-Pérez \& Birindelli, 2013); eight of the 12 species of Leptodoras, also recently revised (Sabaj, 2005; Birindelli et al., 2008; Birindelli \& Sousa, 2010); Acanthodoras depressus and A. spinosissimus, two of three species of the genus, in need of a taxonomic revision; Agamyxis pectinifrons, one of two species of Agamyxis, recently revised (Sousa, 2010); and all Astrodoradinae, except Astrodoras asterifrons, Scorpiodoras heckelii, and Anadoras grypus, a subfamily under study by Leandro Sousa (UFPA) (see Sousa, 2010 for unpublished results). On the other hand, an intriguing undescribed species of Platydoras was included because it possesses characters of both Platydoras (color pattern) and Centrochir (gas bladder morphology, see Birindelli et al., 2009).

Twenty-three species of Auchenipteridae were included: one species of each genus, except for Ageneiosus and Trachelyopterus, diverse genera from which two species were included: Ageneiosus atronasus, A. inermis, Trachelyopterus coriaceus, and T. galeatus. The monotypic Spinipterus acsi, recently described and known from a single maturing male, was included based exclusively on information provided by Akama \& Ferraris (2011).

To determine the position of the Doradoidea within Siluriformes, at least one representative species was included for each of the following 16 families of catfishes: Diplomystidae, Nematogenyidae, Ictaluridae, Amphiliidae, Pimelodidae, Pseudopimelodidae, Heptapteridae, Siluridae, Claroteidae, Pangasiidae, Malapteruridae, Erethistidae, Sisoridae, Aspredinidae, Ariidae, and Mochokidae. The choice of these families was based on previous phylogenetic hypotheses based on morphological and molecular characters (de Pinna, 1998; Britto, 2002; Diogo, 2004; Sullivan et al., 2006, 2008). According to these studies, the selected families are possibly closely related to Doradoidea or relatively basal in other family groups of Siluriformes. Additional species of Mochokidae and Ariidae, two families previously considered to be closely related to Doradoidea by many authors (see Introduction), were included in the analyses: Galeichthys peruvianus and Genidens genidens, one taxon representative of each Galeichthyinae and Ariinae, respectively (sensu Marceniuk et al., 2012), and Chiloglanis disneyi, Mochokiella paynei, Mochokus niloticus, and Synodontis schall, taxa representative of the major lineages of Mochokidae (sensu Vigliotta, 2008).

Phylogenetic analysis. Phylogenetic hypotheses were obtained using the cladistic method, originally proposed by Hennig $(1950,1966)$. The Diplomystidae was chosen as the rooting point because it is considered the sister-taxon of all remaining Siluriformes based on morphology, or of all non- 
loricarioid catfishes (i.e., the Siluroidei) based on molecular evidence. Alternative use of Nematogenys (a loricarioid catfish) as tree root yields the same relationships for Doradoidea and close-related families. Multistate characters were treated as ordered whenever they showed morphoclinal variation, inferred according to the similarities of each state or, when available, to the sequence in ontogenetic series of development. The character matrix was edited using MacClade, version 4.08 (Maddison \& Maddison, 2005), and the parsimony analysis performed using TNT (Goloboff et al., 2008). Heuristic search (=Tradicional search) using TreeBisection-Reconnection (TBR) was applied, with 10.000 replicates, saving 10 trees per replication. A strict consensus tree was calculated using all fundamental, most parsimonious, trees obtained. Characters were numbered starting from character \#0, following the default of TNT and WinClada. Character state changes were optimized in the consensus tree using WinClada (Nixon, 1999-2002). Ambiguous synapomorphies in the consensus tree were optimized under ACCTRAN, whereby reversals are preferred over convergences, thus maximally preserving hypotheses of primary homology (de Pinna, 1991). Bremer support (Bremer, 1994) of each branch was calculated using the TBR algorithm in TNT. Consistency (CI) and Retention (RI) indices of fundamental cladograms and characters (on fundamental trees) were also calculated using TNT, through the scripts 'wstats' and 'stats'. Characters were coded as inapplicable if comprised a characteristic that could not be determined in the taxon even though there were specimens available for examination (e.g., shape of anterior nuchal plate in taxa that lack anterior nuchal plate); or as missing data, if there were not available specimens to be examined or if the character comprised a structure that was damaged in the examined specimens (e.g., dimorphic features in species from which the only known specimens are immature males and females); both cases coded as “?” in the matrix.

\section{Results and Discussion}

\section{Character descriptions.}

\section{External morphology.}

0. Coloration of head and body: 0- tan or brown background color, uniform or covered by dark or pale (faint white in life) blotches and/or stripes; 1- black background and conspicuous pale (yellow in life) blotches and/or stripes (CI 0.333, RI 0.5).

The doradids Acanthodoras, Agamyxis, Doras zuanoni, Orinocodoras eigenmanni, and Platydoras (except $P$. costatus) have a very distinct coloration of head and body, consisting of black background with pale conspicuous blotches and/or stripes (yellow in life) (Fig. 3). This color pattern is related to the elaborate behavior of cleaning fishes in Platydoras armatulus (Carvalho et al., 2003), and possibly also in the others. All other examined species have pale or brown background color, uniform or covered by dark or pale (faint white in life) blotches and/or stripes.

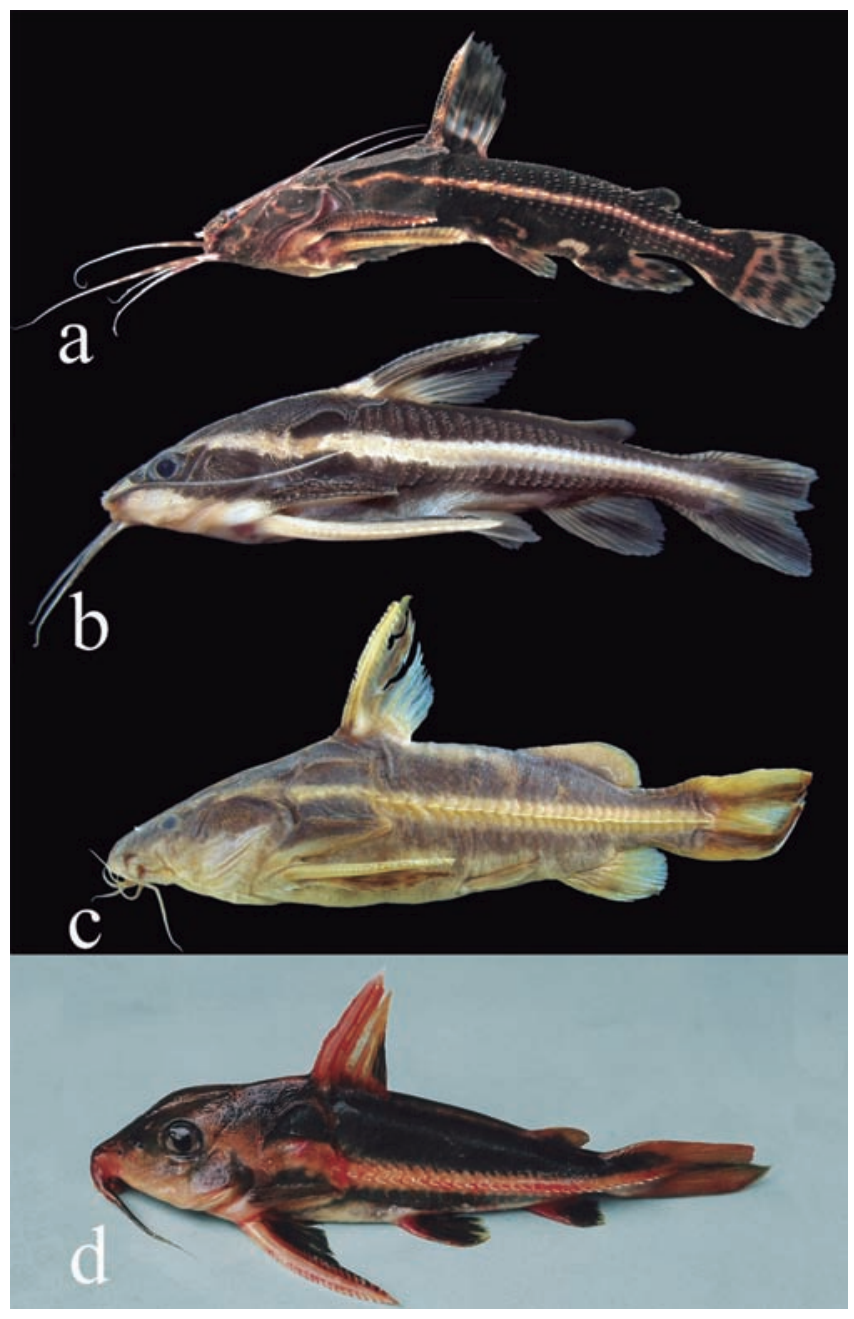

Fig. 3. (a) Acanthodoras cataphractus, MZUSP 103284, 76.6 mm SL, rio Jari, Monte Dourado, Pará, photographed live; (b) Platydoras armatulus, MZUSP 92759, approximately 55 mm SL, rio Amazonas, Santarém, Pará, photographed live by Leandro Sousa; (c) Orinocodoras eigenmanni, MZUSP 86807, 123 mm SL, río Apure, Arismendi, Venezuela; (d) Doras zuanoni, INPA uncatalogued, approximately $110 \mathrm{~mm}$ SL, rio Araguaia basin, photographed live by Jansen Zuanon.

1. Coloration on caudal-fin lobes: 0 - uniform; 1 - with a distinct dark longitudinal stripe on middle of each lobe (CI 0.167, RI 0.5).

In the doradids Anadoras, Centrochir, Orinocodoras, Platydoras, Tenellus, and Leptodoras (except L. myersi and L. juruensis), there is a conspicuous dark stripe on the middle of each caudal-fin lobe (Fig. 4b-d; Sousa, 2010: \#7). The caudal-fin lobes are uniformly colored in all other examined species (Fig. 4a).

2. Adipose eyelid: 0- weakly developed, horizontal adipose eye diameter larger than horizontal diameter of eye by less than 10\% (AED and ED of Sabaj, 2005, respectively); 1- well developed, horizontal adipose eye diameter larger than horizontal diameter of eye by $10 \%$ or more (CI 0.5, RI 0.889 ). 


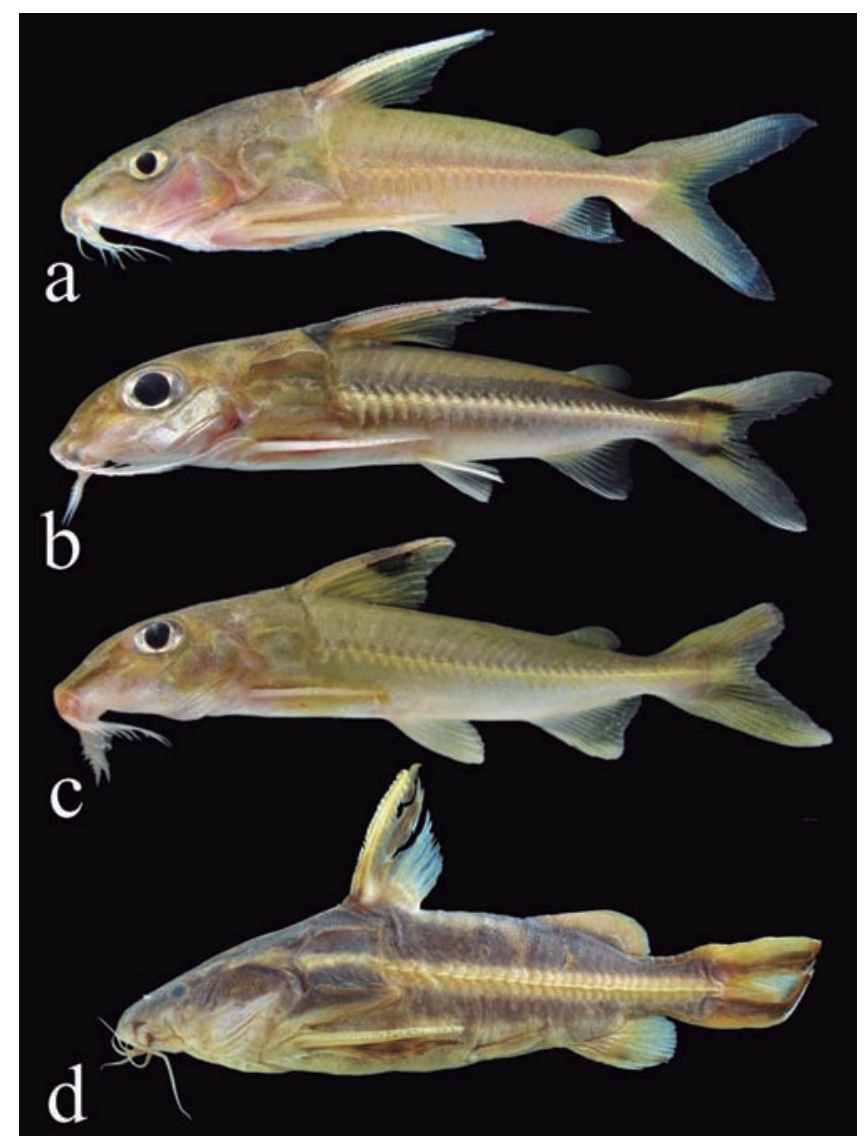

Fig. 4. (a) Nemadoras humeralis, INPA uncatalogued, rio Solimões, Manaus, Amazonas, photographed live by Leandro Sousa; (b) Tenellus ternetzi, MZUSP 103245, 84.5 mm SL, rio Jari, Monte Dourado, Pará, photographed live; (c) Leptodoras marki, MZUSP 103217, 80.3 mm SL, rio Fresco, São Felix do Xingu, Pará, photographed live; (d) Orinocodoras eigenmanni, MZUSP 86807, 123 mm SL, río Apure, Arismendi, Venezuela.

The eye is bordered by a weakly developed adipose eyelid in most catfishes, with horizontal adipose eye diameter larger than horizontal diameter of eye by less than $10 \%$ (Fig. 2a,b). However, the doradids Anduzedoras, Hassar, Tenellus, and most basal species of Leptodoras, including $L$. copei, $L$. hasemani, L. marki, L. oyakawai, and L. praelongus, have well-developed adipose eyelid, with horizontal adipose eye diameter larger than horizontal diameter of eye by $10 \%$ or more (Fig. 5c; Sabaj, 2002: \#7).

3. Posterolateral lobe on lips: 0- absent; 1- present (CI 1.0, RI 1.0).

The lips of the doradids Orinocodoras and Rhinodoras are thick and bear posterolaterally-directed lobes at the lateral corners of the mouth (Fig. 6a), rendering those taxa with the informal name of thick-lip thorny cat (Sabaj et al., 2008). All other examined species lack a posterolateral lobe on lips (Fig. $6 b)$.

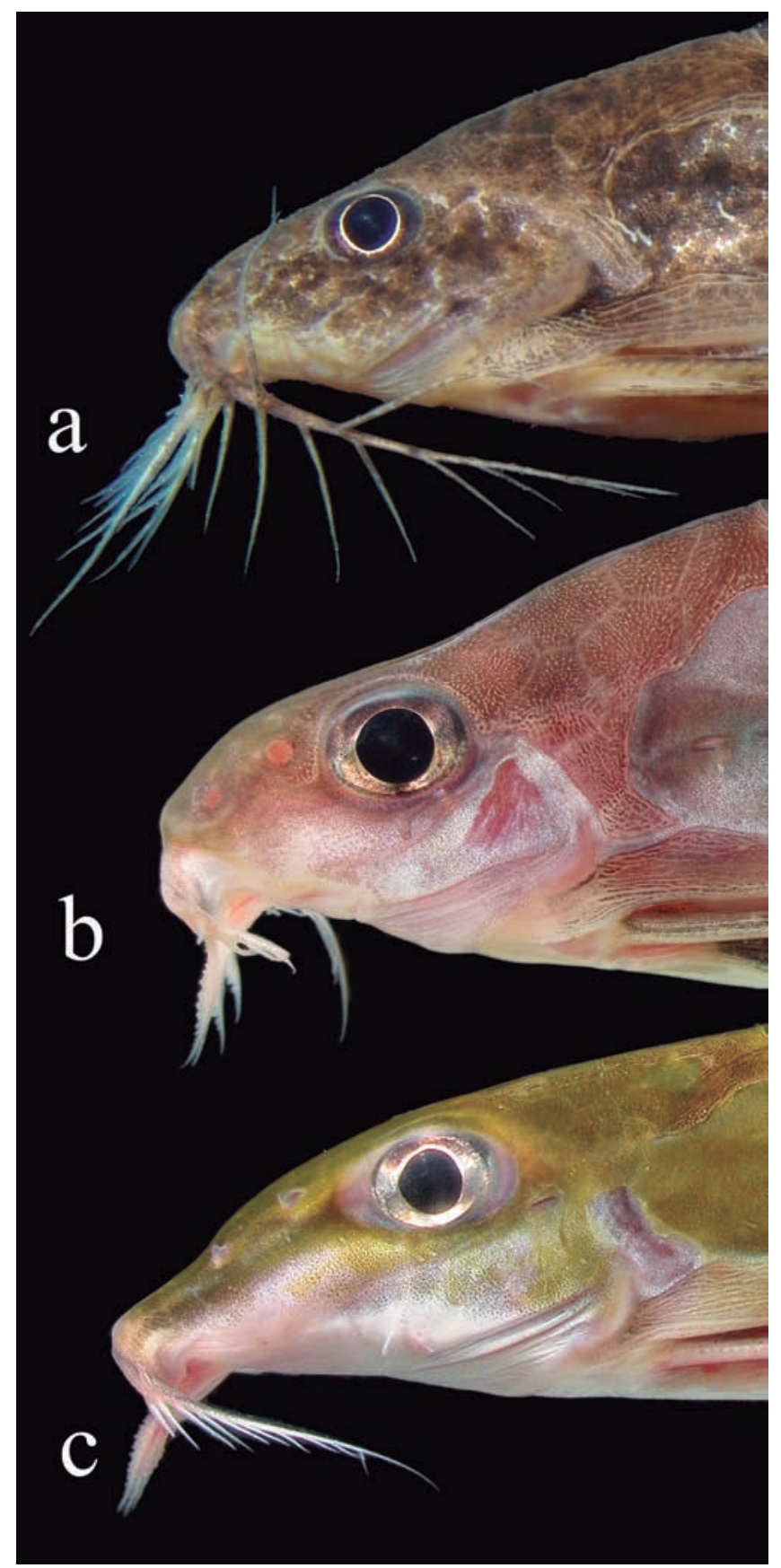

Fig. 5. Head, in lateral view, of (a) Ossancora asterophysa, MZUSP 92783, approximately $60 \mathrm{~mm}$ SL, photographed live by Leandro Sousa; (b) Trachydoras brevis, MZUSP 103087, approximately $70 \mathrm{~mm}$ SL, photographed live; (c) Hassar orestis, MZUSP 103327, 104 mm SL, photographed live.

\section{Adipose fin: 0- present; 1- absent (CI 0.143, RI 0.0).}

The adipose fin is present in most catfishes. However, it is absent in the Aspredinidae, Nematogenyidae, Siluridae, auchenipterids Epapterus, Trachelyichthys, Trachelyopterichthys, Trachelyopterus coriaceus (Ferraris, 1988: \#O2; Curran, 1989: \#12; Royero, 1999: \#143; Akama, 2004: \#186), among examined species. The adipose fin is also 


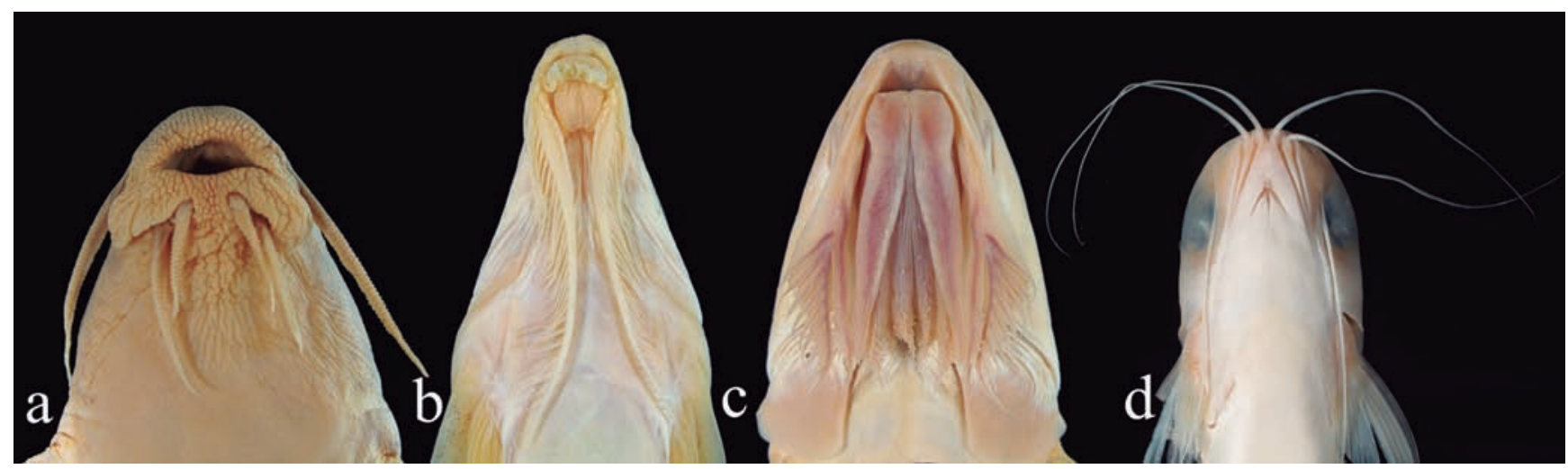

Fig. 6. Mouth, in ventral view, of (a) Rhinodoras dorbignyi, MCP 12419, $160.8 \mathrm{~mm}$ SL; (b) Tenellus trimaculatus, MZUSP 93421, 107.3 mm SL; (c) Leptodoras hasemani, MZUSP 37009, 133.7 mm SL; (d) Auchenipterus nuchalis, MZUSP 89728, 139.6 mm SL.

absent in the auchenipterid Gelanoglanis nanonocticolus, and some specimens of the doradids Physopyxis ananas and P. lyra (Eigenmann, 1925: 283; Sousa \& Rapp Daniel, 2005), taxa not included in the present analysis.

5. Shape of adipose fin (unordered): 0 - long and thick, with its base approximately as long as that of the anal fin; 1- short, thick and extended anteriorly as a low keel; 2- short, thin and teardrop-shaped (CI 0.25, RI 0.824).

In many species of catfishes the adipose fin is long and thick, with its base approximately as long as that of the anal fin (Figs. 3c, 4d), including those of the ariid Galeichthys (Marceniuk et al., 2012: \#212), Amphiliidae, Diplomystidae, Claroteidae, Erethistidae, Heptapteridae, Malapteruridae, Mochokidae, Pimelodidae, Pseudopimelodidae, and Sisoridae. However, the adipose fin is short, thick and extended anteriorly as a low keel in the doradids Centrochir, Centrodoras, Megalodoras, and Platydoras (Fig. 3b), a characteristic noticed by Eigenmann (1925: 283), and used in his identification key. The adipose fin is short, thin, and has the contour of a teardrop (Figs. 3a,d, 4a-c) in the ariid Genidens (Ariidae; Marceniuk et al., 2012: \#212), Auchenipteridae (except Epapterus, Trachelyichthys, Trachelyopterichthys, and Trachelyopterus), Ictaluridae (Lundberg, 1970: \#1), Pangasiidae, in doradids Acanthodoras, Agamyxis, Anduzedoras, Doras, Hassar, Hemidoras, Leptodoras, Nemadoras, Ossancora, Tenellus, and Trachydoras, and in the species of Astrodoradinae. All other species of the Doradidae have long and thick adipose fin. This character was coded as inapplicable for all examined taxa in which the adipose fin is absent (i.e., Aspredinidae, Nematogenyidae, Siluridae, and auchenipterids Epapterus, Trachelyichthys, Trachelyopterichthys, Trachelyopterus).

6. Gill-opening membranes (unordered): 0 - free from isthmus (and from each other); 1- united to isthmus at one single location; 2- united to isthmus across a large area; 3- united to each other (and free from isthmus) (CI 0.6, RI 0.818).

Members of several examined families of catfish have gill- opening membranes free from isthmus (and from each other), including the Amphiliidae, Claroteidae, Heptapteridae, Ictaluridae, Nematogenyidae, Pangasiidae, Pimelodidae, Pseudopimelodidae, and Siluridae. The examined species of the Diplomystidae, Erethistidae and Sisoridae have gillopening membranes united to the isthmus at a single location (Britto, 2002: \#299). The species of the Aspredinidae, Auchenipteridae, Doradidae, Malapteruridae, and Mochokidae (Vigliotta, 2008: \#92), on the other hand, have gill-opening membranes united to the isthmus across a large area (Fig. 6). The members of the Anchariidae and Ariidae have gill-opening membranes united to each other and free from the isthmus (Royero, 1999: \#114).

7. Distance between nares: 0- relatively large, distance greater than length of opening of anterior naris; 1- relatively small, distance approximately equal or smaller than length of opening of anterior naris (CI 0.333, RI 0.5).

Most examined species of catfish have the anterior and posterior nares distinctly apart, with distance between nares greater than length of opening of anterior naris (Fig. 5). However, the species of the Ariidae, Diplomystidae, Erethistidae, and Sisoridae, have the anterior and posterior nares close to each other, with distance approximately equal or smaller than length of opening of anterior naris (Mo, 1991; Britto, 2002: \#297; Marceniuk et al., 2012: \#221).

\section{Barbels.}

8. Oral hood: 0- absent; 1- present (CI 1.0, RI 1.0).

As previously discussed by several authors (Higuchi, 1992: \#A07, \#A08; Sabaj, 2002: \#8, \#9, \#10, \#11; Sabaj, 2005; Birindelli et al., 2008; Birindelli \& Sousa, 2010), the labial membrane in the doradids Anduzedoras and Leptodoras is expanded posteriorly and incorporates the bases of mental barbels forming the so-called oral hood (Fig. 6c; Sabaj, 2005: fig. 5). The oral hood is more developed in distal species of Leptodoras (Sabaj, 2005; Birindelli et al., 2008), but it is also present in Anduzedoras and basal most species of Leptodoras. In all other examined catfish, the aforementioned modification is absent. 
9. Dorsolateral membrane of maxillary barbel: 0- absent; 1present (CI and RI inapplicable).

A dorsolateral membrane (= dorsolabial membrane of Sabaj, 2005: fig. 1b) is present exclusively on the maxillary barbel of distal species of the doradid Leptodoras, including $L$. acipenserinus, L. cataniai, L. hasemani, L. juruensis, $L$. linnelli, L. myersi, L. nelsoni and L. rogersae (Sabaj, 2002: \#12; Sabaj, 2005).

10. Length of maxillary barbel: 0- maxillary barbel long, extending posteriorly beyond anterior margin of orbit; 1maxillary barbel short, not reaching the anterior margin of orbit (CI 1.0, RI 1.0).

The maxillary barbel is relatively long in most examined species of catfish, extending posteriorly beyond the anterior margin of orbit (Figs. 5, 7). However, the auchenipterids Ageneiosus and Tetranematichthys have the maxillary barbel extremely short, not reaching the anterior margin of orbit (Ferraris, 1988: \#J14; Royero, 1999: \#117; Akama, 2004: \#62).

11. Fimbriae on ventral face of maxillary barbel: 0 - absent; 1 present (CI 1.0, RI 1.0).

Most examined species of catfish have smooth maxillary barbel, without fimbriae (Figs. 6a, 7). However, the species of Anduzedoras, Doras, Hassar, Hemidoras, Leptodoras, Nemadoras, Ossancora, Tenellus, and Trachydoras have fimbriae on the ventral face of the maxillary barbel (Figs. 5, 6b,c; Higuchi, 1992: \#6). Synodontis clarias and S. annectes (Mochokidae) also have fimbriae on the maxillary barbel (Poll, 1971).

12. Fimbriae on dorsal face of maxillary barbel: 0 - absent; 1 present (CI 1.0, RI 1.0).

The doradids Ossancora asterophysa, O. eigenmanni, and $O$. fimbriata are the only examined species with fimbriae present on both ventral and dorsal surfaces of the maxillary barbel (Fig. 5a; Birindelli \& Sabaj Pérez, 2011).

13. Maxillary barbel movement: 0 - lateral; 1 - vertical (CI 1.0, RI 1.0).

The maxillary barbel moves laterally in most catfishes, whereas it moves vertically in the species of the Auchenipteridae (Fig. 7; Ferraris, 1988: \#J12; Akama, 2004:\#60).

14. Suborbital groove: 0- absent; 1- present (CI 1.0, RI 1.0).

The species of the Auchenipteridae have a suborbital groove in which the maxillary barbel fits when adpressed to body (Fig. 7; Ferraris, 1998: \#J16; Curran, 1989: \#2; Royero, 1999: \#116; Akama, 2004: \#61). That condition is absent in all other examined species (Fig. 5).

15. Transverse striae on barbels: 0 - absent; 1 - present (CI 1.0, RI 1.0).

All species of the doradid Rhinodoras have transverse striae on the maxillary and mental barbels (Fig. 6a). This condition is absent in all other examined species (Fig. 6b-d).

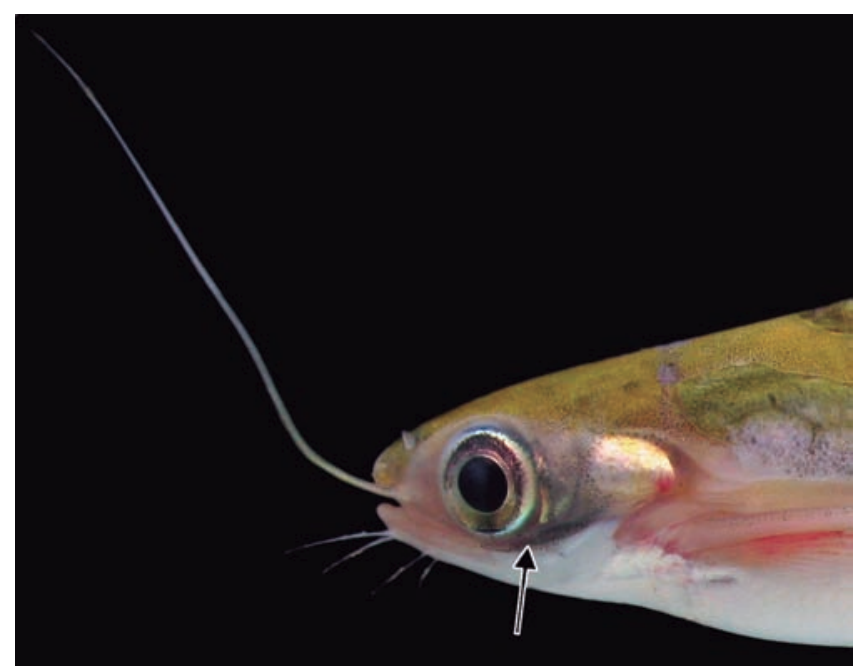

Fig. 7. Head, in lateral view, of Centromochlus heckelii, MZUSP 104793, 100 mm SL, photographed live; arrow indicates suborbital groove.

16. Number of mental barbels at each side of head (ordered): 0 - mental barbels absent; 1- one; 2- two (CI 0.333, RI 0.5).

Most catfishes have two mental barbels on each side of the head (Fig. 6). However, the Nematogenyidae, Pangasiidae, and auchenipterids Gelanoglanis and Tetranematichthys do not have the lateral mental barbel, whereas the Astroblepidae, Diplomystidae, Loricariidae, and auchenipterid Ageneiosus lack mental barbels entirely (Britski, 1972: 11; Arratia, 1987; Ferraris, 1988: \#J19, \#J22; Curran, 1989: \#23; Walsh, 1990: \#20, \#21; Royero, 1999: \#118; Akama, 2004: \#63; Marceniuk et al., 2012: \#225, \#226). In the Pangasiidae and auchenipterids Tetranematichthys and Ageneiosus the loss of mental barbels was interpreted as an adaptation to their pelagic habitat (Britski, 1972). The absence of mental barbels in the Diplomystidae is considered a primitive condition, and not a secondary loss as in the aforementioned taxa (Arratia, 1987).

17. Fimbriae on mental barbels: 0- absent; 1 - present (CI 0.25, RI 0.667).

In the doradids Ossancora (except $O$. punctata) and Hemidoras, the mental barbels have long, distinct fimbriae (Fig. 5a). The same condition is also present in the mochokids Mochokus, Mochokiella, Microsynodontis, and Synodontis (Vigliotta, 2008: \#88). In all other examined species, the mental barbels are either completely smooth or with delicate papillae (Figs. 5b,c). This character was coded as inapplicable for the Diplomystidae and auchenipterid Ageneiosus, which lack mental barbels.

18. Arrangement of fimbriae of mental barbels: 0 - one row; 1 two rows (CI 0.5, RI 0.5).

The doradids Ossancora fimbriata and Hemidoras, and mochokids Mochokus and Mochokiella have only one row of fimbriae on the mental barbels, whereas doradids Ossancora 
asterophysa and O. eigenmanni, and mochokids Microsynodontis and Synodontis (Vigliotta, 2008: \#89) have two rows. This character was coded as inapplicable in all examined taxa that either lack fimbriae on mental barbels or lack mental barbels entirely (i.e., all examined taxa except the species mentioned in this character discussion).

19. Length of mental barbels (one relative to the other): 0 lateral distinctly longer than medial; 1- lateral and medial approximately of the same length (CI 0.5, RI 0.969).

In most catfishes the lateral mental barbel is distinctly longer than the medial (Fig. 6a). However, in Anduzedoras, Doras, Hassar, Hemidoras, Leptodoras, Nemadoras, Ossancora, Tenellus, and Trachydoras (Higuchi, 1992: \#8), and in the auchenipterids Auchenipterus, Epapterus, and Pseudepapterus, the mental barbels are approximately the same length (Figs. 5, 6a,b). This character was coded as inapplicable for all species that lack at least one pair of mental barbel (i.e., Diplomystidae, Nematogenyidae, Pangasiidae, and auchenipterids Ageneiosus, Gelanoglanis, and Tetranematichthys).

20. Length of mental barbel (relative to body length): 0- short, not reaching the posterior tip of coracoid process; 1- long, surpassing the posterior tip of coracoid process (CI 0.2, RI 0.5).

The Ariidae, Pimelodidae and auchenipterids Auchenipterus, Entomocorus, Epapterus, Pseudauchenipterus, Pseudepapterus, and Trachelyopterus coriaceus have long mental barbels, surpassing the posterior tip of the coracoid process (Curran, 1989: \#6; Akama, 2004: \#64). All other examined species have mental barbels relatively short, not reaching the posterior tip of coracoid process (Fig. 6 ). This character was coded as inapplicable for the Diplomystidae and auchenipterid Ageneiosus, which lack mental barbels entirely.

21. Relative position of bases of mental barbels: 0- base of medial barbel anterior to that of lateral barbel; 1 - bases on medial and lateral barbels side by side (CI 0.5, RI 0.969).

In most catfishes, the insertion of the medial mental barbel is anterior to that of the lateral (Fig. 6). However, in the auchenipterids Auchenipterus, Epapterus, and Pseudepapterus, and doradids Anduzedoras, Doras, Hassar, Hemidoras, Leptodoras, Nemadoras, Ossancora, Tenellus, and Trachydoras, the mental barbels have their bases close to each other (side by side) and to the lower lip (Figs. 5; 6b-d; Ferraris, 1998: \#J18; Curran, 1989: \#13; Walsh, 1990: \#12; Ferraris \& Vari, 1999; Royero, 1999: \#119; Akama, 2004: \#65). This character was coded as inapplicable for all species that lack at least one pair of mental barbel (i.e., Diplomystidae, Nematogenyidae, Pangasiidae, and auchenipterids Ageneiosus, Gelanoglanis, and Tetranematichthys).

22. Nasal barbel associated with posterior naris: 0- absent; 1present (CI 0.25, RI 0.25).

Members of the Akysidae, Amblycipitidae, Bagridae,
Chacidae, Clariidae, Claroteidae, Cranoglanidae, Erethistidae, Ictaluridae, Pangasiidae, Plotosidae, Schilbeidae, and Sisoridae have a pair of nasal barbels, associated with the posterior nares (Britto, 2002: \#277). This condition is absent in all other examined species (Fig. 5).

\section{Skin and dermal structures.}

23. Unculiferous tubercles in males and females: 0 - absent or weakly developed; 1- well developed (CI 0.143, RI 0.7).

Tubercles with unculi are common in species of the Siluriformes (Roberts, 1982), although absent in some families, including the Diplomystidae (Arratia \& Huaquin, 1995). Among examined species, well-developed unculiferous tubercles are present in male and females of the Amphiliidae, Aspredinidae, Erethistidae, Sisoridae, pseudopimelodids Cephalosilurus fowleri and Lophiosilurus alexandri, mochokid Chiloglanis, and doradids Centrodoras, Leptodoras juruensis, L. myersi, Lithodoras, Megalodoras, Orinocodoras, Oxydoras, Pterodoras, Rhinodoras, and Rhynchodoras (Fig. 8; Wiley \& Collette, 1970; Collette, 1977; Roberts, 1982; Arratia \& Huaquin, 1995; de Pinna, 1996; Sabaj, 2005; Sousa, 2010: \#101). Unculiferous tubercles are weakly developed (or completely absent) in male and females of Auchenipteridae, Ariidae, Claroteidae, Diplomystidae, Heptapteridae, Ictaluridae, Malapteruridae, Nematogenyidae, Pangasiidae, Pimelodidae, Siluridae, Mochokidae (except

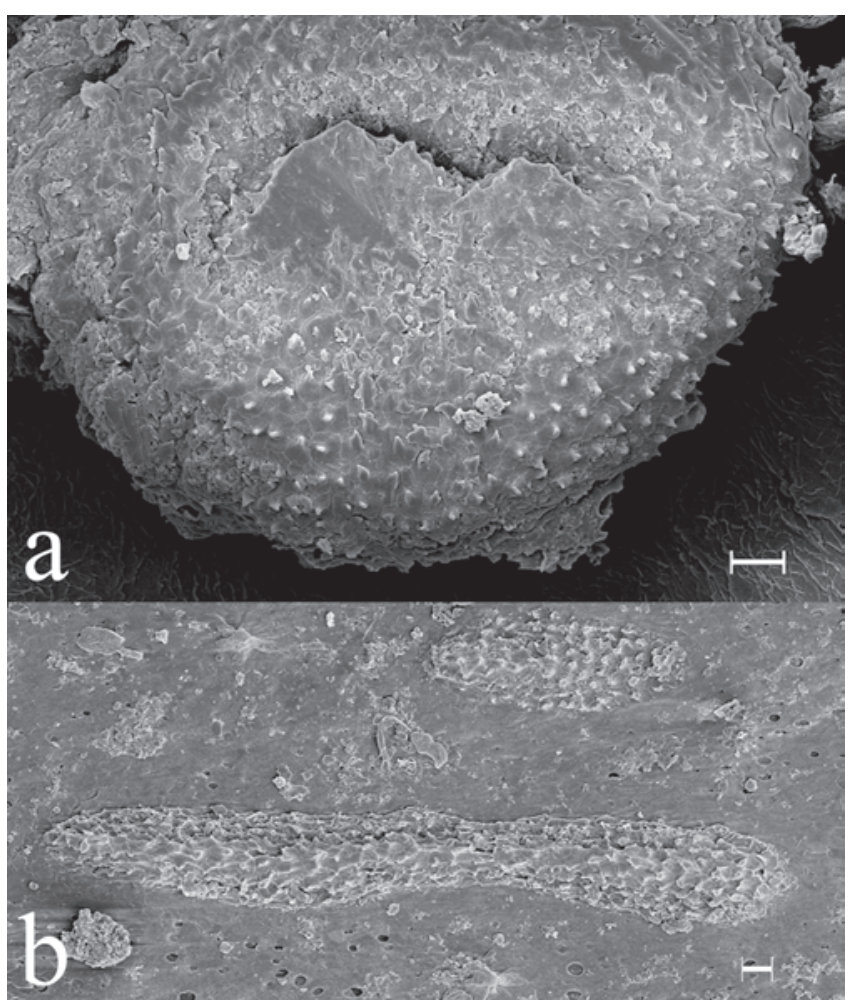

Fig. 8. SEM images of the unculiferous tubercles in (a) Rhinodoras dorbignyi, MZUSP 62688, $102 \mathrm{~mm} \mathrm{SL}$; and (b) Leptodoras myersi, MZUSP 56676, 118 mm SL. Scale bars equal 20 ìm. 
Chiloglanis), and Doradidae (except taxa mentioned above). Unculiferous tubercles are present and well developed in mature males of some species of the Auchenipteridae, these are, however, nuptial and treated in distinct characters.

24. Nature of unculiferous tubercles: 0- tubercles independent, not forming plates; 1 - tubercles forming plates (CI 1.0, RI 1.0).

The species of the Akysidae, Erethistidae, and Sisoridae have well-developed unculiferous tubercles forming conspicuous plates (Roberts, 1982). This character was coded as inapplicable for all examined species without welldeveloped unculiferous tubercles (i.e., Auchenipteridae, Ariidae, Claroteidae, Diplomystidae, Heptapteridae, Ictaluridae, Malapteruridae, Nematogenyidae, Pangasiidae, Pimelodidae, Siluridae, Mochokidae, except Chiloglanis, and Doradidae, except mentioned in previous character).

25. Breeding tubercles on maxillary barbel: 0- absent; 1present (CI 0.5, RI 0.75).

Some species of the Auchenipteridae have well-developed unculiferous tubercles as a sexually dimorphic feature, and in that case, these might be correctly called breeding tubercles. Mature males of the auchenipterids Auchenipterus, Entomocorus, Pseudepapterus, Epapterus, and Tetranematichthys have well-developed tubercles on the maxillary barbel (Ferraris \& Vari, 1999; Akama, 2004: \#177). This character was coded as missing data for the auchenipterids Pseudotatia and Spinipterus.

26. Breeding tubercles on dorsal surface of head: 0 - absent; 1- present (CI 1.0, RI 1.0).

Mature males of the auchenipterids Auchenipterus, Entomocorus, Epapterus, and Pseudepapterus have welldeveloped tubercles on the dorsal surface of head. These tubercles are cone-shaped and large in Entomocorus, dotlike in Auchenipterus, anastomosed in Pseudepapterus and dash- or dot-like in Epapterus (Akama, 2004: \#178). This character was coded as missing data for the auchenipterids Pseudotatia and Spinipterus.

27. Breeding tubercles on dorsal-fin spine, pectoral-fin spine, pelvic fin, abdomen and isthmus: 0- absent; 1 - present (CI and RI inapplicable).

Mature males of the auchenipterid Entomocorus have welldeveloped tubercles on the dorsal-fin spine (Akama, 2004: \#176), pectoral-fin spine, pelvic fin, abdomen (Akama, 2004: \#179) and isthmus (Akama, 2004: \#180; see also Akama \& Ferraris, 2004). No other examined species have such characteristics. This character was coded as missing data for the auchenipterids Pseudotatia and Spinipterus.

28. Breeding tubercles on tip of anteriormost anal-fin rays: 0absent; 1- present (CI 1.0, RI 1.0).

Mature males of the auchenipterids Auchenipterus, Epapterus, and Pseudepapterus have well-developed tubercles on the tip of anteriormost anal-fin rays (Akama, 2004: \#182). All other examined taxa lack this feature. This character was coded as missing data for the auchenipterids Pseudotatia and Spinipterus.

29. Papilla-like tubercles on tympanic area: 0- absent; 1present (CI and RI inapplicable).

Species of the auchenipterid Pseudauchenipterus have well-developed papilla-like tubercles on the tympanic area (Akama, 1999; Royero, 1999: \#148; Akama, 2004: \#183). This feature is absent in all other examined species.

30. Glandular tissue on axilla: 0- absent; 1 - present (CI 0.25, RI 0.864).

Glandular tissue and associated numerous pores on the axilla area, immediately ventral to the anteriormost portion of the posterior cleithral process (Fig. 9), were described for the doradid Rhynchodoras (Birindelli et al., 2007), Doras (Sabaj Pérez \& Birindelli, 2008: fig. 2), and are also present in Trachydoras, Nemadoras, Tenellus, Hassar, Anduzedoras, and the most basal species of Leptodoras (L. marki, L. oyakawai, L. praelongus, L. copei, L. hasemani; Sabaj, 2002: \#30; Sabaj, 2005). As the single pore present in most catfishes, the glandular tissue and associated pores in the aforementioned taxa produce mucous (Burgess, 1989: 201).

31. Glandular tissue on surface of abdomen: 0- absent; 1present (CI 1.0, RI 1.0).

As described by Sabaj Pérez \& Birindelli (2008), the species of the doradid Doras have glandular tissue and associated numerous pores on the abdomen, which may be restricted to the anal opening as in $D$. carinatus, $D$. micropoeus and $D$. higuchii (Fig. 10a), or widespread on the abdomen as in $D$. phlyzakion and D. zuanoni (Figs. 10b,c). Like the axillary pores beneath the posterior cleithral process, the abmonimal grandular tissue produces mucuos. All other examined species lack this characteristic.

32. Dermal scutes between dorsal and adipose fins, and between anal opening and anal fin, in specimens of more than

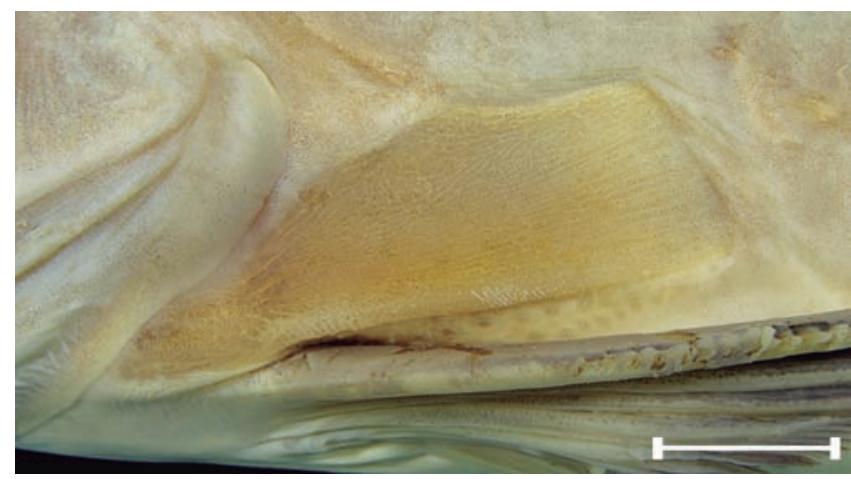

Fig. 9. Posterior cleithral process in Doras micropoeus, ANSP 177880, 274 mm SL, photo by Mark Sabaj Pérez. Scale bar equals $10 \mathrm{~mm}$. 


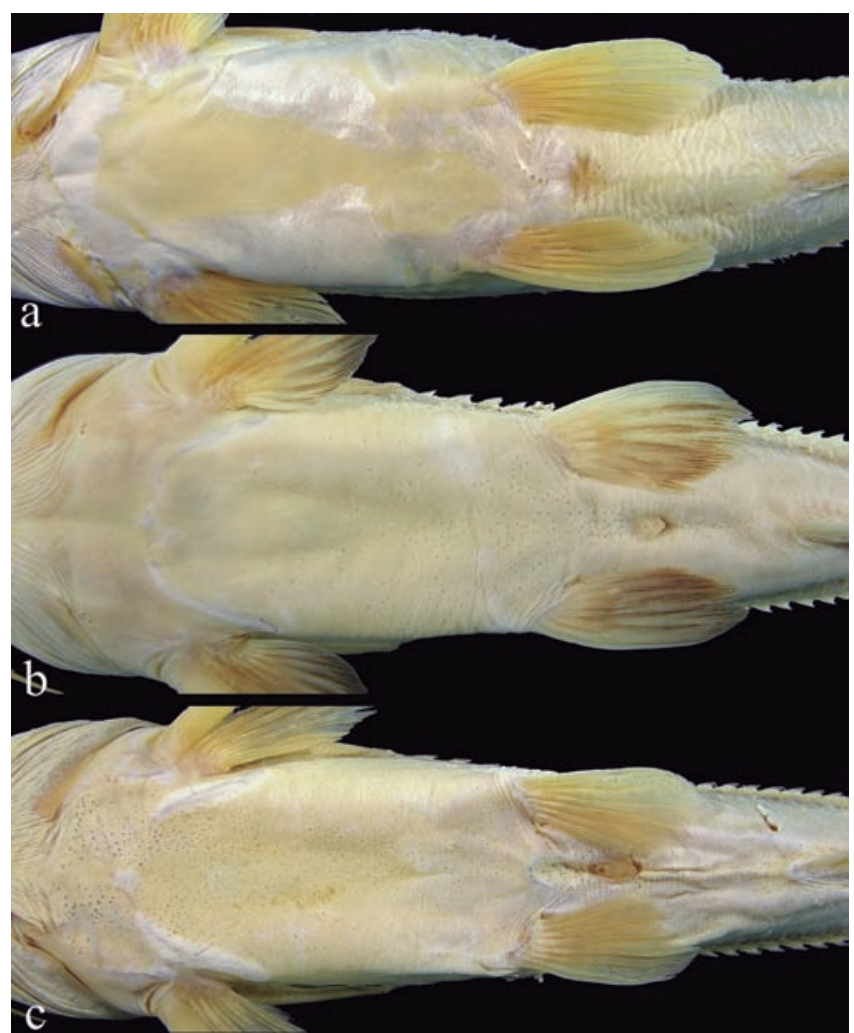

Fig. 10. Ventral body in (a) Doras higuchii, INPA 45052, 153 mm SL; (b) Doras zuanoni, INPA 5244, 124 mm SL; and (c) Doras phlyzakion, ANSP 181055, 169 mm SL, photos by Mark Sabaj Pérez.
50 mm SL: 0- absent; 1-present (CI 0.5, RI 0.0).

Dermal scutes between the dorsal and adipose fins, and between the anal opening and anal fin are only present in the doradids Hemidoras morrisi and $H$. stenopeltis. The doradid genus Hemidoras was erected by Eigenmann (1925) to comprise these two species on the basis of the presence of dermal scutes between the dorsal and adipose fins, and also between the anal opening and anal fin (Eigenmann, 1925: 346; Higuchi, 1992: \#A85). A somewhat similar condition is present in Lithodoras dorsalis. The latter, however, has dermal scutes with irregular margins completely covering the ventral, lateral and dorsal surfaces of body in specimens larger than 150 mm SL (Eigenmann, 1925: 318; Higuchi, 1992: \#A84). Since the condition in Lithodoras is distinct from that observed in Hemidoras morrisi and H. stenopeltis, the former was coded as having state 0 for this character.

\section{Gas bladder morphology}

33. Size of gas bladder: 0- large, occupying at least half of retroperitoneal cavity; 1 - small, occupying less than half of retroperitoneal cavity (CI 0.333, RI 0.5).

The gas bladder occupies most of the retroperitoneal cavity in most catfishes. However, it is reduced in size, occupying less than half of the retroperitoneal cavity in the doradids Rhynchodoras (Birindelli et al., 2007), Leptodoras (except L. oyakawai and L. marki) (Figs. 11d-f; Sabaj, 2005; Birindelli et al., 2008; Birindelli \& Sousa, 2010; Birindelli et al., 2009: fig. 18), and in the auchenipterid Ageneiosus (except $A$. atronasus, A. brevis, A. pardalis, and A. piperatus) (Figs. 11a-c; Bridge \& Haddon, 1892: 156; Chardon, 1968; Britski,

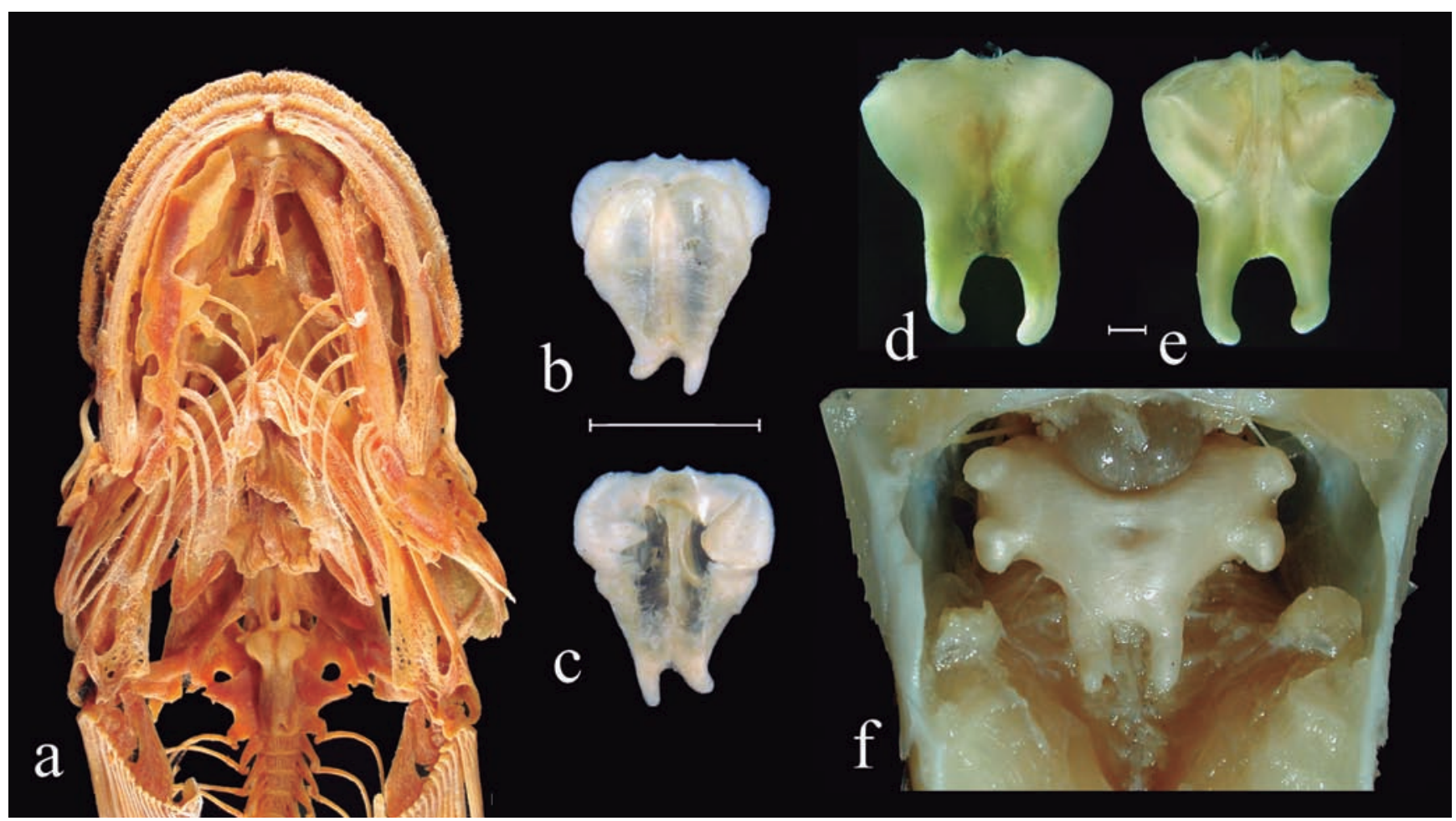

Fig. 11. Anterior portion of head and body in (a) Ageneiosus inermis, MZUSP 91661, $320 \mathrm{~mm}$ SL. Gas bladder in ventral (b,d) and dorsal (c,e) of (b,c) Ageneiosus inermis, MZUSP 9384, 77 mm SL; (d,e) Rhynchodoras woodsi, ANSP 181042, 72.5 mm SL. Ventral view of body cavity of (f) Leptodoras cataniai, INHS 39814, 111.1 mm SL. Scale bars equal 5 mm. Photos (d,e,f) by Mark Sabaj Pérez. 
1972: 23; Ferraris, 1988: \#V9; Walsh, 1990: \#24; Royero, 1999: \#147; Akama, 2004: \#74; Birindelli et al., 2012). Only a few other catfishes have a somewhat similar condition, including the bagrid Rheoglanis dendrophorus (see Chardon, 1968: fig. 35), and the pimelodids Callophysus, Luciopimelodus, Aguarunichthys, and Pinirampus (Chardon, 1968; Stewart, 1986). This character was coded as missing data for the auchenipterids Pseudotatia and Spinipterus.

34. Gas-bladder wall: 0- not ossified; 1- ossified (CI and RI inapplicable).

Among examined taxa, the gas bladder is reduced and its tunica externa ossified only in the auchenipterids Ageneiosus inermis, A. marmoratus, A. polystictus, A. vittatus, and some specimens of A. ucayalensis (Figs. 11a-c; Walsh, 1990; Birindelli et al., 2012). A similar condition is present in Hypophthalmus (Chardon, 1968). This character was coded as missing data for the auchenipterids Pseudotatia and Spinipterus.

35. Terminal diverticula of gas bladder: 0 - absent; 1 - present (CI 0.143, RI 0.6).

The posterior chambers of the gas bladder are expanded posteriorly as terminal diverticula in the doradids Acanthodoras, Agamyxis, Astrodoras, Doras zuanoni, Hemidoras, Ossancora punctata, Trachydoras, and auchenipterids Centromochlus heckelii, Trachelyopterus ceratophysus, T. fisheri, T. galeatus, T. peloichthys, T. porosus, T. teaguei, T. striatulus and Trachycorystes trachycorystes (Fig. 12; Akama, 2004: \#71; Birindelli et al., 2009; Sousa, 2010: \#91; Birindelli et al., 2012). This character was coded as missing data for the auchenipterids Pseudotatia and Spinipterus.

36. Tips of terminal diverticula of gas bladder: 0- medially united; 1 - distally divergent (CI 0.5, RI 0.8).

The terminal diverticula of the gas bladder are medially united in the doradids Acanthodoras, Agamyxis, Astrodoras, Hemidoras, and auchenipterids Centromochlus heckelii, Trachycorystes trachycorystes and some specimens of Trachelyopterus galeatus (Fig. 12b). The terminal diverticula diverge distally in the doradids Doras zuanoni, Ossancora punctata, and Trachydoras (Fig. 12a; Birindelli et al., 2009; Sousa, 2010: \#93; Birindelli et al., 2012), and auchenipterids
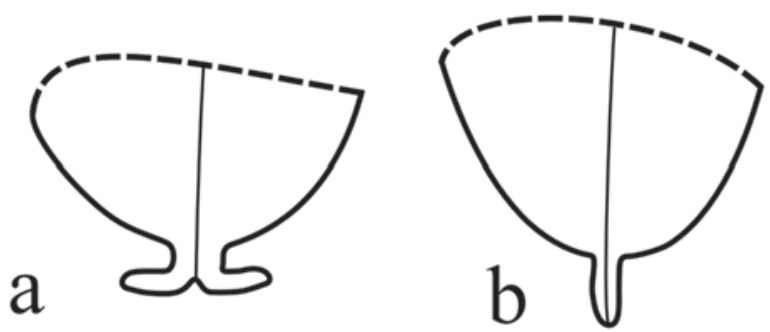

Fig. 12. Schematic drawing of the posterior portion of the gas bladder showing (a) terminal diverticula distally divergent, and (b) terminal diverticula medially united. Modified from Birindelli et al. (2009: fig. 2).
Trachelyopterus ceratophysus, T. fisheri, T. peloichthys, $T$. porosus, T. striatulus, T. teaguei and some specimens of $T$. galeatus (Akama, 2004: \#71; Birindelli et al., 2012). This character was coded as inapplicable for all taxa without terminal diverticula on the gas bladder (i.e., all examined taxa except those mentioned in the previous character); as polymorphic for Trachelyopterus galeatus; and as missing data for Pseudotatia and Spinipterus.

37. Secondary chamber of gas bladder: 0- absent; 1 - present (CI 0.083, RI 0.421).

The secondary chamber of the gas bladder, as defined by Birindelli et al. (2009), is formed by enlargement of the terminal diverticulum(a), which become(s) distinct from the main bladder by a basal constriction. The secondary chamber is present in the doradids Centrodoras, Doraops, Doras carinatus, $D$. micropoeus, D. higuchii, Lithodoras, Megalodoras, Orinocodoras, Oxydoras, Platydoras (except Platydoras sp.), Pterodoras rivasi, Rhinodoras thomersoni, $R$. dorbignyi and Scorpiodoras, and auchenipterids Auchenipterichthys, and Tetranematichthys (Fig. 13; Britski, 1972: 33; Higuchi, 1992: \#114; Akama 2004: \#72; Sousa, 2010: \#94; Birindelli et al., 2012). The same condition is also present in members of the Malapteruridae (Bridge \& Haddon, 1892: fig. 71), Pangasiidae (Bridge \& Haddon, 1892: fig. 93), and in some species of the Ictaluridae (Lundberg, 1970: \#91) and Pimelodidae (Lundberg \& Akama, 2005). This character was coded as missing data for the auchenipterids Pseudotatia and Spinipterus.

38. Nature of the secondary chamber of gas bladder: 0 - formed by both posterior chambers, thus with an inner septum; 1formed by a single posterior chamber, thus without an inner septum (CI 0.5, RI 0.75).

The secondary chamber of the gas bladder is formed from both posterior chambers, and thus has an medial septum in the Malapteruridae, Pangasiidae, doradids Centrodoras, Doraops, Megalodoras, Lithodoras, Orinocodoras, Pterodoras rivasi, Rhinodoras thomersoni, R. dorbignyi, and Scorpiodoras, and auchenipterids Auchenipterichthys and Tetranematichthys (Fig. 13b; Britski, 1972: 33; Higuchi, 1992:
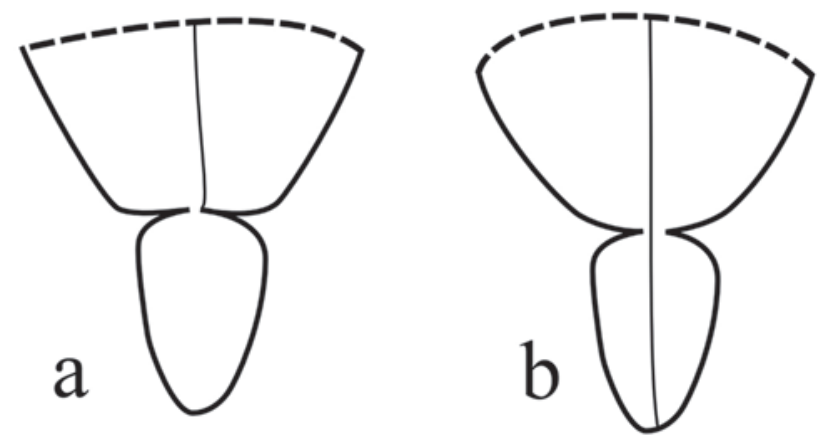

Fig. 13. Schematic drawing of the posterior portion of the gas bladder showing (a) secondary chamber formed by both posterior chambers, and (b) secondary chamber formed by a single posterior chamber. Modified from Birindelli et al. (2009: fig. 2). 
\#114; Akama 2004: \#72; Sousa, 2010: \#95; Birindelli et al., 2012). The secondary chamber is formed by a single posterior chamber, thus without internal septum (Fig. 13a), in the doradids Doras carinatus, D. higuchii, and D. micropoeus, Oxydoras and Platydoras (except Platydoras sp. which lacks secondary chamber). This character was coded as inapplicable for all taxa that lack the secondary bladder (i.e, all examined taxa, except those mentioned in the previous character); and as missing data for Pseudotatia and Spinipterus.

39. Subterminal diverticula of gas bladder (unordered): 0absent; 1- digitiform; 2- horn-like; 3- extremely well developed and branched (CI 0.375, RI 0.375).

The doradids Agamyxis and Doras phlyzakion, and auchenipterids Tocantinsia and Trachycorystes have a pair of digitiform subterminal diverticula (Fig. 14a-d; Birindelli et al., 2009; Sabaj Pérez \& Birindelli, 2008; Birindelli et al., 2012). The Doradids Leptodoras (except L. marki and L. oyakawai) and Rhynchodoras woodsi, and auchenipterid Ageneiosus (except A. pardalis and A. ucayalensis) have a pair of hornlike subterminal diverticula (Fig. 11; Walsh, 1990; Sabaj, 2002: \#5; Akama, 2004: \#71; Birindelli et al., 2007; Birindelli et al., 2009; Birindelli et al., 2012). The doradid Pterodoras granulosus has a pair of extremely well developed and branched subterminal diverticula (Fig. 14e; Birindelli et al., 2009; Sousa, 2010: \#97). All other examined species have a gas bladder without subterminal diverticula. This character was coded as missing data for the auchenipterids Pseudotatia and Spinipterus.

40. Inner trabeculae of gas bladder: 0 - absent; 1 - present (CI 0.167-0.2, RI 0.667-0.733).

Inner trabeculae are present in the gas bladder of most medium to large sized species of Doradidae, including Doraops, Lithodoras, Megalodoras, Pterodoras, Orinocodoras, Oxydoras, and Rhinodoras (Fig. 15a; Sousa, 2010: \#100). The same condition is also present in the Ariidae (Bridge \& Haddon, 1892: fig. 44; Marceniuk \& Birindelli, 2010), Bagridae (Bridge \& Haddon, 1892: fig. 18), Heptapteridae (Chardon, 1968: fig. 57), and Pimelodidae (Bridge \& Haddon,
1892: fig. 34). All other examined taxa have a gas bladder without inner trabeculae. This character was coded as missing data for auchenipterids Pseudotatia and Spinipterus.

41. Lateral diverticula on gas bladder (ordered): 0- absent; 1 present only on the main bladder; 2- present on the main bladder and on the secondary chamber of the bladder (CI 0.25, RI 0.867).

All examined species of the Doradinae, except Doras carinatus, D. higuchii, D. micropoeus, D. phlyzakion, Leptodoras oyakawai, Ossancora punctata, Rhinodoras thomersoni, and Rhynchodoras have lateral diverticula on the main bladder (Fig. 15; Higuchi, 1992: \#113, \#115; Sabaj, 2002: \#4; Sousa, 2010: \#98, \#99). The only other examined taxon with lateral diverticula on the main bladder is the auchenipterid Asterophysus batrachus (Britski, 1972; Akama, 2004; Birindelli et al., 2012). Lateral diverticula are present on both the main bladder and on the secondary chamber of the gas bladder in Centrodoras, Doraops, Lithodoras, Megalodoras, and Pterodoras (Fig. 15a). This character was coded as missing data for the auchenipterids Pseudotatia and Spinipterus.

42. Diverticula on ventral wall of gas bladder: 0- absent; 1present (CI 0.5, RI 0.667).

The gas bladder in the auchenipterid Asterophysus and doradid Nemadoras is almost completely surrounded by diverticula, which are also distributed on its ventral wall (Fig. 16; Birindelli et al., 2009; Birindelli et al., 2012). All other examined species have a gas bladder with the ventral wall lacking diverticula. This character was coded as missing data for auchenipterids Pseudotatia and Spinipterus.

\section{Reproductive system.}

43. Mode of reproduction: 0- without insemination; 1 - by insemination (CI 1.0, RI 1,0).

The Auchenipteridae is unique among catfishes in having reproduction by insemination. This characteristic was recorded for several species of auchenipterids based on observations of reproduction in captivity (Burgess \& Azuma,

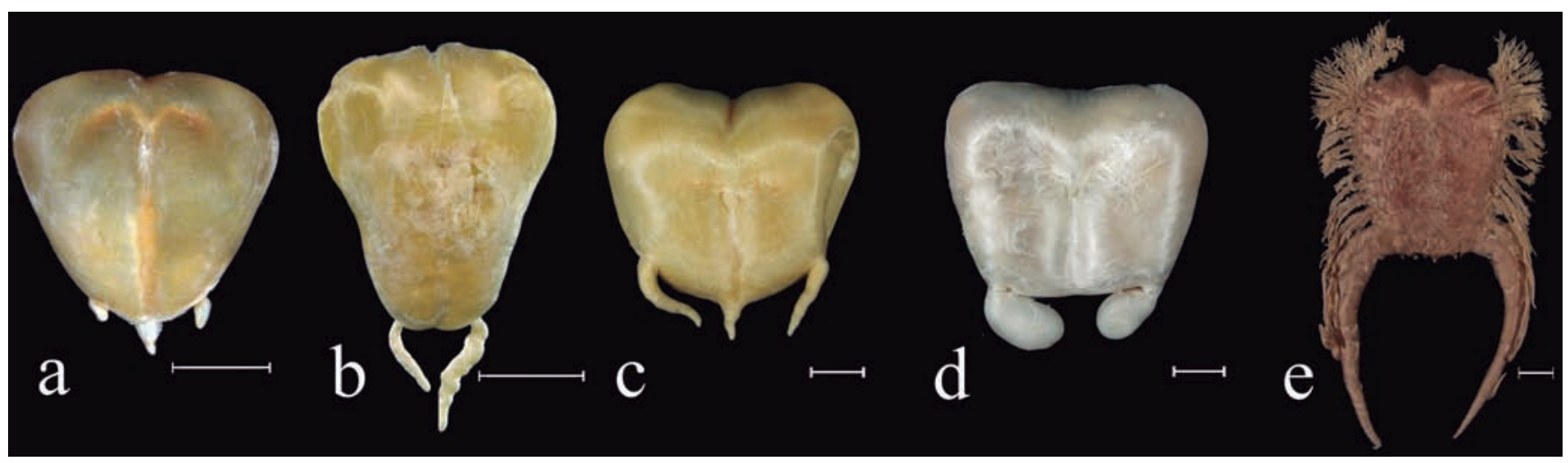

Fig. 14. Gas bladders in ventral view of (a) Agamyxis pectinifrons, MZUSP 27806, 83.3 mm SL; (b) Doras higuchii, ANSP 181057, 160 mm SL; (c) Trachycorystes trachycorystes, MZUSP 99308, 180 mm SL; (d) Tocantinsia piresi, MZUSP 98301 , 264 mm SL; and (e) Pterodoras granulosus, MZUSP 91441, 202.0 mm SL. Scale bars equal 10 mm. Photo (b) by Mark Sabaj Pérez. 

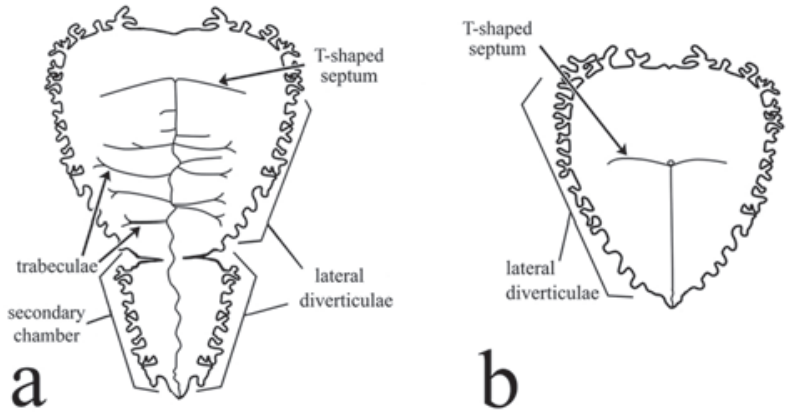

Fig. 15. Schematic drawing of gas bladders in ventral view, showing T-shaped septum, lateral diverticula, trabeculae (a), and secondary chamber (a). Modified from Birindelli et al. (2009: fig. 2).

1982; Franke, 1990), on studies of sperm morphology (Ihering, 1937; Burns et al., 2002; Parreira et al., 2009), morphology of the male reproductive tract (Mazzoldi et al., 2007; Meisner et al., 2009), and the presence of spermatozoa in the ovarian lumen found in some species (Parreira et al., 2009). Furthermore, reproduction by insemination is herein inferred to be present in all species of Auchenipteridae due to the fact that they all have the anal fin modified in mature males for insemination.

44. Posterior testicular lobes (unordered): 0 - similar to anterior ones (unmodified); 1- modified into hypertrophied storage bags; 2- rudimentary or absent (CI 0.4, RI 0.769).

Most catfishes have the posterior testicular lobes similar to the anterior ones (Figs. 17a-c; Ihering, 1937; Britski, 1972; Loir, 1989; Royero, 1999: \#120; Akama, 2004:\#142). However, some auchenipterids, including Auchenipterichthys, Glanidium, Liosomadoras, Pseudauchenipterus, Pseudepapterus, Tetranematichthys, Tocantinsia, Trachelyichthys, Trachelyopterichthys, Trachelyopterus, and Trachycorystes, have the posterior testicular lobes modified into storage bags (Figs. 17d; Akama, 2004: \#142; Mazzoldi et al., 2007; Meisner et al., 2009). The auchenipterids Ageneiosus and Auchenipterus lack the posterior testicular lobes (Fig. 17e). This character was coded as missing data for the auchenipterids Entomocorus, Epapterus, Gelanoglanis, Pseudotatia, and Spinipterus.

45. Main testicular duct: 0- tubular (unmodified); 1- modified into a swollen storage tube (CI 0.5, RI 0.5).

The main testicular duct of most catfishes is tubular. However, the auchenipterids Asterophysus, Centromochlus, and Tatia have the main testicular duct modified into a swollen storage tube (Akama, 2004: \#149). This character was coded as missing data for the auchenipterids Entomocorus, Epapterus, Gelanoglanis, Pseudotatia, and Spinipterus.

46. Position of urogenital opening in males (ordered): 0 - near anus; 1- at base of first anal-fin ray; 2- at the tip of anterior anal-fin rays (CI 1.0, RI 1.0).

Most catfishes have the urogenital opening near the anus. However, the species of Auchenipterinae possesses a long and thick urogenital tube whose opening is located at the tip of the anterior anal-fin rays (Figs. 18b-f; Ihering, 1937; Britski, 1972; Ferraris, 1988: \#A3, \#A4; Royero, 1999: \#122; Akama, 2004: \#142). The urogenital opening of species of the Centromochlinae, on the other hand, is located in the region immediately anterior to the base of the first anal-fin ray (Fig. 18a; Soares Porto, 1998; Reis \& Borges, 2006). In the auchenipterid Entomocorus the urogenital opening in mature males is located in a small tube that runs parallel to the anterior anal-fin rays to half of their length, in a condition similar to maturing males of the auchenipterids Asterophysus (Fig. 18c), Liosomadoras and Spinipterus (Akama \& Ferraris, 2011).

47. Urogenital opening in mature males: 0 - rounded; 1 - in the shape of a slit (CI 1.0, RI 1.0).

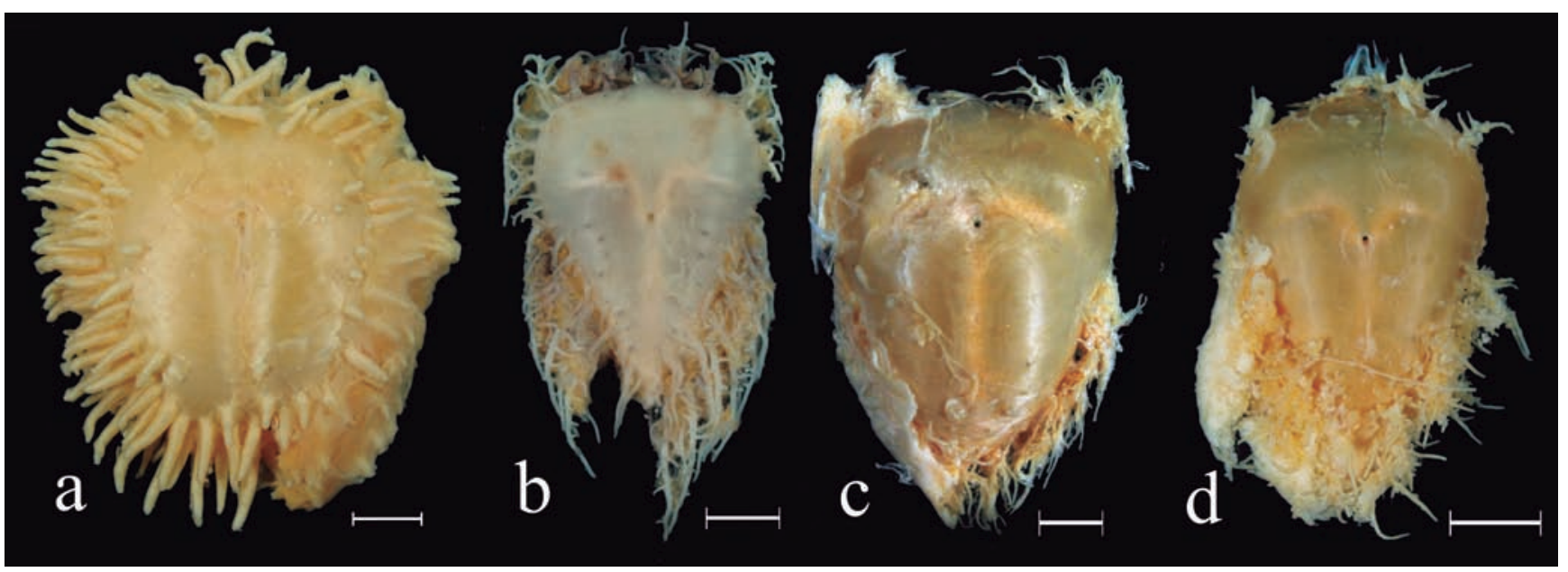

Fig. 16. Gas bladder in ventral view of (a) Asterophysus batrachus, MZUSP 12420, 129.7 mm SL; (b) Nemadoras hemipeltis, MZUSP 56688, 81.8 mm SL; (c) Nemadoras humeralis, MZUSP 56014, 103.8 mm SL; (d) Nemadoras elongatus, MZUSP 56013, $99.2 \mathrm{~mm}$ SL. Scale bars equal $5 \mathrm{~mm}$. 


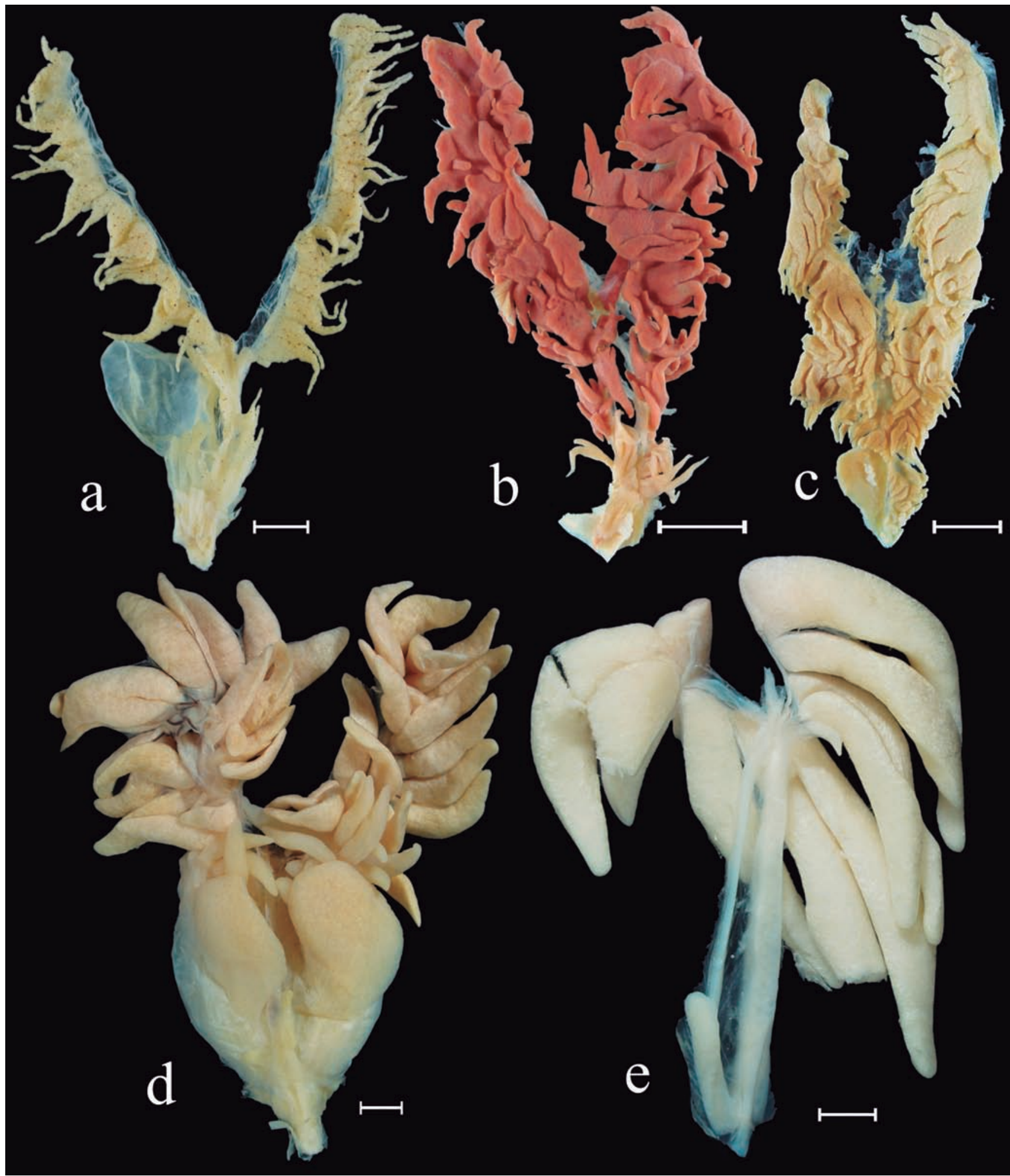

Fig. 17. Testes in ventral view of (a) Wertheimeria maculata, MZUSP 93658, $173 \mathrm{~mm}$ SL; (b) Acanthodoras cataphractus, MZUSP 6831, 116 mm SL; (c) Hemidoras morei, MZUSP 31104, 166 mm SL; (d) Trachelyopterus galeatus, MZUSP 90742, 154 mm SL; (e) Ageneiosus ucayalensis, MZUSP 98333, 165 mm SL. Scale bars equal 5 mm. 
The urogenital opening is rounded in mature males of most catfishes. However, it is shaped in the form of a slit in mature males of the auchenipterids Auchenipterus, Epapterus, and Pseudepapterus (Akama, 2004: \#149). This character was coded as missing data for the auchenipterids Pseudotatia and Spinipterus.

48. Distal vesicle on anterior anal-fin rays of mature males: 0absent; 1- present (CI and RI inapplicable).

Mature males of the auchenipterid Pseudauchenipterus have a vesicle on the distal portion of the anterior anal-fin rays (Fig. 18d; Akama, 2004: \#149). This feature is not present in any other examined species. This character was coded as missing data for the auchenipterids Pseudotatia and Spinipterus.
49. Gap between modified anterior and remaining anal-fin rays of mature males: 0- absent; 1- present (CI and RI inapplicable).

Among examined species, only mature males of the auchenipterid Epapterus have a gap between the modified anterior anal-fin rays and the remaining ones (Fig. 18b). This character was coded as missing data for the auchenipterids Pseudotatia and Spinipterus.

50. Urogenital opening in females: 0 - narrow, 1- wide (modified for insemination) (CI 0.5, RI 0.941).

The urogenital opening is narrow in females of most catfishes (Fig. 19a-c). However, females of all auchenipterids, except Centromochlus, Gelanoglanis, and Tatia, have a wide urogenital opening, enlarged for insemination (Figs. 19d-f; Royero, 1999: \#124; Akama, 2004: \#144). This character was

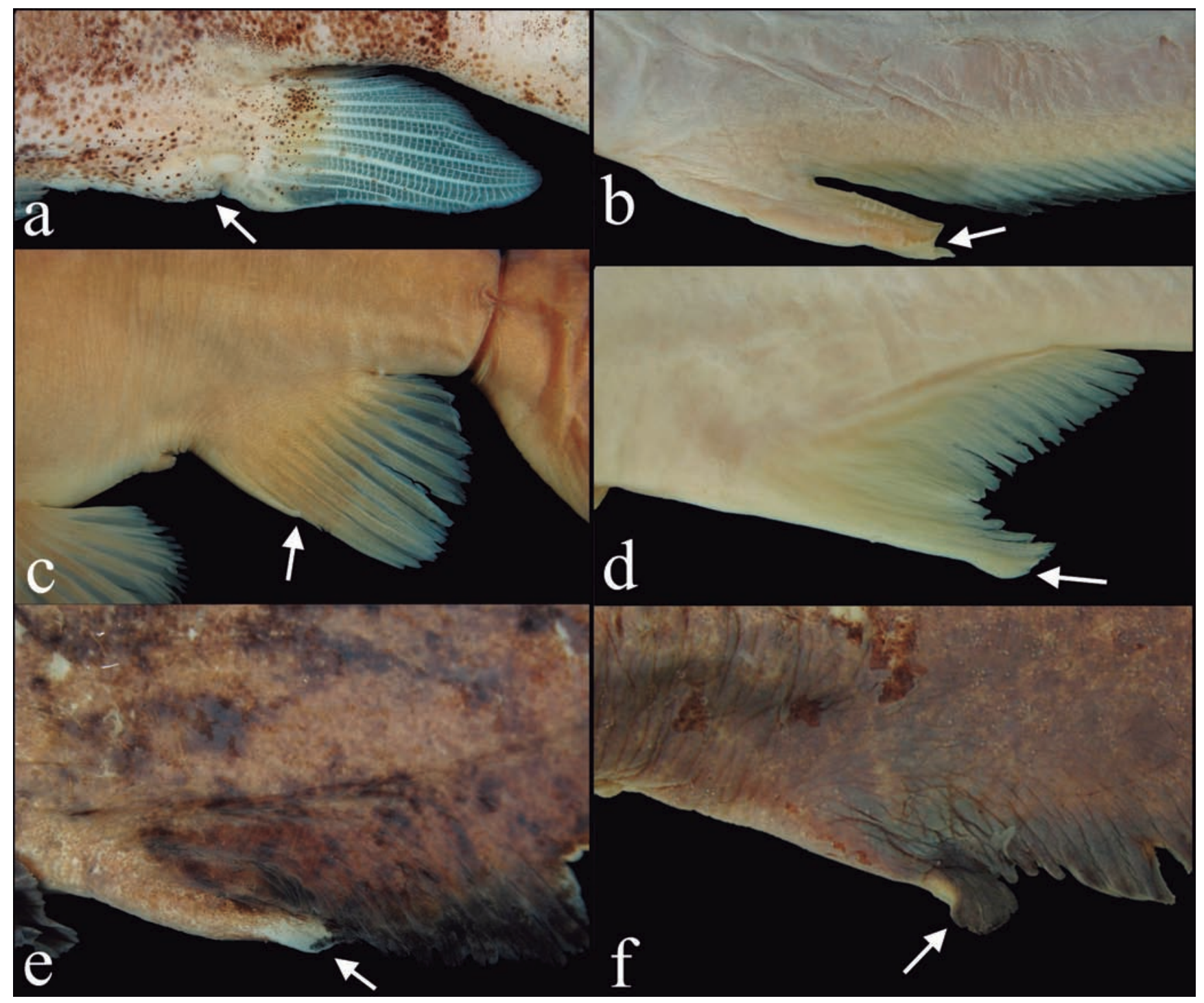

Fig. 18. Anal fin in lateral view of mature (a-b,d-f) or maturing (c) males of (a) Glanidium melanopterum, MZUSP 64256, 105 mm SL; (b) Epapterus dispilurus, MZUSP 26183, 107 mm SL; (c) Asterophysus batrachus, MZUSP 12420, 129.7 mm SL; (d) Pseudauchenipterus jequitinhonhae, MZUSP 51734, 100.9 mm SL; (e) Trachelyopterus galeatus, MZUSP 79345, 106.3 mm SL; (f) Trachelyopterus sp., MZUSP 79345, 106.3 mm SL. Arrows indicate urogenital opening. 
coded as missing data for the auchenipterids Pseudotatia and Spinipterus.

\section{Neurocranium.}

51. Origin of adductor mandibulae muscle: 0- on medial cephalic crest (parietal-supraoccipital); 1- on border of neurocranium (sphenotic, pterotic) (CI 0.333, RI 0.333).

In members of the Diplomystidae, Cetopsidae, Ictaluridae, Malapteruridae, and Nematogenyidae, the adductor mandibulae muscle has its origin on the medial cephalic crest (parietal-supraoccipital), and covers the lateral bones of the neurocranium (sphenotic and pterotic; Fig. 20; Alexander, 1965; Lundberg, 1970; de Pinna et al., 2007). However, in all other catfishes examined, the adductor mandibulae originates on the lateral border of the cranium (sphenotic and pterotic), leaving the dorsalmost bones exposed, especially the parietalsupraoccipital and frontals (Figs. 21-31).

52. Shape of mesethmoid (unordered): 0 - in shape of an " $X$ "; 1- wide, in shape of a square; 2 - in shape of an arrow, medially dilated (CI 0.25, RI 0.895).

In most catfishes, the mesethmoid is in the shape of an

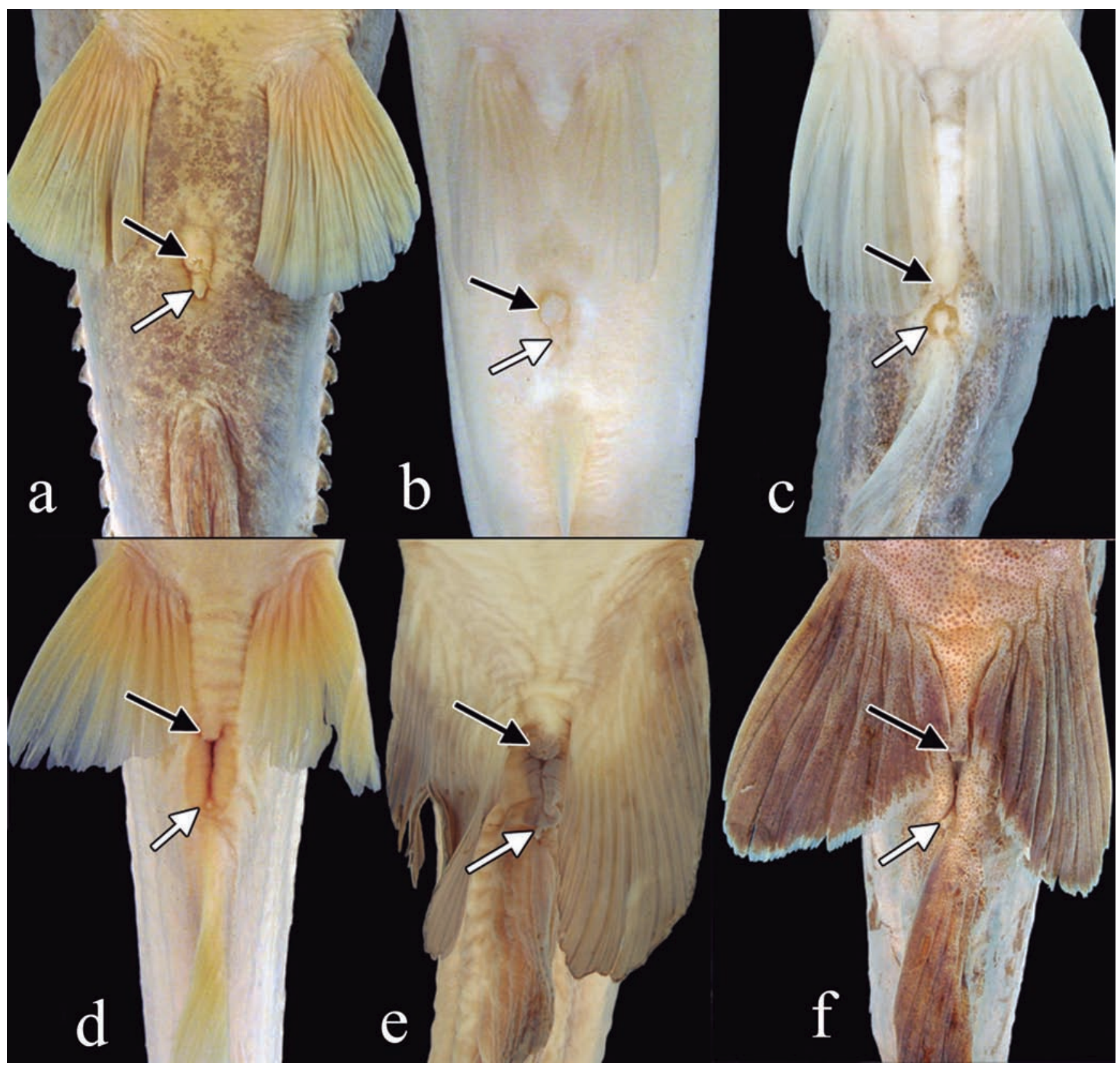

Fig. 19. Anal and urogenital opening in ventral view of females of (a) Franciscodoras marmoratus, MZUSP 95398, $190 \mathrm{~mm}$ SL; (b) Centromochlus heckelii, MZUSP 104793, 106 mm SL; (c) Tatia intermedia, MZUSP 104786, 102 mm SL; (d) Pseudauchenipterus affinis, MZUSP 93092, 112 mm SL; (e) Trachelyopterichthys taeniatus, MZUSP 8496, 113 mm SL; (f) Tetranematichthys wallacei, MZUSP 85497, 191 mm SL. Black arrows indicate anal opening, white arrows indicate urogenital opening. 
"X", with paired anterior processes and a medial constriction (Fig. 20). The mesethmoid is also shaped as an " $X$ " in the auchenipterids Auchenipterus, Entomocorus, Epapterus, Gelanoglanis, and Pseudepapterus, in Astrodoradinae and in the doradids Acanthodoras, Agamyxis, Centrochir, Centrodoras, Franciscodoras, Megalodoras, Orinocodoras, Platydoras, Rhinodoras, and Rhynchodoras (Figs. 22, 24, 30; Soares-Porto, 1998: fig. 5; Royero, 1999: \#9, \#10; Britto, 2002: \#1; Akama, 2004: \#30). However, the mesethmoid is wide and not medially constricted, resulting in a form similar to a square in the Aspredinidae, mochokids Chiloglanis and
Synodontis, all auchenipterids (except Auchenipterus, Entomocorus, Epapterus, Gelanoglanis, and Pseudepapterus), and doradids Doraops, Kalyptodoras, Lithodoras, Pterodoras, and Wertheimeria (Figs. 21, 23, 28, 29, 31; Higuchi, 1992: \#9; Vigliotta, 2008: \#2; Sousa, 2010: \#8). The mesethmoid is shaped as an arrow, medially dilated in all species of Anduzedoras, Doras, Hassar, Hemidoras, Leptodoras, Nemadoras, Ossancora, Oxydoras, Tenellus, and Trachydoras (Fig. 25-27; Higuchi, 1992: \#11).

53. Length of mesethmoid: 0- relatively short, length less than

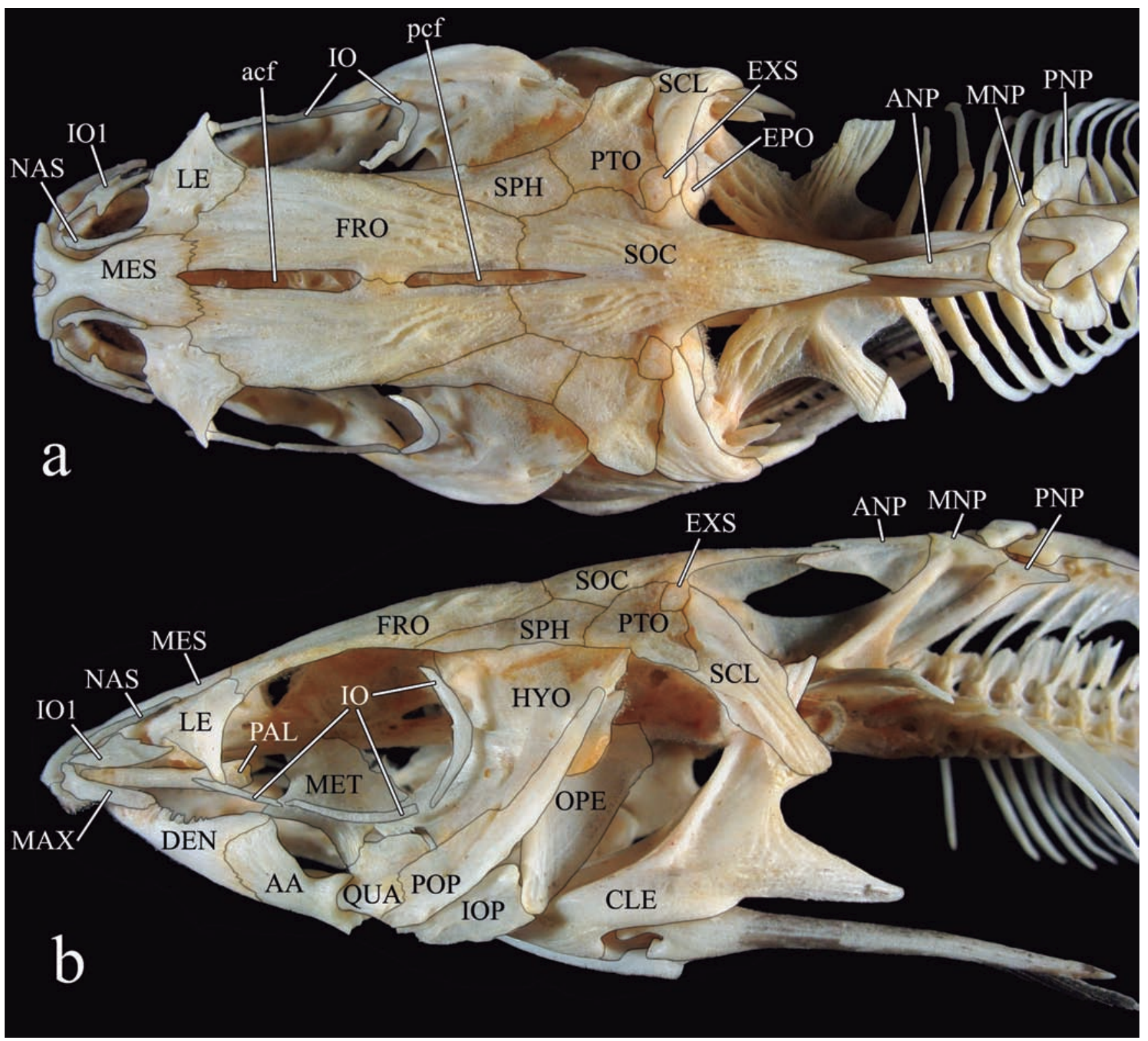

Fig. 20. Skeleton of head and anterior portion of body in Ictalurus punctatus, MZUSP 103256, $155 \mathrm{~mm}$ SL, in dorsal (a) and lateral (b) views. AA anguloarticular, acf anterior cranial fontanel, ANP anterior nuchal plate, CLE cleithrum, DEN dentary, EPO epiotic, EXS extrascapular, FRO frontal, HYO hyomandibula, IO infraorbital, IOP interopercle, LE lateral ethmoid, MAX maxilla, MES mesethmoid, MET metapterygoid, MNP middle nuchal plate, NAS nasal, OPE opercle, PAL autopalatine, pcf posterior cranial fontanel, PNP posterior nuchal plate, POP preopercle, PTO pterotic, QUA quadrate, SCL posttemporal-supracleithrum, SOC parietal-supraoccipital, SPH sphenotic. 


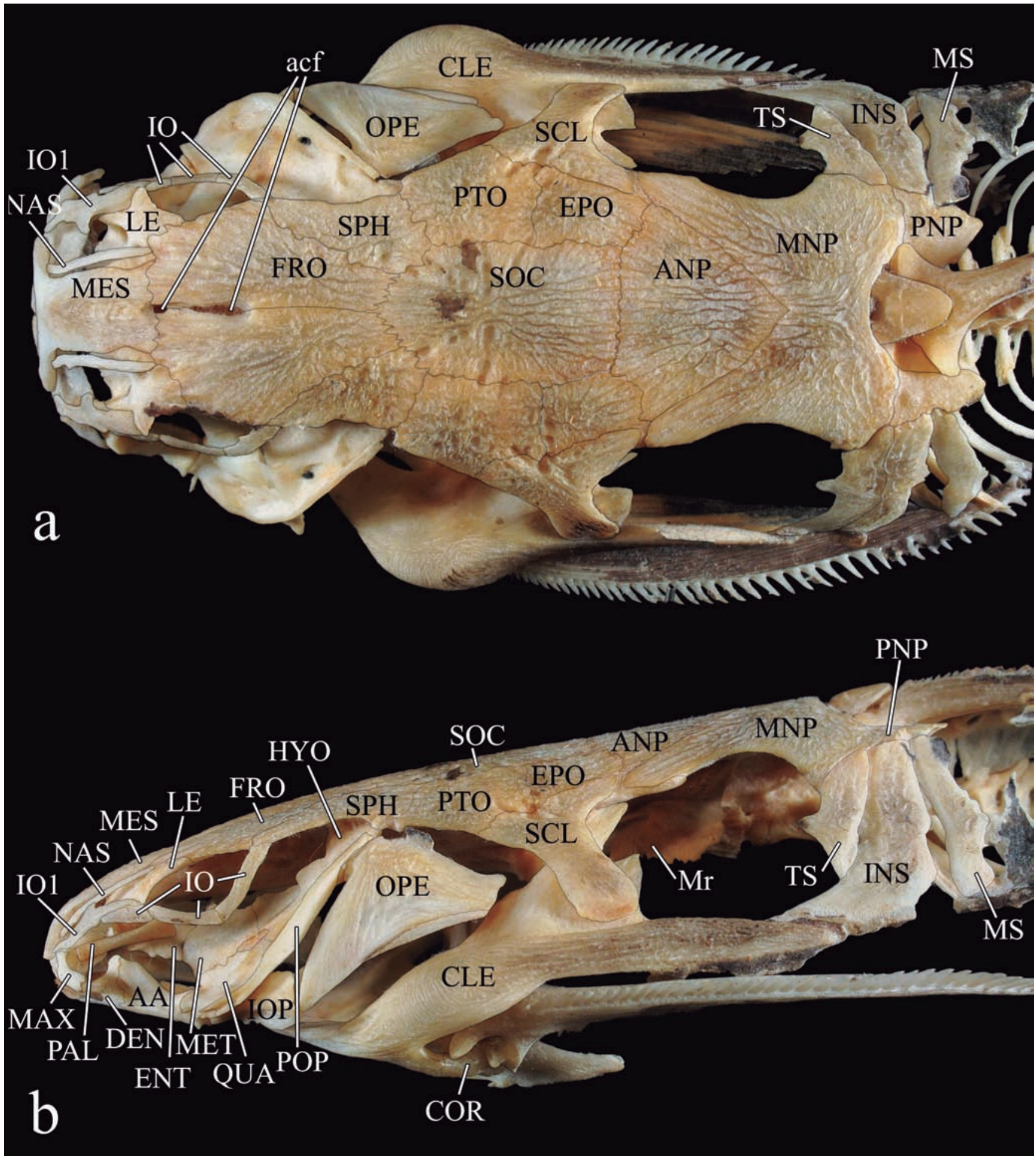

Fig. 21. Head and anterior portion of body in Wertheimeria maculata, MZUSP 93659, $217 \mathrm{~mm}$ SL, in dorsal (a) and lateral (b) views. AA anguloarticular, acf anterior cranial fontanel, ANP anterior nuchal plate, CLE cleithrum, COR coracoid, DEN dentary, ENT entopterygoid, EPO epiotic, FRO frontal, HYO hyomandibula, INS infranuchal scute, IO infraorbital, IOP interopercle, LE lateral ethmoid, MAX maxilla, MES mesethmoid, MET metapterygoid, MNP middle nuchal plate, Mr Müllerian ramus, MS (postinfranuchal) midlateral scutes, NAS nasal, OPE opercle, PAL autopalatine, PNP posterior nuchal plate, POP preopercle, PTO pterotic, QUA quadrate, SCL posttemporal-supracleithrum, SOC parietal-supraoccipital, SPH sphenotic, TS tympanic scutes. 


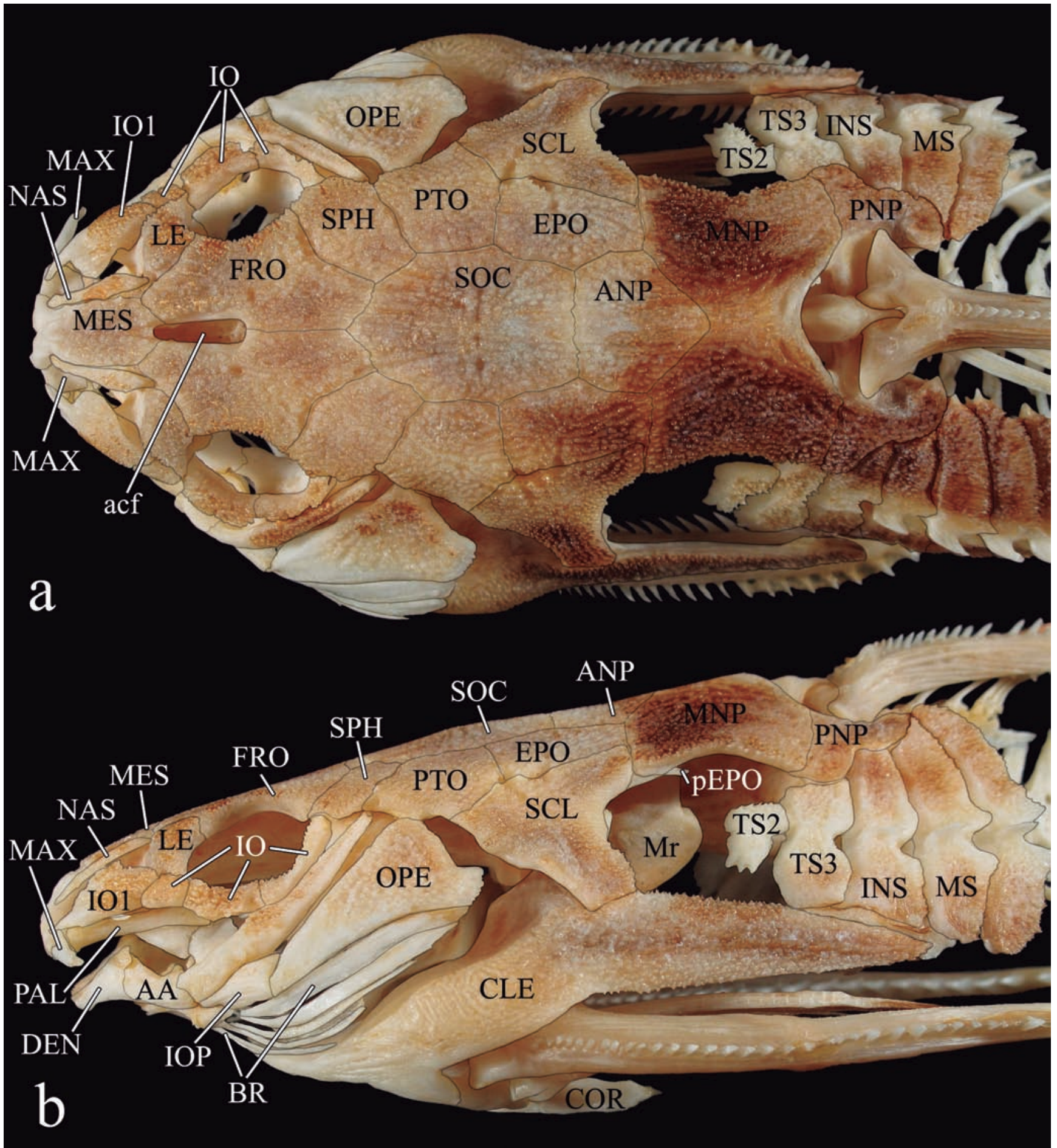

Fig. 22. Head and anterior portion of body in Platydoras armatulus, MZUSP 91686, $151.7 \mathrm{~mm}$ SL, in dorsal (a) and lateral (b) views. AA anguloarticular, acf anterior cranial fontanel, ANP anterior nuchal plate, BR branchiostegal rays, CLE cleithrum, COR coracoid, DEN dentary, ENT entopterygoid, EPO epiotic, FRO frontal, INS infranuchal scute, IO infraorbital, IOP interopercle, LE lateral ethmoid, MAX maxilla, MES mesethmoid, MNP middle nuchal plate, Mr Müllerian ramus, MS (postinfranuchal) midlateral scutes, NAS nasal, OPE opercle, PAL autopalatine, pEPO epiotic process, PNP posterior nuchal plate, PTO pterotic, QUA quadrate, SCL posttemporal-supracleithrum, SOC parietal-supraoccipital, SPH sphenotic, TS tympanic scutes. 


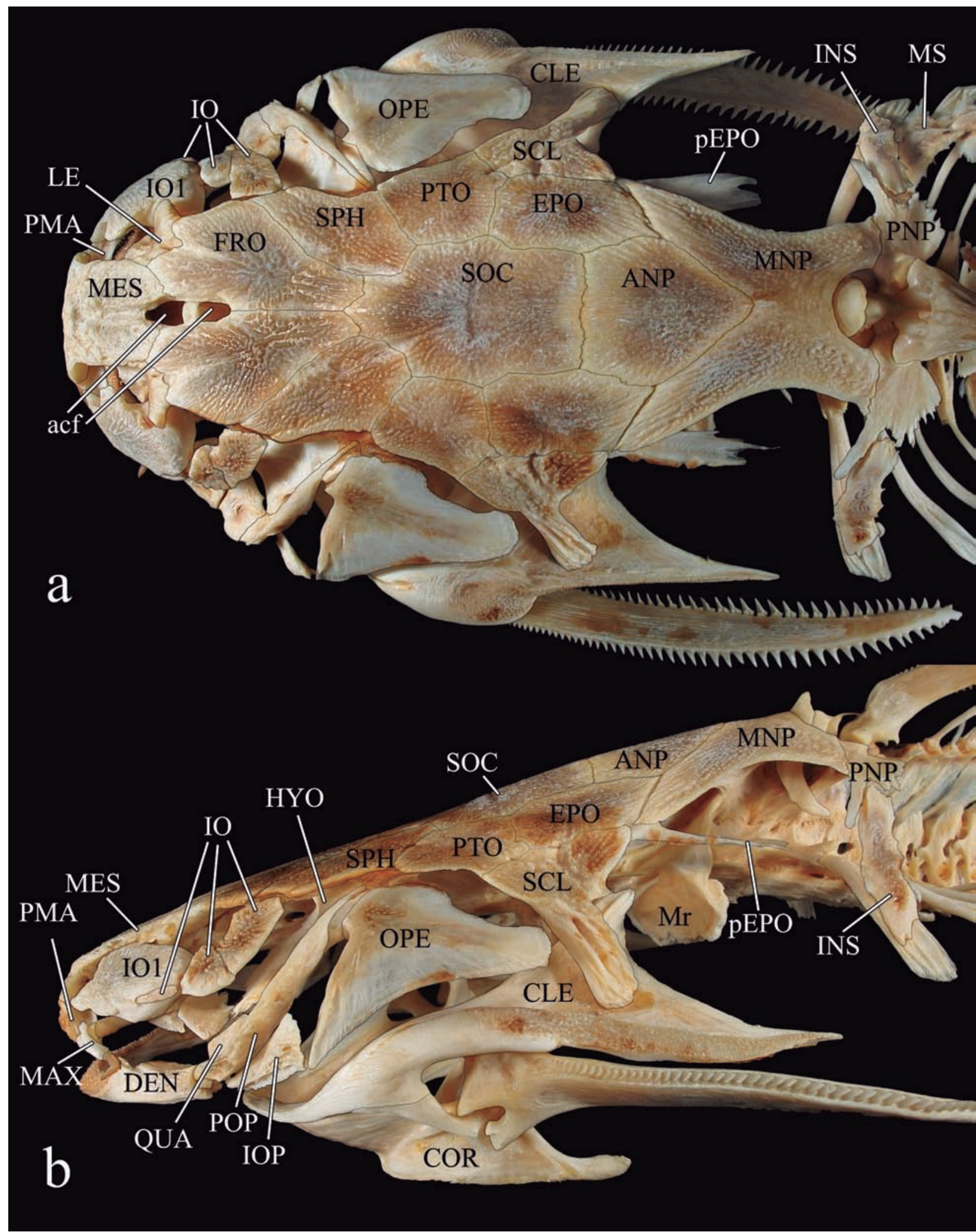

Fig. 23. Head and anterior portion of body in Pterodoras granulosus, MZUSP 91665, 410 mm SL, in dorsal (a) and lateral (b) views. acf anterior cranial fontanel, ANP anterior nuchal plate, CLE cleithrum, COR coracoid, DEN dentary, ENT entopterygoid, EPO epiotic, FRO frontal, HYO hyomandibula, INS infranuchal scute, IO infraorbital, IOP interopercle, LE lateral ethmoid, MAX maxilla, MES mesethmoid, MNP middle nuchal plate, Mr Müllerian ramus, MS (postinfranuchal) midlateral scutes, OPE opercle, pEPO epiotic process, PMA premaxilla, PNP posterior nuchal plate, POP preopercle, PTO pterotic, QUA quadrate, SCL posttemporal-supracleithrum, SOC parietal-supraoccipital, SPH sphenotic. 


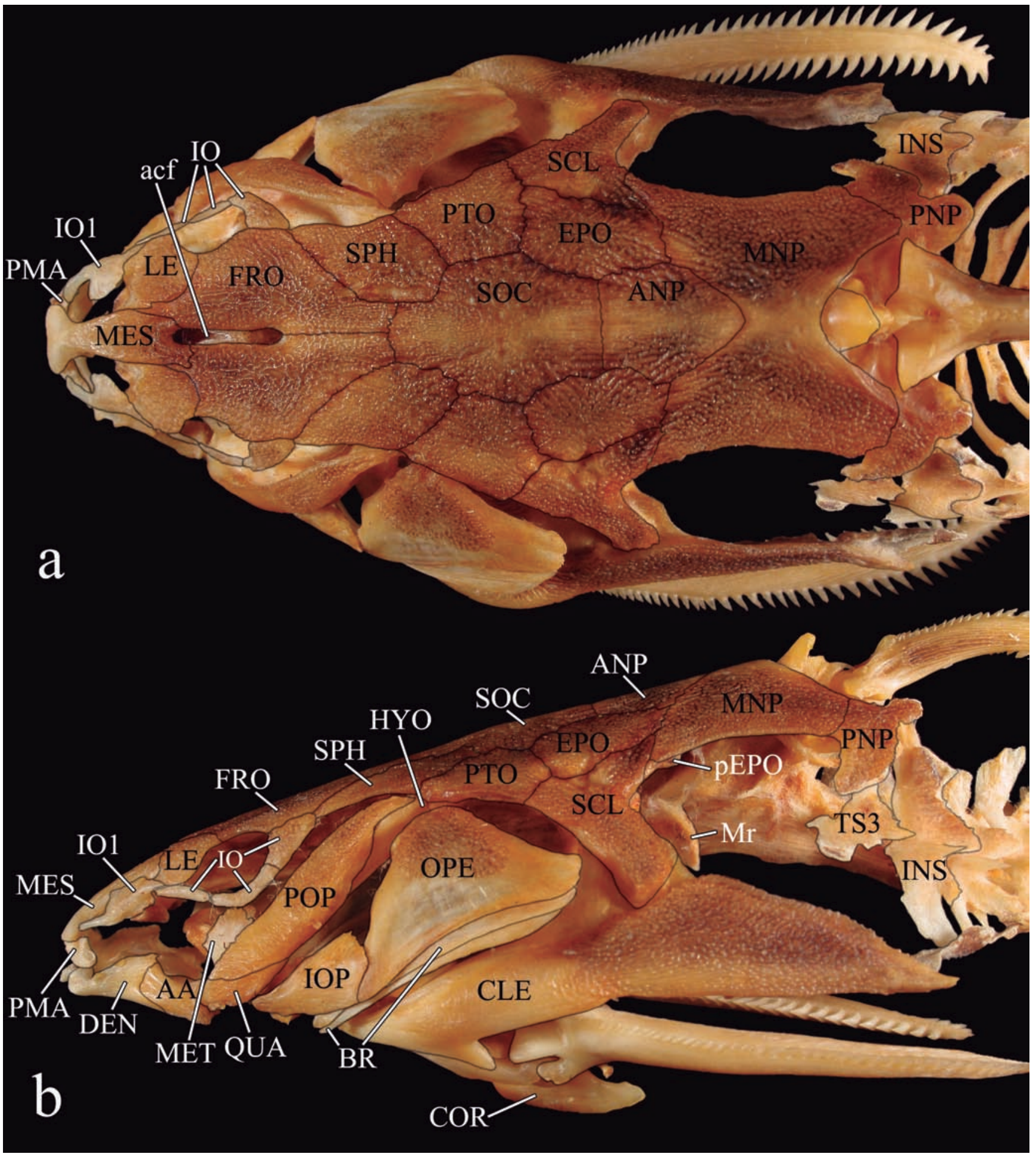

Fig. 24. Head and anterior portion of body in Orinocodoras eigenmanni, FMNH 105276, $193 \mathrm{~mm}$ SL, in dorsal (a) and lateral (b) views. AA anguloarticular, acf anterior cranial fontanel, ANP anterior nuchal plate, BR branchiostegal rays, CLE cleithrum, COR coracoid, DEN dentary, EPO epiotic, FRO frontal, HYO hyomandibula, INS infranuchal scute, IO infraorbital, IOP interopercle, LE lateral ethmoid, MAX maxilla, MES mesethmoid, MET metapterygoid, MNP middle nuchal plate, Mr Müllerian ramus, OPE opercle, PAL autopalatine, pEPO epiotic process, PMA premaxilla, PNP posterior nuchal plate, POP preopercle, PTO pterotic, QUA quadrate, SCL posttemporal-supracleithrum, SOC parietal-supraoccipital, SPH sphenotic, TS tympanic scutes. 
three times width; 1- relatively elongate, length greater than three times width (CI 1.0, RI 1.0).

The mesethmoid is relatively elongate, with length greater than three times its width, in the doradids Anduzedoras, Doras,
Hassar, Hemidoras, Leptodoras, Nemadoras, and Tenellus (Fig. 27; Higuchi, 1992: \#13). The mesethmoid is relatively short, length less than three times its width, in all other examined species (Figs. 20-26, 28-31).

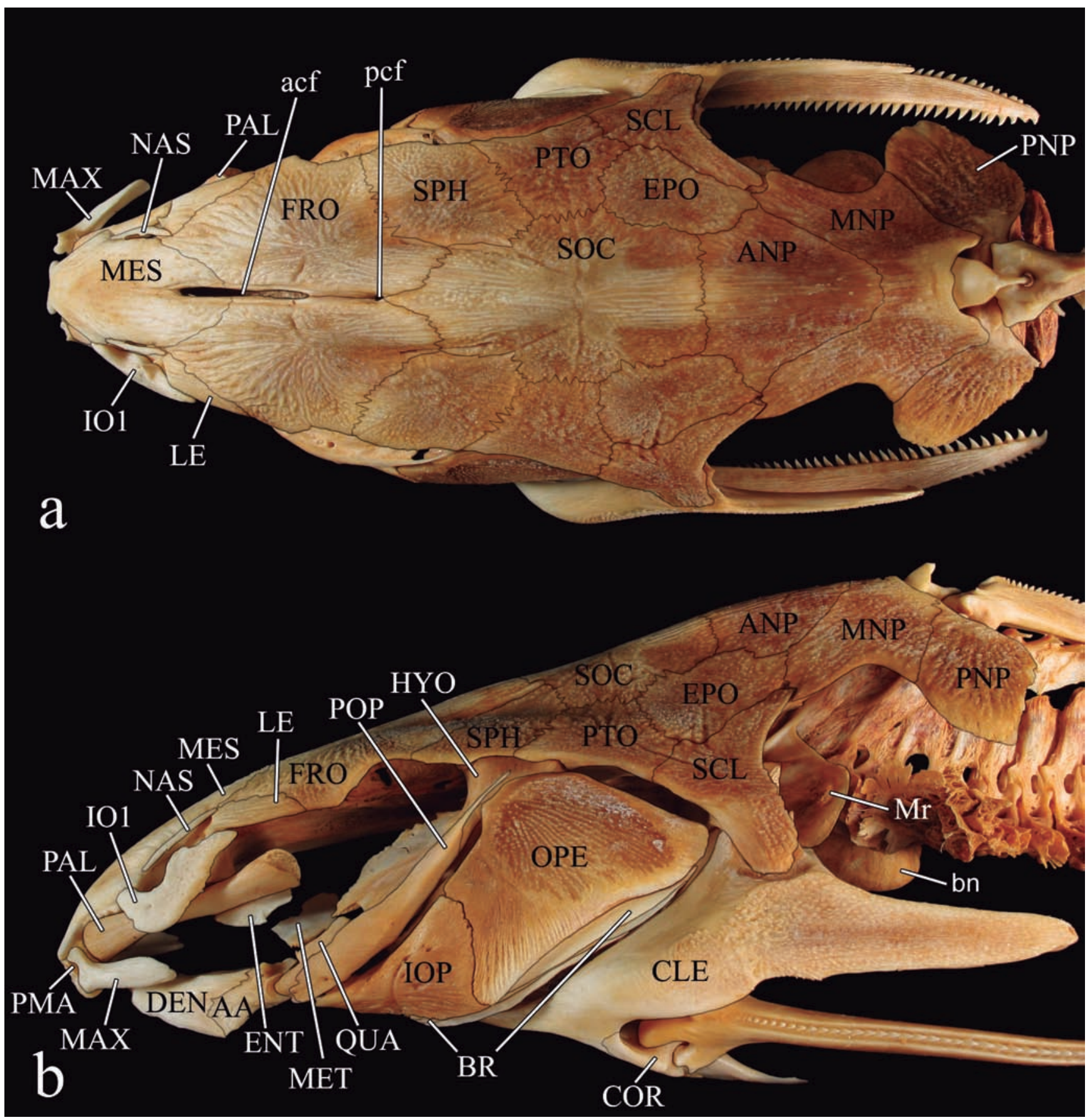

Fig. 25. Head and anterior portion of body in Oxydoras niger, MZUSP 91654, 555 mm SL, in dorsal (a) and lateral (b) views. AA anguloarticular, acf anterior cranial fontanel, ANP anterior nuchal plate, BR branchiostegal rays, bn bony nodule, CLE cleithrum, COR coracoid, DEN dentary, ENT entopterygoid, EPO epiotic, FRO frontal, HYO hyomandibula, IO infraorbital, IOP interopercle, LE lateral ethmoid, MAX maxilla, MES mesethmoid, MET metapterygoid, MNP middle nuchal plate, Mr Müllerian ramus, NAS nasal, no bony nodule, OPE opercle, PAL autopalatine, pcf posterior cranial fontanel, PMA premaxilla, PNP posterior nuchal plate, POP preopercle, PTO pterotic, QUA quadrate, SCL posttemporal-supracleithrum, SOC parietal-supraoccipital, SPH sphenotic, TS tympanic scutes. 


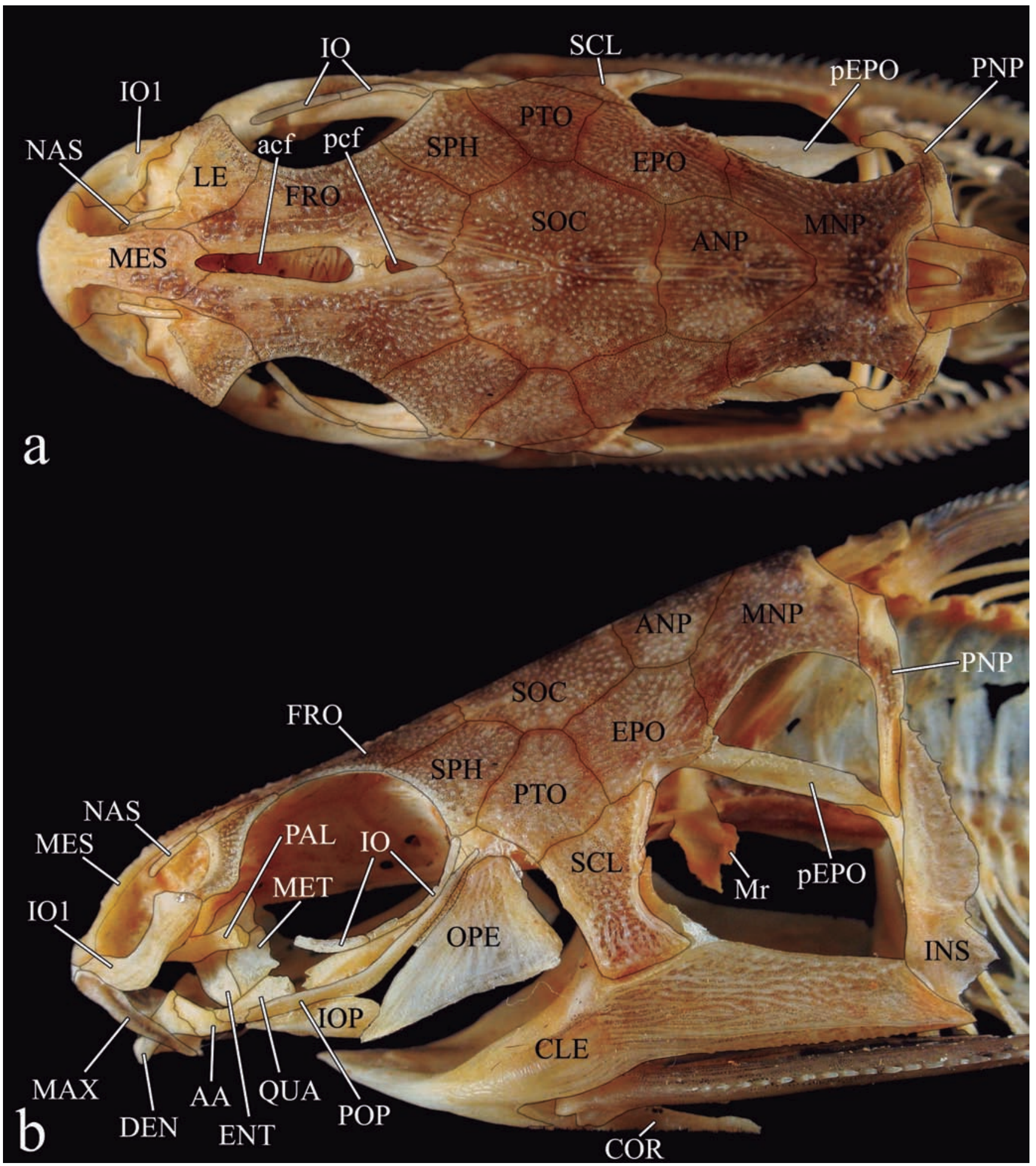

Fig. 26. Head and anterior portion of body in Trachydoras brevis, MZUSP 103087, 75 mm SL, in dorsal (a) and lateral (b) views. AA anguloarticular, acf anterior cranial fontanel, ANP anterior nuchal plate, CLE cleithrum, COR coracoid, DEN dentary, ENT entopterygoid, EPO epiotic, FRO frontal, INS infranuchal scute, IO infraorbital, IOP interopercle, LE lateral ethmoid, MAX maxilla, MES mesethmoid, MET metapterygoid, MNP middle nuchal plate, Mr Müllerian ramus, NAS nasal, OPE opercle, PAL autopalatine, pcf posterior cranial fontanel, pEPO epiotic process, PNP posterior nuchal plate, POP preopercle, PTO pterotic, QUA quadrate, SCL posttemporal-supracleithrum, SOC parietal-supraoccipital, SPH sphenotic. 
54. Anterior portion of mesethmoid: 0- covered by a thin layer of skin, continuous with remaining mesethmoid; 1 - covered by a thick layer of skin, distinguished from remaining mesethmoid by a distinct step (CI 0.250, RI 0.5).
In most catfishes, a thin layer of skin covers the anterior and posterior portions of the mesethmoid (Figs. 20-28, 30-31). However, in the doradids Trachydoras steindachneri, and auchenipterids Liosomadoras, Trachelyopterus,

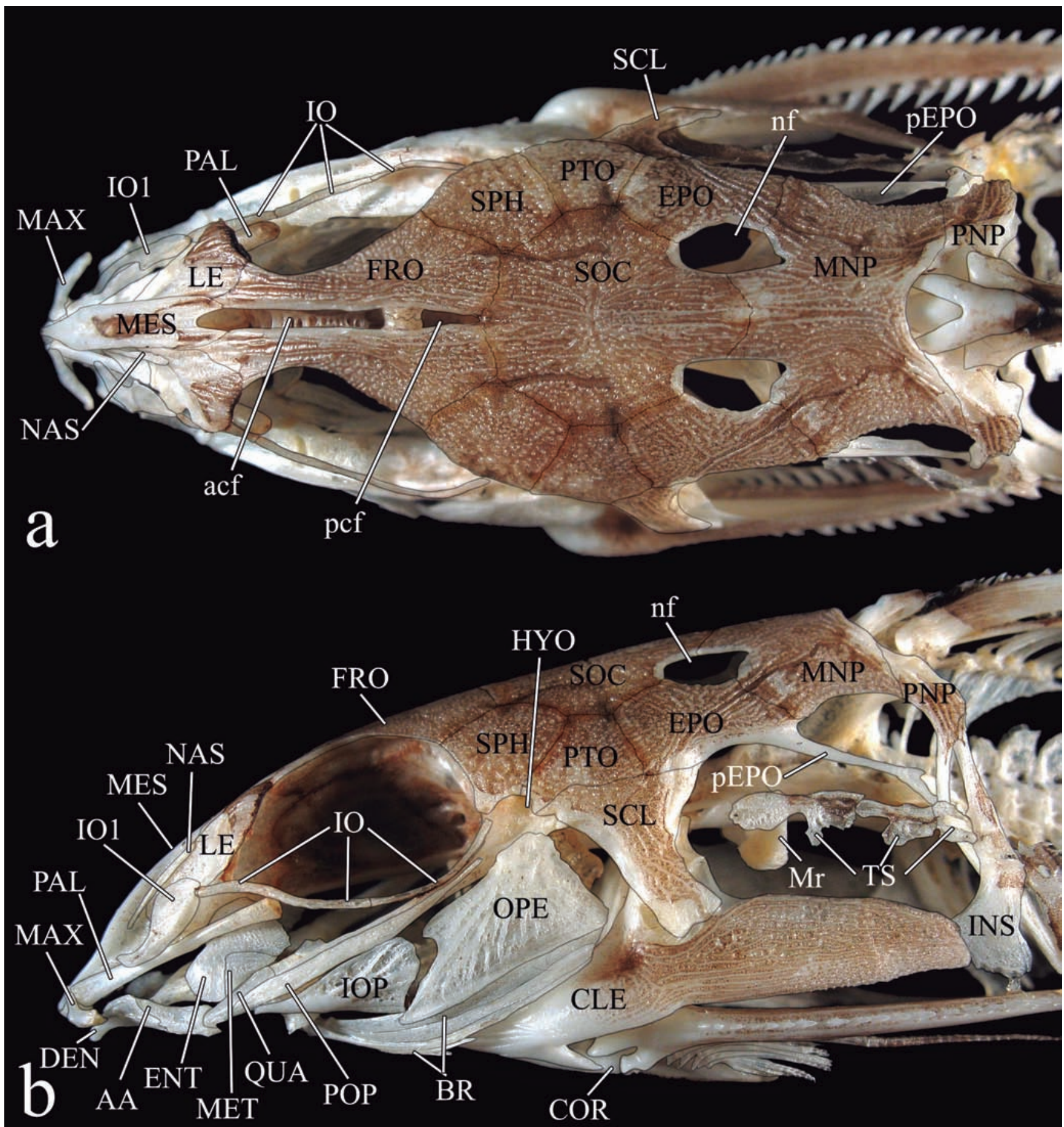

Fig. 27. Head and anterior portion of body in Tenellus ternetzi, MZUSP 103246, 94 mm SL, in dorsal (a) and lateral (b) views. AA anguloarticular, acf anterior cranial fontanel, BR branchiostegal rays, CLE cleithrum, COR coracoid, DEN dentary, ENT entopterygoid, EPO epiotic, FRO frontal, HYO hyomandibula, INS infranuchal scute, IO infraorbital, IOP interopercle, LE lateral ethmoid, MAX maxilla, MES mesethmoid, MET metapterygoid, MNP middle nuchal plate, Mr Müllerian ramus, NAS nasal, nf nuchal foramen, OPE opercle, PAL autopalatine, pcf posterior cranial fontanel, pEPO epiotic process, PNP posterior nuchal plate, POP preopercle, PTO pterotic, QUA quadrate, SCL posttemporal-supracleithrum, SOC parietal-supraoccipital, SPH sphenotic, TS tympanic scutes. 
Trachelyopterichthys, Trachycorystes, and Spinipterus (latter based on Akama \& Ferraris, 2011: fig. 3), the anterior portion of the mesethmoid is covered by a thick layer of skin and distinct from the posterior region, which is covered by a thin layer of skin (Fig. 29; Higuchi, 1992:\#12).

55. Anteroventral keel of mesethmoid (ordered): 0- absent; 1- present, not distinctly developed into a ventral process; 2present, distinctly developed into a distinct ventral process (CI 1.0, RI 1.0).

The anteroventral portion of the mesethmoid in most catfishes is ventrally flattened. However, in the species of Anduzedoras, Doras, Hassar, Hemidoras, Leptodoras, Nemadoras, Ossancora, Oxydoras, Tenellus, and

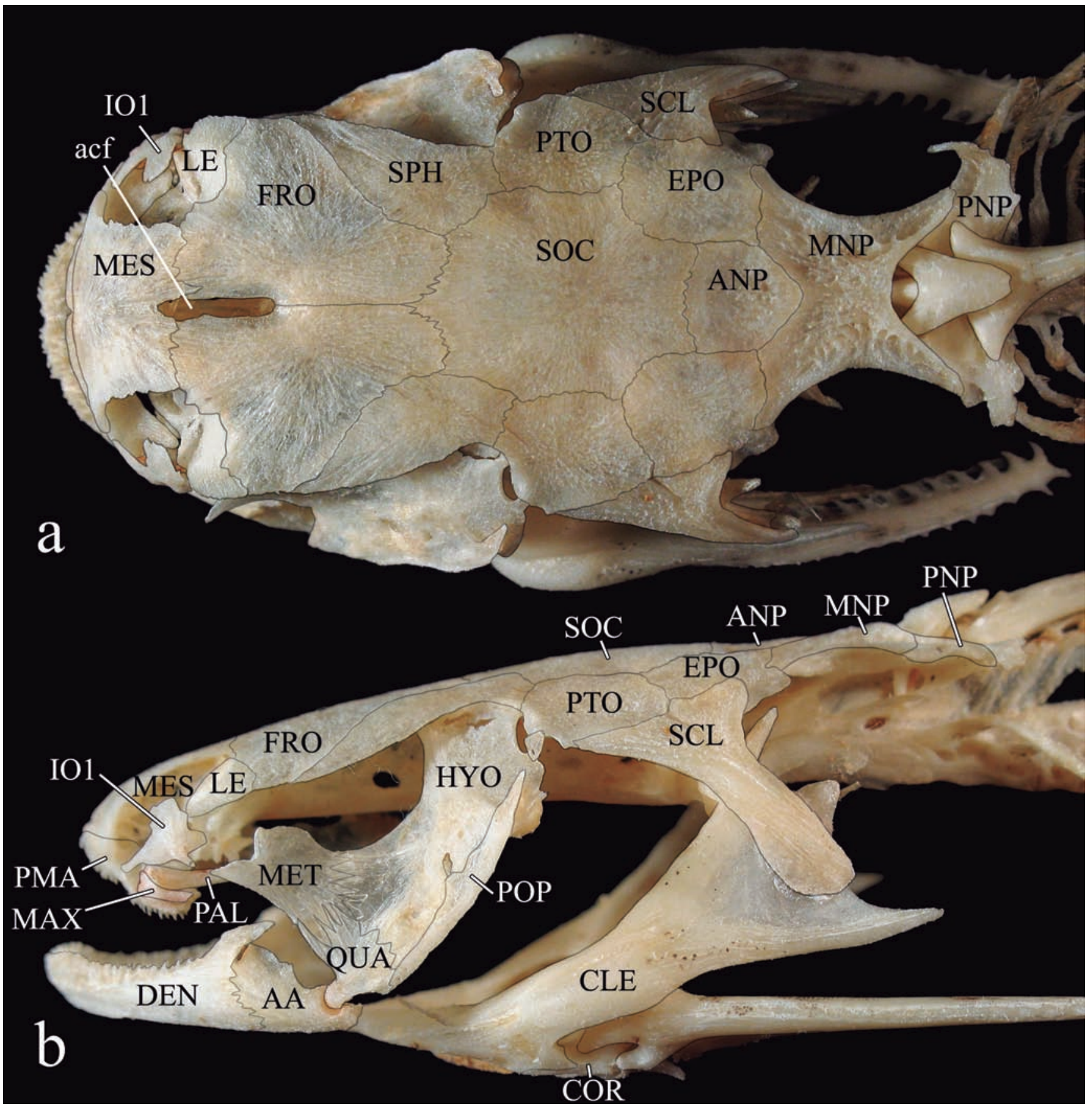

Fig. 28. Head and anterior portion of body in Glanidium melanopterum, MZUSP 64256, 112 mm SL, in dorsal (a) and lateral (b) views. AA anguloarticular, acf anterior cranial fontanel, ANP anterior nuchal plate, CLE cleithrum, COR coracoid, DEN dentary, EPO epiotic, FRO frontal, HYO hyomandibula, IO infraorbital, IOP interopercle, LE lateral ethmoid, MAX maxilla, MES mesethmoid, MET metapterygoid, MNP middle nuchal plate, PAL autopalatine, PMA premaxilla, PNP posterior nuchal plate, POP preopercle, PTO pterotic, QUA quadrate, SCL posttemporal-supracleithrum, SOC parietal-supraoccipital, SPH sphenotic. 
Trachydoras there is an anteroventral keel on the mesethmoid to which are connected the reduced premaxillae (Fig. 32a). Furthermore, in the doradid Trachydoras this keel is developed into a distinct ventral process (Fig. 32b).
56. Shape of anterior cranial fontanel: 0- elongate; 1 - rounded (CI 0.25, RI 0.0).

The anterior cranial fontanel of most catfishes is present as a large rounded opening in larvae and small juveniles, and

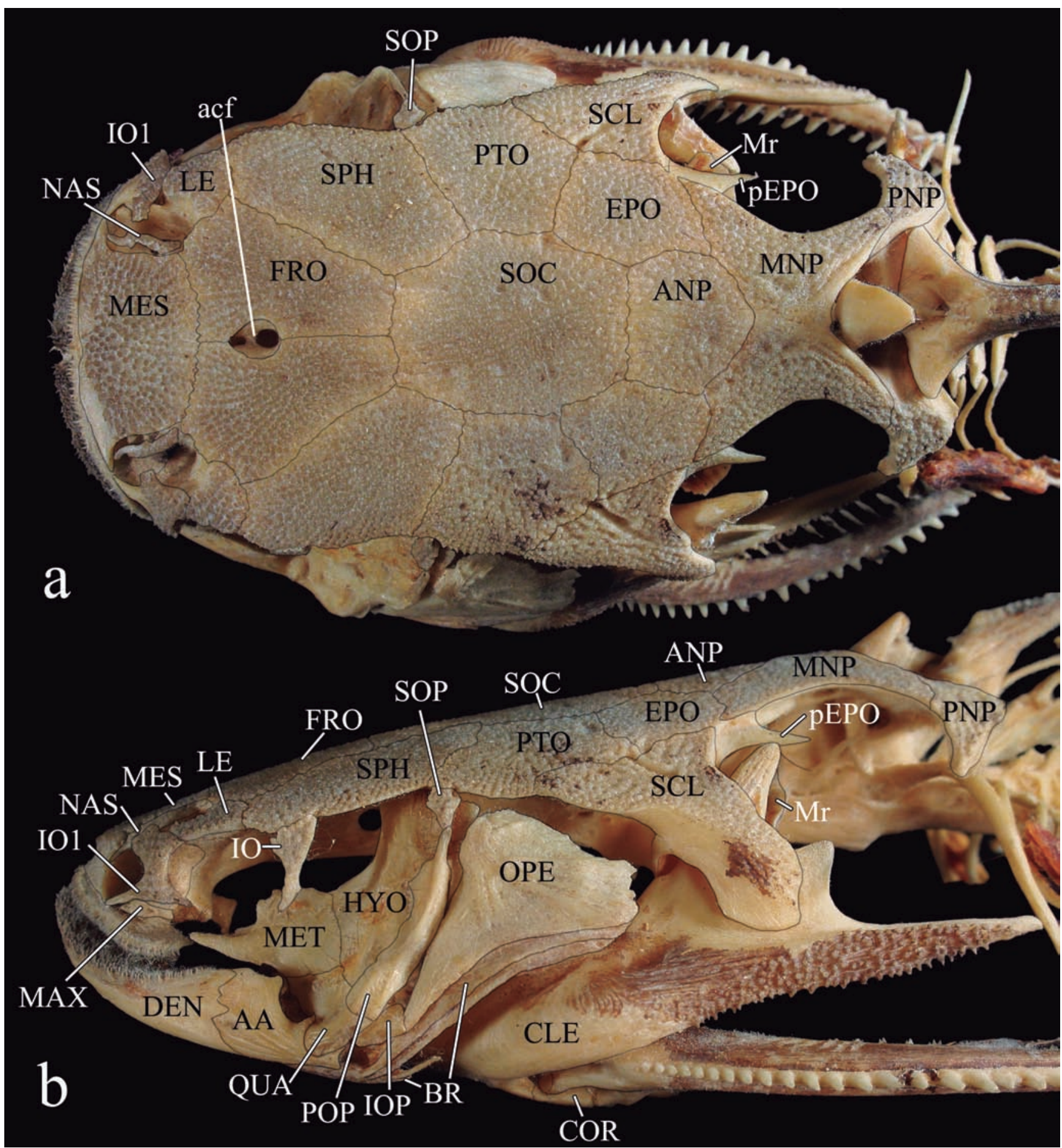

Fig. 29. Head and anterior portion of body in Trachycorystes trachycorytes, MZUSP 104547, 180 mm SL, in dorsal (a) and lateral (b) views. AA anguloarticular, acf anterior cranial fontanel, ANP anterior nuchal plate, BR branchiostegal rays, CLE cleithrum, COR coracoid, DEN dentary, EPO epiotic, FRO frontal, HYO hyomandibula, IO infraorbital, IOP interopercle, LE lateral ethmoid, MAX maxilla, MES mesethmoid, MET metapterygoid, MNP middle nuchal plate, Mr Müllerian ramus, NAS nasal, OPE opercle, pEPO epiotic process, PNP posterior nuchal plate, POP preopercle, PTO pterotic, QUA quadrate, SCL posttemporal-supracleithrum, SOC parietal-supraoccipital, SPH sphenotic. 


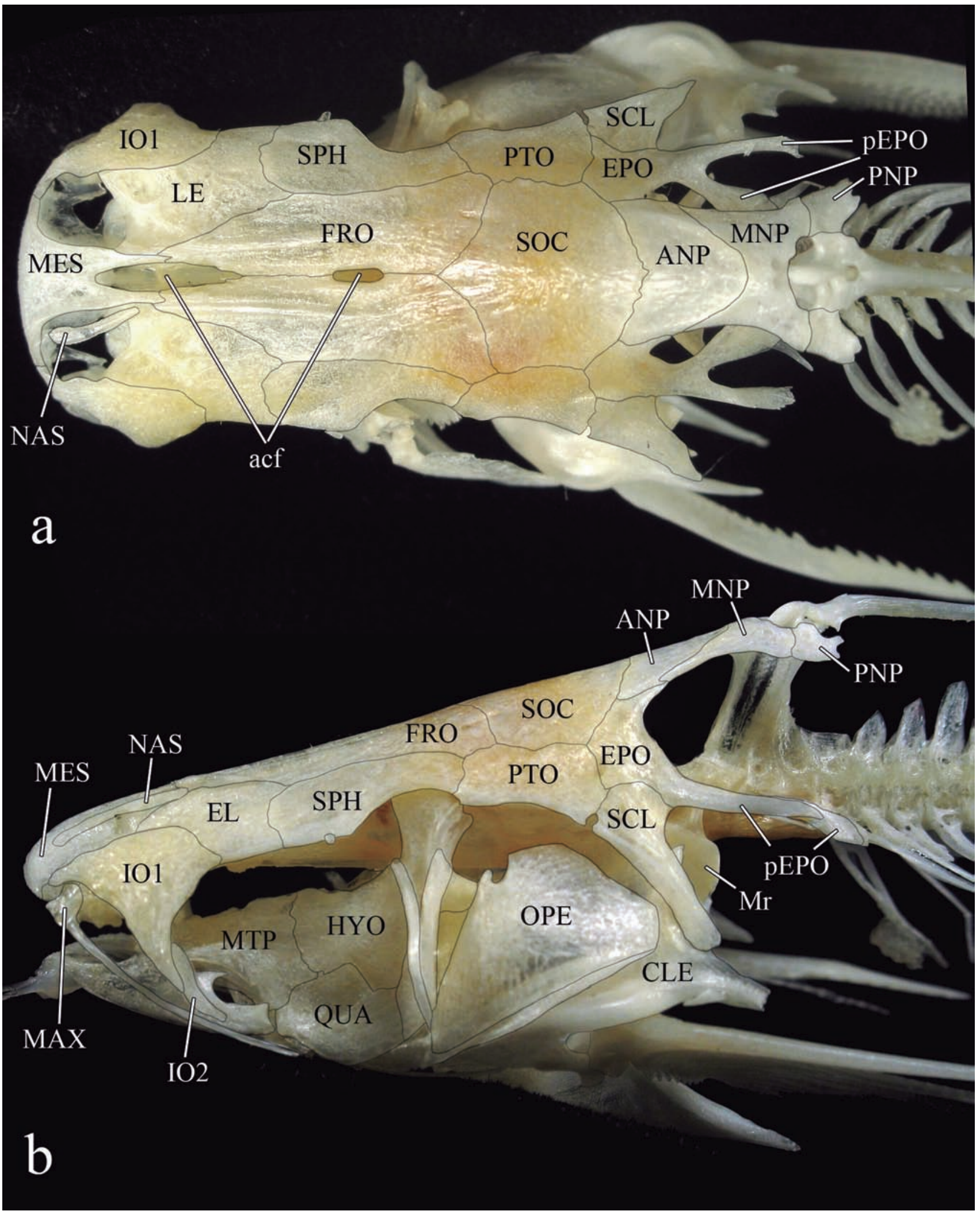

Fig. 30. Head and anterior portion of body in Auchenipterus nuchalis, MZUSP 97375, 120 mm SL, in dorsal (a) and lateral (b) views. acf anterior cranial fontanel, ANP anterior nuchal plate, CLE cleithrum, EPO epiotic, FRO frontal, HYO hyomandibula, IO infraorbital, LE lateral ethmoid, MAX maxilla, MES mesethmoid, MET metapterygoid, MNP middle nuchal plate, Mr Müllerian ramus, NAS nasal, OPE opercle, pcf posterior cranial fontanel, pEPO epiotic process, PNP posterior nuchal plate, PTO pterotic, QUA quadrate, SCL posttemporal-supracleithrum, SOC parietal-supraoccipital, SPH sphenotic. 


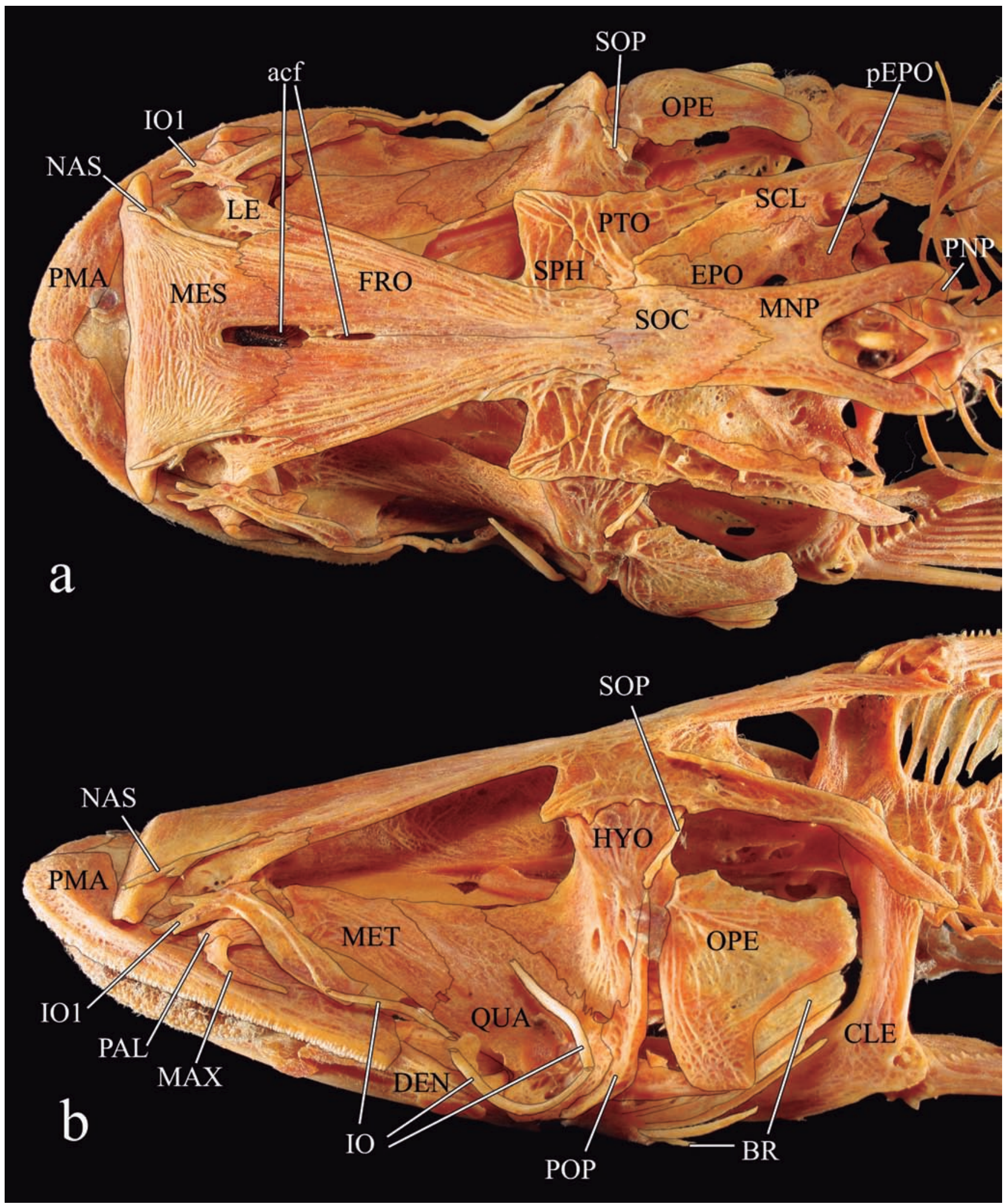

Fig. 31. Head and anterior portion of body in Ageneiosus inermis, MZUSP 91661, $320 \mathrm{~mm}$ SL, in dorsal (a) and lateral (b) views. acf anterior cranial fontanel, BR branchiostegal rays, CLE cleithrum, DEN dentary, EPO epiotic, FRO frontal, HYO hyomandibula, IO infraorbital, LE lateral ethmoid, MAX maxilla, MES mesethmoid, MET metapterygoid, MNP middle nuchal plate, NAS nasal, OPE opercle, PAL autopalatine, pEPO epiotic process, PMA premaxilla, PNP posterior nuchal plate, POP preopercle, PTO pterotic, QUA quadrate, SCL posttemporal-supracleithrum, SOC parietal-supraoccipital, SPH sphenotic. 
becomes an elongate slit enclosed anteriorly by the mesethmoid and posteriorly by the frontals in large juveniles and adults (Figs. 20-31). However, in the Aspredinidae, auchenipterids Trachelyichthys and Spinipterus (Royero, 1999: \#4; Akama \& Ferraris, 2011), and the mochokid Mochokus the anterior cranial fontanel is a relatively large round opening in the adults. That feature is probably paedomorphic in those taxa. The fontanel was described as absent in Gelanoglanis stroudi (Ferraris, 1988: \#N6; SoaresPorto, 1998; Soares-Porto et al., 1999) for specimens of 23.9$24.6 \mathrm{~mm}$ SL. However, in the only cleared and stained specimen herein examined and tentatively identified as conspecific to G. stroudi, a round opening is present between the frontals.

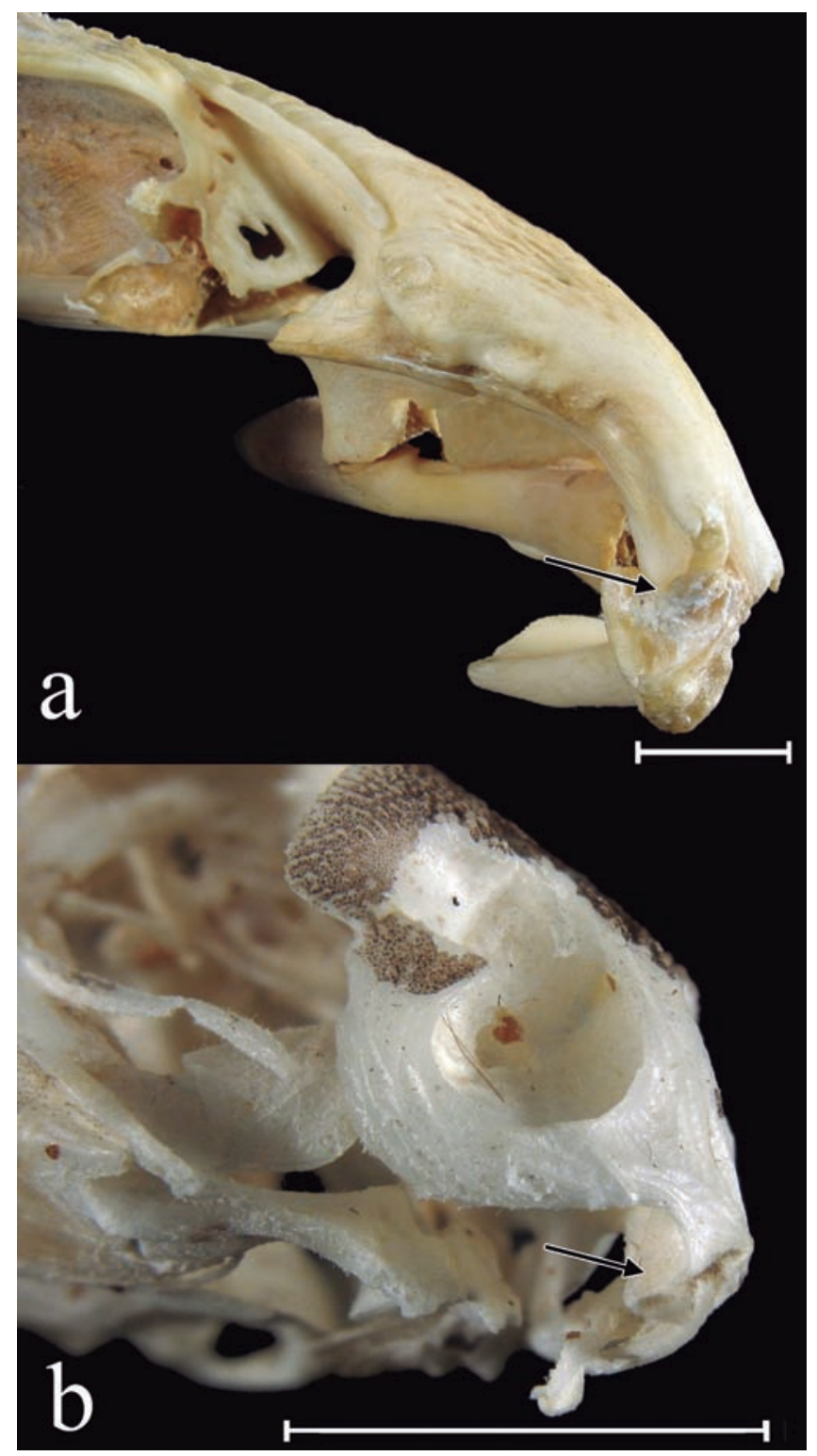

Fig. 32. Anterior portion of head in ventrolateral view of (a) Oxydoras niger, MZUSP 91654, 555.0 mm SL; (b) Trachydoras brevis, MZUSP 103087, 74 mm SL. Arrows indicate anteroventral keel of mesethmoid. Scale bars equal $10 \mathrm{~mm}$.
These conflicting observations may be due to the different sizes of the specimens examined. This character is coded as missing data for Gelanoglanis, considering that the anterior cranial fontanel is absent in adults.

57. Anterior cranial fontanel (unordered): 0- undivided; 1divided into two openings separated by a narrow bridge between frontals; 2- divided into two openings separated by a wide bridge between frontals (CI 0.25, RI 0.4).

In most examined taxa, the anterior cranial fontanel is a single continuous opening (Figs 20, 22, 24-28). However, in the auchenipterids Ageneiosus inermis, Auchenipterichthys, Liosomadoras, Tetranematichthys, Tocantinsia, Trachelyopterichthys, Trachelyopterus, Trachycorystes and some specimens of Centromochlus, and Tatia (Figs. 29, 31; Royero, 1999: \#3; Akama, 2004: \#12, \#13, \#14), and doradids Agamyxis, Anadoras, and some specimens of Acanthodoras, Kalyptodoras, Platydoras, Pterodoras granulosus, and Wertheimeria, the anterior cranial fontanel is divided into two openings by a thin bridge between frontals (Figs. 21, 23; Eigenmann, 1925: 284; Higuchi, 1992: \#10, \#A19; Sousa, 2010: \#14). In the auchenipterid Auchenipterus, the anterior cranial fontanel is divided into two openings by a wide bridge between frontals (Fig. 30). This character was coded as polymorphic $(0,1)$ for the auchenipterids Tatia and Centromochlus, and doradids Acanthodoras, Kalyptodoras, Platydoras armatulus, Pterodoras granulosus, and Wertheimeria.

58. Posterior cranial fontanel (ordered): 0 - large; 1- reduced to a small opening; 2- completely occluded (CI 0.125, RI 0.75).

Among examined species, the posterior cranial fontanel is large in the Amphiliidae, ariid Galeichthys, Aspredinidae, Claroteidae, Diplomystidae, Ictaluridae (Lundberg, 1970: \#16), Nematogenyidae, Pangasiidae, Siluridae, and doradids Anduzedoras, Hassar, Leptodoras, Nemadoras hemipeltis, Tenellus, and Trachydoras (Higuchi, 1992: \#17) (Figs. 20, 26, 27; Higuchi, 1992: \#31). The ariid Genidens (Marceniuk et al., 2012: \#27), mochokid Mochokus (Vigliotta, 2008: 6), and doradids Nemadoras elongatus, $N$. humeralis and Oxydoras have the posterior fontanel reduced to a small opening (Fig. 25). The posterior cranial fontanel is completely occluded in the Auchenipteridae, Erethistidae, Heptapteridae, Malapteruridae, Pimelodidae, Pseudopimelodidae, Sisoridae, mochokid Chiloglanis disneyi (Vigliotta, 2008: \#6), and remaining species of Doradidae (Figs. 21-24, 28-31).

59. Dorsal face of lateral ethmoid: 0- not participating in cephalic shield; 1- participating in cephalic shield (CI 0.143, RI 0.25).

The lateral ethmoid, a paired bone of the cranium, does not participate in the cephalic shield in most catfishes. However, in several species of the Amphiliidae, Ariidae, Aspredinidae, Claroteidae, Erethistidae, Ictaluridae, Mochokidae, Pimelodidae, Siluridae, and Sisoridae, the dorsal face of the lateral ethmoid participates in the cephalic shield 
(Figs. 20-31; Alexander, 1965: 97). The same condition is present in all species of the Doradidae and of Auchenipteridae, except Centromochlus heckelii, Pseudauchenipterus and Pseudotatia (among examined species). Higuchi (1992: \#15) considered the dorsal face of the lateral ethmoid excluded from the cephalic shield in the doradid Wertheimeria, an observation not corroborated herein (Fig. 21). Similarly, the specimen of the auchenipterid Gelanoglanis stroudi illustrated in Soares-Porto (1998) does not have the lateral ethmoid participating in the cephalic shield. However, the specimen of Gelanoglanis examined herein has the lateral ethmoid partially participating in the cephalic shield; this character was coded as 1 for Gelanoglanis.

60. Fenestra between lateral ethmoid and frontal: 0- absent; 1- present (CI 0.2, RI 0.714).

Among examined taxa, there is a fenestra between the lateral ethmoid and frontal only in the Amphiliidae, Ariidae (Marceniuk et al., 2012: \#3), Claroteidae, Diplomystidae, Heptapteridae, Ictaluridae, Mochokidae, Pangasiidae, Pimelodidae, Siluridae (de Pinna, 1993: \#68; Britto, 2002: \#6), and the auchenipterid Pseudauchenipterus. This character was coded as missing data for the auchenipterids Pseudotatia and Spinipterus.

61. Spines on lateral border of lateral ethmoid: 0 - absent; 1present (CI 0.5, RI 0.0).

The lateral border of the lateral ethmoid is smooth or granulated in most catfishes. However, the doradids Agamyxis, Scorpiodoras and some specimens of Acanthodoras have spines on the lateral border of the lateral ethmoid (Higuchi, 1992: \#14, \#A15; Sousa, 2010: \#16; Sousa \& Birindelli, 2011). This character was coded as polymorphic for Acanthodoras.

62. Lateral process of sphenotic: 0 - absent; 1 - present (CI 0.25 , RI 0.833).

Among examined species, the sphenotic has a distinct lateral process only in the Amphiliidae, Malapteruridae, auchenipterids Ageneiosus and Tetranematichthys, and doradids Anduzedoras, Doras, Hassar, Leptodoras, and Tenellus (Figs. 27, 31; Royero, 1999: \#12; Akama, 2004: \#31).

63. Lateroposterior border of sphenotic: 0- slightly concave, not exposing part of the articulation between hyomandibula and sphenotic; 1- distinctly concave, exposing part of the articulation between hyomandibula and sphenotic (CI 0.5, RI 0.857).

In the auchenipterids Ageneiosus, Auchenipterus, Glanidium, Entomocorus, Epapterus, Pseudepapterus, and Tetranematichthys, the lateroposterior border of the sphenotic is distinctly concave, exposing part of the articulation between sphenotic and hyomandibula (Figs. 28, 30, 31; Royero, 1999: \#20; Akama, 2004: \#34), whereas it is only slightly concave in other examined species (Figs. 20-27, 29).
64. Frontal: 0- participating in orbital margin; 1 - not participating in orbital margin (CI 0.333, RI 0.778).

The orbital margin is formed by the lateral ethmoid, sphenotic and infraorbitals in the auchenipterids Asterophysus, Auchenipterichthys, Auchenipterus, Epapterus, Liosomadoras, Pseudepapterus, Trachelyopterichthys, Trachelyopterus, and Trachycorystes (Figs. 29, 30; Britski, 1972: 13; Ferraris, 1988: \#N8; Higuchi, 1992: \#A21, \#34; Royero, 1999: \#1; Britto, 2002: \#5; Akama, 2004: \#17), whereas it is formed by the frontal, lateral ethmoid, infraorbitals, and sphenotic in other catfishes (Figs. 20-28, 31).

65. Lateral ethmoid: 0- participating in orbital margin; 1- not participating in orbital margin (CI 1.0, RI 1.0).

In the doradid Oxydoras, the orbit is displaced posteriorly, and formed by the frontals, sphenotic and infraorbitals (Fig. 25; Alexander, 1965; Higuchi, 1992: \#A21, \#A34). In all other examined species, the lateral ethmoid participates in the orbital taxa (Figs. 20-31).

66. Ventral process of pterotic: 0 - absent; 1 - present (CI 0.5 , RI0.0).

The pterotic in mochokids Mochokiella, Microsynodontis, and Synodontis possesses a distinct ventral process (Vigliotta, 2008:\#11), which is absent in other examined taxa (Figs. 20-31).

67. Fenestra between parietal-supraoccipital, pterotic, and sphenotic: 0- absent; 1 - present (CI and RI inapplicable).

Among examined species, the auchenipterid Pseudepapterus is the only one with a fenestra between the parietal-supraoccipital, pterotic, and sphenotic.

68. Posterior process of parietal-supraoccipital: 0- present; 1absent (CI 1.0, RI 1.0).

The posterior process of the parietal-supraoccipital is present in most catfishes (Fig. 20). However, it is absent in the Auchenipteridae, Doradidae, and Mochokidae (Figs. 2131; Royero, 1999: \#22). The Malapteruridae have the posterior process of the parietal-supraoccipital present but truncate. Diogo (2004: \#131) considered the posterior process of parietal-supraoccipital to be absent in the Malapteruridae; and this shared absence to be a putative synapomorphy of a monophyletic clade comprising the Auchenipteridae, Doradidae, Malapteruridae, and Mochokidae.

69. Sphenotic and parietal-supraoccipital: 0 - in contact; 1 not in contact (CI 0.333, RI 0.0).

In the auchenipterids Auchenipterus and Epapterus the frontal is extended posteriorly, reaching the pterotic, and leaving the sphenotic and parietal-supraoccipital separate (Fig. 30; Chardon, 1968; Britski, 1972: 13; Ferraris, 1988: \#N10; Royero, 1999: \#2, \#18; Akama, 2004: \#19, \#26). The same condition is present in the Malapteruridae (Mo, 1991; Britto, 2002: \#7; Diogo, 2004: \#97; de Pinna et al., 2007: \#34). In all 
other examined species, the posteromedial margin of the sphenotic contacts the parietal-supraoccipital (Figs. 20-29, 31).

70. Accessory dermal ossification between frontal, sphenotic and parietal-supraoccipital: 0- absent; 1- present (CI and RI inapplicable).

Among examined species, only the auchenipterid Entomocorus has an accessory dermal ossification between the frontal, sphenotic and parietal-supraoccipital (Britski, 1972: 14; Ferraris, 1988: \#N13; Akama, 2004: \#22). This character was coded as missing data for the auchenipterid Spinipterus.

71. Accessory dermal ossification between sphenotic, pterotic, and parietal-supraoccipital: 0 - absent; 1 - present (CI and RI inapplicable).

Among examined species, only the auchenipterid Asterophysus has an accessory dermal ossification between the sphenotic, pterotic and parietal-supraoccipital (Britski, 1972: 14; Ferraris, 1988: \#N14; Akama, 2004: \#21). This character was coded as missing data for the auchenipterid Spinipterus.

72. Vomer: 0- present; 1- absent (CI and RI inapplicable).

The vomer is present on the ventral face of the cranium in most catfishes (Fig. 33). However, in the examined specimen of the auchenipterid Gelanoglanis the vomer is absent, corroborating the observation of Ferraris (1988: \#N11), a condition not mentioned in Soares-Porto (1998) and SoaresPorto et al. (1999). This character was coded as missing data for the auchenipterid Spinipterus.

73. Shape of vomer: 0 - shaped as a " $T$ ", with distinct anterior processes; 1- shaped as an "I", with rudimentary anterior processes (CI 0.25, RI 0.914).

Most catfishes have a T-shaped vomer with distinct anterior processes (Fig. 33a; Lundberg, 1970). However, the vomer is shaped as an "I", with rudimentary lateral processes anteriorly in the Diplomystidae (Arratia, 1992: \#50), Malapteruridae, Nematogenyidae, species of Anduzedoras, Doras, Hassar, Hemidoras, Leptodoras, Nemadoras, Ossancora, Tenellus, and Trachydoras (Higuchi, 1992: \#14), and auchenipterids Ageneiosus and Tetranematichthys (Fig. 33b; Britski, 1972: 23; Ferraris, 1988: \#N18; Walsh, 1990: \#3; Akama, 2004: \#24). Soares-Porto (1998: \#11) described the vomer as I-shaped in two species of Centromochlus not included in the present study. This character was coded as inapplicable for the auchenipterid Gelanoglanis, which lacks the vomer; and as missing data for the auchenipterid Spinipterus.

74. Vomerian teeth: 0- absent; 1- present (CI 0.25, RI 0.4).

Some catfishes, including the Diplomystidae, Claroteidae, Pangasiidae, Pimelodidae, Siluridae, and ariid Galeichthys, have vomerian teeth (Lundberg, 1970; de Pinna, 1993: \#60; Britto, 2002: \#31; de Pinna et al., 2007: \#37; Marceniuk et al., 2012: \#53). Although specimens of Auchenipteridae and
Doradidae herein examined lack this feature, Mees (1974: 66) mentioned their presence in Tatia intermedia, Royero (1999: \#32) mentioned it in an undescribed species of Tatia, Akama (2004: \#52) in Asterophysus, and Sarmento-Soares \& MartinsPinheiro (2008: 519) reported it in Tatia gyrina and $T$. intermedia. This character was coded as inapplicable for the auchenipterid Gelanoglanis, which lacks the vomer; as missing data for the auchenipterid Spinipterus, and as polymorphic for the auchenipterid Tatia intermedia.

\section{Accessory tooth plate on vomer: 0 - absent; 1 - present (CI} 0.5, RI 0.667).

In the Ariidae, Claroteidae, $†$ Hypsidoridae, Pangasiidae and Schilbeidae, there is an accessory tooth plate associated with the vomer (Ferraris, 1988: \#J10; de Pinna, 1993: \#72; Royero, 1999: \#32; Britto, 2002: \#32; Akama, 2004: \#52; Marceniuk et al., 2012: \#56). That plate is absent in other examined taxa (Fig. 33). This character was coded as missing data for the auchenipterid Spinipterus.

76. Lateroventral extension of orbitosphenoid: 0 - absent; 1 present (CI 0.5, RI 0.0).

In the auchenipterids Auchenipterus and Pseudepapterus there is a lateroventral extension of the orbitosphenoid (Royero, 1999: \#42), which is absent in other examined taxa. This character was coded as missing data for auchenipterid Spinipterus.

77. Fenestra between frontal and orbitosphenoid: 0 - absent; 1- present (CI 0.5, RI 0.8).

In the auchenipterids Centromochlinae, Pseudauchenipterus and Pseudotatia there is a fenestra between the frontal and orbitosphenoid (Akama, 1999; Royero, 1999: \#45; Akama, 2004: \#25). That fenestra is absent in other examined taxa. This character was coded as missing data for the auchenipterid Spinipterus.

78. Cranial ventral keel: 0- absent; 1- present (CI 0.2, RI 0.852). Among examined species, the cranial ventral keel is well developed only in the auchenipterids Auchenipterus and Centromochlus, and doradids Anduzedoras, Doras, Hassar, Hemidoras, Nemadoras, Scorpiodoras, Tenellus, Trachydoras, and most basal species of Leptodoras (including L. marki, L. oyakawai, L. praelongus, excluding L. juruensis) (Fig. 33b; Ferraris, 1988: \#N17; Akama, 2004: \#23; Higuchi, 1992: \#40; Sousa, 2010: \#17).

79. Opening(s) for optic and trigeminofacial nerves: 0 - single; 1- separate (CI 1.0, RI 1.0).

In most catfishes the optic and trigeminofacial nerves exit the cranium through separate openings. However, they exit the cranium through the same opening, which is enclosed by the orbitosphenoid, pterosphenoid, prootic and parasphenoid in the Diplomystidae and Nematogenyidae (Alexander, 1965: 95). This character was coded as missing data for the auchenipterid Spinipterus. 

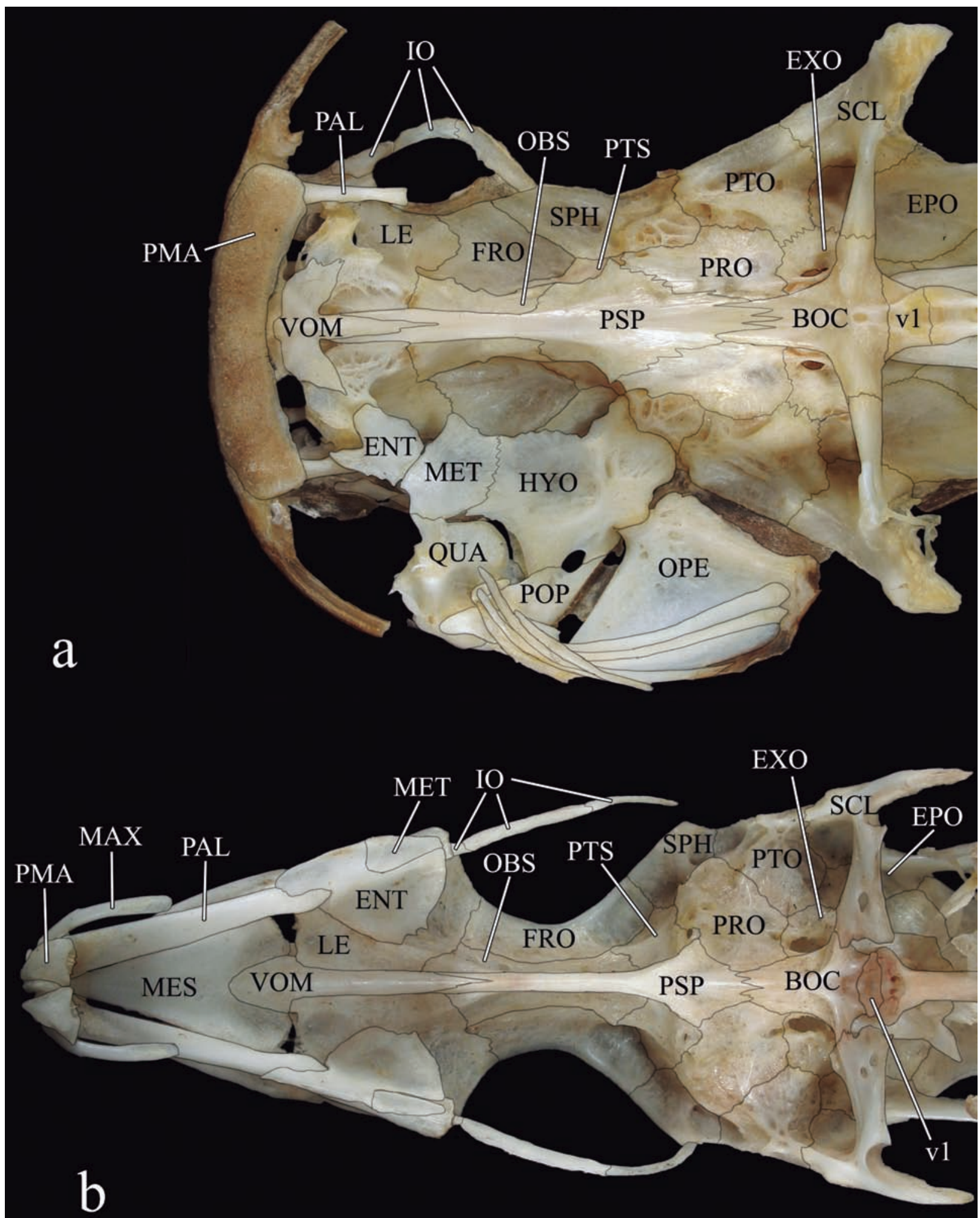

Fig. 33. Head in ventral view of (a) Wertheimeria maculata, MZUSP 93659, 270 mm SL; (b) Doras higuchii, MZUSP 101693, 172 mm SL. BOC basioccipital, ENT entopterygoid, EPO epiotic, EXO exoccipital, FRO frontal, HYO hyomandibula, IO infraorbital, LE lateral ethmoid, OBS orbitosphenoid, MET metapterygoid, OPE opercle, PAL autopalatine, PMA premaxilla, POP preopercle, PRO prootic, PSP parasphenoid, PTS pterosphenoid, QUA quadrate, SCL posttemporal-supracleithrum, SPH sphenotic, v1 vertebra 1 , VOM vomer. 
80. Lateral process of basioccipital: 0 - absent or rudimentary; 1 - present and clearly distinct (CI $0.333, \mathrm{RI} 0.8$ ).

Among examined species, the lateral process of the basioccipital is present and clearly distinct only in members of the Ariidae (except Galeichthys), Aspredinidae, Auchenipteridae, Claroteidae, Doradidae, Erethistidae, Mochokidae, and Sisoridae (Fig. 33; Royero, 1999: \#46; Vigliotta, 2008: \#13; Marceniuk et al., 2012: \#75). This feature was proposed by Lundberg (1993: 180) as support for grouping the undescribed fossil "Titanoglanis" with the Ariidae, Auchenipteridae, Doradidae and Mochokidae. This character was coded as missing data for the auchenipterid Spinipterus.

81. Ventral extension of basioccipital (unordered): 0- absent; 1- present as a ring that ventrally surrounds the aorta; 2present as a lamina ventrally (CI 1.0, RI 1.0).

The ventral face of the basioccipital is flat, without a ventral extension, in most catfishes (Fig. 34a-b). However, the doradid Hassar has the basioccipital extended as a ring that surrounds the aorta ventrally (Fig. 34c; Birindelli et al., 2011), and the doradid Trachydoras has the basioccipital

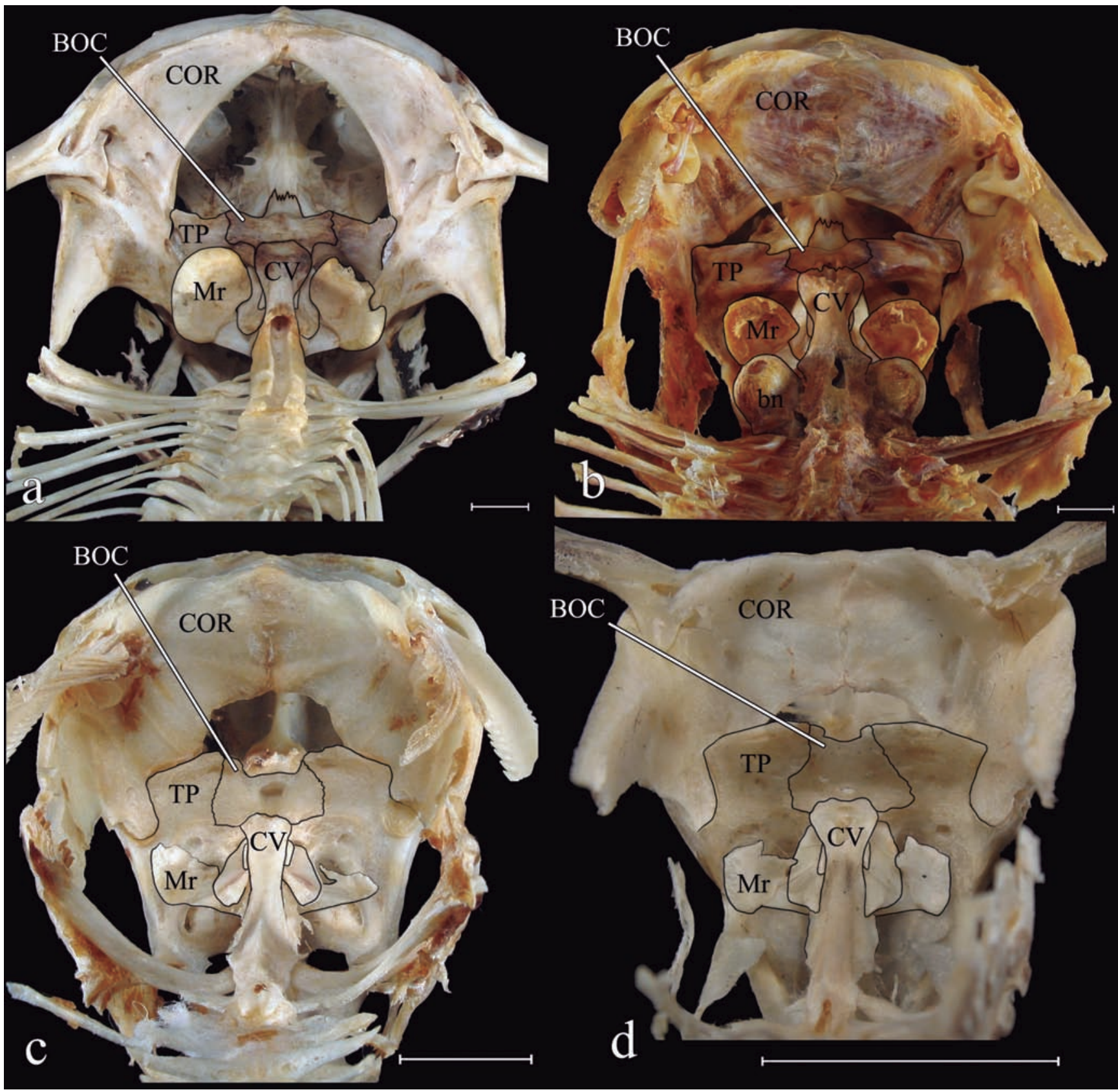

Fig. 34. Pectoral girdle, posterior portion of cranium and anterior vertebra in posteroventral view of (a) Pterodoras rivasi, MZUSP 105825, 350 mm SL; (b) Oxydoras sifontesi, MZUSP 105824, 413 mm SL; (c) Hassar orestis, MZUSP 32542, 220 mm SL; (d) Trachydoras brevis, MZUSP 103087, $74.0 \mathrm{~mm}$ SL. BOC basioccipital, bn bony nodule, COR coracoid, CV complex vertebra, Mr Müllerian ramus, TP transcapular process. Scale bars equal $10 \mathrm{~mm}$. 
ventrally extended as a lamina (Fig. 34d; Higuchi, 1992: \#41). This character was coded as missing data for the auchenipterid Spinipterus.

82. Exoccipital and neural arch of complex vertebra: 0connected by cartilage; 1 - connected by bony suture (CI 1.0, RI 1.0).

In most catfishes, the exoccipital contacts the neural arch of the complex vertebra via cartilage (Fig. 35a; Arratia, 1987). However, in members of the Auchenipteridae and Doradidae, those two bones are sutured together (Fig. 35g; Ferraris, 1988: \#V1; de Pinna, 1993: \#190; Royero, 1999: \#49; Akama, 2004: \#45). This character was coded as missing data for the auchenipterid Spinipterus.

83. Dorsal surface of epiotic: 0- not participating in cephalic shield; 1- participating in cephalic shield (CI 1.0, RI 1.0).

Most catfishes have the dorsal surface of the epiotic below the dorsal surface of the neurocranium and not participating in the cephalic shield (Fig. 20). However, the dorsal face of the epiotic participates in the cephalic shield in the Auchenipteridae and Doradidae (Figs. 21-31; Regan, 1911; Ferraris, 1988: \#N3; de Pinna, 1993: \#77; Royero, 1999: \#29; Britto, 2002: \#48; Diogo, 2004: \#118; Akama, 2004: \#5, \#38; Marceniuk et al., 2012: \#39). Royero (1999: 64) mentioned that the epiotic in the auchenipterid Trachelyopterus galeatus is a composite bone, formed by two ossifications that fuse ontogenetically, one ventral and endochondral (epiotic), and another dorsal and dermal (= parietal of Royero, 1999). The condition described by Royero (1999) was not observed among examined specimens, but if his observations are correct, it is possible that the extrascapular is not absent in the species of Auchenipteridae and Doradidae, but fused to the epiotic, forming the dorsal (dermal) face of a composite bone (see character 88 for other details). Royero (1999: \#15) also mentioned that the epiotic participates in the cephalic shield in the Mochokidae, but that condition was not observed in examined specimens of that family. This character was coded as missing data for the auchenipterid Spinipterus.

84. Posterolateral margin of epiotic: 0- not participating in the border of cephalic shield; 1- participating in border of cephalic shield (CI 0.333, RI 0.929).

The posterolateral margin of the epiotic participates in the lateral border of the cephalic shield in the doradids Anduzedoras, Doras, Hassar, Hemidoras, Leptodoras, Nemadoras, Ossancora, Tenellus and Trachydoras, and Auchenipteridae (except Asterophysus, Liosomadoras, and some specimens of Trachycorystes; Figs. 26-31). This condition is interpreted as resulting from the contact between the posttemporal-supracleithrum and middle nuchal plate, as previously observed by other authors (Higuchi, 1992: \#34; Royero, 1999: \#13; Akama, 2004: \#33). Trachycorystes was coded as polymorphic for this character. This character was coded as inapplicable for all non-Doradoidea taxa, in which the epiotic does not participate in the cephalic shield (see character 83).

85. Posterior process of epiotic (ordered): 0- absent; 1- mainly ligamentous, formed less than half its length by bone; 2- mainly ossified, formed more than half its length by bone (CI 0.133 , RI 0.759).

The epiotic has a posterior process that is ligamentous or eventually ossified in some species. The process is present and mainly ligamentous (i.e., less than half its length formed by bone) in the Mochokidae, Pangasiidae, Schilbeidae, Sisoridae (de Pinna, 1993: \#85; de Pinna, 1996: \#29; Britto, 2002; \#50), ariid Galeichthys (Ariidae; Mo, 1991; Acero \& Betancur, 2007; Marceniuk et al., 2012: \#40), Centromochlinae, auchenipterids Liosomadoras, Tocantinsia, and Trachycorystes, and doradids Acanthodoras, Agamyxis, Centrochir, Centrodoras, Doraops, Franciscodoras, Kalyptodoras, Lithodoras, Megalodoras, Orinocodoras, Oxydoras, Platydoras, Rhinodoras, and Wertheimeria (Chardon, 1968: 229; Britski, 1972: 15; Ferraris, 1988: \#N4; Lundberg, 1993; Royero, 1999: \#50; Akama, 2004: \#7; Sousa, 2010: \#19). The epiotic process is present and mainly ossified (i.e., formed more than half its length by bone) in the Amphiliidae, Ariidae (except Galeichthys), and in the remaining species of Auchenipteridae and Doradidae (Figs. 23, 26, 27, 29-31). This character was coded as missing data for the auchenipterid Spinipterus.

86. Posterior process of epiotic and posterior nuchal plate: 0connected via ligament; 1- sutured (CI 0.5, RI 0.889).

In all Amphiliidae, Ariidae, Auchenipteridae, Mochokidae, Pangasiidae, and most members of Doradidae, the posterior process of the epiotic is connected via ligament either to the posterior nuchal plate or to the infranuchal ligament (Figs. 26-27). However, the posterior process of the epiotic is connected via bony suture to the posterior nuchal plate in the doradids Anduzedoras, Doras carinatus, D. higuchii, D. micropoeus, Hassar and Leptodoras (Higuchi, 1992: \#37, \#38; Birindelli et al., 2011). This character was coded as inapplicable for the Aspredinidae, Claroteidae, Diplomystidae, Erethistidae, Heptapteridae, Ictaluridae, Malapteruridae,

Fig. 35 (next page). Anterior vertebrae in lateral (left) and ventral (right) views of (a,b) Ictalurus punctatus, MZUSP 103245, 155 mm SL; (c,d) Genidens genidens, MZUSP 5693, 250 mm SL; (e,f) Synodontis schall, ANSP 78057, unmeasured; (g,h) Wertheimeria maculata, MZUSP 93658, 220 mm SL. ANP anterior nuchal plate, BOC basioccipital, CV complex vertebra, EPO epiotic, EXO exoccipital, INS infranuchal scute, MNP middle nuchal plate, NScv neural spine of complex vertebra, pEPO epiotic process, PNP posterior nuchal plate, Pv4 parapophysis of fourth vertebra, Pv5 parapophysis of fifth vertebra, OS os suspensorium, SCL posttemporal-supracleithrum, SOC parietal-supraoccipital, TP transcapular process, TRI tripus, v6-8 vertebrae 6-8. Scale bars equal $10 \mathrm{~mm}$. 


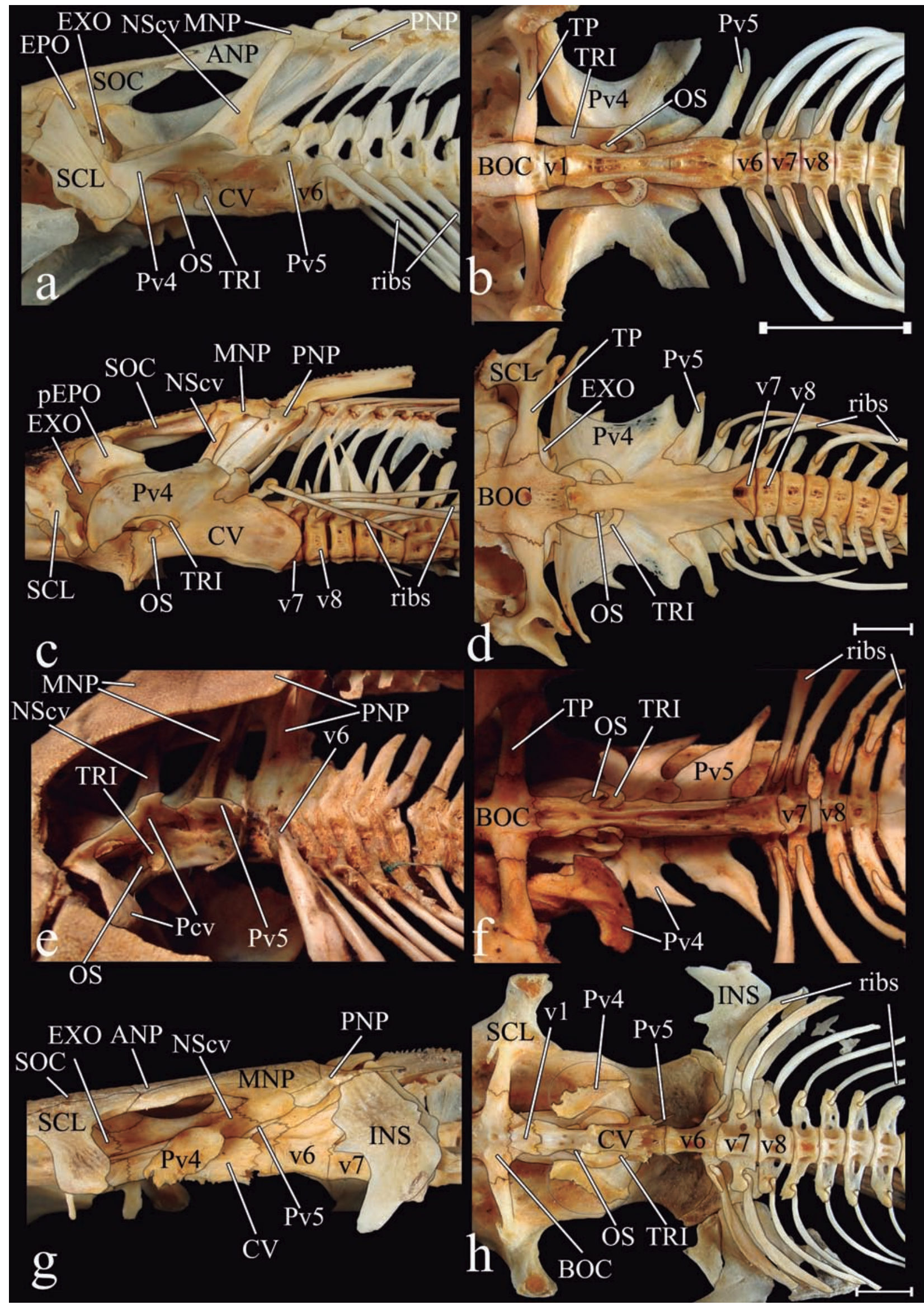


Nematogenyidae, Pimelodidae, Pseudopimelodidae, and Siluridae, which lack an epiotic process; and as missing data for the auchenipterid Spinipterus.

87. Posterior process of epiotic and parapophyses of fifth and sixth vertebrae: 0 - not sutured; 1 - sutured (CI 0.25, RI $0.571)$.

In the Amphiliidae, Ariidae, Doradidae, Mochokidae, Pangasiidae, Schilbeidae Sisoridae, and most species of Auchenipteridae, the posterior process of the epiotic is not connected to the parapophyses of the fifth and sixth vertebrae (Figs. 21-29). However, it is sutured to the parapophyses of the fifth and sixth vertebrae in the auchenipterids Ageneiosus, Auchenipterus, Epapterus, Pseudepapterus, Trachelyichthys, Trachelyopterus coriaceus, and Tetranematichthys (Figs. 30, 31; Ferraris, 1988: \#N5, \#N7, \#V10; Curran, 1989: \#3; Walsh, 1990: \#19; Royero, 1999: \#51, \#52, \#53,\#54; Akama, 2004: \#8, \#9,\#10,\#11). Britski (1972: 17) suggested that the development of the epiotic process is inversely proportional to the development of the nuchal shield, functioning to strengthen the connection between the cranium and the dorsal fin in catfishes with relatively less developed nuchal shields. This character was coded as inapplicable for the Aspredinidae, Claroteidae, Diplomystidae, Erethistidae, Heptapteridae, Ictaluridae, Malapteruridae, Nematogenyidae, Pangasiidae, Pimelodidae, Pseudopimelodidae, and Siluridae, which lack an epiotic process; and as missing data for the auchenipterid Spinipterus.

88. Extrascapular: 0- present; 1- absent (CI 0.2, RI 0.6).

The extrascapular is absent in the Aspredinidae, Auchenipteridae, Amphiliidae, Doradidae, Erethistidae, Mochokidae, Nematogenyidae, and Siluridae (Figs. 21-31; Lundberg, 1970: \#24; Arratia, 1992: \#43; Britto, 2002: \#51; Vigliotta, 2008:\#14). Royero (1999) mentioned that one dermal ossification center ontogenetically fuses to the epiotic in Trachelyopterus galeatus. The extrascapular of most catfishes occupies a similar position of the dermal portion of the epiotic in the Doradoidea. The similar position, the absence of a distinct extrascapular in adults, and the presence of an extra dermal ossification center ontogenetically fused to the epiotic in at least some members of the Doradoidea, suggest that the extrascapular might be present and fused to the epiotic in these taxa, and not entirely lost as in other catfishes. However, in the absence of further evidence (e.g., ontogenetic series of development indicating the ontogenetic fusion between extrascapular and epiotic in some specimens), the extrascapular in the Auchenipteridae and Doradidae is herein treated as absent. This character was coded as missing data for the auchenipterid Spinipterus.

89. Connection between cranium and posttemporalsupracleithrum: 0 - through ligaments; 1 - through bony suture (CI 0.25, RI 0.727).

The posttemporal-supracleithrum is sutured to the cranium in members of the Akysidae, Amphiliidae, Astroblepidae, Auchenipteridae, Callichthyidae, Clariidae, Doradidae, Erethistidae, Loricariidae, Mochokidae, Nematogenyidae, Scoloplacidae, and Sisoridae (Figs. 21-31; Alexander, 1965: 119; Chardon, 1968: 229; de Pinna, 1993: \#26; Royero, 1999:\#16; Britto, 2002: \#38; Arratia, 2003a: 130; Diogo, 2004: \#155; Vigliotta, 2008: \#15). In other examined taxa, those structures are loosely connected by ligaments (Fig. 20).

90. Posttemporal-supracleithrum and parapophysis of fourth vertebra: 0 - not connected at all; 1 - connected by bony suture (CI1.0, RI 1.0).

Among examined taxa, the posttemporal-supracleithrum is sutured to the parapophysis of the fourth vertebra only in the Aspredinidae, Erethistidae and Sisoridae (de Pinna, 1996: \#27; Britto, 2002; \#44). This character was coded as missing data for the auchenipterid Spinipterus.

91. Posttemporal fossa: 0- absent; 1- present (CI 1.0, RI 1.0). In members of the Aspredinidae, Erethistidae and Sisoridae there is a groove between the parietal-supraoccipital, pterotic and posttemporal-supracleithrum (de Pinna, 1996: \#24; Britto, 2002: \#55; Diogo, 2004:\#123). That groove is interpreted as the posttemporal fossa, and is absent in all other examined taxa. This character was coded as missing data for the auchenipterid Spinipterus.

92. Direction of transcapular process: 0- approximately transverse to body axis; 1 - at an angle of approximately $45^{\circ}$ relative to body axis (CI 0.5, RI 0.8).

The transcapular process is at an angle of approximately $45^{\circ}$ relative to the body axis in the auchenipterids Ageneiosus, Auchenipterus, Epapterus, Pseudepapterus, and Tetranematichthys (Fig. 36a; Royero, 1999: \#47; Akama, 2004: \#44). In all other examined taxa, that process is approximately transverse to the body axis (Fig. 36b-d). This character was coded as missing data for the auchenipterid Spinipterus.

93. Shape of transcapular process: 0 - blunt, not extended ventrally; 1- ventrally extended into bony lamina (CI 1.0, RI 1.0)

In the doradids Anduzedoras, Doras, Hassar, Hemidoras, Leptodoras, Nemadoras, Ossancora, Oxydoras, Tenellus, and Trachydoras, the transcapular process is ventrally extended into a bony lamina, associated with the dorsally extended coracoid, serving as a bony diaphragm (Figs. 34b-d; Eigenmann, 1925: 287; Higuchi, 1992: \#29, \#30, \#41). The transcapular process is blunt, not extended ventrally in all other examined species (Fig. 34a).

\section{Laterosensory canals.}

94. Shape of nasal: 0- tubular; 1- plate-like, dorsally expanded (CI 0.2, RI 0.2).

The nasal of catfishes is usually a tubular bone associated to the supraorbital canal, with a lateral branch that is variably ossified (Figs. 20-21, 25-27, 30-31). However, in the examined 
species of doradids Kalyptodoras and Platydoras (except Platydoras sp.), and auchenipterids Tatia, Trachelyopterus galeatus, Trachelyopterichthys, and Trachycorystes, the nasal is plate-like, dorsally expanded (Figs. 22, 29; SoaresPorto, 1998: \#5; Akama, 2004: \#91, \#93; Sousa, 2010: \#20). This character is coded as missing data for Spinipterus acsi.

95. Contact between infraorbital 1 and lateral ethmoid: 0- weak; 1- strong (CI 0.2, RI 1.0).

In members of the Auchenipteridae and Doradidae the first infraorbital is firmly attached to the lateral ethmoid by strong ligaments or, in some species, by a bony suture (Figs.
21-31; Britski, 1972: 13; Mo, 1991: \#55; de Pinna, 1993: \#113; Royero, 1999:\#8,\#106; Britto, 2002: \#65; Akama, 2004:\#29). In other catfishes the first infraorbital is only weakly attached to the lateral ethmoid via ligaments (Fig. 20).

96. Length of contact between infraorbital 1 and lateral ethmoid: 0 - short or absent, occupying most of medial margin of infraorbital 1; 1- long, extended over most of medial margin of infraorbital 1 (CI 1.0, RI 1.0).

In the auchenipterids Auchenipterus, Epapterus, and Pseudepapterus, the suture between infraorbital 1 and the lateral ethmoid is elongate, extended over most of medial margin

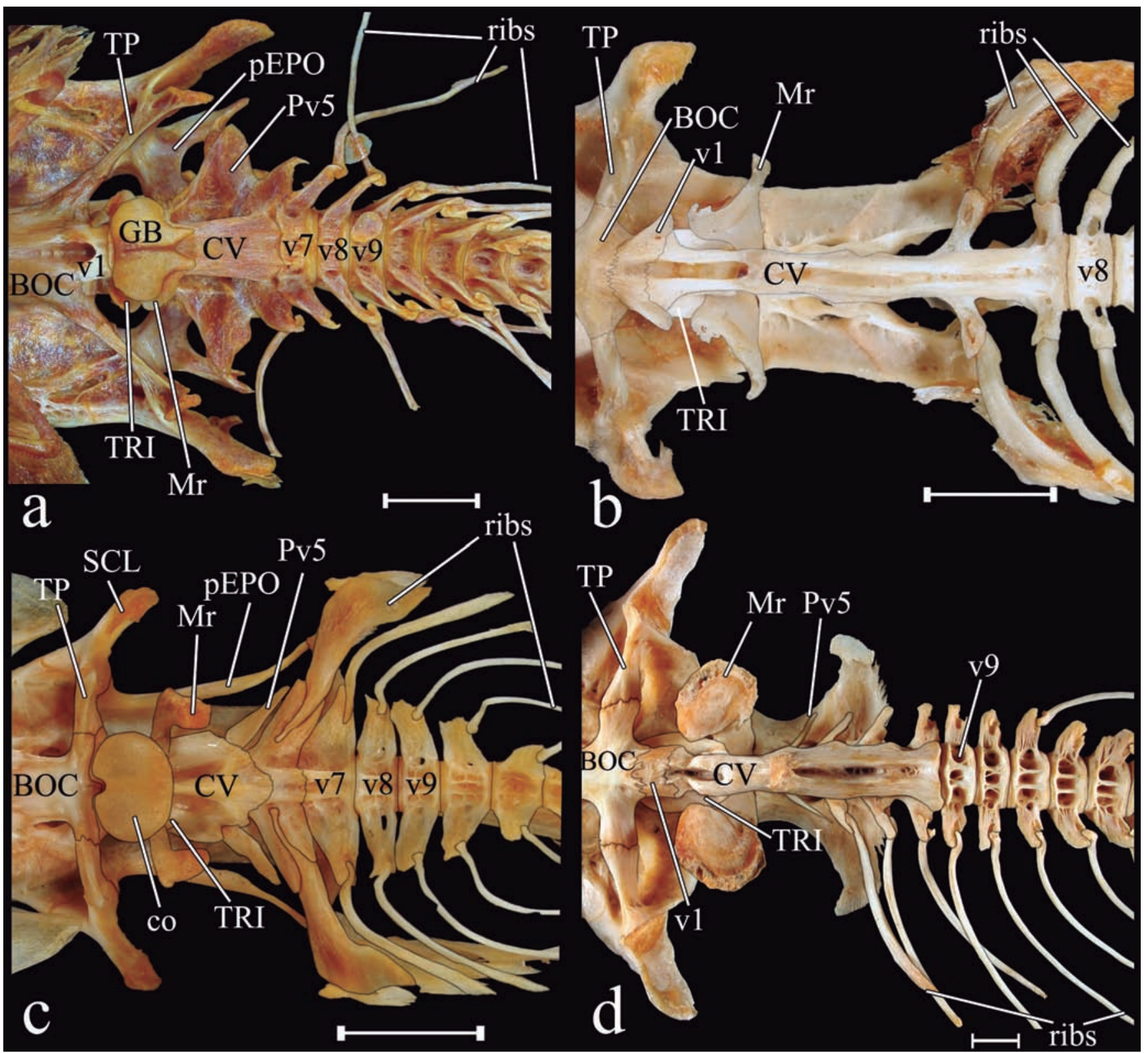

Fig. 36. Anterior vertebrae in ventral view of (a) Ageneiosus inermis, MZUSP 91661, 320 mm SL; (b) Rhinodoras dorbignyi, MZUSP 40109, 196 mm SL; (c) Leptodoras juruensis, MZUSP 104532, 227 mm SL; (d) Tocantinsia piresi, MZUSP 100031, 430 mm SL. bc bony capsule, BOC basioccipital, CV complex vertebra, GB gas bladder, Pv5 parapophysis of fifth vertebra, Mr Müllerian ramus, TP transcapular process, TRI tripus, v1-8 vertebrae 1-8. Scale bars equal $10 \mathrm{~mm}$. 
of infraorbital 1 (Fig. 30; Ferraris, 1988: \#I9; Royero, 1999: \#8; Akama, 2004: \#96); whereas in other catfishes this contact is relatively short, or eventually absent in some specimens (Figs. 20-29, 31).

97. Infraorbital 1 in orbital margin: 0- not participating; 1 participating (CI 0.333, RI 0.933).

In the Auchenipteridae, Astrodoradinae and doradids Acanthodoras, Agamyxis, Lithodoras, and Pterodoras, the infraorbital 1 participates in the orbital margin (Figs. 23, 2830; Higuchi, 1992: \#A13; Sousa, 2010: \#22), whereas it is located distinctly anterior to the orbital margin in other examined taxa (Figs. 20-22, 24-27).

98. Ventral process of infraorbital 1: 0- absent; 1 - present (CI 0.5, RI 0.857).

In the examined species of the auchenipterids Ageneiosus, Auchenipterus, Centromochlus, Entomocorus, Epapterus, Pseudepapterus, and Tetranematichthys, the infraorbital 1 has a well-developed ventral process (Figs. 30, 31; Ferraris, 1988: \#I2, Walsh, 1990: \#13; Soares-Porto, 1998: \#14; Akama, 2004; \#29), which is absent in other examined taxa (Figs. 2029). This character was coded as missing data for the auchenipterid Spinipterus.

99. Serrated crest on infraorbital 1: 0- absent; 1- present (CI 0.25, RI 0.667).

In the doradids Acanthodoras, Agamyxis, Astrodoras, Centrochir, Centrodoras, Megalodoras, Platydoras, Scorpiodoras and some specimens of Anadoras (especially small ones), infraorbital 1 has a serrated transverse crest (Eigenmann, 1925: 286; Higuchi, 1992: \#20, \#21; Higuchi et al., 2007; Sousa, 2010: \#23). Anadoras was coded as polymorphic for this character. All other examined species lack a serrated crest on infraorbital 1.

100. Length of anterior portion of infraorbital 1: 0- relatively small, smaller than length of posterior portion; 1- relatively large, similar in size to posterior portion (CI 0.5, RI 0.889).

In most catfishes, infraorbital 1 is shaped as a sickle with the anterior portion anteriorly acute and notably smaller than its posterior portion (Fig. 37a; Lundberg, 1970: fig. 55; Arratia, 1987: fig. 13; Sabaj Pérez \& Birindelli, 2008: fig. 4A). However, in the doradids Anduzedoras, Doras carinatus, D. higuchii, D. micropoeus, Hassar, and Leptodoras, the infraorbital 1 has an expanded anterior portion, which is similar in size to the posterior portion (Fig. 37b; Sabaj Pérez \& Birindelli, 2008).

101. Mesethmoid and infraorbital 1: 0 - connected via ligaments, not sutured; 1- connected via bony suture (CI 1.0, RI 1.0).

The doradid Trachydoras has the infraorbital 1 ventrally sutured to the mesethmoid, forming a bony floor for the nasal capsule (Fig. 26; Higuchi, 1992: \#A29), whereas it is connected via ligaments in other examined taxa (Figs. 20-25, 27-31). This

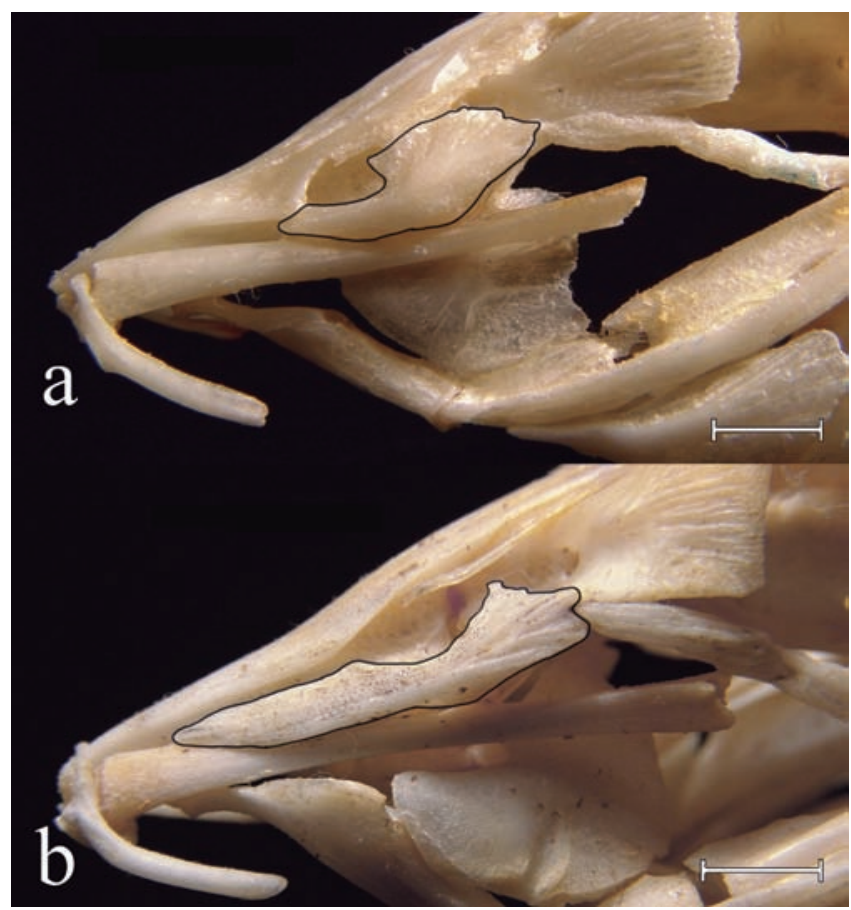

Fig. 37. Snout in lateral view of (a) Doras phlyzakion, MZUSP 82294, 165 mm SL; (b) Doras higuchii, MZUSP 96334, 185 mm SL. Infraorbitals outlined. Scale bars equal $10 \mathrm{~mm}$.

character was coded as missing data for the auchenipterid Spinipterus.

102. Number of infraorbitals (ordered): 0 - seven or more; 1 six; 2- five; 3- four (CI 0.273-0.3, RI 0.529-0.588).

Among other examined catfishes, the Diplomystidae, Ictaluridae and Nematogenyidae have seven or more infraorbitals (Lundberg, 1970: \#28; Arratia, 1987; Arratia \& Huaquin, 1995); Pangasiidae and Sisoridae have six; Amphiliidae, Claroteidae, Heptapteridae, Malapteruridae, and Siluridae have five; and Ariidae, Aspredinidae, Erethistidae, Pimelodidae, and Pseudopimelodidae have four (Kulongowski, 2001; Marceniuk et al., 2012: \#88). All mochokids have four infraorbitals, except Synodontis zambezensis and the Chiloglanidinae with five (Vigliotta, 2008: \#23). All species of Doradidae have four infraorbitals, except Anadoras with five (Sousa, 2010: \#21) and some specimens of Oxydoras (latter coded as polymorphic: 2,3) also with five. In the Auchenipteridae, most species have the tubules of the infraorbital series variably ossified, with a variable number of ossifications between two adjacent pores. Therefore, the number of ossified infraorbitals is highly variable in auchenipterids (even within a single species) (Ferraris, 1988: \#I1; Akama, 2004: \#89). In order to establish the homology between the infraorbitals of auchenipterids and other catfishes, the number of infraorbitals for species of the former is herein considered as the number of tubules (independent of its ossification) between two pores. In this sense, all species of Auchenipteridae have four infraorbitals, except some specimens of Glanidium (coded as polymorphic: 2,3). This 
character was coded as missing data for the auchenipterids Pseudotatia and Spinipterus.

103. Shape of posteriormost infraorbital: 0- tubular; 1 - platelike (CI 0.167, RI 0.375).

The infraorbitals are numbered from anterior to posteriormost. However, their homology can also be determined by their position, relative to the cranium. Therefore, the infraorbital 4 of most auchenipterids and doradids is considered homologous to infraorbital 7 of Diplomystidae, because both are the posteriormost and in contact with the sphenoid. The posteriormost infraorbital (= infraorbital 4 in most auchenipterids and doradids) is plate-like in the doradids Acanthodoras, Agamyxis, Kalyptodoras, Lithodoras, Orinocodoras, Platydoras (except Platydoras sp.), Pterodoras, and auchenipterid Trachycorystes (Figs. 22-24, 29; Ferraris, 1988: \#I8; Akama, 2004: \#95), whereas in other examined taxa the posteriormost infraorbital is tubular (Figs. 20-21, 26-27, 31).

104. Shape of penultimate infraorbital: 0 - tubular; plate-like (CI 0.2, RI 0.5).

The second posteriormost infraorbital (= infraorbital 3 of most auchenipterids and doradids) is plate-like in doradids Acanthodoras, Agamyxis, Kalyptodoras, Lithodoras, Megalodoras, Platydoras (except Platydoras sp.), and Pterodoras (Figs. 22, 23; Higuchi, 1992: \#26, \#27), whereas in other examined taxa the structure is tubular (Figs. 20-21, 24, 26-27, 31).

105. Shape of infraorbital 2: 0- tubular; 1 - plate-like (CI 0.333, RI 0.333).

The infraorbital 2 is plate-like in Acanthodoras, Agamyxis, Kalyptodoras, and Platydoras (except Platydoras sp.) (Fig. 22; Higuchi, 1992: \#25), whereas it is tubular in all other examined taxa (Figs. 20-21, 23-24, 26-27, 31).

106. Spines on infraorbitals: 0 - absent; 1 - present (CI 0.125 , RI 0.462).

The infraorbitals have small spines in the doradids Acanthodoras, Agamyxis, Astrodoras, Hemidoras morei, $\mathrm{H}$. morrisi, H. stenopeltis, Platydoras, Scorpiodoras and Trachydoras steindachneri, and auchenipterids Liosomadoras, Trachelyopterichthys, Trachycorystes, and Spinipterus (Figs. 22, 29; Britski, 1972: 13; Royero, 1999:\#102; Akama, 2004: \#100; Sousa, 2010: \#25); this condition is absent in other examined taxa (Figs. 20-21, 23-24, 26-27, 31).

107. Location of exit of infraorbital canal from cranium: 0 - on the anterior portion of sphenotic; 1- on the posterior portion of sphenotic (CI 0.5, RI 0.969).

In the doradids Anduzedoras, Doras, Hassar, Hemidoras, Leptodoras, Nemadoras, Ossancora, Oxydoras, Tenellus, and Trachydoras the infraorbitals are connected to the posterior portion of the sphenotic (Figs. 25-27; Higuchi, 1992: \#24). The same condition occurs in the mochokids of the genus Synodontis, which also have deep head and large eye. In all other examined species, the infraorbitals are connected to the anterior portion of sphenotic (Figs. 20-24). This character was coded as missing data for the auchenipterid Spinipterus.

108. Temporal canal: 0 - passing from pterotic to posttemporalsupracleithrum; 1- passing from pterotic, through epiotic, to posttemporal-supracleithrum (CI 1.0, RI 1.0).

In most catfishes the temporal canal passes from the pterotic, through the epiotic, to the posttemporalsupracleithrum. However, in the auchenipterids Auchenipterus, Entomocorus, Epapterus, and Pseudepapterus the temporal canal passes from the pterotic, through the epiotic, to the posttemporal-surpacleithrum (Royero, 1999: \#94; Akama, 2004: \#104). This character was coded as missing data for the auchenipterid Spinipterus.

109. Pterotic ramus of temporal canal: 0 - present; 1 - absent (CI 1.0, RI 1.0).

In the auchenipterids Auchenipterus, Entomocorus, Epapterus, and Pseudepapterus the pterotic ramus of the temporal canal is absent (Royero, 1999: \#96); in all other examined taxa, the pterotic ramus of the temporal canal is present. This character was coded as missing data for the auchenipterid Spinipterus.

110. Accessory pore of otic canal: 0 - absent; 1 - present (CI 1.0, RI 1.0).

Among examined species, there is an accessory pore on the otic canal near the lateral border of the cephalic shield only in the auchenipterids Auchenipterus, Entomocorus, Epapterus, and Pseudepapterus (Royero, 1999: \#97; Akama, 2004: \#102). This character was coded as missing data for the auchenipterid Spinipterus.

111. Mandibular canal: 0- present; 1 - absent (CI 0.5, RI 0.667).

The mandibular canal is absent in the sisorid Sisor, erethistid Conta, Aspredinidae, and mochokids Chiloglanidinae (de Pinna, 1996: \#3; Britto, 2002: \#67). The mandibular canal is present in other examined taxa. This character was coded as missing data for the auchenipterid Spinipterus.

112. Mandibular canal: 0 - passing inside lower jaw; 1 - passing outside lower jaw (CI and RI inapplicable).

The mandibular canal passes outside of the anguloarticular and dentary in the auchenipterid Gelanoglanis (Ferraris, 1988: \#I10; Rengifo et al., 2008). This character was coded as inapplicable for the Aspredinidae, Erethistidae and mochokid Chiloglanis, which lack the mandibular canal; and as missing data for the auchenipterid Spinipterus.

113. Number of pores on mandibular canal (ordered): 0 - three or less; 1 - four; 2- five or six; 3- seven or more (CI 0.176, RI 0.839 ). 
In most catfishes, there are five or six pores along the mandibular canal (Lundberg, 1970: \#42); the presence of five or six pores varing among and within the species. Most species of Auchenipteridae and Doradidae have five or six pores on the mandibular canal. However, the doradids Acanthodoras, Agamyxis, Centrodoras, Megalodoras, and Oxydoras have only four pores, and members of the Anduzedoras, Doras, Hassar, Hemidoras, Leptodoras, Nemadoras, Ossancora, Tenellus, and Trachydoras have only three pores. On the other hand, the auchenipterids Trachelyopterus have seven, and Asterophysus, Trachelyopterichthys, and Trachycorystes have eight pores. All mochokids have two or three pores (Vigliotta, 2008: \#87), whereas species of Ariidae, Claroteidae, Pimelodidae, Pseudopimelodidae, and Siluridae have eight pores, Malapteruridae have seven and Amphiliidae have three. This character was coded as missing data for auchenipterids Tocantinsia, Pseudotatia, Spinipterus, and doradids Doraops and Rhynchodoras; and as inapplicable for Aspredinidae, Erethistidae, Sisoridae, and mochokid Chiloglanis, which lack the mandibular canal.

114. Number of pores of each exit of sensory canals: 0- one; 1- numerous (CI 0.333, RI 0.333).

Most catfishes have a single opening for each exit of the sensory canals. However, each exit of the sensory canals is branched into smaller canals with multiple pores near the skin in the Ariidae, Pangasiidae, Pimelodidae, and Plotosidae (Lundberg, 1970; Arratia, 1992: \#64; de Pinna, 1993: \#109; Arratia \& Huaquin, 1995: \#1; Royero, 1999: \#98; Vigliotta, 2008:\#86).

115. Lateral line shape: 0 - straight; 1 - sinusoidal (CI 0.333, RI $0.889)$.

The lateral line is sinusoidal in all species of the Auchenipteridae (Figs. 38b-d; Ferraris, 1988: \#I12; Akama, 2004: \#97), except for the examined species of Gelanoglanis, Glanidium, Tatia, and Spinipterus (Fig. 38a). Ferraris (1988: \#I12) mentioned that this feature is present in the auchenipterids Centromochlus, Glanidium, and Tatia, and Akama (2004: \#97) in Glanidium and Tatia, but the only specimens of Centromochlinae examined herein with sinusoidal lateral line are those of Centromochlus heckelii (Fig. 38b). The lateral line is straight in other examined taxa.

116. Posterior terminus of lateral line: 0 - unbranched; 1 branched into two divergent rami (CI 0.333, RI 0.778).

Most species of catfishes have the posterior terminus of the lateral line unbranched. In the auchenipterids Ageneiosus, Asterophysus, Auchenipterus, Epapterus, Pseudepapterus, Tetranematichthys, Trachelyopterus, and Trachycorystes, the terminus of the lateral line on the caudal-fin base is posteriorly branched into two divergent rami (Britski, 1972; Ferraris, 1988: \#I11; Royero, 1999: \#101, Akama, 2004: \#88). In some of those taxa, including Auchenipterus nuchalis and Trachelyopterus, the posterior rami are parallel or weakly divergent, but in others, such as Auchenipterus ambyacus and Asterophysus, they are widely divergent, each approximately vertical (Akama, 2004: \#88). This character was coded as missing data for Pseudotatia, and as inapplicable for Entomocorus, because the lateral line terminates anterior to the caudal-fin base.

117. Vertical rows of neuromasts dorsal to lateral line: 0 - absent; 1- present (CI 0.333, RI 0.846).

All auchenipterids (except Ageneiosus, Auchenipterus, Entomocorus, Epapterus, Gelanoglanis, Pseudepapterus, Spinipterus and Tetranematichthys) have vertical rows of neuromasts dorsal to the lateral line (Fig. 38d; Ferraris, 1988: \#I13); a condition absent in all other examined species.

118. Midlateral scutes (ordered): 0 - absent; 1 - present, but not well developed along the entire body; 2- present and well developed along the entire body (CI 0.333, RI 0.956).

The lateral-line tubules are developed as a longitudinal row of midlateral bony scutes in all species of Doradidae (Eigenmann, 1925; Ferraris, 1988: \#I15; Higuchi, 1992: \#87; Royero, 1999:\#103,\#105; Akama, 2004: \#99). This is the most conspicuous feature shared among doradids and was recognized by the earliest studies about these fishes (e.g., Linnaeus, 1766). In the doradids Doras micropoeus, Doraops, Hassar, Kalyptodoras, Nemadoras hemipeltis, Tenellus leporhinus, and Wertheimeria, however, the midlateral scutes are weakly developed (Eigenmann, 1925: 301; Higuchi, 1992: \#96; Sousa, 2010: \#28; Birindelli et al., 2011). Midlateral scutes are absent in all other examined species. This character was ordered according to the ontogenetic series of development.

119. Retrorse thorn on midlateral scutes: 0 - absent; 1 - present (CI and RI inapplicable).

In most doradids, each midlateral scute has a retrorse thorn (Figs. 39b-f). In Wertheimeria, however, the midlateral scutes are usually smooth (without spines) and covered by thick skin (Fig. 39a). Retrorse thorns are present only in the midlateral scutes of the caudal peduncle in specimens up to $75 \mathrm{~mm}$ SL of Wertheimeria. This character was coded as inapplicable for all non-Doradidae taxa, which lack midlateral scutes.

120. Orientation of midlateral scutes: approximately perpendicular to long axis of body; 1- oblique to long axis of body (CI 1.0, RI 1.0).

In the doradids Anduzedoras, Doras, Hassar, Hemidoras, Leptodoras, Nemadoras, Ossancora, Tenellus, and Trachydoras, the midlateral scutes are oblique, at an approximately $60^{\circ}$ angle relative to the longitudinal axis of the body, with the dorsal wing anterior to the ventral wing (Fig. 39f). This character was coded as inapplicable for all nonDoradidae taxa, which lack midlateral scutes.

121. Depth of midlateral scutes: 0 - generally one-fifth to onehalf of body depth at anal-fin origin; 1- generally more than half of body depth at anal-fin origin (CI 0.5, RI 0.667). 

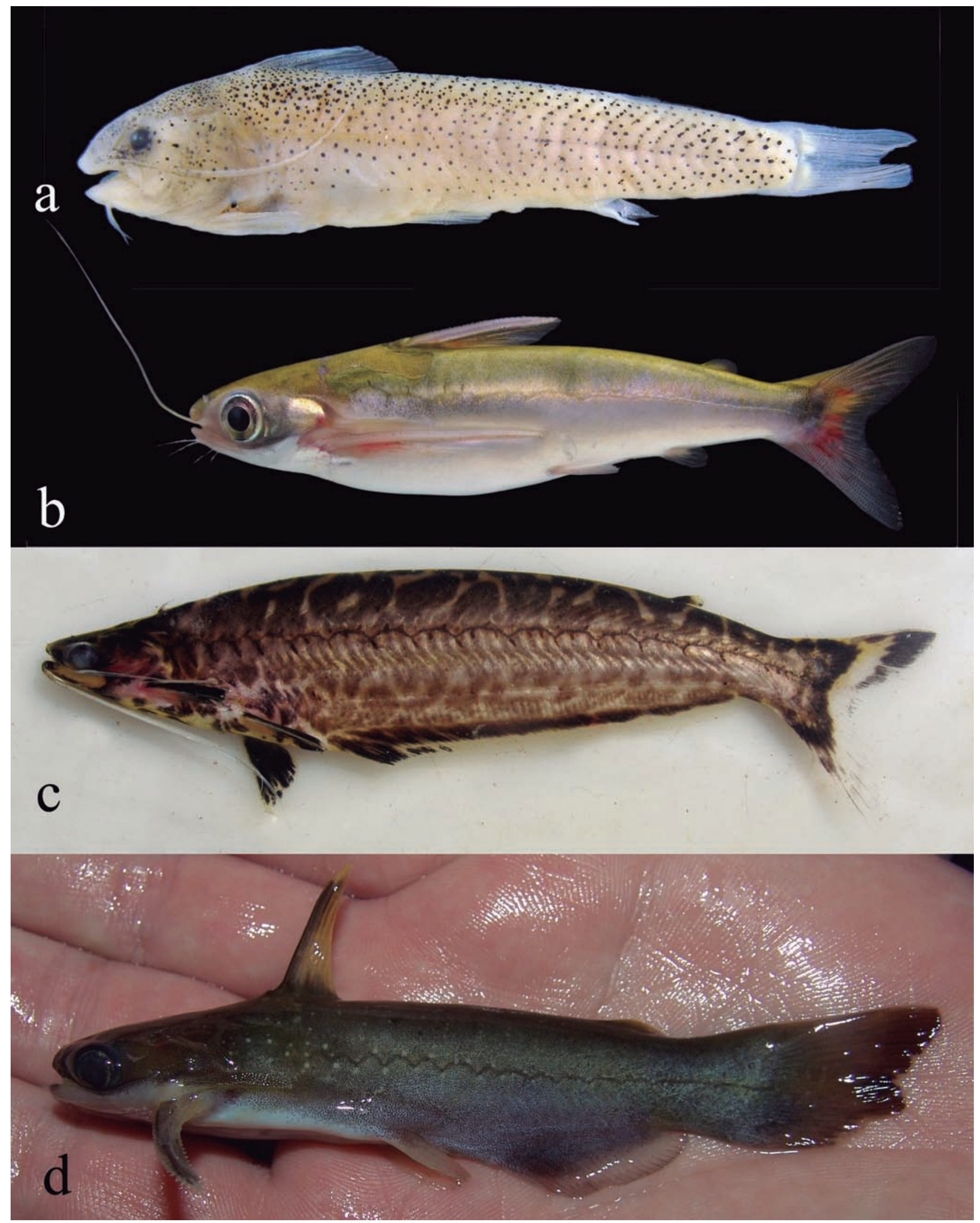

Fig. 38. Gelanoglanis cf. stroudi (a), MZUSP 96032, $26.2 \mathrm{~mm}$ SL, rio Teles Pires, Itaituba, Mato Grosso; (b) Centromochlus heckelii, MZUSP 104793, approximately 100 mm SL, rio Jari, Monte Dourado, Pará, photographed live; (c) Pseudepapterus hasemani, MZUSP 104772, 115.2 mm SL, rio Jari, Monte Dourado, Pará, photographed live; (d) Auchenipterichthys longimanus, INPA uncatalogued, approximately 80 mm SL, rio Tapajós, Itaituba, Pará, photographed live. 


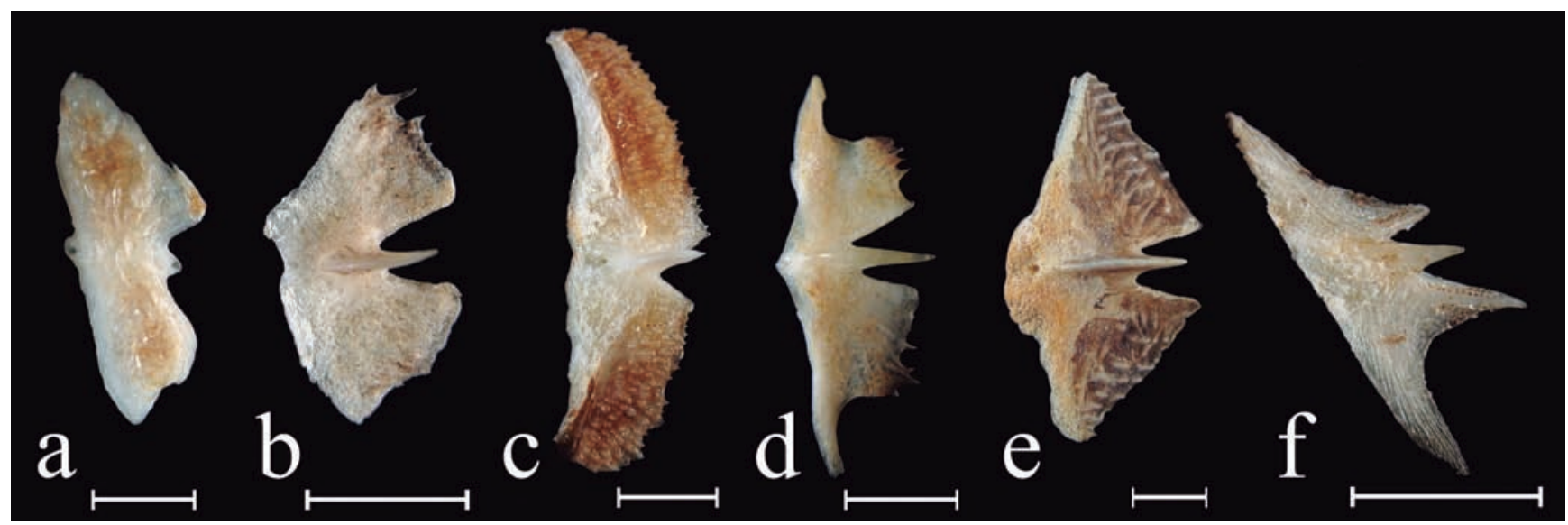

Fig. 39. Midlateral scutes of the anterior portion of body in lateral view (original orientation preserved) of (a) Wertheimeria maculata, MZUSP 93659, 192 mm SL; (b) Centrochir crocodili, MZUSP 15087, 150.8 mm SL; (c) Platydoras armatulus, MZUSP 91686, 151.7 mm SL; (d) Orinocodoras eigenmanni, FMNH 105276, 193 mm SL; (e) Oxydoras niger, MZUSP 91858,313 mm SL; (f) Doras phlyzakion, MZUSP 82294, 162 mm SL. Scale bars equals 5 mm.

In doradids Acanthodoras, Agamyxis, Astrodoras, Platydoras armatulus, $P$. brachylecis, $P$. hancockii (among examined species), the midlateral scutes are deep, with depth more than half of body depth at anal-fin origin (Fig. 39c; Higuchi, 1992: A64; Sabaj, 2002: \#22; Sousa, 2010: \#29). In other doradids the midlateral scutes are shallower (Fig. 39ab,d-f). This character was coded as inapplicable for all nondoradid taxa, which lack midlateral scutes.

122. Size of third tympanal scute: 0 - distinctly smaller than postinfranuchal scutes; 1 - similar in size to anterior postinfranuchal scutes (CI 0.5, RI 0.95).

In the doradids Acanthodoras, Agamyxis, Anadoras, Centrodoras, Doraops, Franciscodoras, Kalyptodoras, Lithodoras, Megalodoras, Platydoras, Pterodoras, Orinocodoras, Rhinodoras, Scorpiodoras, Wertheimeria, and some specimens of Centrochir, the third tympanal scute is relatively large, similar in size to anterior postinfranuchal scutes (Figs. 21, 22, 24; Sousa, 2010: \#26). The doradids Centrochir and Rhinodoras dorbignyi were coded as polymorphic for this character, for having specimens with the third infranuchal scute relatively small and others with the scute relatively large. This character was coded as inapplicable for all non-Doradidae taxa, which lack midlateral scutes.

123. Number of midlateral scutes (ordered): 0 - 15 to 25 ; 1 - 26 to 38 ; $2-39$ to 46 (CI 0.5, RI 0.778).

The number of midlateral scutes in doradids was conventionally established as beginning with the infranuchal scute, and is useful in species diagnosis (Sabaj, 2005; Birindelli et al., 2007). The number of midlateral scutes may vary significantly among species of a single genus (e.g., Oxydoras), but it is quite conservative within a single species. Although the variation in the number of midlateral scutes is continuous among species of Doradidae, there are two groups of species that are distinctly different from others based on the number of scutes, the first group having 15 to 25 midlateral scutes, and the second having 39 to 46 . Fifteen to 25 midlateral scutes are present in Acanthodoras spinosissimus, Agamyxis pectinifrons, Centrodoras hasemani, Doraops, Lithodoras, Megalodoras, and Pterodoras. On the other hand, Anduzedoras and distal species of Leptodoras (excluding $L$. copei, L. marki, L. oyakawai, L. praelongus, and some specimens of $L$. hasemani) have 39 midlateral scutes or more (Sabaj, 2002: \#21). This character was coded as inapplicable for all non-Doradidae taxa, which lack midlateral scutes.

\section{Jaws.}

124. Shape of mandibular arch: 0 - approximately straight in lateral view; 1- distinctly curved ventrally (CI 1.0, RI 1.0).

In the doradid Rhynchodoras both jaws have a concave

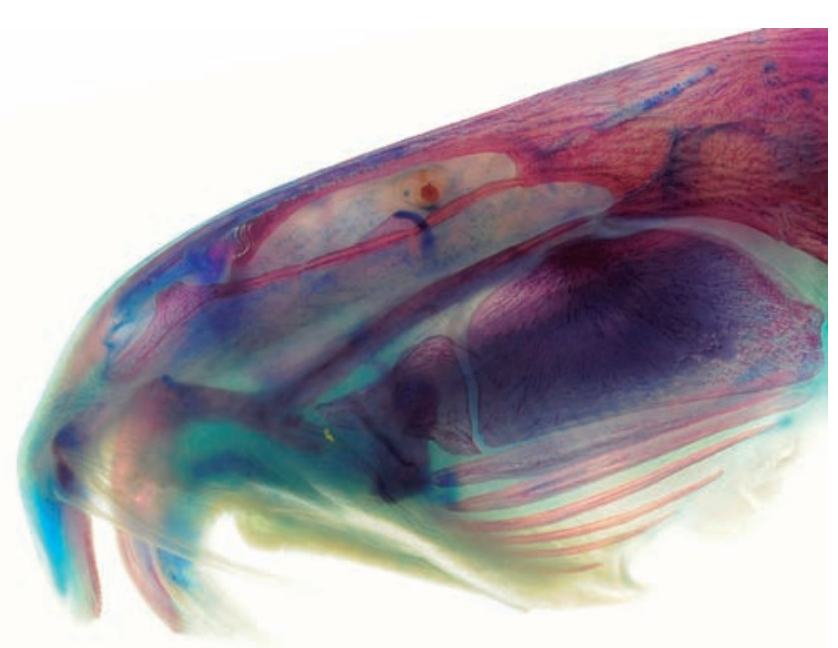

Fig. 40. Head in lateral view of a cleared and stained specimen of Rhynchodoras woodsi, ANSP 181042, 87 mm SL. Photo by Leandro Sousa. 
ventral margin forming a forceps-like beak (Fig. 40; Birindelli et al., 2007). That condition is absent in other examined taxa, in which the mandibular arch is more or less straight in lateral view.

125. Shape of premaxilla (unordered): 0- shaped like a plate, width distinctly greater than depth; 1 - conical with a dorsal apex, depth distinctly greater than width; 2- shaped like a block, depth and width approximately equal (CI 1.0, RI 1.0).

The premaxilla in most catfishes is shaped as a plate, with width distinctly greater than depth (Figs. 41a,b; Lundberg, 1970). In the doradids Anduzedoras, Doras, Hassar, Hemidoras, Leptodoras, Nemadoras, Ossancora, Oxydoras, Tenellus, and Trachydoras, the premaxilla is reduced in size and shaped as a cone with a dorsal apex, with depth distinctly greater than width (Figs. 41c,d; Higuchi, 1992: \#42, \#43). In the Mochokidae (except Acanthocleithron, Mochokiella, and Mochokus) the premaxilla is shaped as a block, with the depth and width approximately equal (Vigliotta, 2008: \#35, figs. 1214). The auchenipterids Epapterus and Pseudepapterus also have a reduced premaxilla, somewhat similar to that of fimbriate-barbel doradids, but shaped as a plate (state 0), whereas the auchenipterids Ageneiosus, Asterophysus, and Tetranematichthys have an extremely elongate premaxilla, shaped as a plate (state 0; Britski, 1972: 15; Royero, 1999: \#57), and associated with an elongated dentary (Ferraris, 1988: \#J9; Akama, 2004: \#51). The auchenipterid Gelanoglanis also has premaxilla shaped as a plate (state 0 ), but very delicate, thin and posteriorly elongate, with teeth only on its anterior portion (Ferraris, 1988: \#J20; Rengifo et al., 2008).

126. Dorsolateral process of premaxilla: 0- absent; 1 - present (CI 0.25, RI 0.25).

In the Claroteidae, Heptapteridae, Pimelodidae, Pseudopimelodidae, and Sisoridae, the premaxilla has a dorsolateral process articulated with the maxilla (de Pinna, 1993: \#40; Britto, 2002: \#135). That process is absent in other examined taxa. This character was coded as missing data for the auchenipterid Spinipterus.

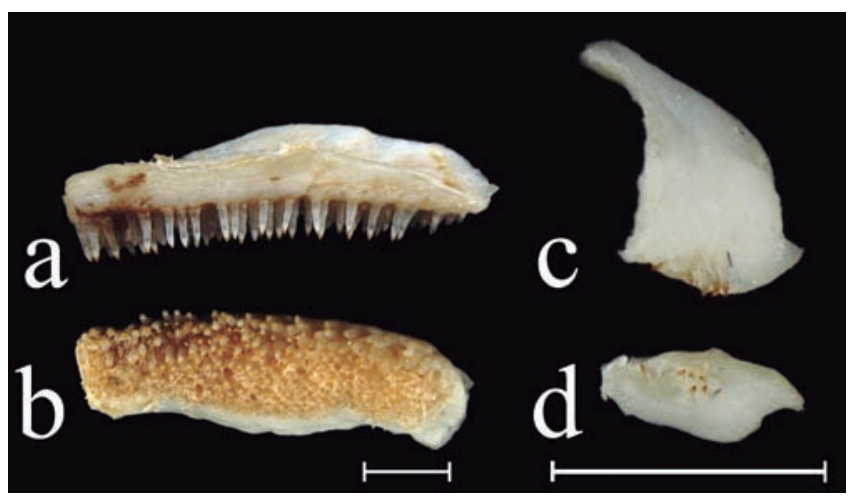

Fig. 41. Premaxilla in anterior (a,c) and ventral (b,d) views of (a,b) Pterodoras granulosus, MZUSP 91655, 410 mm SL; (c,d) Doras higuchii, MZUSP 101693, 172 mm SL. Scale bars equal $5 \mathrm{~mm}$.
127. Lateroposterior extension of premaxilla: 0 - absent; 1 present (CI 0.2, RI 0.0).

In the auchenipterids Auchenipterus and Epapterus, the premaxilla has a distinct lateroposterior extension (Ferraris, 1988: \#J21; Akama, 2004: \#54). The same condition is present in the Heptapteridae, Pimelodidae, and Pseudopimelodidae, but is absent in other examined taxa. This character was coded as missing data for the auchenipterid Spinipterus.

128. Premaxillary teeth (ordered): 0 - more than 30; 1 - reduced in number (less than 30); 2- absent (CI 0.2, RI 0.867).

Most catfishes have numerous teeth on the premaxilla. However, the auchenipterids Auchenipterus and Entomocorus have premaxillary teeth reduced in number and arranged in only one to three rows (Ferraris, 1988: \#J7; Ferraris \& Vari, 1999; Akama, 2004: \#49). The doradids Doras carinatus, D. higuchii, D. micropoeus (Sabaj Pérez \& Birindelli, 2008), Hassar, Hemidoras stenopeltis and Ossancora also have premaxillary teeth reduced in number (Figs. 41c,d). The premaxillary teeth are absent in the adults of the auchenipterids Epapterus and Pseudepapterus (Ferraris, 1988: \#J8), and doradids Anduzedoras, Doras phlyzakion, D. zuanoni, Hemidoras morei, H. morrisi, H. stubelii, Leptodoras, Nemadoras, Oxydoras, Tenellus, and Trachydoras (Eigenmann, 1925: 282; Higuchi, 1992: \#42; Sabaj, 2002: \#13). Among other examined catfishes, premaxillary teeth are also absent in the Aspredinidae (de Pinna, 1996: \#7).

129. Shape of premaxillary teeth: 0 - slightly curved; 1 - Sshaped (CI 1.0, RI 1.0).

Most catfishes have slightly curved teeth, however, the species of Mochokidae (except Acanthocleithron, Mochokiella, and Mochokus) have long S-shaped premaxillary teeth (Vigliotta, 2008: \#37). This character was coded as inapplicable for all taxa with an edentulous premaxilla (i.e., Aspredinidae, auchenipterids Epapterus and Pseudepapterus, and doradids Anduzedoras, Doras phlyzakion, D. zuanoni, Hemidoras morei, $H$. morrisi, $H$. stubelii, Leptodoras, Nemadoras, Oxydoras, Tenellus, and Trachydoras).

130. Premaxillary teeth: 0 - similar in size; 1 - with at least two distinct sizes (CI 1.0, RI 1.0).

Most catfishes have similarly sized teeth, however, the species of Mochokidae (except Acanthocleithron, Mochokiella, and Mochokus) have premaxillary teeth of at least two distinct sizes separated into discrete patches (Vigliotta, 2008: \#36). This character was coded as inapplicable for all taxa with an edentulous premaxilla (i.e., Aspredinidae, auchenipterids Epapterus and Pseudepapterus, and doradids Anduzedoras, Doras phlyzakion, D. zuanoni, Hemidoras morei, H. morrisi, H. stubelii, Leptodoras, Nemadoras, Oxydoras, Tenellus, and Trachydoras).

131. Size of maxilla: 0- short; 1 - elongate, rod-like (CI 0.1430.167, RI 0.829-0.857). 
Most catfishes have a short maxilla. However, members of the Siluridae, Sisoridae, and auchenipterids Auchenipterus, Centromochlus heckelii, Gelanoglanis, Entomocorus, Epapterus, and Pseudepapterus (Ferraris, 1988: \#J11) and doradids Anduzedoras, Doras, Hassar, Hemidoras, Leptodoras, Nemadoras, Oxydoras, Tenellus, and Trachydoras all have an elongate, rod-like maxilla (Figs. 25, 27, 33b; Higuchi, 1992: \#44; Sousa, 2010: \#33).

132. Number of heads at articular end of maxilla: 0- two; 1one (CI and RI inapplicable).

In most catfishes the maxilla has two proximal heads that form a bifurcated condyle (ventralmost head usually more developed). However, in the Cetopsidae, Diplomystidae, Scoloplacidae, and Trichomycteridae the maxilla articulates with the autopalatine via a single condyle (Arratia, 1992: \#3, \#4, \#5; Britto, 2002: \#145; de Pinna et al., 2007: \#2). Some authors (e.g., Mo, 1991: \#25; Britto, 2002: \#145) have considered the dorsal head to be more developed in the Auchenipteridae, Doradidae, and mochokids Synodontis, compared to other catfishes, but that condition was not observed in the specimens examined. This character was coded as missing data for the auchenipterid Spinipterus.

133. Maxillary teeth: 0- present; 1- absent (CI and RI inapplicable).

An edentulous maxilla is present in all catfishes except the Diplomystidae (Regan, 1911: 556; Alexander, 1965: 91; Lundberg, 1970; Arratia, 1987; Arratia, 1992: \#1). This feature has long been regarded as a primitive trait of the Diplomystidae (de Pinna, 1993: 53; Grande \& de Pinna, 1998; Britto, 2002: \#148; Diogo, 2004: \#259; de Pinna et al., 2007: \#3).

134. Shape of maxilla of mature males: 0 - similar to those in females and immature males; 1 - elongate, longer than in females and immature males (CI 0.333, RI 0.6).

Among examined species, the maxilla in mature males is elongate and proprotionally longer than that in mature females and immature males only in the auchenipterids Auchenipterus, Entomocorus, Epapterus, Pseudepapterus, Tetranematichthys and in some species of Trachelyopterus, including T. galeatus (Fig. 42b; Ferraris, 1988: \#J13; Akama, 2004:\#171). The increase in size of the maxilla in mature males is often associated with a similar enlargement of the autopalatine (Ferraris, 1988: \#J5; Walsh, 1990: \#15; Akama, 2004: \#175). This character was coded as missing data for Pseudotatia and Spinipterus.

135. Spines on maxilla of mature males: 0 - absent; 1 - present (CI 1.0, RI 1.0).

Among examined species, only in the auchenipterid Ageneiosus the maxilla of mature males has spines (Fig. 42a; Ferraris, 1988: \#J15; Walsh, 1990: \#22; Royero, 1999: \#129, \#130; Akama, 2004: \#172), a dimorphic feature. This character was coded as missing data for Pseudotatia and Spinipterus.
136. Coronomeckelian bone: 0- present; 1 - absent (CI 0.5, RI 0.75).

Among catfishes the coronomeckelian bone is absent only in the Astroblepidae, Callichthyidae, aspredinids Hoplomyzontinae, Loricariidae, Malapteruridae, Mochokidae, and Scoloplacidae (Arratia, 1992: \#47; de Pinna, 1993: \#23; Diogo, 2004: \#424; Vigliotta, 2008: \#26). This character was coded as missing data for the auchenipterid Spinipterus.

137. Contact between coronomeckelian bone and dentary: 0absent; 1- present (CI 0.25, RI 0.927).

In most catfishes, the coronomeckelian bone is a small bony bridge surrounding the meckelian cartilage and extended immediately posterior to the mandibular ramus of the facial nerve (Fig. 43b). However, in the doradids Anduzedoras, Doras, Franciscodoras, Hassar, Hemidoras, Kalyptodoras, Leptodoras, Nemadoras, Orinocodoras, Ossancora, Oxydoras, Platydoras sp., Rhinodoras, Rhynchodoras, Tenellus, Trachydoras, Wertheimeria, and some specimens of Pterodoras granulosus (Fig. 43a; de Pinna, 1993: \#51; Britto, 2002: \#159; Sousa, 2010: \#35), the coronomeckelian bone is anteriorly extended, surrounding the mandibular ramus of the

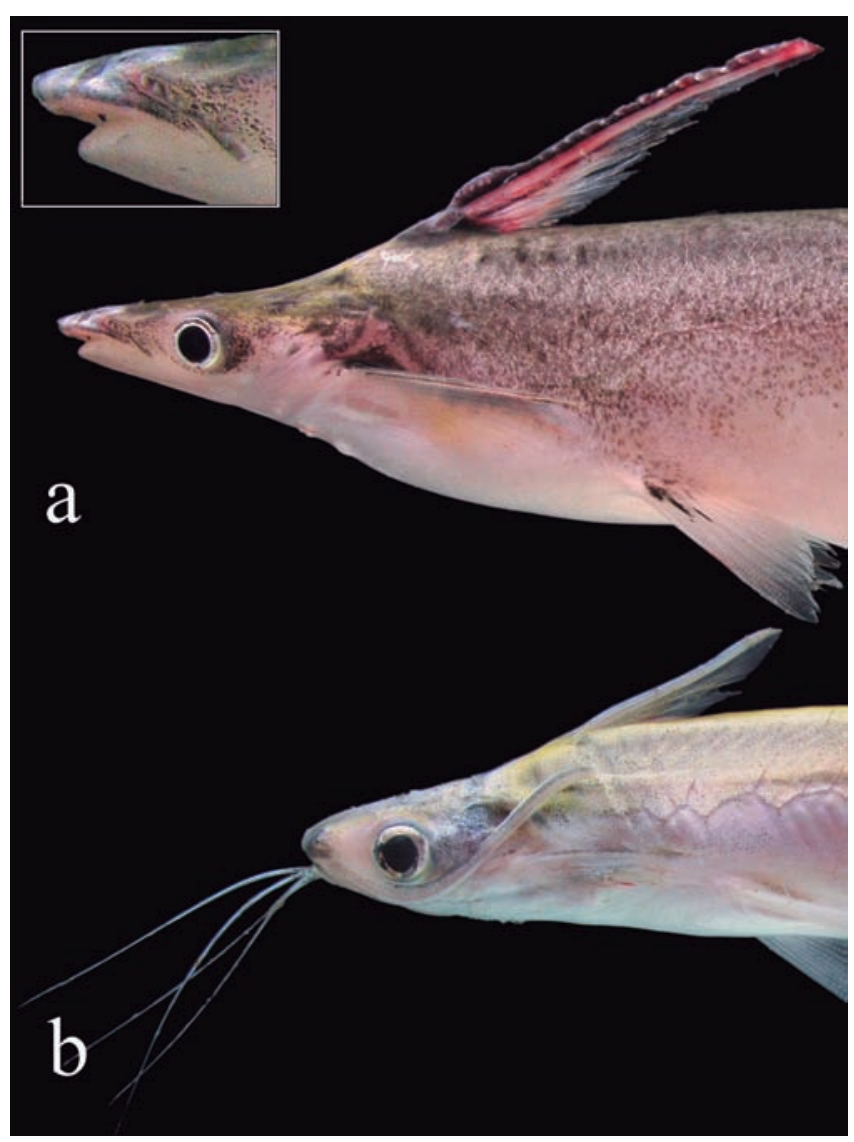

Fig. 42. Head and anterior portion of body in lateral view of mature males of (a) Ageneiosus ucayalensis, MZUSP104791, $171 \mathrm{~mm}$ SL (snout in detail, showing maxilla with spines); (b) Auchenipterus osteomystax, MZUSP 103352, 133 mm SL. Both collected at rio Jari, Monte Dourado, Pará, photographed live. 


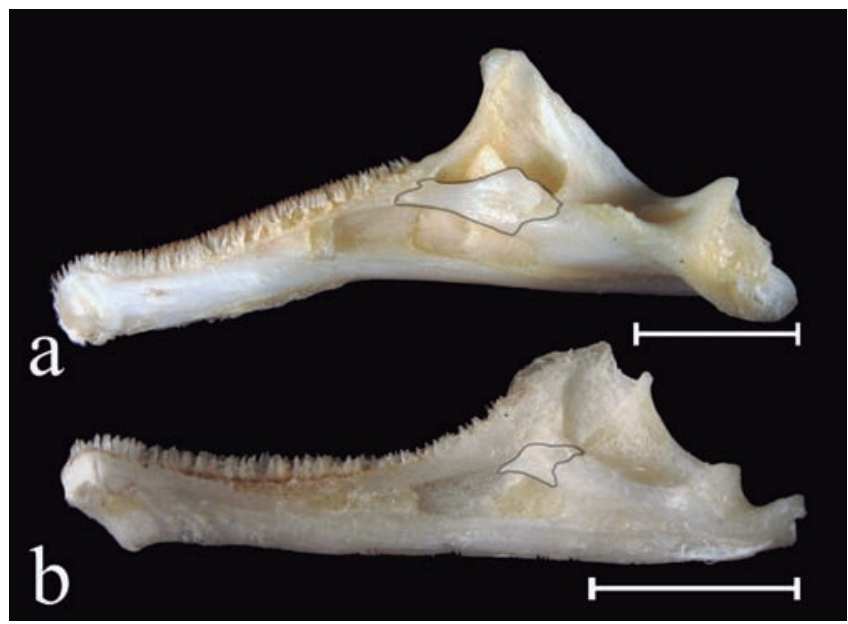

Fig. 43. Lower jaw in medial view of (a) Wertheimeria maculata, MZUSP 93659, 217 mm SL; (b) Liosomadoras oncinus, MZUSP 105828, 110 mm SL. Scale bars equal 10 mm. Coronomeckelian bone outlined.

facial nerve and contacting the dorsal border of the dentary. This character was coded as polymorphic for Pterodoras granulosus; as inapplicable for the Malapteruridae and Mochokidae; and as missing data for Spinipterus.

138. Ascending process of Meckel's cartilage: 0- present; 1absent (CI 0.25, RI 0.571).

Among specimens examined, the ascending process of the Meckel's cartilage is absent only in the Amphiliidae, Malapteruridae, Mochokidae, Nematogenyidae and Siluridae (Mo, 1991: \#35; de Pinna, 1993: \#22; Britto, 2002: \#155; Diogo, 2004: \#419; Vigliotta, 2008: \#24). This character was coded as missing data for the auchenipterid Spinipterus.

139. Coronoid process of lower jaw: 0- present; 1- absent (CI 0.5, RI 0.75).

Among examined specimens, the coronoid process of the lower jaw is absent only in the Mochokidae and auchenipterid Asterophysus (de Pinna, 1993: \#50; Britto, 2002: \#151; Diogo, 2004: \#400; Vigliotta, 2008: \#27). In the Siluridae, this process is extremely small, but present. This character was coded as missing data for the auchenipterid Spinipterus.

140. Angle between lower jaws: 0 - approximately $90^{\circ}$; 1 between $135^{\circ}$ and $180^{\circ}$ (CI 1.0, RI 1.0).

In the examined species of the Mochokidae (except Acanthocleithron, Mochokiella, Mochokus, and Synodontis membranaceus) the lower jaws meet at an angle between $135^{\circ}$ and $180^{\circ}$ (Vigliotta, 2008: \#28). The same condition is present in the Loricariidae. In all other examined species, the lower jaws are arranged in an angle of approximately $90^{\circ}$.

141. Connective tissue parallel to primordial ligament: 0 absent; 1- present (CI 1.0, RI 1.0).

In members of the Anchariidae, Ariidae, Auchenoglanidae, and Claroteidae, there is a connective tissue sheath parallel to the primordial ligament, associated with both the coronoid process of the lower jaw and the maxillary barbel (Mo, 1991: \#28; de Pinna, 1993: \#29; Royero, 1999: \#145; Britto, 2002: \#150; Marceniuk et al., 2012: \#112). This feature is absent in other catfishes. This character was coded as missing data for the auchenipterid Spinipterus.

142. Ventral process of dentary: 0 - absent; 1 - present (CI 0.333, RI 0.6).

In the Malapteruridae, ariid Genidens (Marceniuk et al., 2012: \#108), and the auchenipterids Auchenipterus, Entomocorus, Epapterus, and Pseudepapterus, one or two ventral processes are present on the dentary. Those processes are probably associated with the mental barbels (Fig. 30; Ferraris, 1988: \#J17; Akama, 2004: \#53). In all other examined specimens those processes are absent. This character was coded as missing data for the auchenipterid Spinipterus.

143. Dentary teeth (ordered): 0 - numerous (50 or more); 1 reduced in number (less than 50); 2- absent (CI 0.286, RI 0.894).

Most catfishes have numerous small teeth arranged in several rows on the dentary (Fig. 43). However, reduction in the number of teeth on the dentary occurs in some species. The doradids Anduzedoras, Doras carinatus, D. higuchii, D. micropoeus, Hassar, Hemidoras stenopeltis, H. stubelii, Nemadoras, Ossancora, Tenellus and some specimens of Doras phlyzakion, Leptodoras praelongus, and L. juruensis have fewer than 50 teeth on the dentary (Higuchi, 1992: \#49, \#A41). The auchenipterids Auchenipterus and Entomocorus have also reduced number of teeth arranged in few rows on dentary (Ferraris, 1988: \#J8; Akama, 2004: \#50). The auchenipterids Epapterus and Pseudepapterus, and doradids Hemidoras morei, H. morrisi, Leptodoras marki, L. oyakawai, Oxydoras, Trachydoras and some specimens of Doras phlyzakion, Leptodoras juruensis and L. praelongus have an edentulous dentary (Higuchi, 1992: \#48; Sabaj, 2002: \#14). This character was coded as polymorphic $(1,2)$ for Doras phlyzakion, Leptodoras juruensis and L. praelongus.

144. Insertion of dentary teeth: 0 - inserted directly on surface of dentary; 1 - inserted in a depression of the dentary (CI 1.0, RI 1.0).

In most catfishes, the teeth are inserted directed on the surface of the dentary bone (Fig. 43). However, in all species of the Mochokidae (except Mochokiella and Mochokus), the dentary has a deep depression that supports the teeth (Vigliotta, 2008: \#30,\#32). A similar condition occurs in the Amphiliidae, Loricariidae, and Astroblepidae (de Pinna, 1993: \#49; Britto, 2002: \#160; Diogo, 2004: \#396).

145. Ventral process on symphysis of dentary: 0- absent; 1 present (CI 0.5, RI 0.667).

Members of the Anchariidae, Ariidae, Auchenoglanidae, Callichthyidae, Claroteidae, Malapteruridae, and Schilbeidae have a ventral process on the symphysis of the dentary, onto which the intermandibularis muscle is attached (Britto, 2002: 
\#162). That process is absent in other examined taxa. This character was coded as missing data for the auchenipterid Spinipterus.

\section{Suspensorium.}

146. Anterior condyle of autopalatine: 0 - double; 1 - single (CI and RI inapplicable).

In the Diplomystidae, the autopalatine has a double condyle anteriorly for articulation with the maxilla (Lundberg, 1970; Arratia, 1987; Arratia, 1992: \#9; Grande \& de Pinna, 1998; Britto, 2002: \#171). In all other catfishes the autopalatine has a single condyle anteriorly. This character was coded as missing data for the auchenipterid Spinipterus.

147. Shape of autopalatine: 0 - depressed, with wide anterior end; 1- cylindrical, anterior end not distinctly enlarged (CI 1.0, RI 1.0).

In the Diplomystidae and Nematogenyidae the autopalatine is depressed and has a wide anterior end (Arratia, 1992: \#7; Marceniuk et al., 2012: \#98). The autopalatine is more or less uniformly cylindrical in all other catfishes. This character was coded as missing data for the auchenipterid Spinipterus.

148. Length of autopalatine: 0 - relatively short, length of autopalatine smaller than length of lower jaw; 1- relatively long, length of autopalatine greater than length of lower jaw (CI 0.5, RI 0.974).

In most catfishes, the autopalatine is relatively short, shorter than the the lower jaw (Figs. 20-21, 23, 28, 33a). However, in the doradids Anduzedoras, Centrodoras brachiatus, Doras, Hassar, Hemidoras, Leptodoras, Nemadoras, Orinocodoras, Ossancora, Oxydoras, Rhinodoras, Rhynchodoras, Tenellus, and Trachydoras, it is extremely elongate and distinctly longer than the lower jaw (Figs. 25, 27, 33b; Eigenmann, 1925: 286; Higuchi, 1992: \#47; Sousa, 2010: \#34). This character was coded as missing data for the auchenipterid Spinipterus.

149. Posterior limit of autopalatine: 0 - anterior orbital margin; 1- approximately at vertical through middle of orbit (CI 0.5, RI 0.833).

The posterior limit of the autopalatine is anterior to the orbital margin in most examined species, including the doradids Anduzedoras, Doras, Hassar, Hemidoras, Leptodoras, Nemadoras, Ossancora, Oxydoras, Tenellus, and Trachydoras that have an elongate autopalatine (Figs. 20-22, 26-28). However, the posterior limit of the autopalatine lies near the middle of the orbit in the Diplomystidae, and doradids Orinocodoras, Rhinodoras and Rhynchodoras (Fig. 40; Higuchi, 1992: \#A40; Birindelli et al., 2007). This character was coded as missing data for the auchenipterid Spinipterus.

150. Position of articular facet of autopalatine: 0 - dorsal; 1 lateral (CI 1.0, RI 1.0).

Among catfishes, the articular facet of the autopalatine is dorsal only in the Cetopsidae, Diplomystidae, and Loricarioidei, all of which are widely regarded as relatively basal members of the Siluriformes (Lundberg, 1970; Mo, 1991: \#3; de Pinna, 1993: \#59; Grande \& de Pinna, 1998; Britto, 2002: \#13; Diogo, 2004: \#296; de Pinna et al., 2007: \#14). This character was coded as missing data for the auchenipterid Spinipterus.

151. Length of anterior cartilage of autopalatine: 0 - short, length distinctly smaller than that of ossified portion of autopalatine; 1- long, length nearly equal to, or greater than, that of ossified portion of autopalatine (CI 1.0, RI 1.0).

Among examined catfishes, the anterior cartilage of the autopalatine is extremely elongate (nearly equal to or greater than of the ossified portion of the autopalatine) only in the Anchariidae, Ariidae and Claroteidae (Mo, 1991; de Pinna, 1993: \#25; Britto, 2002: \#172; Diogo, 2004: \#277; Marceniuk et al., 2012: \#106). This character was coded as missing data for the auchenipterid Spinipterus.

152. Posterior cartilage of autopalatine: 0 - present; 1 - absent (CI 0.5, RI 0.0).

Among examined catfishes the posterior cartilage of the autopalatine is absent only in the Malapteruridae, mochokids Chiloglanidinae and some specimens of Amphilius jacksoni (Amphiliidae) (Mo, 1991; Arratia, 1992; de Pinna, 1993: \#21; Diogo, 2004: \#283; Vigliotta, 2008: \#41). This character was coded as polymorphic for Amphilius jacksoni. This character was coded as missing data for the auchenipterid Spinipterus.

153. Medial lamina of hyomandibula: 0 - present; 1 - absent (CI 1.0, RI 1.0).

In most catfishes, the hyomandibula is an elongate bone with a medial lamina that supports the insertion of most of the adductor mandibulae muscle (Fig. 44). In the doradids Anduzedoras, Doras, Hassar, Hemidoras, Leptodoras, Nemadoras, Ossancora, Tenellus, and Trachydoras the hyomandibula is extremely elongate and lacks the medial lamina (Figs. 26, 27; Higuchi, 1992: \#54). This character was coded as missing data for the auchenipterid Spinipterus.

154. Hyomandibular crest for levator arcus palatini muscle (ordered): 0- absent or rudimentary; 1- weakly developed; 2well developed (CI 0.286, RI 0.839).

In several catfishes, including among examined taxa the Auchenipteridae, Bagridae, Cetopsidae, Claroteidae, Diplomystidae, Ictaluridae, Nematogenyidae, Pangasiidae, Pseudopimelodidae, and doradid Franciscodoras, the hyomandibular crest, on which the levator arcus palatini muscle inserts, is weakly developed (Figs. 44a,b,c; Lundberg, 1970: \#62; Arratia, 1992: \#31). However, in the doradids Kalyptodoras and Wertheimeria the hyomandibular crest is developed as a distinct process (Fig. 44g). The hyomandibular crest is absent (Figs. 44h,i) in the Amphiliidae, Ariidae, Aspredinidae, Erethistidae, Heptapteridae, Malapteruridae, Mochokidae, Pimelodidae, Siluridae, and all species of Doradidae (except Franciscodoras, Kalyptodoras, and 
Wertheimeria). This character was coded as missing data for the auchenipterid Spinipterus.

155. Orientation of hyomandibular crest for levator arcus palatini muscle: 0- horizontal; 1- vertical (CI 1.0, RI 1.0).

In the Bagridae, Cetopsidae, Claroteidae, Diplomystidae, Ictaluridae, Pangasiidae, Pseudopimelodidae, the hyomandibular crest is horizontal, parallel to the body axis. However, in the Auchenipteridae, Nematogenyidae, and doradids Franciscodoras, Kalyptodoras and Wertheimeria the hyomandibular crest, on which the levator arcus palatini muscle inserts, is vertical relative to the body axis (Figs. 44a,b,c,g; Lundberg, 1970; Arratia, 1992: 117). This character was coded as inapplicable for the Amphiliidae, Ariidae, Aspredinidae, Erethistidae, Heptapteridae, Malapteruridae,
Mochokidae, Pimelodidae, Siluridae, and all species of Doradidae (except Franciscodoras, Kalyptodoras, and Wertheimeria); and as missing data for the auchenipterid Spinipterus.

156. Hyomandibular crest for Aw section of adductor mandibulae muscle: 0- absent; 1- present (CI 1.0, RI 1.0).

In the doradids Orinocodoras, Rhinodoras, and Rhynchodoras there is a distinct crest on the hyomandibula, on which the Aw section of the adductor mandibulae muscle is inserted (Fig. 44h). That crest is absent in other examined taxa (Fig. 44a-c, g-h). This character was coded as missing data for the auchenipterid Spinipterus.

157. Hyomandibular process for adductor mandibulae

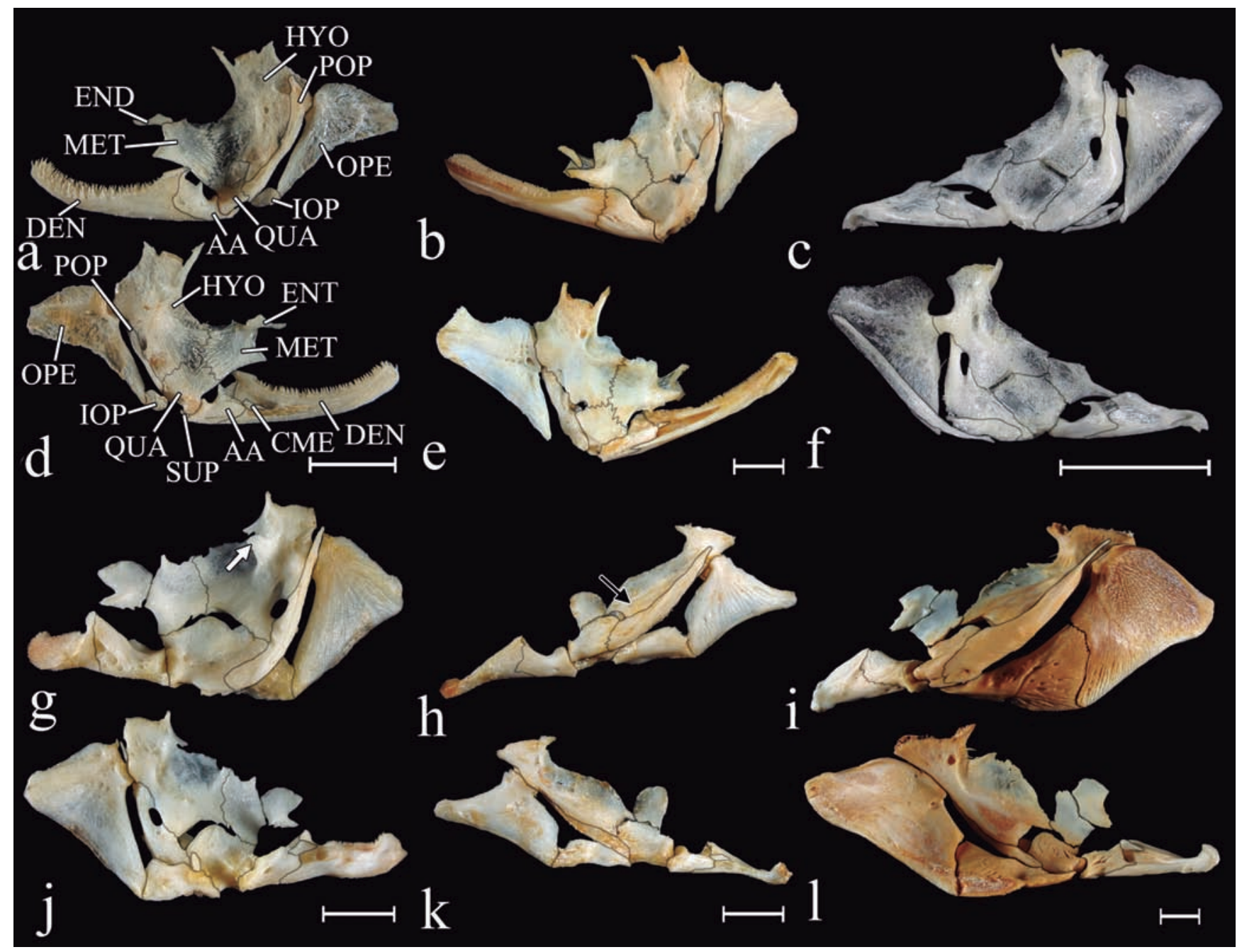

Fig. 44. Suspensorium in lateral (a-c,g-i) and medial (d-f,j-l) views of (a,d) Glanidium melanopterum, MZUSP 64256, $112 \mathrm{~mm}$ SL; (b,e) Trachycorystes trachycorystes, MZUSP 91659, 200 mm SL; (c,f) Auchenipterus nuchalis, MZUSP 97375, 117 mm SL; (g,j) Wertheimeria maculata, MZUSP 93659, 217 mm SL; (h,k) Rhinodoras dorbignyi, MZUSP 40109, 196 mm SL; (i,l) Oxydoras niger, MZUSP 91654, 550 mm SL. AA anguloarticular, CME coronomeckelian bone, DEN dentary, ENT entopterygoid, HYO hyomandibula, IOP interopercle, MET metapterygoid, OPE opercle, POP preopercle, QUA quadrate, SUP subpreopercle. White arrow indicates hyomandibular crest for attachment of muscle levator arcus palatini, black arrow indicates hyomandibular crest for section Aw of muscle adductor mandibulae. Scale bars equal $10 \mathrm{~mm}$. 
muscle: 0- absent or rudimentary; 1 - well developed (CI 0.333, RI 0.6).

The hyomandibula has a distinct and well-developed process, on which the adductor mandibulae muscle inserts, that is positioned dorsal to the articulation between the hyomandibula and the opercle in the Ariidae, Claroteidae, Ictaluridae, Pangasiidae and Pimelodidae (Lundberg, 1970: 36; Pinna, 1993: \#92; Britto, 2002: \#184). This process is rudimentary (or absent) in all other examined species (Fig. 44). This character was coded as missing data for the auchenipterid Spinipterus.

158. Medial process of hyomandibula: 0 - absent; 1 - present (CI 0.5, RI 0.0).

In the mochokids Microsynodontis, Mochokiella and several species of Synodontis (including S. schall) there is a medial process on the hyomandibula (Vigliotta, 2008: \#42), that is absent in other examined taxa (Fig. 44). The association between this process and muscles of the suspensorium has not been determined. This character was coded as missing data for the auchenipterid Spinipterus.

159. Posterodorsal process of hyomandibula: 0- absent; 1 present (CI 0.25, RI 0.8).

In all auchenipterids, except Asterophysus, Auchenipterus, Entomocorus, Epapterus, Gelanoglanis, and Pseudepapterus, there is a distinct posterodorsal process on the hyomandibula, posterior to the articulation between the hyomandibula and cranium (Figs. 44a,b; Royero, 1999: \#61; Akama, 2004: \#56). That process is absent in all other examined taxa (Fig. 44c,g-i). This character was coded as missing data for Spinipterus.

160. Hyomandibular condyle for opercle: 0 - on a short process, which is shorter than the anterodorsal process of hyomandibula; 1- on a long process, which is longer than the anterodorsal process of hyomandibula (CI 0.5, RI 0.75).

In the Aspredinidae and auchenipterids Auchenipterus, Entomocorus, Epapterus, and Pseudepapterus (de Pinna, 1996: \#23), the hyomandibular condyle for the opercle is located on a distinctly elongated process, which is longer than the anterodorsal process of hyomandibula (Fig. 44c, f; Royero, 1999: \#63; Akama, 2004: \#58). In all other examined taxa, the hyomandibular condyle for the opercle is located on a short process (Fig. 44d-e,j-l). This character was coded as missing data for the auchenipterid Spinipterus.

161. Number of openings in hyomandibula for a hyomandibular branch of trigeminofacial nerve: 0 - one; 1 two (CI 1.0, RI 1.0).

In most catfishes, there is a single opening in the hyomandibula for the passage of the hyomandibular branch of the trigeminofacial nerve (Fig. 44a,c). However, there are two opening in the auchenipterids Trachelyopterus coriaceus, T. galeatus, and Trachycorystes (Fig. 44b; Royero, 1999: \#60; Akama, 2004: \#55). This character was coded as missing data for the auchenipterid Spinipterus.

162. Articulation between hyomandibula and cranium (ordered): 0- through sphenotic, pterotic and prootic; 1through sphenotic and pterotic; 2- only through sphenotic (CI 0.167, RI 0.545).

In most catfishes, the articulation between the hyomandibula and cranium is through the pterotic and sphenotic (Fig. 33b; Mo, 1991: \#21; Arratia, 1992: \#35; Royero, 1999: \#56; Britto, 2002: \#181). However, in the Diplomystidae, Nematogenyidae and Mochokidae (except Mochokus) the articulation also occurs through the prootic (Alexander, 1965: 97; Arratia, 1992: \#35; Vigliotta, 2008: \#10). On the other hand, in the Amphiliidae, Ariidae, Erethistidae, auchenipterids Asterophysus, Auchenipterichthys, Auchenipterus, Entomocorus, Epapterus, Pseudepapterus, Tatia, Trachelyopterichthys, Trachelyopterus and Trachycorystes, and doradids Acanthodoras and Agamyxis, Kalyptodoras, and Wertheimeria, the hyomandibula articulates with the cranium only via the sphenotic (Fig. 33a). This character was coded as missing data for the auchenipterid Spinipterus.

163. Dorsomedial lamina of quadrate: 0 - absent; 1 - present (CI 0.5, RI 0.667).

Among examined species, the quadrate possesses a distinct dorsomedial lamina only in the auchenipterids Ageneiosus, Centromochlus existimatus, C. heckelii and Tetranematichthys (Fig. 31; Ferraris, 1988: \#J2; Walsh, 1990: \#1; Soares-Porto, 1998: \#13; Royero, 1999: \#55, \#59; Akama, 2004: \#47). This character was coded as missing data for the auchenipterid Spinipterus.

164. Hyomandibula and metapterygoid: 0- in contact; 1separated (CI 0.143, RI 0.842).

In most catfishes, the hyomandibula articulates with the metapterygoid (Fig. 44). However, in the Amphiliidae, Aspredinidae, Claroteidae, Heptapteridae, Malapteruridae, doradids Anduzedoras, Doras, Hassar, Hemidoras, Leptodoras, Nemadoras, Ossancora, Tenellus and Trachydoras, and auchenipterids Centromochlus, Tetranematichthys, Ageneiosus, and some specimens of Tatia aulopygia (Britski, 1972: 23), the hyomandibula and metapterygoid are not in contact (Figs. 26, 27, 31; Arratia, 1992: \#25; Britto, 2002: \#189). Alexander (1965) considered this lack of contact directly associated to the enlargement of the eye. This character was coded as polymorphic for the auchenipterid Tatia aulopygia; and as missing data for the auchenipterid Spinipterus.

165. Size of entopterygoid: 0 - relatively small, smaller than metapterygoid; 1 - relatively large, larger than metapterygoid (CI 1.0, RI 1.0).

Although its homology remains an unsettled subject in catfish anatomy (Arratia, 1992), the entopterygoid (or ‘entopterygoid' of types 3-7 of Arratia, 1992: fig. 2, formed by the ligament between metapterygoid and lateral ethmoid or 
vomer) is relatively small in most catfishes (Fig. 44; Britto, 2002:\#186; Arratia, 1992: \#20-21; Vigliotta, 2008: \#44). However, in the doradids Anduzedoras, Doras, Hassar, Hemidoras, Leptodoras, Nemadoras, Tenellus, and Trachydoras, the entopterygoid is relatively large, larger than the metapterygoid (Figs. 26, 27, 33b; Britski, 1972: 23; Higuchi, 1992: \#50, \#51; Sousa, 2010: \#41). This character was coded as inapplicable for the Claroteidae and mochokids Mochokiella and Mochokus (Vigliotta, 2008: \#44); and as missing data for the auchenipterid Spinipterus.

166. Ectopterygoid: 0- absent; 1 - present (CI 0.25, RI 0.5).

Most catfishes lack an ectopterygoid. However, the Ariidae, Bagridae, Claroteidae, Pangasiidae, Pimelodidae, Pseudopimelodidae, Sisoridae (Ferraris, 1988: \#J4; Arratia, 1992: \#18; Britto, 2002: \#188), and some specimens of Diplomystes (see Arratia, 1992), have an ectopterygoid. This character was coded as polymorphic for the Diplomystidae; and as missing data for the auchenipterid Spinipterus.

\section{Opercular series.}

167. Suprapreopercle: 0- absent; 1 - present (CI 0.2, RI 0.857).

In the Amphiliidae, Auchenipteridae (except Liosomadoras), Bagridae, Diplomystidae, Erethistidae, Malapteruridae, Ictaluridae, Nematogenyidae, Siluridae, and Sisoridae, there are one or more tubular bones (= suprapreopercles), between the preopercle and pterotic (Figs. 28, 29, 31; Britski, 1972: 21; Lundberg, 1970: \#70; Britto, 2002: \#196); this condition is absent in all other examined species (Figs. 20-27). This character was coded as missing data for the auchenipterid Spinipterus.

168. Subpreopercle: 0- absent; 1- present (CI 0.2, RI 0.556).

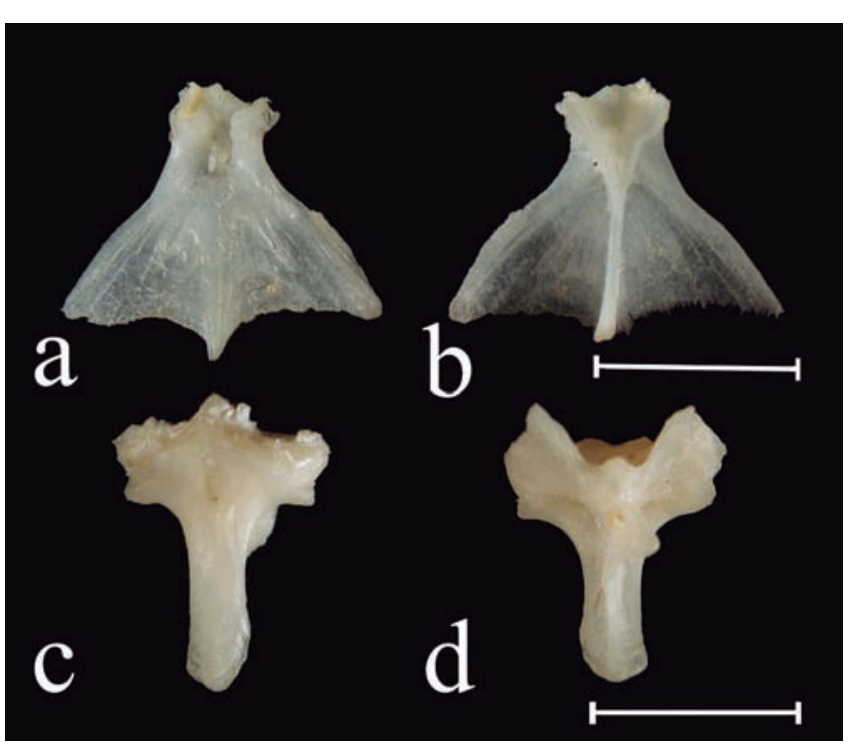

Fig. 45. Urohyal in ventral (a,c) and dorsal (b,d) views of (a,b) Ictalurus punctatus, MZUSP 103256, 155 mm SL; (c,d) Kalyptodoras bahiensis, MZUSP 87841, 233 mm SL. Scale bars equal $5 \mathrm{~mm}$.
Among examined species, only those of the Amphiliidae, Auchenipteridae, Bagridae, Cetopsidae, Diplomystidae, Doradidae, Erethistidae, Heptapteridae, Ictaluridae, Malapteruridae, Nematogenyidae, Pangasiidae, Pimelodidae and Sisoridae (Britto, 2002: \#197) have a small ossification between the preopercle and hyomandibula, the subpreopercle (Fig. 44b). This character was coded as missing data for the auchenipterid Spinipterus.

\section{Hyoid arch}

169. Lateral laminar wings of urohyal: 0 - present; 1 - absent (CI 1.0, RI 1.0).

The urohyal possesses lateral laminar wings in all catfishes (Figs. 45a,b; Lundberg, 1970; Arratia \& Schultze, 1990), except those of the Auchenipteridae, Doradidae and Mochokidae (Figs. 45c,d; Mo, 1991: \#39; de Pinna, 1993: \#239; Royero, 1999: \#146; Britto, 2002: \#81; Vigliotta, 2008: \#46). Diogo (2004: \#388) considered the urohyal of the mochokid Synodontis reduced. This character was coded as missing data for the auchenipterid Spinipterus.

170. Dorsal process of urohyal: 0 - absent; 1 - present (CI 0.5, RI 0.667).

In most catfishes, the dorsal face of the urohyal has a

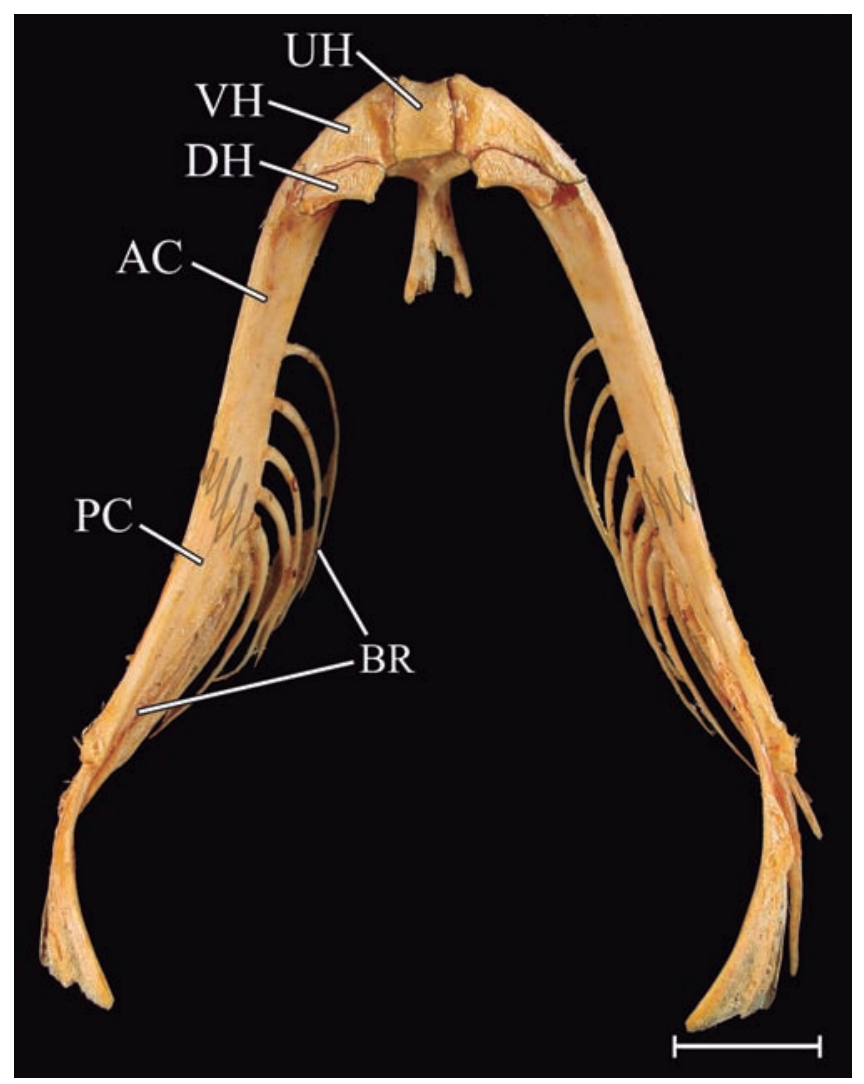

Fig. 46. Hyoid arch in dorsal view of Ageneiosus inermis, MZUSP 91661, 320 mm SL. AC anterior ceratobranchial, BR branchiostegal rays, DH dorsal hypohyal, PC posterior ceratohyal, UH urohyal, VH ventral hypohyal. Scale bar equals $10 \mathrm{~mm}$. 
small crest to which the paired ventral hypohyals are dorsally attached (Fig. 45b,d). However, in the auchenipterids Ageneiosus, Tetranematichthys, and Tocantinsia, the urohyal has a dorsal process located between and at the same level of the paired ventral hypohyals (Fig. 46; Ferraris, 1988: \#G7; Walsh, 1990: \#9; Akama, 2004: \#82). This process is extremely large in Ageneiosus inermis, and relatively small in Ageneiosus atronasus, A. brevis, A. ucayalensis, Tetranematichthys, and Tocantinsia. Although this feature was reported in the auchenipterids Auchenipterus and Entomocorus by Walsh (1990: \#9), and in the doradids Anduzedoras, Doras, Hassar, Hemidoras, Leptodoras, Nemadoras, Ossancora, Tenellus, and Trachydoras by Higuchi (1992: \#57), the dorsal process of the urohyal is not present in the examined specimens of those taxa. This character was coded as missing data for the auchenipterid Spinipterus.

171. Dorsal hypohyal: 0- present; 1 - absent (CI 0.2, RI 0.0).

In the Amphiliidae, Akysidae, Aspredinidae, Astroblepidae, Loricariidae, Pseudopimelodidae, Sisoridae, Trichomycteridae, and the mochokid Chiloglanis, the dorsal hypohyal is absent (Mo, 1991: \#43; Britto, 2002: \#75). Vigliotta (2008: \#47) considered the dorsal hypohyal to be fused into the ventral hypohyal, thus present, in the mochokids Atopodontus and Chiloglanis. However, the presence of a rudimentary dorsal hypohyal in small specimens of Chiloglanis polypogon examined herein suggests that the dorsal hypohyal is ontogenetically reduced and lost in those taxa, rather than fused into the ventral hypohyal. Based on the present observations, Chiloglanis was coded as 1 for this character. The dorsal hypohyal is present in all other examined species. This character was coded as missing data for Spinipterus.

172. Shape of ventral hypohyal: 0- rectangular, length distinctly smaller than width; 1- quadrangular, length and width approximately equal (CI 1.0, RI 1.0).

In most catfishes, the ventral hypohyal is rectangular, with length distinctly smaller than width (Figs. 47a,b). However, it is nearly a square, with the length and width approximately equal, in the doradids Anduzedoras, Doras, Hassar,

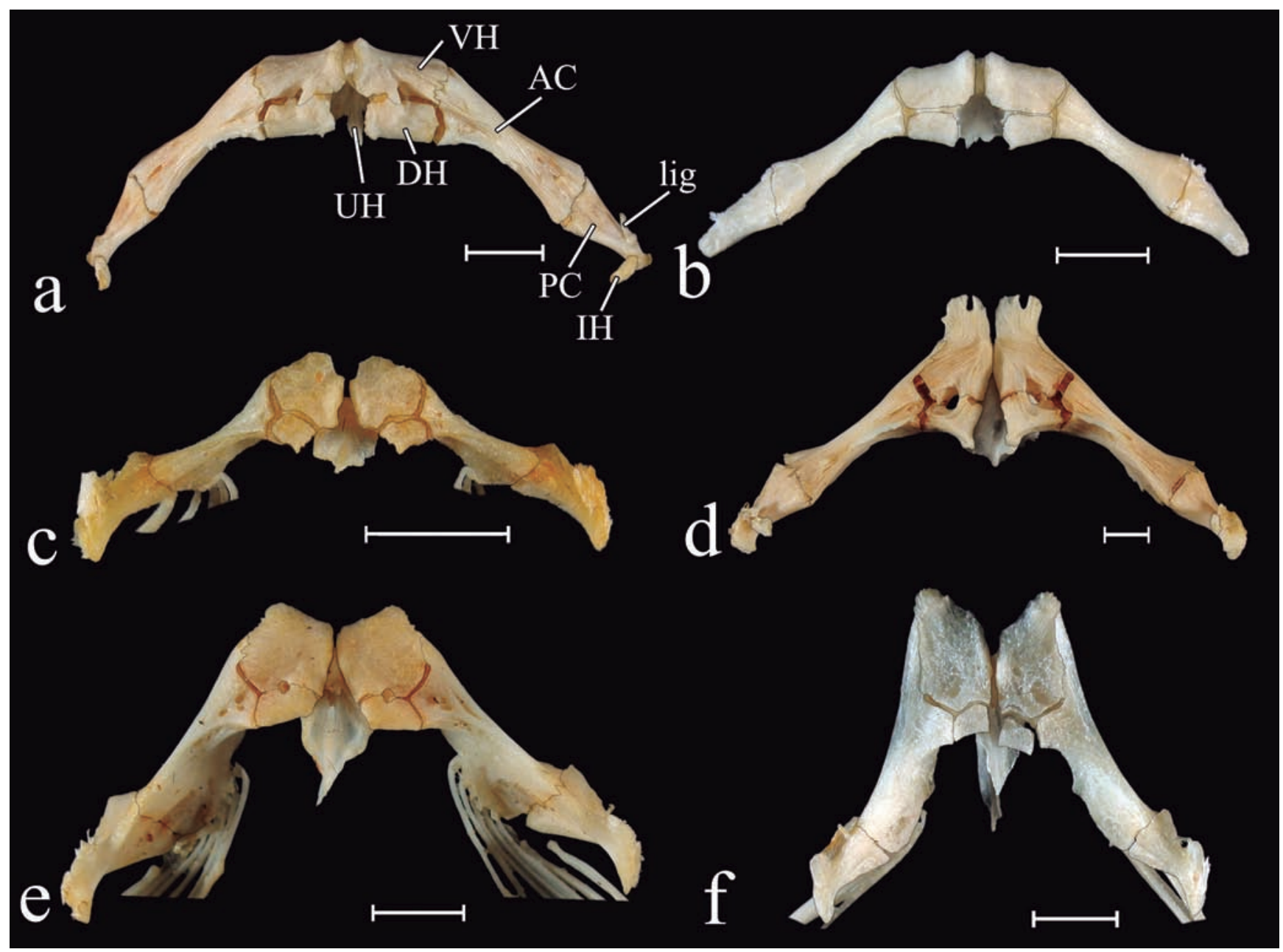

Fig. 47. Hyoid arches in dorsal view of (a) Pterodoras granulosus, MZUSP 91655, 410 mm SL; (b) Kalyptodoras bahiensis, MZUSP 87842, 152 mm SL; (c) Trachydoras brevis, MZUSP 103087, 74 mm SL; (d) Oxydoras niger, MZUSP 91658, 313 mm SL; (e) Doras higuchii, MZUSP 96334, 165 mm SL; (f) Hemidoras morei, MZUSP 32526, 153.2 mm SL. AC anterior ceratobranchial, DH dorsal hypohyal, IH interhyal, lig ligament, PC posterior ceratohyal, UH urohyal, VH ventral hypohyal. Scale bar equals 10 mm. 
Hemidoras, Leptodoras, Nemadoras, Ossancora, Oxydoras, Tenellus, and Trachydoras (Figs. 47c-f). This character was coded as missing data for the auchenipterid Spinipterus.

173. Anterior margin of ventral hypohyal: 0 - smooth, without spines; 1- with spines (CI 0.5, RI 0.955).

In the doradids Anduzedoras, Doras, Hassar, Hemidoras, Leptodoras, Nemadoras, Oxydoras and Tenellus, the anterior margin of the ventral hypohyal has spines (Figs. 47d-f). The same condition is present in Leptodoras oyakawai, although not illustrated by Birindelli et al. (2008), due to the angle for which the bone was illustrated. In all other examined species, the anterior margin of ventral hypohyal is straight, without spines (Fig. 47a-c). This character was coded as missing data for the auchenipterid Spinipterus.

174. Anterior portion of anterior ceratohyal (ordered): 0without anterior process; 1 - with small anterior process sutured to ventral hypohyal (suture occupying less than half of lateral border of ventral hypohyal); 2- with long anterior process sutured to ventral hypohyal (suture occupying more than half of border of ventral hypohyal) (CI 0.5, RI 0.952).

In most catfishes, the anterior ceratohyal does not have an anterior process, being connected to the ventral hypohyal mostly via cartilage, suturing restricted to a small portion of the anterior face and present only in larger specimens (Figs. 47a,b; Lundberg, 1970). However, in the doradids Anduzedoras, Doras, Hassar, Leptodoras, Ossancora, and Trachydoras, and there is a small anterior process of the ceratohyal sutured to the ventral hypohyal, the suture occupying less than half of the lateral border of the ventral hypohyal (Figs. 47c,d). In the doradids Hemidoras, Nemadoras, Oxydoras, and Tenellus, on the other hand, there is a long anterior process sutured to the ventral hypohyal, the suture occupying more than half of the lateral border of the ventral hypohyal (Figs. 47d,f). This character was coded as missing data for the auchenipterid Spinipterus.

175. Posterior portion of ventral hypohyal and anterior ceratohyal: 0 - connected via cartilage; 1 - connected via bony suture (CI 0.2, RI 0.5).

In the amphiliid Amphilius jacksoni, auchenipterids Ageneiosus and Tetranematichthys, and doradids Lithodoras, Oxydoras, and Rhinodoras the posterior portion of the ventral hypohyal and the anterior ceratohyal are connected via bony suture in medium and large-sized specimens (Figs. 46, 47d; Ferraris, 1898: \#G8; Walsh, 1990: \#10; Akama, 2004: \#83; Sousa, 2010: \#36). This character was coded as missing data for the doradids Rhinodoras thomersoni and Megalodoras, and the auchenipterid Spinipterus.

176. Interhyal: 0- present; 1 - absent (CI 0.333 , RI 0.667).

The interhyal is absent in the Amblycipitidae, Amphiliidae, Akysidae, Astroblepidae, Clariidae, Erethistidae, Mochokidae, Scoloplacidae, and Sisoridae (Mo, 1991: \#45; Britto, 2002: \#79; Vigliotta, 2008: \#49), being present in members of all other examined taxa (Fig. 47a). This character was coded as missing data for the auchenipterid Spinipterus.

177. Number of branchiostegal rays (ordered): 0 - four to six; 1 - seven to nine; 2 - ten to twenty (CI 0.2, RI 0.5).

The number of branchiostegal rays varies from three to twenty in catfishes (McAllister, 1968; Lundberg, 1970; Arratia, 2003a), although eight is the most common value. In the typical condition, one or two are articulated to the interceratohyal cartilage, four or five to the anterior ceratohyal and two or three to the posterior ceratohyal. Among the examined taxa, most species have seven to nine branchiostegal rays; however members of the Ariidae, Aspredinidae, Erethistidae, Sisoridae, mochokids Mochokiella, Mochokus niloticus, and Chiloglanis (Vigliotta, 2008: \#52), auchenipterids Centromochlus, Gelanoglanis, Glanidium and Tatia, and doradids Acanthodoras and some specimens of Platydoras armatulus have four to six (Sousa, 2010: \#39). The Bagridae, Nematogenyidae, Pangasiidae, Siluridae, and the auchenipterids Ageneiosus (A. inermis, A. polystictus, A. ucayalensis, A. valenciennesi, and A. vittatus) and Tetranematichthys have ten or more (Walsh, 1990: \#35). This character was coded as missing data for the auchenipterid Pseudotatia, Spinipterus, and as polymorphic $(0,1)$ for Platydoras armatulus.

\section{Brachial arches}

178. Pseudobranchia: 0- present; 1 - absent (CI 1.0, RI 1.0).

A pseudobranch is only present in the Diplomystidae and Nematogenyidae (Arratia, 1992: \#34), among examined taxa.

179. Accessory branchial lamellae on ceratobranchial (ordered): 0- absent; 1- restricted to branchial arch; 2distributed on branchial arch and filaments (CI 0.667, RI 0.966).

In the doradids Anduzedoras, Doras, Hassar, Hemidoras, Leptodoras, Nemadoras, Ossancora, Oxydoras, and Tenellus there are conspicuous accessory lamellae on the medial face of the ceratobranchials (best developed on first two branchial arches; Figs. 48g,h,k,l, 49; Higuchi, 1992: \#A49, \#A50). In addition, these lamellae are also extended onto the branchial filaments in Leptodoras (Fig. 49k-l; Higuchi, 1992: \#A51; Sabaj, 2002: \#15; Sabaj, 2005; Birindelli et al., 2008; Birindelli \& Sousa, 2010). In all other examined taxa, the accessory branchial lamellae are absent from ceratobranchials (Fig. 48a-f,i-j).

180. Accessory lamellae on epibranchials (unordered): 0absent; 1- similar to those of ceratobranchial; 2- developed as three large lamellae; 3 - developed as a thick lobe (CI 0.75, RI 0.963).

In the doradids Anduzedoras, Doras, Hassar, Hemidoras, Leptodoras, Nemadoras, Ossancora, and Tenellus, there are accessory lamellae on the epibranchials, similar to those on the ceratobranchial (Figs. 48k,l, 49). The doradid Oxydoras niger (congeners not observed) has three large lamellae on the epibranchials, distinct from the small lamellae of the ceratobranchial (Figs. 48g,h). The doradids Rhinodoras and Orinocodoras, on the other hand, have a thick lobe on the 
epibranchials (Figs. 48e,f). All other examined taxa lack accessory branchial lamellae on epibranchials (Fig. 48a-f,i-j). This character was coded as missing data for the doradid Oxydoras kneri.

181. Number of rows of gill rakers on first two branchial arches (ordered): 0- two; 1- one; 2- none (CI 0.2, RI 0.6).

Most examined taxa have only one row of gill-rakers on the first two branchial arches. However, the Ariidae, Cetopsidae, Diplomystidae, Siluridae (Lundberg, 1970; de Pinna, 1993: \#176; Britto, 2002: \#129; de Pinna et al., 2007: \#77), and the auchenipterids Ageneiosus, Asterophysus, Auchenipterichthys, Liosomadoras, Pseudauchenipterus, Tetranematichthys, Trachelyichthys, Trachelyopterichthys, and Trachycorystes (Britski, 1972: 24; Royero, 1999: \#113; Akama, 2004: \#85) have two rows of rakers on the first two branchial arches. On the other hand, members of the Aspredinidae, auchenipterid Gelanoglanis, doradids
Trachydoras, and some species of Leptodoras, including $L$. cataniai, L. juruensis, and L. myersi (Sabaj, 2005), have the first two branchial arches without gill rakers. This character was coded as missing data in the auchenipterids Pseudotatia and Spinipterus.

182. Number of rows of gill rakers on third and fourth branchial arches (ordered): 0- two; 1- one; 2- none (CI 0.182, RI 0.7).

Most examined taxa have only one row of gill rakers on the third and fourth branchial arches. However, the Ariidae, Cetopsidae, Diplomystidae, Siluridae (Lundberg, 1970; de Pinna, 1993: \#176; Britto, 2002: \#129; de Pinna et al., 2007: \#77), auchenipterids Ageneiosus, Asterophysus, Auchenipterichthys, Liosomadoras, Pseudauchenipterus, Tetranematichthys, Trachelyichthys, Trachelyopterichthys, and Trachycorystes (Britski, 1972: 24; Royero, 1999: \#113; Akama, 2004: \#85) have two rows of rakers on the third and fourth branchial arches. On the other hand, the Aspredinidae,

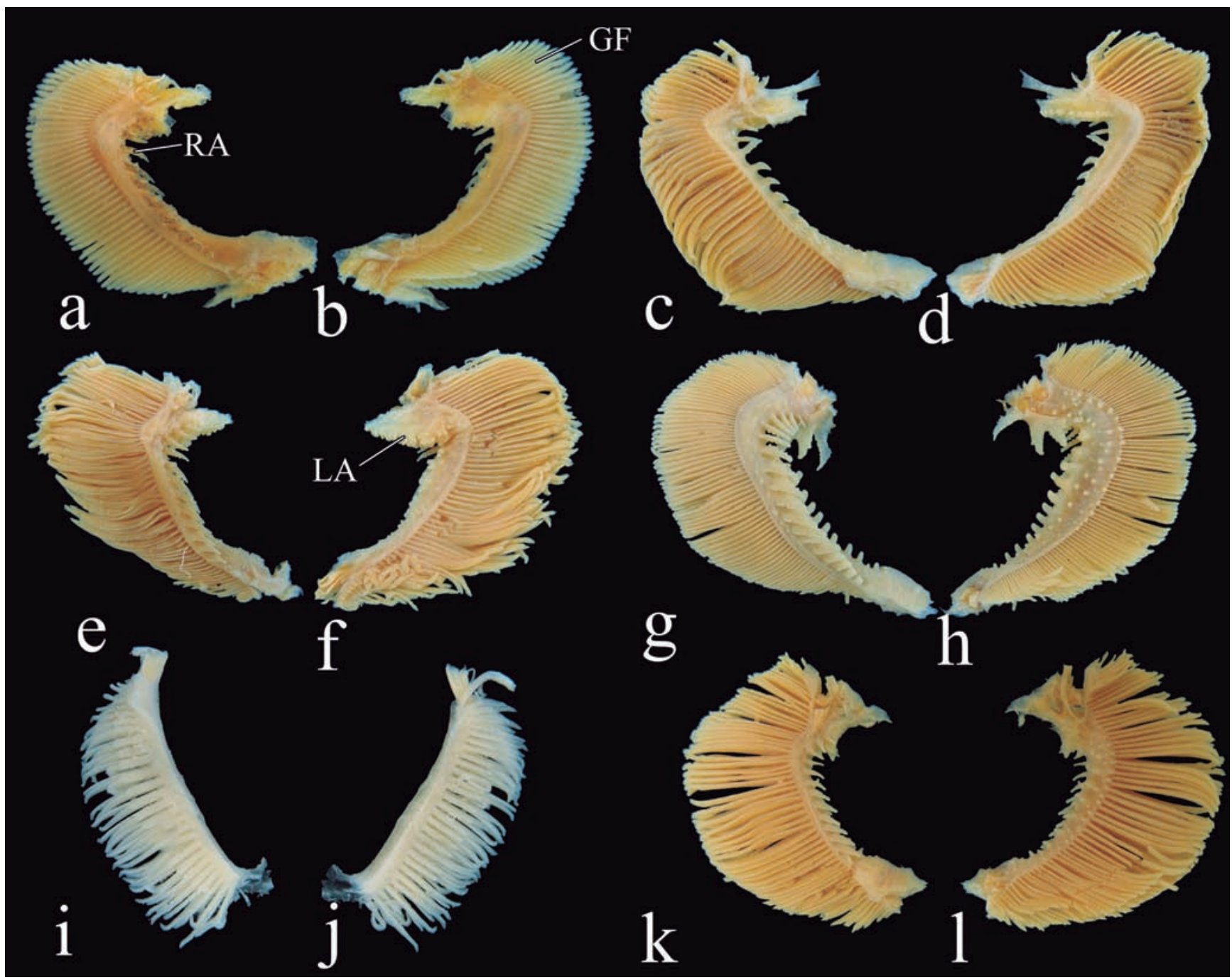

Fig. 48. First branchial arch in lateral (a,c,e,g,i,k) and medial (b,d,f,h,j,l) views of (a,b) Platydoras armatulus, MZUSP 94088, 135.4 mm SL; (c,d) Centrodoras brachiatus, MZUSP 103892, 205 mm SL; (e,f) Rhinodoras dorbignyi, MZUSP 36528, 141.6 mm SL; (g,h) Oxydoras niger, MZUSP 56162, 154.6 mm SL; (i,j) Trachydoras steindachneri, MZUSP 49526, 82.4 mm SL; (k,1) Ossancora eigenmanni, MZUSP 5646, 95.4 mm SL. GF gill filaments, LA branchial lamellae, RA gill-rakers. 
auchenipterid Gelanoglanis, and doradids Anduzedoras, Doras, Hassar, Leptodoras, and Trachydoras (Sabaj \& Birindelli, 2008; Birindelli et al., 2009; Birindelli \& Sousa, 2010), lack rakers on the third and fourth branchial arches. This character was coded as missing data in the auchenipterids Pseudotatia and Spinipterus.

183. Size of gill rakers (unordered): 0- rudimentary, length smaller than one-tenth of that of gill filament; 1- moderately sized, length between one-tenth and half of that of gill filament; 2- elongate, longer than half of gill filament (CI 0.667, RI 0.9).

Most catfishes have moderately-sized gill-rakers, length between one-tenth and one-half that of gill filament (Figs. 4849, 50a-b). However, the auchenipterids Asterophysus, Auchenipterichthys, Liosomadoras, Pseudauchenipterus, Trachelyichthys, Trachelyopterichthys, Trachelyopterus, and
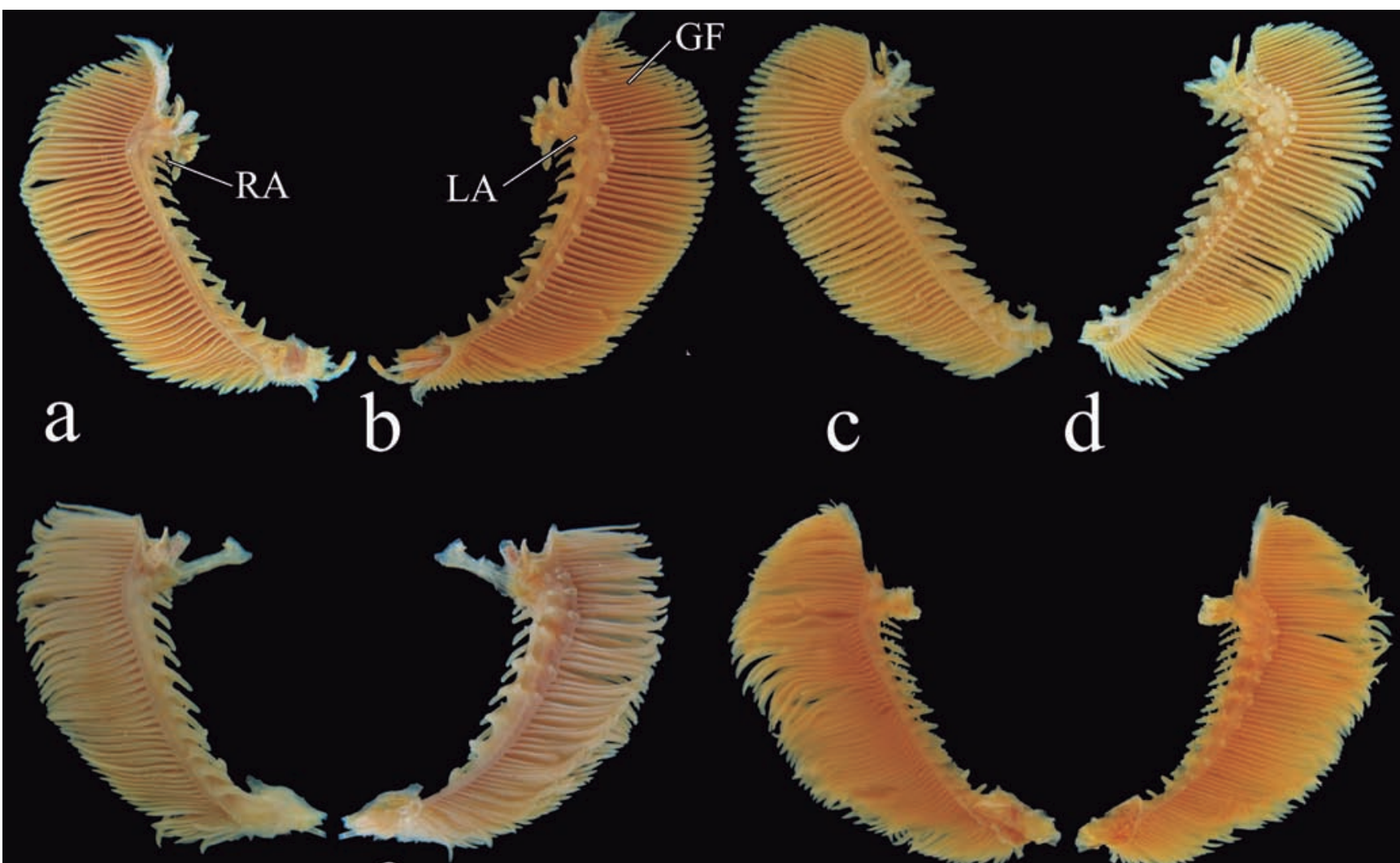

e
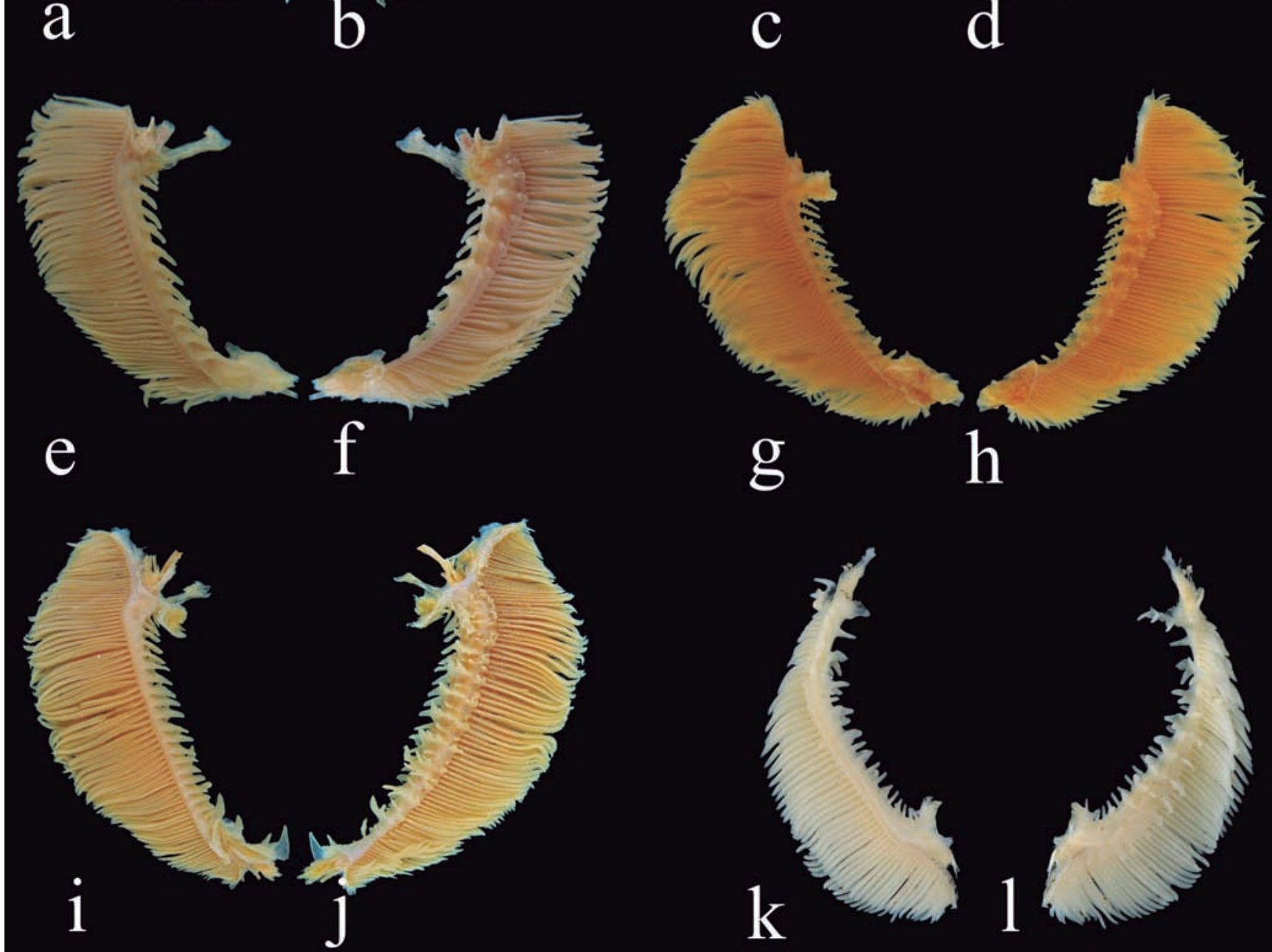

Fig. 49. First branchial arch in lateral and medial views, respectively, of (a,b) Hemidoras morrisi, MZUSP 23878, 161 mm SL; (c,d) Nemadoras elongatus, MZUSP 83211, 121.7 mm SL; (e,f) Tenellus leporhinus, MZUSP 95617, 136.5 mm SL; (g,h) Hassar affinis, 43605, 157 mm SL; (i,j) Anduzedoras oxyrhynchus, MZUSP 50838, 230 mm SL; (k,l) Leptodoras marki, MZUSP 103217, 83.2 mm SL. GF gill filaments, LA branchial lamellae, RA gill rakers. 
Trachycorystes, have rudimentary gill-rakers, shorter than onetenth of that of gill filament (Figs. 50c; Britski, 1972: 24; Ferraris, 1988: \#G4; Walsh, 1990: \#27; Akama, 2004: \#86). Royero (1999: \#111) and Akama (2004: \#84) reported the gill-rakers to be lacking in Trachelyichthys and Trachelyopterichthys, but specimens observed of these taxa do indeed have short gill rakers. Elongate gill rakers, longer than half the length of a gill filament, are present in the auchenipterids Auchenipterus, Epapterus, and Pseudepapterus (Fig. 50d; Britski, 1972: 24; Ferraris, 1988: \#G4; Walsh, 1990: \#27; Akama, 2004: \#86). This character was coded as inapplicable for the Aspredinidae, auchenipterid Gelanoglanis, and doradids Trachydoras, and Leptodoras juruensis, which lack gill-rakers; and as missing data for the auchenipterids Pseudotatia and Spinipterus.

184. Dorsal face of gill rakers: 0- straight, without spines; 1 - with spines (CI 0.5, RI 0.0).

Among all examined species, only the auchenipterids Tetranematichthys and Tocantinsia have gill-rakers with spines on the dorsal face (Fig. 50b; Royero, 1999: \#112). Although Higuchi (1992: \#A48) mentioned gill rakers with spines for the doradid Orinocodoras eigenmanni, and Royero (1999: \#112) for the auchenipterid Ageneiosus; these observations were not corroborated based on the specimens examined herein. This character was coded as inapplicable for the Aspredinidae, auchenipterid Gelanoglanis, and doradids Trachydoras and Leptodoras juruensis, which lack gill-rakers; and as missing data for the auchenipterid Pseudotatia and Spinipterus.

185. Base of gill-rakers: 0- relatively small, not distinctly larger than diameter of gill-rakers; 1- enlarged, distinctly larger than

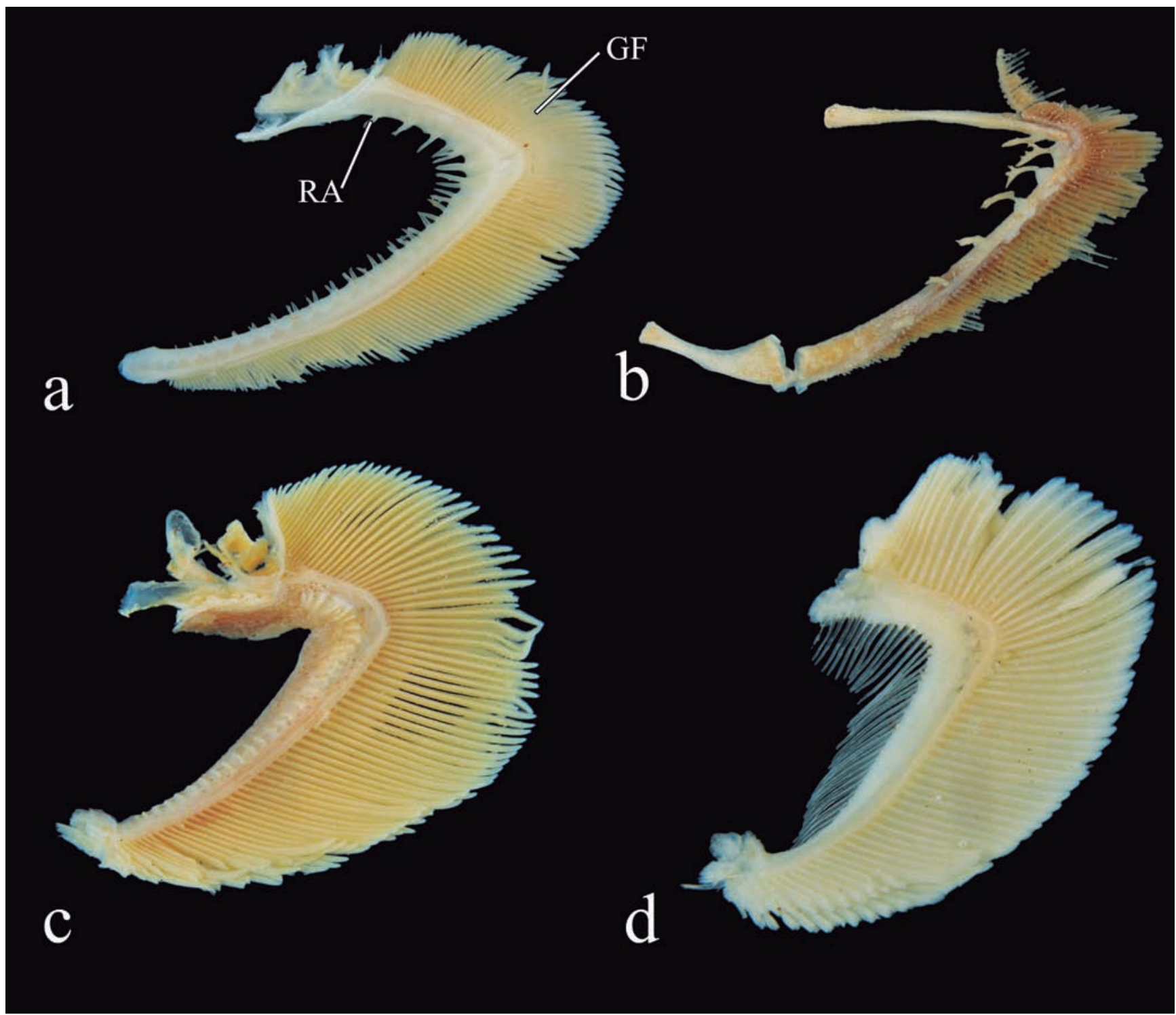

Fig. 50. First branchial arch in lateral view of (a) Ageneiosus inermis, MZUSP 101653, 202 mm SL; (b) Tocantinsia piresi, MZUSP 100031, 430 mm SL; (c) Trachycorystes trachycorystes, MZUSP 7381, 136.8 mm SL; (d) Auchenipterus nuchalis, MZUSP 101618, 152.9 mm SL. GF gill filaments, RA gill-rakers. 
diameter of gill-rakers (CI 0.5, RI 0.667).

The base of the gill-rakers of the Siluridae, and auchenipterids Ageneiosus and Tetranematichthys is enlarged and firmly attached to the branchial arches (Fig. 50a). This character was coded as inapplicable for the Aspredinidae, auchenipterid Gelanoglanis, and doradids Trachydoras and Leptodoras juruensis, which lack gill-rakers; and as missing data for the auchenipterids Pseudotatia and Spinipterus.

186. Number of gill-rakers on first branchial arch (unordered): 0- 15 or less; 1 - 16 to 25; 2- 30 or more (CI 0.4, RI 0.571).

Although most catfishes have fewer than 15 gill-rakers on the first branchial arch, the doradids Anadoras, Anduzedoras, Leptodoras (Sabaj, 2005; Birindelli et al., 2008; Sousa, 2010: \#40; Birindelli \& Sousa, 2011), and auchenipterids Pseudepapterus cucuhyensis and $P$. hasemani (Ferraris \& Vari, 2000) have 16 to 25. On the other hand, the Siluridae, auchenipterids Auchenipterus (Ferraris \& Vari, 1999), Epapterus (Vari \& Ferraris, 1998) and
Pseudepapterus gracilis (Ferraris \& Vari, 2000; Ferraris, 1988: \#G4) have more than 30 gill-rakers on the first branchial arch. This character was coded as inapplicable for the Aspredinidae, auchenipterid Gelanoglanis, and doradids Trachydoras and Leptodoras juruensis, which lack gillrakers; and as missing data for the auchenipterids Pseudotatia and Spinipterus.

187. Second and third basibranchials: 0 - moderate in size; 1 rudimentary (CI and RI inapplicable).

The auchenipterid Asterophysus has relatively rudimentary second and third basibranchials compared to all other catfish (Fig. 51; Ferraris, 1988: \#G6; Akama, 2004: \#81). This character was coded as missing data for the auchenipterid Spinipterus.

188. Length of ventral process of fourth basibranchial: 0short; 1- elongate (CI 1.0, RI 1.0).

In most catfishes, the fourth basibranchial has a short ventral process that extends from the branching of the

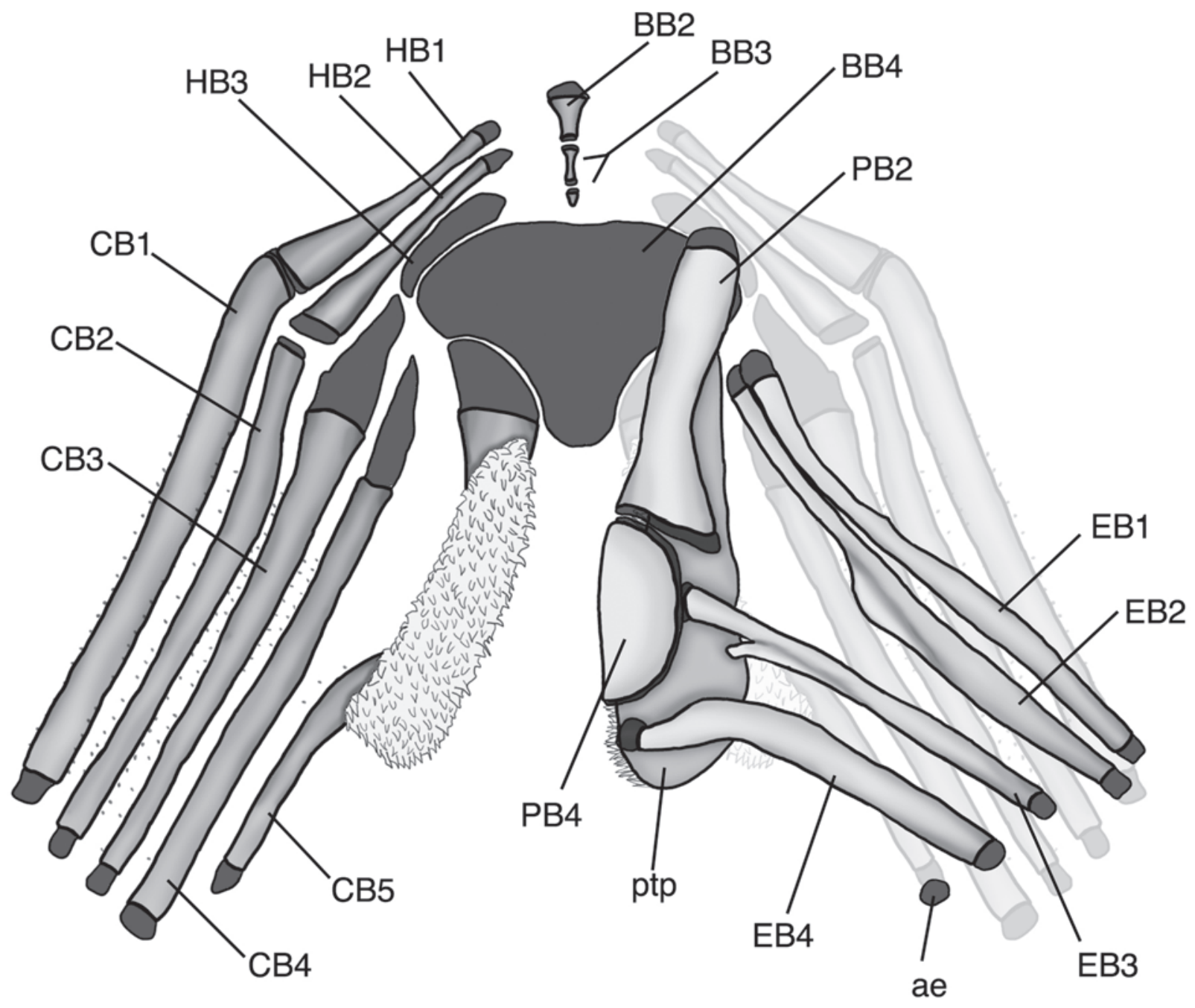

Fig. 51. Schematic drawing of the branchial arches in dorsal view of Asterophysus batrachus, based on INPA 24119, $127 \mathrm{~mm}$ SL. ae accessory element of certobranchial 4, BB basibranchial, CB ceratobranchial, HB hypobranchial, PB pharyngobranchial, ptp pharyngobranchial tooth plate. 
branchial arteries to the anterior tip of the fifth ceratobranchial. In the doradids Anduzedoras, Doras, Hassar, Hemidoras, Leptodoras, Nemadoras, Ossancora, Oxydoras, Tenellus, and Trachydoras, this process is elongate, extended posteriorly far beyond the anterior tip of the fifth ceratobranchial (Fig. 52). This character was coded as missing data for the auchenipterid Spinipterus.

189. Shape of tip of ventral process of fourth basibranchial: 0- simple; 1- trifid (CI 1.0, RI 1.0).

In the doradid Trachydoras the tip of the ventral process of the fourth basibranchial is trifid (Fig. 52b), whereas it is simple in all other examined taxa (Fig. 52a). This character was coded as missing data for the auchenipterid Spinipterus.

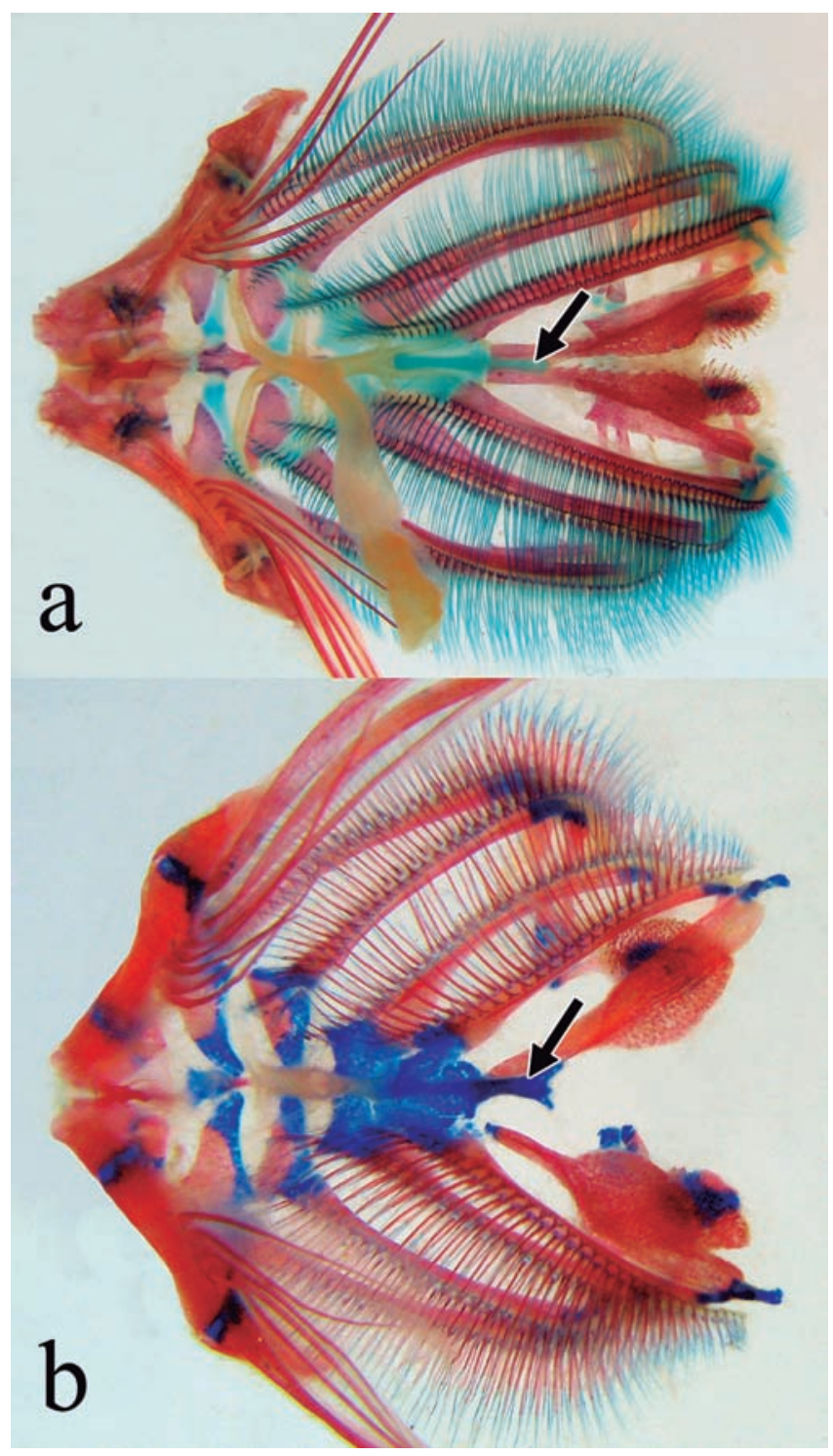

Fig. 52. Branchial arches of cleared and stained specimens in ventral view of (a) Doras phlyzakion, MZUSP 50836, $67.5 \mathrm{~mm}$ SL; (b) Trachydoras microstomus, MZUSP 57703, $76.6 \mathrm{~mm}$ SL. Arrows indicate posterior process of fourth basibranchial.
190. Accessory cartilage between third and fourth basibranchials: 0- absent; 1- present (CI 0.333, RI 0.875).

In all auchenipterids (except the Centromochlinae and Asterophysus) there is an accessory cartilage between the third and fourth basibranchials (Ferraris, 1988: \#G2; Akama, 2004: \#79). The same condition is present in the Akysidae and Sisoridae (de Pinna, 1993: \#184; de Pinna, 1996: \#41; Britto, 2002: \#90). The accessory cartilage between the third and fourth basibranchials is absent in other examined taxa. This character was coded as missing data for the auchenipterids Pseudotatia and Spinipterus.

191. Shape of first hypobranchial: 0- discoid; 1 - cylindrical (CI 0.167, RI 0.783).

The first hypobranchial is cylindrical in the Aspredinidae, Erethistidae (de Pinna, 1996: figs. 16-20), auchenipterids Ageneiosus, Asterophysus, Auchenipterichthys, Centromochlus, Gelanoglanis, Liosomadoras, Pseudauchenipterus, Pseudotatia, Tatia, Tetranematichthys, Tocantinsia, Trachelyichthys, Trachelyopterichthys, Trachelyopterus and Trachycorystes, and doradids Anduzedoras, and Leptodoras (Figs. 51, 53; Higuchi, 1992: \#A46; Birindelli et al., 2008). In some of those taxa (e.g., Asterophysus, Gelanoglanis, and Leptodoras) the second basibranchial is also cylindrical (Fig. 51). In other catfishes, the first two hypobranchials are discoid (Fig. 54). This character was coded as missing data for the auchenipterid Spinipterus.

192. Second hypobranchial: 0 - ossified; 1 - cartilaginous (CI 0.333, RI 0.0).

The second hypobranchial is ossified in most catfishes (Figs. 51-54). However, the Aspredinidae, Erethistidae, and Nematogenyidae have a cartilaginous second hypobranchial (de Pinna, 1996: \#38; Britto, 2002: \#92; de Pinna et al., 2007: \#38). This character was coded as missing data for the auchenipterid Spinipterus.

193. Anterior limb of fifth ceratobranchial: 0 - short, length much smaller than length of tooth patch; 1- elongate, length approximately equal to length of tooth patch (CI 1.0, RI 1.0).

In most catfishes, the anterior limb of the fifth ceratobranchial is much smaller that the associated toothplate (Fig. 55a). However, in the doradids Anduzedoras, Doras, Hassar, Hemidoras, Leptodoras, Nemadoras, Ossancora, Oxydoras, Tenellus, and Trachydoras, the anterior limb of the fifth ceratobranchial is extremely elongate, with length approximately equal to length of tooth patch (Fig. 55b-c; Higuchi, 1992: \#60). This character was coded as missing data for the auchenipterid Spinipterus.

194. Teeth on fifth ceratobranchial: 0- numerous, occupying most of middle portion of fifth ceratobranchial; 1- few in number and restricted to medial margin (CI 1.0, RI 1.0).

In the doradid Leptodoras, the teeth of the fifth ceratobranchial are few in number and restricted to a single 
row on the medial margin of the bone (Fig. 55c; Birindelli et al., 2008: fig. 10). All other examined taxa have numerous teeth occupying most of middle portion of fifth ceratobranchial (Fig. 5a-b). This character was coded as missing data for the auchenipterid Spinipterus.

195. Shape of first epibranchial: 0- roughly cylindrical, uniform; 1- with medial end enlarged, distinctly larger than lateral end (CI 1.0, RI 1.0).

In most catfishes, the first epibranchial is roughly cylindrical (Figs. 51, 53-54). However, in the auchenipterids Ageneiosus and Tetranematichthys the medial end of the first epibranchial is distinctly enlarged, distinctly larger than lateral end (Ferraris, 1988: \#G3; Walsh, 1990: \#8; Royero, 1999: \#109; Akama, 2004: \#77). This character was coded as missing data for the auchenipterid Spinipterus.

196. Accessory element of fourth ceratobranchial: 0- present; 1- absent (CI 0.5, RI 0.0).

The accessory element of fourth ceratobranchial is present as a small cartilage in most catfishes. However, in the Aspredinidae and Erethistidae it is absent (de Pinna, 1993: \#139; Britto, 2002: \#113). This element was uncorrectly identified as the fifth epibranchial until recently (Carvalho et al., 2013). This character was coded as missing data for the auchenipterid Spinipterus.

197. First pharyngobranchial: 0- present; 1 - absent (CI 0.25, RI0.0).

Among examined species, the first pharyngobranchial is present only in the Ariidae (except Galeichthys, Marceniuk et al., 2012:\#182), Claroteidae, Diplomystidae, and Pangasiidae (Lundberg, 1970; Mo, 1991: \#47; de Pinna, 1993: \#140; Britto, 2002: \#116; de Pinna et al., 2007: \#75; Marceniuk et al., 2012: \#182). This character was coded as missing data for the auchenipterid Spinipterus.

198. Second pharyngobranchial: $0-$ present; $1-$ absent (CI 0.5 , RI 0.0).

Among examined species, the second pharyngobranchial

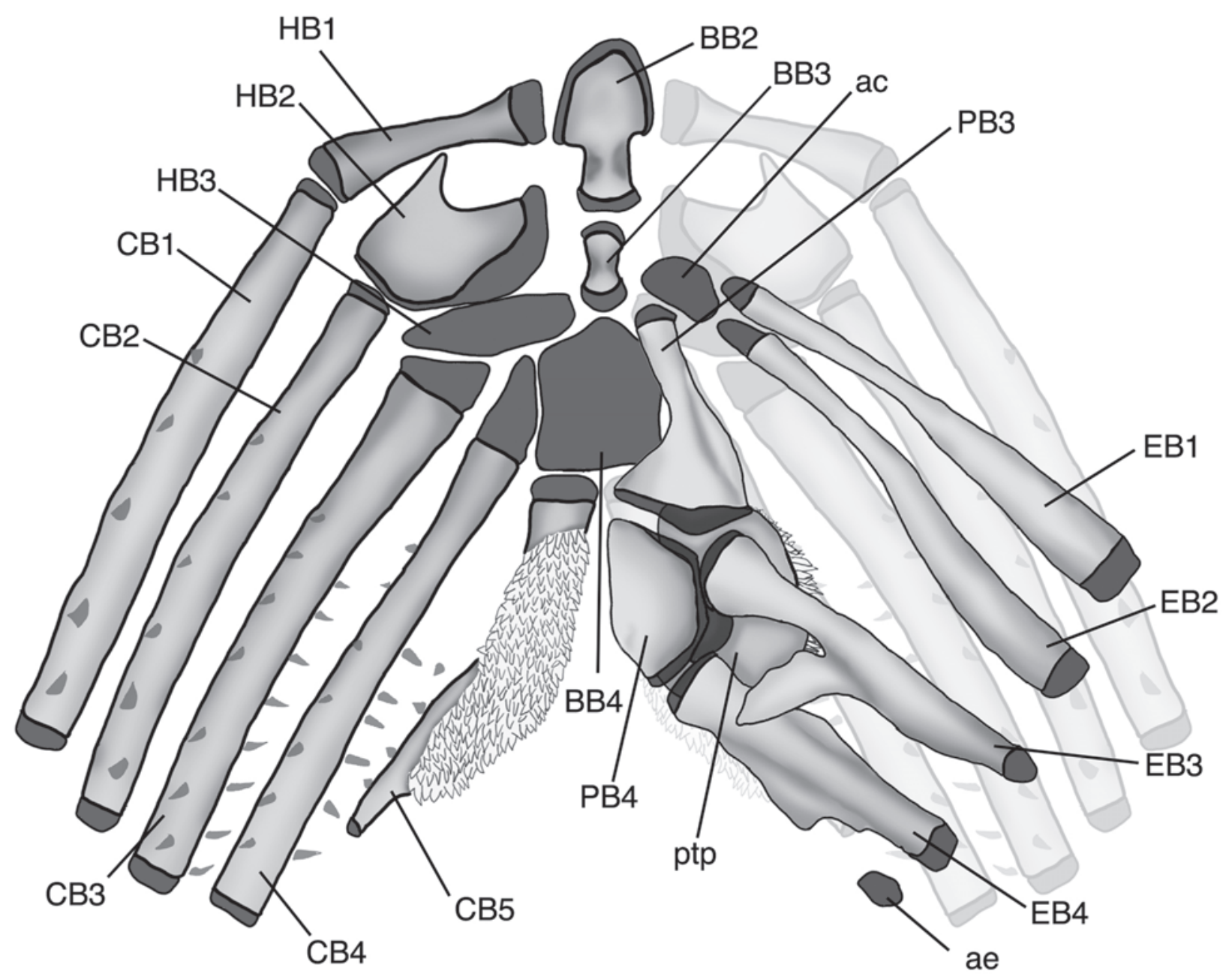

Fig. 53. Schematic drawing of the branchial arches in dorsal view of Glanidium melanopterum, based on MZUSP 51043, 107.9 mm SL. ac pharyngobranchial accessory cartilage, ae accessory element of ceratobranchial 4, BB basibranchial, CB ceratobranchial, HB hypobranchial, PB pharyngobranchial, ptp pharyngobranchial tooth plate. 
is present only in the Diplomystidae (Arratia, 1987) and Pangasiidae (de Pinna, 1993: \#185; Britto, 2002: \#118; de Pinna et al., 2007: \#76).

199. Shape of pharyngobranchial tooth plate (ordered): 0 rounded, length slightly greater than width; 1- elongated, length approximately twice width; 2- extremely elongate, length approximately three times width (CI 0.667, RI 0.969).

The pharyngobranchial toothplate is rounded, with its length slightly greater than its width, in most catfishes (Figs. 53-54). However, in the doradids Anduzedoras, Doras, Hassar, Hemidoras, Leptodoras, Nemadoras, Ossancora, Oxydoras, Tenellus, and Trachydoras, the pharyngobranchial tooth plate is elongate, with its length approximately twice its width. In the auchenipterid Asterophysus it is extremely elongate, with its length approximately three times its width (Fig. 51; Britski, 1972: \#25; Ferraris, 1988: \#G5; Akama, 2004: \#80). This character was coded as missing data for the auchenipterid Spinipterus.

\section{Axial skeleton}

200. Lateral expansion of first vertebra: 0 - absent; 1 - present (CI 1.0, RI 1.0).

In the doradids Orinocodoras and Rhinodoras, the first vertebra is laterally expanded, which results in a somewhat trapezoidal shape in ventral view (Fig. 36b; Higuchi, 1992: \#63). In other examined taxa, lateral expansions are absent from the first vertebra (Fig. 36a,d, 35). This character was coded as missing data for the auchenipterid Spinipterus.

201. Bony capsule on anterior vertebrae: 0 - absent; 1 - present (CI 1.0, RI 1.0).

The doradids Anduzedoras and Leptodoras have a pair of conjoined bony capsules on the ventral surface of the anterior vertebrae (Fig. 36c; Higuchi, 1992: \#64; Birindelli et al., 2008; Birindelli \& Sousa, 2010), absent in other examined taxa (Figs. 35, 36a-b,d). This character was coded as missing data for the auchenipterid Spinipterus.

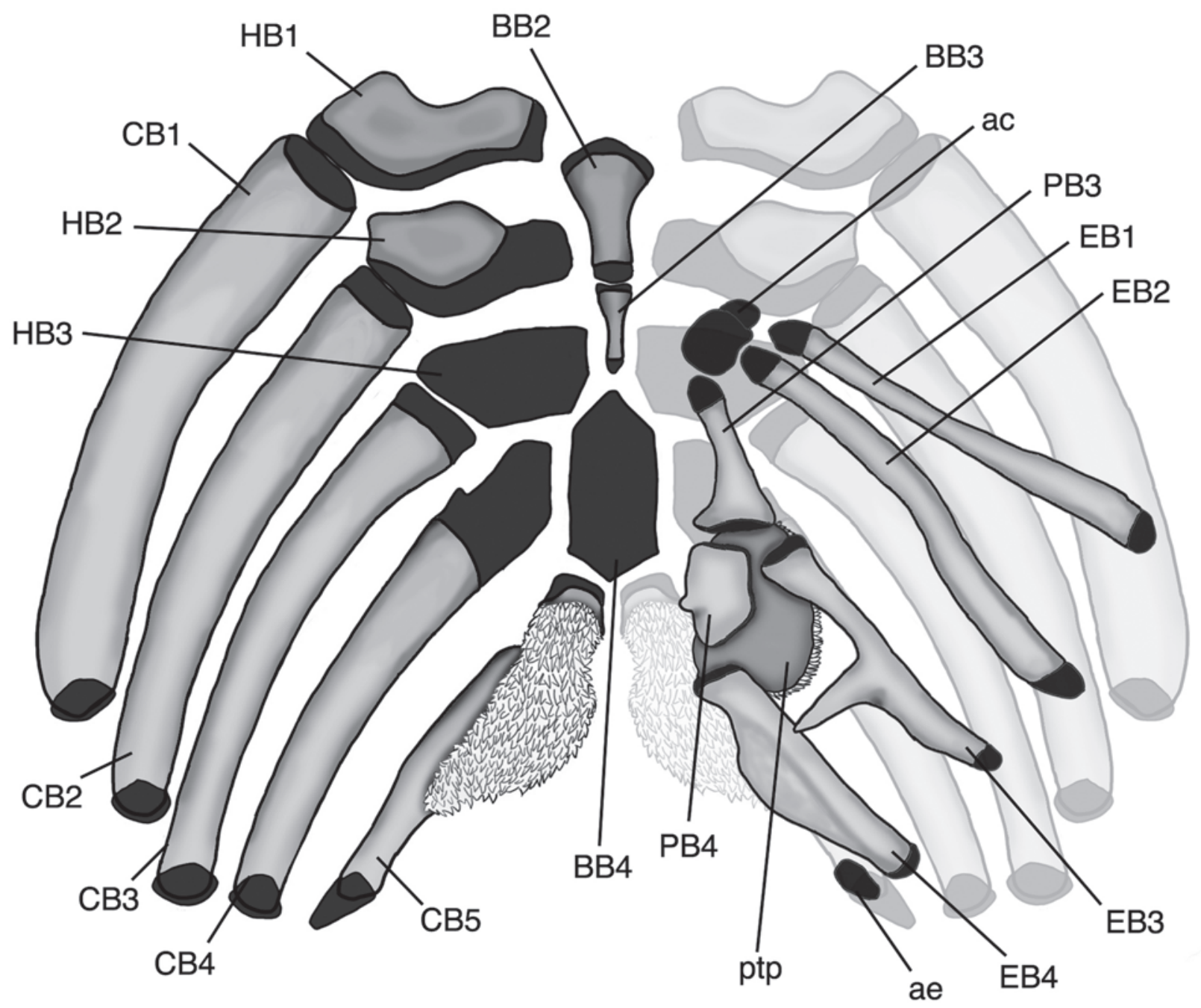

Fig. 54. Schematic drawing of the branchial arches in dorsal view of Wertheimeria maculata, based on MZUSP 93658,192 mm SL. ac pharyngobranchial accessory cartilage, ae accessory element of ceratobranchial 4, BB basibranchial, CB ceratobranchial, HB hypobranchial, PB pharyngobranchial, ptp pharyngobranchial tooth plate. 
202. Shape of bony capsules on anterior vertebrae (unordered): 0- small, with large posterior opening; 1- small, with small posterior opening; 2- large, with small posterior opening (CI 1.0, RI 1.0).

As discussed by Birindelli et al. (2008) and Birindelli \& Sousa (2010), the morphology of the bony capsules varies in the species of the doradids Anduzedoras and Leptodoras, with Anduzedoras having small subtriangular bony capsules with small posterior opening, Leptodoras marki and L. oyakawai having small cup-like bony capsules with large posterior opening, and the other species of Leptodoras having large rounded bony capsules with small posterior opening. This character was coded as inapplicable for all other examined taxa.

203. Transformator process of tripus: 0 - curved ventrally; 1 straight (CI 1.0, RI 1.0).

The transformator process of the tripus is curved ventrally and loosely attached to the gas bladder in most catfishes (Figs. 35b,d,f; Arratia, 1987; Lechner \& Ladich, 2008). However, in the species of the Auchenipteridae and Doradidae, the transformator process of the tripus is straight and firmly attached to the gas bladder (Figs. 35h, 36; Bridge \& Haddon, 1890: 160, 233 [referred to as crescentic process]; Britski, 1972: 19; Ferraris, 1988: \#V2; Royero, 1999: \#73; Akama, 2004: \#69). This character was coded as missing data for the auchenipterid Spinipterus.

204. Size of os suspensorium: 0- moderate; 1 - reduced (CI 1.0, RI 1.0).

The os suspensorium is moderate in size and firmly attached to the parapophysis of the fourth vertebra in most catfishes (Figs. 35b,d,f; Chardon et al., 2003). However, in the species of the Auchenipteridae and Doradidae, the os suspensorium is reduced to a nodule that is loosely connected to the parapophysis of the fourth vertebra (Figs. 35h, 36; Ferraris, 1988: \#V4; de Pinna, 1993: \#191; Royero, 1999: \#70; Britto, 2002: \#213; Akama, 2004: \#70).

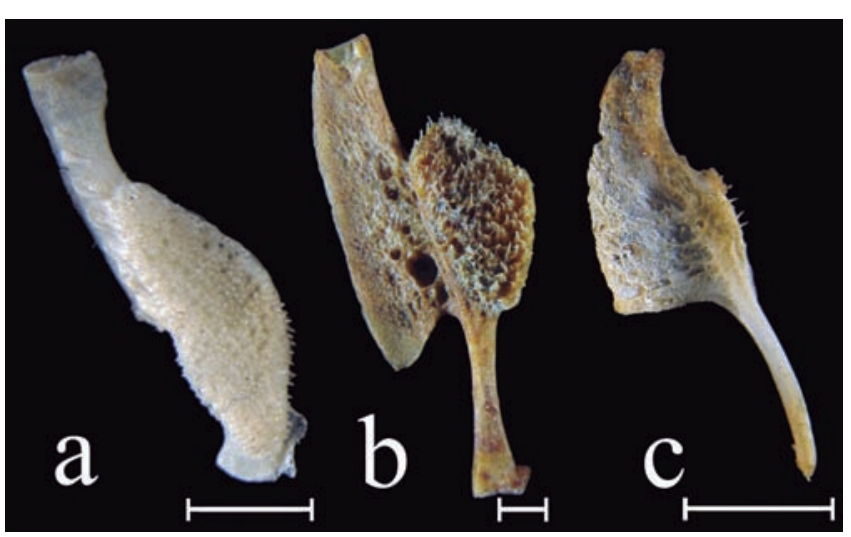

Fig. 55. Fifth ceratobranchial in dorsal view of (a) Kalyptodoras bahiensis, MZUSP 87841, 233 mm SL; (b) Oxydoras niger, MZUSP 91654, 550 mm SL; (c) Leptodoras juruensis, MZUSP 104532, 227 mm SL. Scale bars equal 5 mm.
205. Shape of anterior ramus of parapophysis of fourth vertebra (=Müllerian ramus) (unordered): 0- distally truncate, sutured to transcapular process; 1 - distally pointed, free from transcapular process; 2- modified with long thin base and distal flexible disc, latter connected to ventral face of gas bladder; 3- modified with short thin base and distal flexible disc, latter connected to dorsal face of gas bladder (CI 0.6, RI 0.882).

In most catfishes, the anterior ramus of the parapophysis of the fourth vertebra is truncated distally and sutured to the transcapular process (Fig. 35b; Bridge \& Haddon, 1892; Chardon, 1968). However, this attachment is lost, and the ramus becomes flexible (= Müllerian ramus) and associated with a modified muscle (= protractor muscle of the Müllerian ramus) in some catfishes. This modified set of structures forms the elastic spring apparatus as initially described by Müller (1842a, 1842b) for the auchenipterid Auchenipterus, the doradid Doras, the mochokid Synodontis and the malapterurid Malapterurus, later described for the pangasiid Pangasius by Bridge \& Haddon (1892), and finally for members of the Ariidae by Tavolga (1962). The elastic spring apparatus functions to produce sounds: contraction of the modified muscle pulls the elastic spring forward, extending the gas bladder, and its relaxation allows for elastic recoil, quickly restoring the gas bladder to its normal position (Fine \& Ladich, 2003). Repeated contractions of the modified muscle cause the gas bladder to vibrate, and the rapid compression and extension of the gas bladder radiates tonal sounds with fundamental frequency and harmonics (Fine \& Ladich, 2003).

In the Ariidae (except Galeichthys), the Müllerian ramus is largely unmodified, except for its freedom from the transcapular process and distal point (Fig. 35d; Tavolga, 1962; Marceniuk \& Birindelli, 2010). In the species of Mochokidae, the Müllerian ramus is modified with a long thin base and rounded distal disc, the latter attached to the ventral face of the gas bladder (Fig. 35f; Vigliotta, 2008; Ladich, 2001). In the species of Malapteruridae and Pangasiidae, the Müllerian ramus is similar to the one present in mochokids, although it is more rectangular and elongate than disc-like (state 2). In the species of Auchenipteridae and Doradidae, the Müllerian ramus is also greatly modified with a thin short base and rounded distal disc, the latter attached to the dorsal face of the gas bladder (Fig. 35h; Bridge \& Haddon, 1892; Regan, 1911; Alexander, 1965: 110; Chardon, 1968; Britski, 1972: 20; Curran, 1989: \#17; Royero, 1999:\#67,\#71; Akama, 2004:\#66,\#76). This character was coded as missing data for the auchenipterid Spinipterus.

206. Shape of disc of Müllerian ramus (unordered): 0- rounded and shallow; 1- shaped as a cone, with posterior apex; 2compact, reduced in size (CI 0.667, RI 0.967).

In all species of Auchenipteridae (except Ageneiosus and Centromochlus heckelii), Doradidae (except Oxydoras, Physopyxis and fimbriate-barbel doradids) and Mochokidae, the disc of the Müllerian ramus is rounded and shallow. However, in the doradids Anduzedoras, Doras, Hassar, Hemidoras, Lepodoras, Nemadoras, Ossancora, Tenellus, 
and Trachydoras (Eigenmann, 1925: 297; Higuchi, 1992: \#67) and the auchenipterid Centromochlus heckelii (Britski, 1972: 20; Ferraris, 1988: \#V8; Soares-Porto, 1996: \#16; Royero, 1999: \#67; Akama, 2004: \#68), the disc of the Müllerian ramus is shaped as a cone, posteriorly protruded against the wall of the bladder causing it to become indented (Fig. 36c). In the doradid Physopyxis (Sousa, 2010: \#46) and in large-sized species of the auchenipterid Ageneiosus (including A. inermis) the disc of the Müllerian ramus is compact, reduced in size (Britski, 1972: 20; Ferraris, 1988: \#V3; Walsh, 1990: \#23; Higuchi, 1992: \#A52; Royero, 1999: \#74; Akama, 2004: \#67). This character was coded as inapplicable for all taxa that lack the disc of the Müllerian ramus (i.e., all examined species except Auchenipteridae, Doradidae, and Mochokidae); and as missing data for the auchenipterid Spinipterus.

207. Protractor muscle of Müllerian ramus: 0- absent; 1present (CI 0.25, RI 0.75).

The protractor muscle of the Müllerian ramus is present in the Ariidae, Auchenipteridae, Doradidae, Malapteruridae, Mochokidae, and Pangasiidae (Fig. 56a-d; Müller, 1842a, 1842b; Bridge \& Haddon, 1892; Alexander, 1965; Chardon, 1968; Ferraris, 1988: \#V6; Diogo, 2004: \#256; Vigliotta, 2008: \#76; Marceniuk et al., 2012); it is absent in all other examined taxa (Fig. 56e-f). This character was coded as missing data for the auchenipterid Spinipterus.

208. Origin and insertion of protractor muscle of Müllerian ramus (unordered): 0- origin on medial portion of posterior surface of cranium, and insertion on disc of Müllerian ramus; 1- origin on posterior nuchal plate and insertion on base of Müllerian ramus; 2- origin on lateral portion of posterior cranium, and insertion on entire Müllerian ramus (CI 1.0, RI 1.0).

In the species of Auchenipteridae and Doradidae, the protractor muscle of the Müllerian ramus originates in a bony, posteriorly direct pocket formed by internal faces of parietalsupraoccipital, exoccipital, supraneurals, epiotic and anterior nuchal plate, and its insertion is restricted to the disc of the Müllerian ramus (Figs. 56a,b; Birindelli et al., 2009). In the Mochokidae, the protractor muscle of the Müllerian ramus originates on the posterior nuchal plate and inserts on the base of the Müllerian ramus (Fig. 56c; Taverne \& AloulouTriki, 1976; Ladich, 2001). In the Ariidae (except Galeichthys), Malapteruridae and Pangasiidae, it originates on the lateral portion of the posterior cranium (including the epiotic process in most ariids), and inserts on the entire Müllerian ramus (Fig. 56d; Tavolga, 1962; Marceniuk \& Birindelli, 2010; Marceniuk et al., 2012: \#229).

The nerve associated with the protractor muscle present in the Doradoidea belongs to the occipital-spinal plexus. The catfish skull usually has four nerve openings posteriorly: an anterior one for nerve IX (glossopharyngeal), a large one, posterior to the first exit, and anterior to the transcapular process, for nerve X (vague) (Arratia, 1987: 21; Freihofer, 1978: fig. 26), and two smaller ones posteriorly (posterior to the transcapular process). From the ventralmost of the two smaller exits, a nerve goes through, reaching directly the protractor muscle of the Müllerian ramus. The nerves that exit the cranium through openings located posterior to the transcapular process are the XI or XII nerve (Kesteven, 1943: 107, fig. 50), or the occipital-spinal plexus (Freihofer, 1963: 90, fig. 13). Either way, those are spinal nerves, which are also responsible for epaxial muscles (Allis, 1903: 220). These observations corroborate the hypothesis that the protractor muscles correspond to a modified part of the epaxial musculature (Tavolga, 1962). Alternatively, Royero (1999) considered the protractor muscles to be modifications of the supracarinalis anterior muscle, which is not present in the Auchenipteridae and Doradidae.

This character was coded as inapplicable for all taxa that lack the protractor muscle of the Müllerian ramus (i.e., Amphiliidae, ariid Galeichthys, Aspredinidae, Claroteidae, Diplomystidae, Erethistidae, Heptapteridae, Ictaluridae, Nematogenyidae, Pimelodidae, Pseudopimelodidae, Siluridae, and Sisoridae); and as missing data for the auchenipterid Spinipterus.

209. Number of sections of protractor muscle of Müllerian ramus: 0 - one; 1 - two (CI 0.5, RI 0.0).

The protractor muscle of the Müllerian ramus of most examined species of the Auchenipteridae and Doradidae is composed of a single section. However, in the auchenipterids Ageneiosus (A. atronasus and A. brevis) and Centromochlus (C. heckelii), the protractor muscle is divided into two sections (Fig. 57; Diogo, 2004: \#155; Parmentier \& Diogo, 2006: 54). This subdivision is somewhat difficult to visualize, so it is possible that it may also be present in other taxa. This character was coded as missing data for the auchenipterids Gelanoglanis, Pseudotatia, and Spinipterus. This character was coded as inapplicable for all taxa that lack the protractor muscle of the Müllerian ramus.

210. Posterior ramus of parapophysis of fourth vertebra: 0present; 1- absent (CI 1.0, RI 1.0).

Most catfishes have the parapophysis of the fourth vertebra with anterior and posterior rami (Fig. 35b,d,f). However, the posterior ramus of the parapophysis of the fourth vertebra is absent in the species of Auchenipteridae and Doradidae (Figs. 35h, 36; Regan, 1911; Vigliotta, 2008: \#79). This character was coded as innaplicable for the auchenipterid Spinipterus.

211. Size of parapophysis of fifth vertebra (ordered): 0 - reduced in size or, rarely, absent; 1- moderate in size, similar to those of subsequent vertebrae; 2 - relatively large, distinctly larger that those of subsequent vertebrae (CI 0.4, RI 0.875).

Most catfishes have the parapophysis of the fifth vertebra moderate in size, similar to those of subsequent vertebrae. In the Sisoroidea, Aspredinidae, and the mochokid Chiloglanis, the parapophysis of the fifth vertebra is relatively large, distinctly larger than those of the subsequent vertebrae (de 
Pinna, 1996: \#57, \#62; Britto, 2002: \#231; Diogo, 2004: \#138). The parapophysis of the fifth vertebra in doradids (except Leptodoras juruensis) and auchenipterids (except Gelanoglanis) is reduced in size, or occasionally [or rarely] absent (Figs. 35g,h, 36; Bridge \& Haddon, 1892: 230; Regan, 1911; Alexander, 1965: 111; Vigliotta, 2008: \#80). In specimens of Auchenipteridae and Doradidae, the parapophysis may be present on one side of a specimen, but absent on the other. In
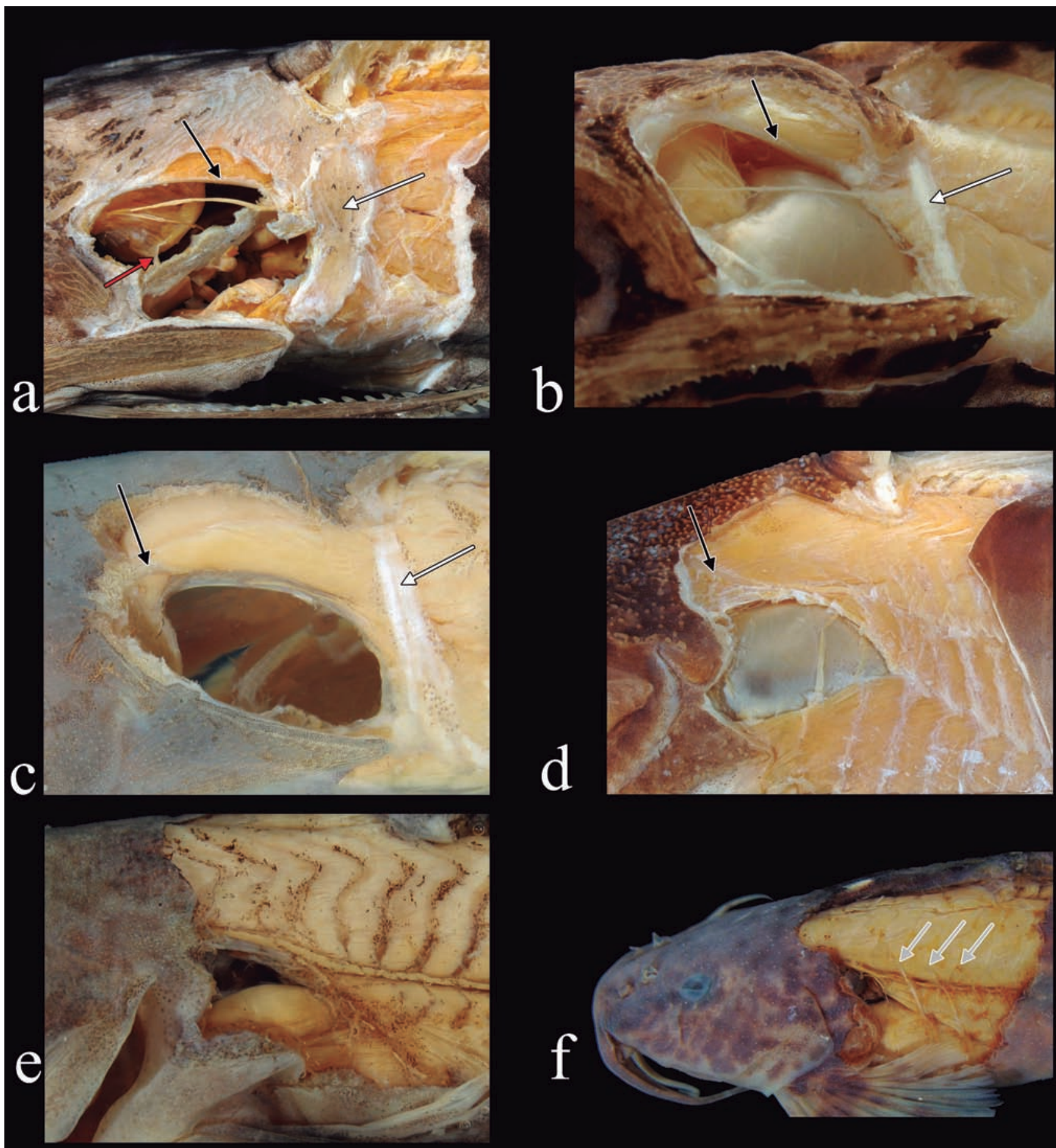

Fig. 56. Tympanic area in lateral view of (a) Wertheimeria maculata, MZUSP 93658, 186 mm SL; (b) Liosomadoras oncinus, MZUSP 93497, 74.8 mm SL; (c) Synodontis schall, MZUSP 84468, 76 mm SL; (d) Sciades herzbergii, MZUSP 48636, 72.4 mm SL; (e) Diplomystes mesembrinus, MZUSP 62595, 99.2 mm SL; (f) Amphilius jacksoni, MZUSP 48636, 72.4 mm SL. White arrows (a,b,c) indicate infranuchal ligament, black arrows (a,b,c,d) indicate epiotic-process ligament, red arrow (a) indicates the ligament between Müllerian ramus and lateral line, grey arrows (f) indicate ligament between ribs and muscle fascia. 
the examined species of the auchenipterid Gelanoglanis and doradid Leptodoras juruensis, the parapophysis of the fifth vertebra is moderate in size, similar to those of subsequent vertebrae (Fig. 36c). This character was coded as missing data for the auchenipterid Spinipterus.

212. Ligament between Müllerian ramus and lateral line: 0absent; 1-present (CI 1.0, RI 1.0).

A ligament between the Müllerian ramus and the lateral line is present in all species of Doradidae (Fig. 56a). This feature was reported for Pterodoras granulosus by Sörensen (1892: 124) and Royero (1999), and for Platydoras by Ladich (2001: 299). According to Sörensen (1892: 124), this ligament helps to propagate the sound produced by vibrations of the Müllerian ramus to the midlateral scute row. The Müllerian ramus is not connected to the lateral line in other examined taxa (Fig. 56b). This character was coded as missing data for the auchenipterid Spinipterus.

213. Infranuchal ligament (ordered): 0- absent; 1 - not ossified; 2- ossified (CI 1.0, RI 1.0).

In all examined specimens of Auchenipteridae and the mochokid Synodontis (other mochokids not examined for this character) there is an unossified ligament that extends between the posterior nuchal plate and the first rib, the infranuchal ligament (Figs. 56b,c). In the same location in the Doradidae, there is an ossification sutured dorsally to the posterior nuchal plate and ventrally to the first rib, the infranuchal scute (Fig. 56a; Ferraris, 1988: \#D6; Royero, 1999: \#68, \#104; Akama, 2004: \#75). As discussed by Ferraris (1988), the infranuchal scute is homologous to the ligament present in auchenipterids and mochokids, and it is formed by the ossification of both the ligament between the posterior nuchal plate and first rib and the adjacent portion of the lateral line. Royero (1999: \#68) and Akama (2004: \#75) considered the infranuchal ligament to be absent in the auchenipterids Ageneiosus and Tetranematichthys, but members of those taxa observed herein have that ligament.

Ferraris (1988: 45) mentioned that similar (and possibly

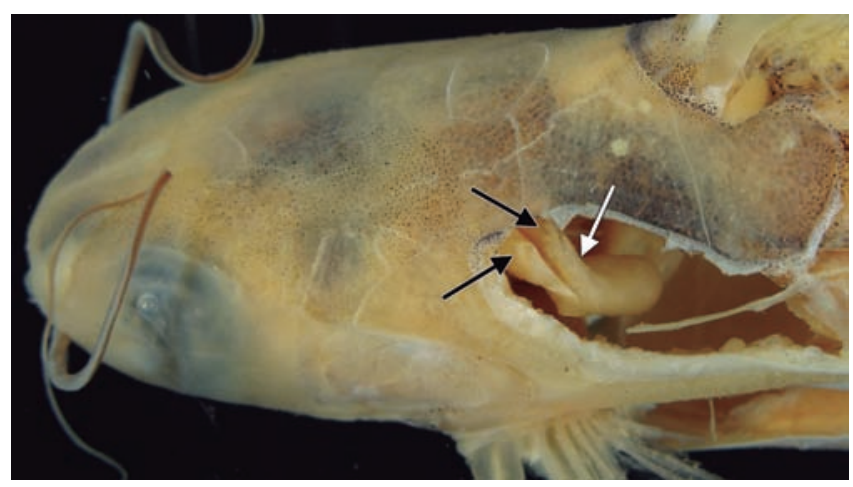

Fig. 57. Head and tympanic area in lateral view of Centromochlus heckelii, MZUSP 49529, 80.5 mm SL. White arrow indicates Müllerian ramus, black arrows indicate sections of the protractor muscle of the Müllerian ramus. homologous) ligaments are present in other catfishes (i.e., species of Amphiliidae and Sisoridae). However, based on the available specimens, in the Amphiliidae there are ligaments between the anterior ribs and the fascia of the epaxial muscle (Fig. 56f), whereas in the Sisoridae, no ligament was observed, and the entire tympanic area is modified, including ribs completely covered thick muscle layers.

Bailey \& Baskin (1976: 4) described a bone between the posterior nuchal plate and first rib, the lateral bone (or connecting bone of Armbruster, 2004: 32), present in the Scoloplacidae, Astroblepidae, and Loricariidae (see also Schaefer, 1990: 193, fig. 18B). In the examined specimens of Callichthyidae, there is an unossified ligament between the posterior nuchal plate and the first rib likely homologous to the lateral bone, although similar to the one observed in auchenipterids and mochokids. Nevertheless, the lateral bone of loricariids is distinct from the ossified infranuchal ligament of doradids by being covered by dermal bony plates (vs. exposed), and not associated to the lateral line canal (vs. associated). The infranuchal ligament is considered not homologous to the lateral bone (Britto, 2002: \#243).

This character was coded as missing data for all species of Mochokidae (except Synodontis).

214. Ligament between second rib and posterior nuchal plate: 0 - absent; 1- present (CI and RI inapplicable).

In the examined specimens of the mochokid Synodontis there is a ligament between the second rib and the posterior nuchal plate (Fig. 56c). The only other examined specimen with that ligament was a single auchenipterid specimen tentatively identified as Tatia cf. aulopygia (MZUSP 99309, $90 \mathrm{~mm}$ SL). This character was coded as absent (state 0) for Tatia aulopygia, because the ligament is absent in the available specimen of Tatia aulopygia (MZUSP 37599). This character was coded as missing data for all species of Mochokidae (except Synodontis), and for the auchenipterid Spinipterus.

215. Humerovertebral ligament: 0- absent; 1- present (CI 1.0, RI 1.0).

There is a ligament between the parapophysis of the fifth or sixth vertebra and posterior process of cleithrum, the humerovertebral ligament of de Pinna (1996), in all members of the Sisoroidea, and in the Aspredinidae (de Pinna, 1996: \#64; Diogo, 2004: \#164), this structure is absent in other examined taxa. This character was coded as missing data for the auchenipterid Spinipterus.

216. Aortic canal: 0- ventrally opened; 1 - ventrally enclosed by superficial ossification (CI 0.111, RI 0.6).

The complex vertebra is covered ventrally by a superficial ossification in most catfishes (Figs. 35a,b,e,f). However, in members of the ariid Genidens (Alexander, 1964: 435; Arratia, 1992: \#55; Marceniuk et al., 2012: \#69), Aspredinidae, Auchenipteridae (except Auchenipterus, Epapterus, Pseudotatia), Doradidae (except Rhynchodoras), Erethistidae, 
and mochokid Chiloglanis, the superficial ossification also covers the aorta, forming the aortic canal (Figs. 35c,d,g,h, 36; Higuchi, 1992: \#71, \#72; Sousa, 2010: \#49). Some specimens of the auchenipterids Centromochlus, Liosomadoras and Tatia, and doradid Rhinodoras dorbignyi present ventrally opened aortic canal whereas others have it closed; this character was coded as polymorphic for these taxa. This character was coded as missing data for the auchenipterid Spinipterus.

217. First free vertebra (ordered): 0 - fifth; 1 - sixth; 2 - seventh; 3- eighth, 4- ninth (CI 0.235, RI 0.787).

The fifth vertebra is free from the complex vertebra only in the Diplomystidae and Nematogenyidae (Lundberg, 1970: \#86; Arratia, 1992: \#40; de Pinna, 1993: \#208; de Pinna et al., 2007: \#87; Marceniuk et al., 2012: \#204). The first vertebra free from the complex vertebra is the sixth in the Amphiliidae, Aspredinidae, Claroteidae, Erethistidae, Heptapteridae, Ictaluridae, Malapteruridae, Pseudopimelodidae, Sisoridae, ariid Galeichthys, auchenipterid Gelanoglanis, and doradids Astrodoradinae, Acanthodoras, Agamyxis, Franciscodoras, Kalyptodoras, and Wertheimeria (Figs. 35b,h; Higuchi, 1992: \#68; Sousa, 2010: \#50). The first free vertebra is the seventh in the Mochokidae, Pangasiidae, Pimelodidae, Siluridae (Fig. 35f; Vigliotta, 2008: \#82), and auchenipterid Pseudepapterus. The first free vertebra is the eighth in the ariid Genidens, auchenipterids Ageneiosus, Asterophysus, Auchenipterus, Entomocorus, Epapterus, Glanidium, Liosomadoras, Pseudauchenipterus, Pseudotatia, Tatia, Tetranematichthys, Trachelyichthys, doradids Anduzedoras, Centrochir, Centrodoras, Doras, Hassar, Hemidoras, Leptodoras, Nemadoras, Orinocodoras, Ossancora, Oxydoras, Platydoras, Rhinodoras, Rhynchodoras, Tenellus and Trachydoras (Figs. 35d, 36a-c). The first free vertebra is the ninth in the auchenipterids Auchenipterichthys, Centromochlus heckelii, Tocantinsia, Trachelyopterichthys, Trachelyopterus, Trachycorystes, and doradids Doraops, Lithodoras, Megalodoras, and Pterodoras (Figs. 36d). This character was coded as missing data for the auchenipterid Spinipterus.

218. Hipertrophied bony nodule on parapophysis of sixth vertebra: 0 - absent; 1 - present (CI and RI inapplicable).

Among examined taxa, a hipertrophied bony nodule is present on the parapophysis of the sixth vertebra only in the doradids Oxydoras niger and O. sifontesi (Fig. 25; Higuchi, 1992: \#A53). This character was coded as missing data for the auchenipterid Spinipterus.

219. Articulation of anterior ribs: 0 - ventral; 1 - dorsal (CI 1.0, RI 1.0).

In most catfishes, the anterior ribs articulate with the ventral face of the parapophysis (the posterior ribs are articulated either to the posterior or dorsal face of the parapophysis) (Figs. 35b,d,f). However, in the Auchenipteridae and Doradidae the anterior ribs articulate with the dorsal face of the parapophysis (Figs. 35h, 36; Ferraris, 1988: \#V12; Vigliotta, 2008: \#84). This character was coded as missing data for the auchenipterid Spinipterus.

220. Shape of proximal extremity of ribs: 0 - straight; 1 - twisted (CI 0.333, RI 0.867).

Among examined species, the proximal extremity of the ribs is twisted only in the Amphiliidae, Aspredinidae, Auchenipteridae, Doradidae, Erethistidae, and Sisoridae (Figs. 35h, 36; Ferraris, 1988: \#V12; de Pinna, 1993: \#198; Britto, 2002: \#239; Vigliotta, 2008: \#84). This character was coded as missing data for the auchenipterid Spinipterus.

221. Number of ribs (ordered): 0 - three to five; 1 - six to 11 ; 2 12 or more (CI 0.154, RI 0.577).

The number of ribs in catfishes is highly reduced when compared to other members of the Ostariophysi, and several groups show yet a greater reduction (de Pinna, 1996: \#73). The Claroteidae, Mochokidae (except Mochokus), Pseudopimelodidae, Siluridae, Sisoridae, some Malapteruridae, and most members of Auchenipteridae and Doradidae have six to 11 ribs. The exceptions are the auchenipterids Ageneiosus brevis, Epapterus, and Pseudepapterus with four or five ribs (Walsh, 1990: \#31); auchenipterids Glanidium, Tocantinsia, and Asterophysus, and doradids Centrodoras, Doraops, Kalyptodoras, Lithodoras, Megalodoras, Oxydoras, Pterodoras, and Wertheimeria with 12 or more ribs (Sousa, 2010: \#52). Some specimens of the auchenipterids Ageneiosus inermis and Centromochlus heckelii, and doradids Platydoras armatulus and Oxydoras niger have 11 or less ribs while others have 12 or more; this character was coded as polymorphic $(1,2)$ for these taxa. This character was coded as missing data for the doradid Oxydoras kneri, and for the auchenipterid Spinipterus.

222. Number of vertebrae (ordered): 0 - 29 to 37 ; 1 - 38 to 45 ; 246 or more (CI 0.111, RI 0.698).

Most catfishes have between 38 and 45 vertebrae. However, examined specimens of the Amphiliidae, Ariidae, Heptapteridae, Ictaluridae, Pimelodidae, and Siluridae have 46 or more vertebrae, whereas those of the Aspredinidae, Erethistidae, Mochokidae (except Synodontis schall and S. zambezensis), Pseudopimelodidae, and Sisoridae on the other hand, have 29 to 37 vertebrae.

The auchenipterid Gelanoglanis, and doradids Astrodoradinae, Acanthodoras, Agamyxis, Centrochir, Doras (except some specimens of D. higuchii), Franciscodoras, Hassar, Hemidoras (except some specimens of $H$. morrisi and $H$. stenopeltis), Platydoras, Nemadoras, Orinocodoras, Ossancora, Rhinodoras, Tenellus, and Trachydoras (Sousa, 2010: \#53) have 29 to 37 vertebrae. Fortysix or more vertebrae are present in distal species of the doradids Leptodoras (sensu Birindelli et al., 2008), some specimens of Lithodoras, and auchenipterids Ageneiosus inermis, Auchenipterus, Pseudepapterus, Tetranematichthys 
(except some specimens of T. quadrifilis), Trachelyopterichthys and some specimens of Trachelyopterus galeatus (Walsh, 1990: \#28). Britski (1972: 18) observed that a species with an elongate body tends to have more vertebrae. This character was coded as polymorphic for doradids Doras higuchii, Hemidoras morrisi, Hemidoras stenopeltis $(0,1)$, Lithodoras dorsalis, and auchenipterids Tetranematichthys quadrifilis and Trachelyopterus galeatus $(1,2)$; and as missing data for the doradid Oxydoras kneri and auchenipterid Spinipterus.

\section{Dorsal fin}

223. Bones of cephalic shield: 0 - compact; 1 - trabeculate (CI 1.0, RI 1.0).

In the auchenipterids Ageneiosus and Tetranematichthys the cephalic-shield bones are trabeculate (Fig. 31; Britski, 1972: 12; Royero, 1999: \#30), whereas they are compact in all other examined taxa (Fig. 20-30).

224. Transverse dorsal margin of cephalic shield: 0- slightly convex, forming an angle greater than $90^{\circ} ; 1$ - strongly arched, forming an angle of approximately $90^{\circ}$ (CI 0.333, RI 0.956).

In the mochokid Synodontis and all doradids except Acanthodoras, Agamyxis, Kalyptodoras, and Wertheimeria, the cephalic shield is strongly arched, with the transverse dorsal margin forming an angle of approximately $90^{\circ}$ (Sousa, 2010: \#55). The cephalic shield is slightly convex, with angle greater than $90^{\circ}$ in all other examined species.

225. Lateral profile of cephalic shield in mature males: 0approximately straight, similar to females; 1 - distinctly concave, straight in females (CI 1.0, RI 1.0).

In mature males of auchenipterids Ageneiosus, Tetranematichthys, and some species of Trachelyopterus (including T. striatulus and T. porosus) the cephalic shield is distinctly concave in lateral view, whereas in females and immature males it is approximately straight, as in males and females of all other examined species (Ferraris, 1988: N19; Akama, 2004: \#173). This character was coded as missing data for the auchenipterid Spinipterus.

226. Nuchal foramen (ordered): 0 - absent; 1 - well developed; 2- weakly developed (CI 0.5, RI 0.905).

Among examined species of catfish, there is a nuchal foramen between the parietal-supraoccipital, epiotic and anterior nuchal plate (or middle nuchal plate, when the anterior one is reduced or absent) only in doradids Anduzedoras, Hassar, Hemidoras, Leptodoras, Nemadoras, Ossancora fimbriata, and Tenellus (Fig. 27; Higuchi, 1992: \#82, \#83; Sabaj, 2002: \#19). In Anduzedoras, Leptodoras copei, L. oyakawai and $L$. praelongus, the nuchal foramen is present and well developed in small specimens and reduced, or sometimes completely occluded in larger specimens (Birindelli et al., 2008: 476). In a few species of Doradinae, there is also intra-specific variation, wherein some specimens may have the foramen occluded (Sabaj, 2002: fig. 66). This character was ordered according to the ontogenetical development of the nuchal foramen.

227. Supraneural: 0- present; 1 - absent (CI 0.333, RI 0.333).

Among catfishes, the supraneural is absent only in the Amblycipitidae, Amphiliidae, Astroblepidae, Clariidae, Loricariidae, Malapteruridae, Nematogenyidae, Trichomycteridae, and Siluridae (Britto, 2002: \#280; de Pinna et al., 2007: \#108). This character was coded as missing data for the auchenipterid Spinipterus.

228. Anterior nuchal plate: 0 - present; 1 - absent (CI 0.125, RI $0.462)$.

In most catfishes, the supraneural is dorsally expanded into a bony plate, referred to as the anterior nuchal plate. This element precedes two other bony plates, the middle and posterior nuchal plates, derived from the first two pterygiophores of the dorsal fin, respectively (Fig. 20). Each of the three elements is ontogenetically formed from separate ossification centers, thus the derived pterygiophores have no trace of being formed by distinct proximal and distal radials. The only difference between the supraneural and the first two pterygiophores is that the latter support rays: the spinelet and the dorsal-fin spine, respectively. A few authors, including Arratia (2003b), interpreted the anterior nuchal plate as a homolog of the first pterygiophore, instead of the supraneural (thereby absent in catfishes). However, as discussed by Alexander (1965), this idea admits that the first dorsal-fin ray (presumably supported by the first pterygiophore) was lost in catfishes.

The anterior nuchal plate is absent in the Erethistidae, Sisoridae, doradids Nemadoras humeralis, Tenellus trimaculatus, T. ternetzi, Rhynchodoras, and auchenipterids Ageneiosus, Epapterus, Gelanoglanis, Glanidium cesarpintoi, Pseudepapterus, Tetranematichthys, some species of Centromochlus (Figs. 27, 31; Britski, 1972: 27; Ferraris, 1988: \#D1; Walsh, 1990: \#4; Soares-Porto, 1998: \#9; Royero, 1999: \#26; Akama, 2004: \#32, \#40; Sousa, 2010: \#54), and mochokids Atopodontus, Chiloglanis, Euchilichthys and Synodontis (S. nigriventris, S. batesii, S. contracta) (Vigliotta, 2008:\#19).

Although some authors concluded that, in some of those taxa, the anterior nuchal plate is fused to the middle nuchal plate (Royero, 1987: 132; Higuchi, 1992: 123; Akama, 2004: \#40) or to the parietal-supraoccipital (Soares-Porto, 1996: 138), the study of an ontogenetic series of doradid Rhynchodoras woodsi demonstrated that the absence of the anterior nuchal plate is due to a gradual reduction and loss of this element, leaving the space to be occupied by the middle nuchal plate (Birindelli et al., 2007: 680). Nevertheless, in some other catfishes (e.g., Akysidae, Erethistidae, Scoloplacidae, Sisoridae, and callichthyids Aspidoras and Corydoras), the anterior nuchal plate may actually fuse into the middle nuchal plate (de Pinna, 1996: fig. 35; Britto, 2002: \#280). This character was coded as inapplicable in the Amblycipitidae, Amphiliidae, Astroblepidae, Clariidae, Loricariidae, Malapteruridae, 
Nematogenyidae, Trichomycteridae, and Siluridae, which lack a supraneural; and as missing data for the auchenipterid Spinipterus.

229. Anterior nuchal plate and parietal-supraoccipital: 0 - in contact but not sutured; 1- sutured (CI 1.0, RI 1.0).

In most catfishes, the anterior nuchal plate assumes a triangular shape fitted into the posterior $\mathrm{V}$-shaped border of the parietal-supraoccipital (Fig. 20; Arratia, 1987; Lundberg, 1970; Royero, 1987). However, in the Auchenipteridae, Doradidae, and Mochokidae, the anterior nuchal plate is sutured to the parietal-supraoccipital (Figs. 21-26, 28-30; Chardon, 1968: 229; Mo, 1991: \#99; Royero, 1999: \#25, \#27; Britto, 2002: \#282; Akama, 2004: \#40). This character was coded as inapplicable for the Amphiliidae, Malapteruridae, Siluridae, Nematogenyidae, doradids Nemadoras humeralis, Tenellus trimaculatus, Tenellus ternetzi, Rhynchodoras, and auchenipterids Gelanoglanis, Ageneiosus, Epapterus, Pseudepapterus and Tetranematichthys, which lack an anterior nuchal plate; and as missing data for the auchenipterid Spinipterus.

230. Anterior nuchal plate and posttemporal-supracleithrum: 0- separated; 1- in contact (CI 0.5-1.0, RI 0.0-1.0).

Among examined species, there is contact between the anterior nuchal plate and the posttemporal-supracleithrum only in the mochokids Mochokiella and Mochokus (Vigliotta, 2008: \#18). This character was coded as inapplicable for the Amphiliidae, Malapteruridae, Siluridae, Nematogenyidae, doradids Nemadoras humeralis, Tenellus trimaculatus, Tenellus ternetzi, Rhynchodoras, and auchenipterids Gelanoglanis, Ageneiosus, Epapterus, Pseudepapterus and Tetranematichthys, which lack an anterior nuchal plate; and as missing data for the auchenipterid Spinipterus.

231. Middle nuchal plate and parietal-supraoccipital: 0separated; 1 - in contact (CI 0.111, RI 0.68).

In most catfishes, the middle nuchal plate is separated from the parietal-supraoccipital (Figs. 20-26, 28-30). However, there is contact between the middle nuchal plate and the parietalsupraoccipital in the auchenipterids Ageneiosus, Gelanoglanis, Glanidium cesarpintoi, Pseudepapterus, Tetranematichthys, and some species of Centromochlus (Fig. 31; Britski, 1972: 27; Ferraris, 1988: \#D3; Walsh, 1990: \#4; Soares-Porto, 1998: \#9; Royero, 1999: \#23; Akama, 2004: \#35, \#126), doradids Anduzedoras, Hassar, Hemidoras, Leptodoras praelongus, Ossancora asterophysa, O. eigenmanni, O. fimbriata, Nemadoras, Tenellus, Rhynchodoras, some specimens of Ossancora fimbriata and Oxydoras niger (Fig. 27; Britski, 1972: 27; Higuchi, 1992: \#84; Sabaj, 2002: \#18), and mochokids Atopodontus, Chiloglanis, Euchilichthys and Synodontis (S. nigriventris, S. batesii, S. contracta) (Vigliotta, 2008:\#20). This character is coded polymorphic for Ossancora fimbriata and Oxydoras niger; as inapplicable for the Malapteruridae, which lack a middle nuchal plate; and as missing data for the auchenipterid Spinipterus.
232. First and second pterygiophores articulated via a process: 0- absent; 1- present (CI 0.5, RI 0.667).

The first and second pterygiophore are articulated via a process in the Amphiliidae, Akysidae, Aspredinidae, Bagridae, Erethistidae, and Sisoridae (de Pinna, 1996: \#90; Britto, 2002: \#284). This character was coded as inapplicable for the Malapteruridae, which lack a middle nuchal plate; and as missing data for the auchenipterid Spinipterus.

233. Ventral portion of first dorsal-fin pterygiophore: 0smooth and laminar; 1- rugose and thick (CI 0.5, RI 0.667).

Among examined species, only in the Akysidae, Amblycipitidae, Amphiliidae, Aspredinidae, Erethistidae, and Sisoridae, the ventral portion of the first dorsal-fin pterygiophore and corresponding neural spine is rugose and thick (de Pinna, 1996: \#91; Britto, 2002: \#285). This character was coded as inapplicable for the Malapteruridae, which lack a middle nuchal plate; and as missing data for the auchenipterid Spinipterus.

234. First two dorsal-fin pterygiophores and corresponding neural spines: 0- not sutured; 1- sutured (CI 1.0, RI 1.0).

Among catfishes, the first two dorsal-fin pterygiophores (and usually the supraneural) are sutured to their corresponding neural spines, only in the Auchenipteridae, Chacidae, Doradidae, and Mochokidae (Fig. 35e,g; 1972: 26; Royero, 1987; Royero, 1999: \#75; Britto, 2002: \#286; Akama, 2004: \#125) whereas in other catfishes they are apart or united only by ligaments (Fig. 35a-c). This character was coded as inapplicable for the Malapteruridae, which lack a middle nuchal plate; and as missing data for the auchenipterid Spinipterus.

235. Dorsal-fin spinelet: 0- present; 1 - absent (CI 0.25, RI 0.25).

Among catfishes, the dorsal-fin spinelet is absent exclusively in the Amphiliidae, Aspredinidae, Astroblepidae, Cetopsidae, Clariidae, Malapteruridae, Nematogenyidae, Siluridae, and Trichomycteridae (Britto, 2002: \#288).

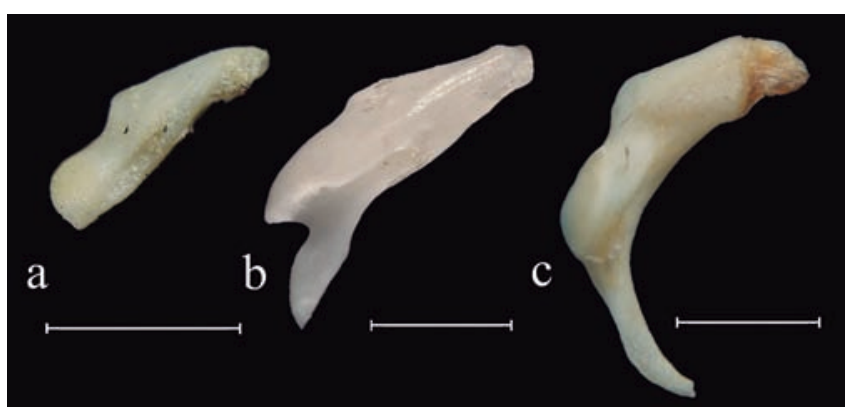

Fig. 58. Dorsal-fin spinelet in lateral view of (a) Ictalurus punctatus, MZUSP 103256, 155 mm SL; (b) Platydoras brachylecis, MZUSP no data; (c) Rhinodoras dorbignyi, MZUSP 61688, $102 \mathrm{~mm}$ SL. Scale bars equal $5 \mathrm{~mm}$. 
236. Ventral processes of dorsal-fin spinelet: 0 - short; 1 - long (CI 1.0, RI 1.0).

Among examined species, the ventral processes of the dorsal-fin spinelet are elongate, reaching ventrally the middle of the pterygiophore only in the Akysidae, Amblicipitidae, Auchenipteridae, Doradidae, Mochokidae, Erethistidae, and Sisoridae (Fig. 58b-c; Ferraris, 1988: \#D7; de Pinna, 1993: \#233; de Pinna, 1996: \#88; Royero, 1999: \#76; Britto, 2002: \#289). This character was coded as inapplicable in the Amphiliidae, Aspredinidae, Malapteruridae, Nematogenyidae, and Siluridae, which lack the dorsal-fin spinelet; and as missing data for the auchenipterid Spinipterus.

237. Number of branched dorsal-fin rays (ordered): 0 - six to eight; 1 - five; 2- four; 3- three (CI 0.273, RI 0.5).

In most catfishes there are usually six or seven branched rays in the dorsal fin (Lundberg, 1970; Royero, 1987, 1999; Arratia, 2003b). Most species of Auchenipteridae and Doradidae have six branched dorsal-fin rays. However, the doradid Acanthodoras (Eigenmann, 1925: 283; Sousa, 2010: \#59), and auchenipterids Centromochlus heckelii, Entomocorus, Gelanoglanis, Glanidium, Pseudepapterus, Spinipterus, Trachelyopterus, Trachycorystes, and Tatia aulopygia have five branched dorsal-fin rays (Britski, 1972: 29; Akama, 2004: \#128); Trachelyichthys and Trachelyopterichthys have four (Ferraris, 1988: D13; Royero, 1999: \#78), and Epapterus has only three (Vari \& Ferraris, 1998). Although most mochokids have six or seven branched dorsal-fin rays, some species of Chiloglanis have only five (Vigliotta, 2008: \#64). This character was coded as inapplicable for the Malapteruridae, which lack a dorsal fin.

238. Size of dorsal-fin spine (ordered): 0 - greatly reduced; 1 moderate, less than one-third of SL; 2- elongate, approximately one-third of SL (CI 1.0, RI 1.0).

In the auchenipterids Centromochlus existimatus and $C$. heckelii, the dorsal-fin spine is elongate, approximately onethird of the SL (Soares-Porto, 1998: \#23). In the auchenipterids Epapterus and Pseudepapterus, on the other hand, the dorsalfin spine is extremely reduced in size and thickness (Fig. 38c; Britski, 1972: 27; Ferraris, 1988: \#D13; Curran, 1989: \#14; Ferraris, \& Vari, 2000; Akama, 2004:\#127). This character was coded as inapplicable for the Malapteruridae, which lack a dorsal fin.

239. Size of dorsal-fin spine in mature males: 0 - same as that of females and immature males; 1 - distinctly longer than that of females and immature males (CI 0.167, RI 0.444).

In the auchenipterids Ageneiosus, Entomocorus, Epapterus, Liosomadoras, Tetranematichthys, Trachelyichthys, Trachelyopterichthys, Trachelyopterus, the dorsal-fin spine is distinctly larger in mature males, relative to that of females and immature males (Royero, 1999: \#126; Akama, 2004: \#162). In all other examined species, the dorsalfin spine in mature males is about the same length as in females and immature males. This character was coded as inapplicable for the Malapteruridae, which lack a dorsal fin; and as missing data for the auchenipterids Pseudotatia and Spinipterus.

240. Arched dorsal-fin spine in mature males: 0- absent; 1present (CI 1.0, RI 1.0).

In mature males of the auchenipterids Ageneiosus, Tetranematichthys, Trachelyopterus porosus and T. striatulus (Akama, 2004: \#165), the dorsal-fin spine is arched. In all other examined species, the dorsal-fin spine in mature males is approximately straight. This character was coded as inapplicable for the Malapteruridae, which lack a dorsal fin; and as missing data for the auchenipterids Pseudotatia and Spinipterus.

241. Movement of dorsal-fin spine in mature males: 0- dorsalfin spine not extending anteriorly, forming an angle of approximately $90^{\circ}$ relative to long body axis when fully erected; 1- dorsal-fin spine extending anteriorly forming an angle of less than $90^{\circ}$ relative to long body axis when fully erected (CI 0.5 , RI 0.857).

In mature males of the auchenipterids Ageneiosus, Auchenipterus, Entomocorus, Epapterus, Liosomadoras, Pseudepapterus, Tetranematichthys, Trachelyopterus porosus, and T. striatulus (Fig. 42; Ferraris, 1988: \#D12; Royero, 1999: \#127; Akama, 2004: \#167), the dorsal-fin spine is capable of rotating anteriorly forming an angle of less than $90^{\circ}$ angle relative to long body axis when fully erected. In all other examined species, the dorsal-fin spine in mature males does not bend forward. This character was coded as inapplicable for Malapteruridae, which lack dorsal fin; and as missing data for the auchenipterids Pseudotatia and Spinipterus.

242. Serrations on anterior face of dorsal-fin spine: 0 - absent or rudimentary; 1- present (CI 0.091-0.1, RI 0.6-0.64).

The presence of serrations on the anterior face of the dorsalfin spine is highly variable among catfishes. Within examined taxa, serrations are present on the anterior face of dorsal-fin spine in the Ariidae, Doradidae (except Anadoras and some species of Amblydoras; Sousa, 2010: \#56), Pseudopimelodidae, mochokids Mochokus niloticus, some species of Synodontis (Vigliotta, 2008: \#62), auchenipterids Ageneiosus, Asterophysus, Auchenipterichthys, Centromochlus, Liosomadoras, Pseudotatia, Spinipterus, Tatia, Tetranematichthys, Trachelyichthys, Trachelyopterichthys and Trachycorystes (Royero, 1999: \#80; Akama, 2004 \#129). All other examined species lack serrations on anterior face of the dorsal-fin spine. This character was coded as inapplicable for the Malapteruridae, which lack a dorsal fin.

243. Serrations of anterior face of dorsal-fin spine in mature males: 0 - similar to those in females and immature males; 1 distinct from those in females and immature males (CI and RI inapplicable).

In mature males of the auchenipterids Ageneiosus inermis and a few species of Trachelyopterus (including T. insignis), 
the dorsal-fin spine is modified having serrations restricted to its basal and distal portions (Royero, 1999: \#128; Akama, 2004: \#166). This character was coded as inapplicable for the Malapteruridae, which lack a dorsal fin; and as missing data for the auchenipterids Pseudotatia and Spinipterus.

244. Number of series of serrations on anterior face of dorsalfin spine in mature males: 0 - none or one; 1- two (CI 1.0, RI 1.0).

Mature males of the auchenipterids Ageneiosus, Trachelyopterus porosus and T. striatulus have two series of serrations along the anterior face of the dorsal-fin spine (Fig. 42a; Akama, 2004: \#164). In all other examined species, there is only one (or none) series of serrations along anterior face of dorsal-fin spine in mature males. This character was coded as inapplicable for the Malapteruridae, which lack a dorsal fin; and as missing data for the auchenipterids Pseudotatia and Spinipterus.

245. Serrations on posterior face of dorsal-fin spine: 0 - absent; 1- present (CI 0.067, RI 0.548).

The presence of serrations on the posterior face of the dorsal-fin spine is highly variable among catfishes. Within examined taxa, posterior face of the dorsal-fin spine has serrations in the Ariidae (except Galeichthys), Claroteidae, Erethistidae, Pangasiidae, Pseudopimelodidae, mochokids Mochokiella and Synodontis (Vigliotta, 2008: \#63), auchenipterids Asterophysus, Auchenipterichthys, Centromochlus, Entomocorus, Liosomadoras, Pseudauchenipterus, Spinipterus, Tetranematichthys, Trachelyichthys, Trachelyopterichthys and Trachelyopterus (Royero, 1999: \#79; Akama, 2004:\#130), and Doradinae (except Leptodoras juruensis, and some specimens of Platydoras; Sousa, 2010: \#57). All other examined species lack serrations on posterior face of the dorsal-fin spine. This character was coded as inapplicable for Malapteruridae, which lack dorsal fin; and as polymorphic for Platydoras armatulus and Platydoras sp.
246. Size of serrations on posterior face of dorsal-fin spine in mature males: 0 - moderate, similar to those of females; 1 hypertrophied, stronger than those of females (CI 0.5, RI $0.0)$.

In mature males of the auchenipterids Auchenipterichthys and Trachelyopterichthys, the serrations on the distal portion of the posterior face of the dorsal-fin spine are hypertrophied, stronger than those of females (Ferraris \& Fernandez, 1987; Ferraris et al., 2005; Akama, 2004: \#163). This feature was not present in the examined specimens of Liosomadoras, although mentioned by Akama (2004: \#163). This character was coded as inapplicable for the Malapteruridae, which lack a dorsal fin; and as missing data for the auchenipterids Pseudotatia and Spinipterus.

247. Serrations on lateral face of dorsal-fin spine: 0 - absent; 1- present (CI 0.5, RI 0.5).

Among examined species, only the doradids Acanthodoras and Agamyxis, and auchenipterid Spinipterus (Akama \& Ferraris, 2011) have serrations on the lateral face of the dorsal-fin spine (Sousa, 2010: \#58). This character was coded as inapplicable for the Malapteruridae, which lack a dorsal fin.

248. Number of pairs of inclinatores dorsales muscles of dorsal fin (ordered): 0 - one; 1 - two; 2 - three; 3 - four (CI 0.375 , RI 0.444).

Most catfishes have a single pair of inclinatores dorsales muscles of the dorsal fin. The auchenipterids Ageneiosus atronasus, A. brevis and A. ucayalensis have two pairs of inclinatores dorsales muscles on the dorsal fin (Fig. 59a), whereas Ageneiosus inermis, A. magoi, Pseudepapterus and Trachelyopterus have three (Fig. 59b), and Tetranematichthys has four (Akama, 2004: \#131; Royero, 1999: table 3). This character was coded as missing data for Epapterus, Gelanoglanis, Pseudotatia, and Spinipterus; and coded as inapplicable for Malapteruridae, which lack dorsal fin.

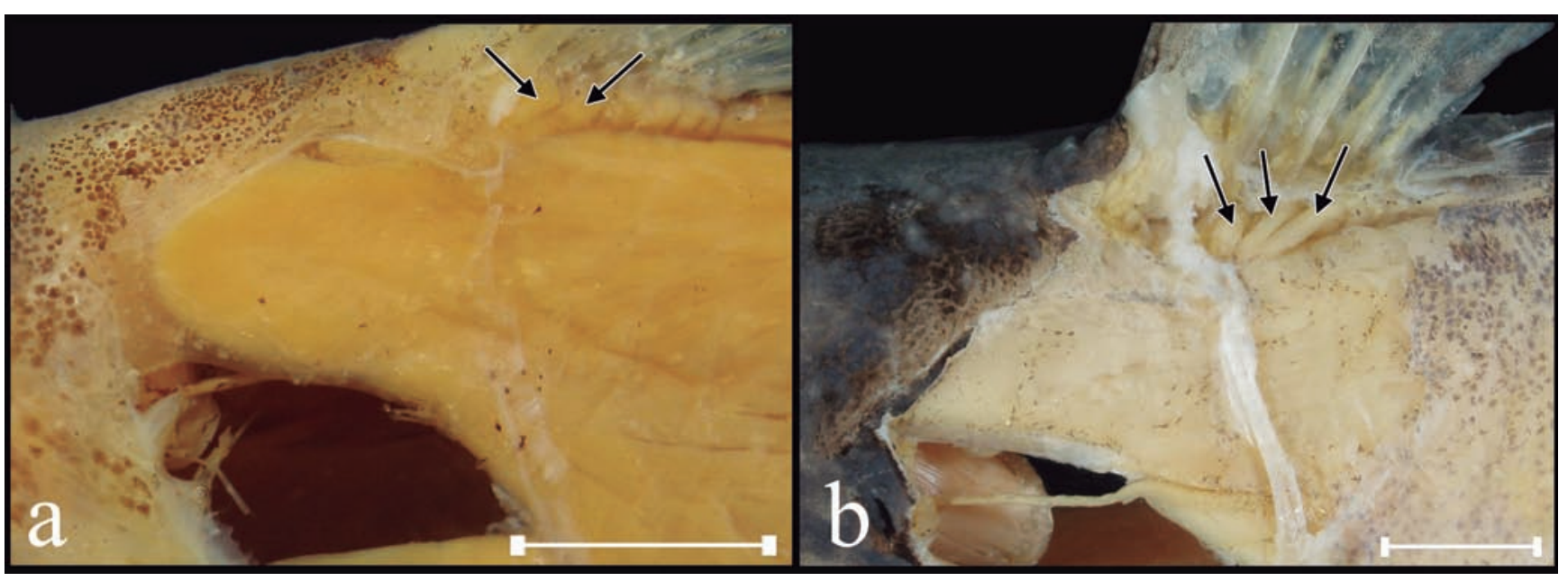

Fig. 59. Dorsal-fin base in dorsolateral view of (a) Ageneiosus atronasus, MZUSP 52620, 80.1 mm SL; (b) Trachelyopterus striatulus, MZUSP 90742, 154 mm SL. Arrows indicate inclinatores dorsales muscles. Scale bars equal 5 mm. 


\section{Pectoral girdle}

249. Anterior margin of pectoral girdle (ordered): 0 - arched, slightly convex; 1- elongate anteriorly, with truncate tip; 2elongate anteriorly with acute tip (CI 0.167, RI 0.783).

In most catfishes, the anterior margin of the pectoral girdle in ventral view is arched, slightly convex (Figs. 60d,g, 61). However, in the doradids Anduzedoras, Doras, Hassar, Hemidoras, Oxydoras, Nemadoras, Tenellus and most basal species of Leptodoras, the pectoral girdle is anteriorly elongate, but with a truncate tip (Figs. 60f,i). In the auchenipterids Asterophysus, Centromochlus, Entomocorus, Gelanoglanis, Pseudauchenipterus, Pseudotatia, Tatia (Britski, 1972; SoaresPorto, 1998: \#18), and doradids Leptodoras juruensis and Trachydoras (Higuchi, 1992: \#97), the pectoral girdle is anteriorly elongate with acute tip (Figs. 60e,h).

250. Mesocoracoid: 0- present; 1 - absent (CI 0.333, RI 0.875).

The mesocoracoid is present as a small arch on the posterior face of the pectoral girdle in most catfishes. However, it is absent in the Anchariidae, Ariidae, Aspredinidae, Auchenipteridae, and Doradidae (Figs. 60, 61; Regan, 1911; Ferraris, 1988: \#P1; Royero, 1999: \#82; Britto, 2002: \#247; Akama, 2004: \#105; Diogo, 2004: \#185; Vigliotta, 2008: \#55; Marceniuk et al., 2012: \#219). This character was coded as missing data for the auchenipterid Spinipterus.

251. Cleithrum-coracoid bridge: 0 - present; 1 - absent (CI 0.5, RI 0.0).
There is a bony bridge between the cleithrum and coracoid, near the articular fossa of pectoral-fin spine in most catfishes (Figs. 60-61). However, in the Malapteruridae, Nematogenyidae and some species of Amphiliidae (not including Amphilius jacksoni, herein examined) the cleithrumcoracoid bridge is absent (Diogo, 2003: 420; Diogo, 2004:\#192).

252. Length of cleithrum-coracoid bridge: 0 - short, restricted to articulation fossa of pectoral-fin spine; 1- long, continuous to coracoid posterior process (CI and RI inapplicable).

In most catfishes, the bony bridge between the cleithrum and coracoid is short, restricted to articulation fossa of the pectoral-fin spine. However, the cleithrum-coracoid bridge is elongate, continuous to the coracoid posterior process, in the auchenipterid Entomocorus. This character was coded as inapplicable for the Malapteruridae and Nematogenyidae.

253. Pectoral-fin spine locking foramen: 0 - present; 1 - absent (CI 0.2, RI 0.886).

Most catfishes have a pectoral-fin spine locking foramen on the medial wall of the coracoid, which fits the tip of the medial process of the head of the pectoral-fin spine, when the spine is extended. However, that foramen is absent in the Amphiliidae, Ariidae, Doradidae, auchenipterid Trachelyopterus (Royero, 1999: \#83), and mochokids Atopochilus, Atopodontus, Chiloglanis (except C. macropterus) and Euchilichthys (Vigliotta, 2008: \#57). This character was coded as missing data for the auchenipterid Spinipterus.

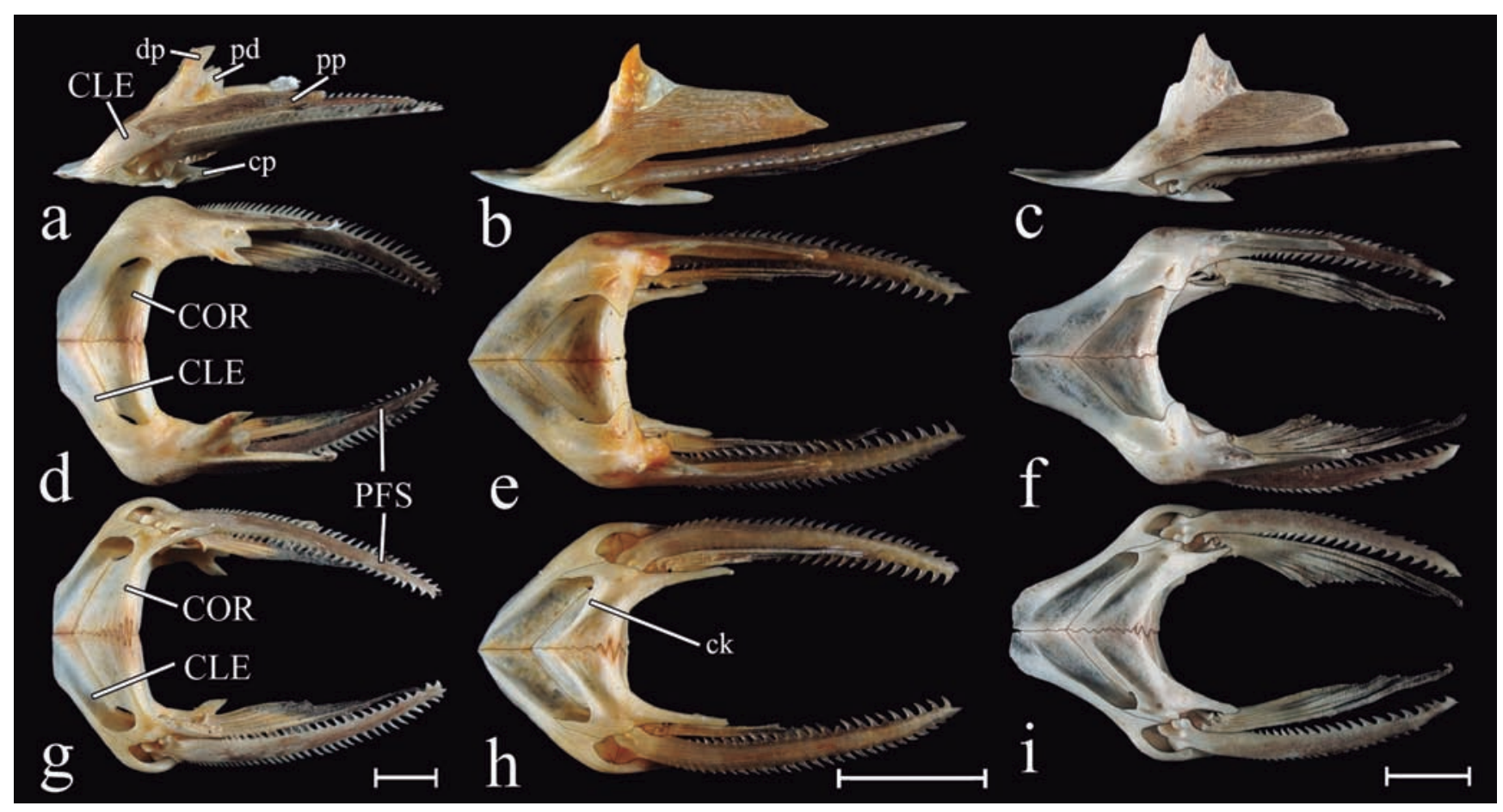

Fig. 60. Pectoral girdle in lateral (upper row), dorsal (middle row) and ventral (lower row) views of (a,d,g) Wertheimeria maculata, MZUSP 93658, 220.0 mm SL; (b,e,h) Trachydoras brevis, MZUSP 103087, 74 mm SL; (c,f,i) Doras higuchii, MZUSP 101693, 182 mm SL. CLE cleithrum, COR coracoid, cp coracoid process, dp dorsal cleithral process, pd posterodorsal cleithral process, PFS pectoral-fin spine, pp posterior cleithral process. Scale bars equal $10 \mathrm{~mm}$. 
254. Process of first proximal radial of pectoral fin (ordered): 0 - absent; 1- extended ventrally; 2- extended ventral and dorsally (CI 0.333, RI 0.5).

Among examined species, there is a process that extends ventrally on the first proximal radial of the pectoral fin only in the Claroteidae, Pangasiidae, Schilbeidae (Britto, 2002: \#253) and some species of Mochokidae (including Mochokiella and Synodontis; Vigliotta, 2008: \#58). Furthermore, in the Ariidae and mochokid Chiloglanis, the process extends both ventrally and dorsally (Vigliotta, 2008: \#58). This character was coded as missing data for the auchenipterid Spinipterus.

255. Size of second proximal radial of pectoral fin: 0- moderate, supporting fewer than three rays; 1- large, supporting more than three rays (CI 1.0, RI 1.0).

The second proximal radial of the pectoral fin is extremely enlarged distally and supports several rays in the auchenipterids Ageneiosus and Tetranematichthys (Figs. 61f,i; Ferraris, 1988: \#P9; Walsh, 1990: \#6; Royero, 1999: \#90; Akama, 2004: \#115). Although, in Ageneiosus atronasus this element is not as large as in congeners, it is distinctly larger than in most auchenipterids. This character was coded as inapplicable for the auchenipterid Gelanoglanis, which lack the second proximal radial; and as missing data for the auchenipterid Spinipterus.
256. Dorsal process of base of pectoral-fin spine: 0- small, non-discoid, and weakly attached to cleithrum; 1- large, discoid, firmly attached to cleithrum (CI 1.0, RI 1.0).

Among examined species, only in the auchenipterid Ageneiosus the base of the pectoral-fin spine has a small, non-discoid dorsal process that is weakly attached to cleithrum (Royero, 1999: \#86; Akama, 2004: \#117).

257. Serrations on anterior face of pectoral-fin spine: 0- absent; 1- present (CI 0.1, RI 0.438).

The presence of serrations on the anterior face of the pectoral-fin spine is highly variable among catfishes (Arratia, 1987). These serrations are present in the Ariidae, Aspredinidae (except Xyliphius), Auchenipteridae (exceptions listed below), Bagridae, Clariidae, Claroteidae, Doradidae, Heptapteridae, Ictaluridae (except Pylodictis olivaris), Pangasiidae, Pimelodidae, Pseudopimelodidae, Schilbeidae, sisorid Sisor and some species of Mochokidae (including Mochokiella, Mochokus, and Synodontis) (Britto, 2002: \#255; Vigliotta, 2008: \#59). The auchenipterids Ageneiosus, Auchenipterus, Epapterus, Gelanoglanis, Pseudauchenipterus, Pseudepapterus, Tetranematichthys, and Trachelyopterus coriaceus lack serrations on anterior face of the pectoral-fin spine (Ferraris, 1988: \#P7; Soares-

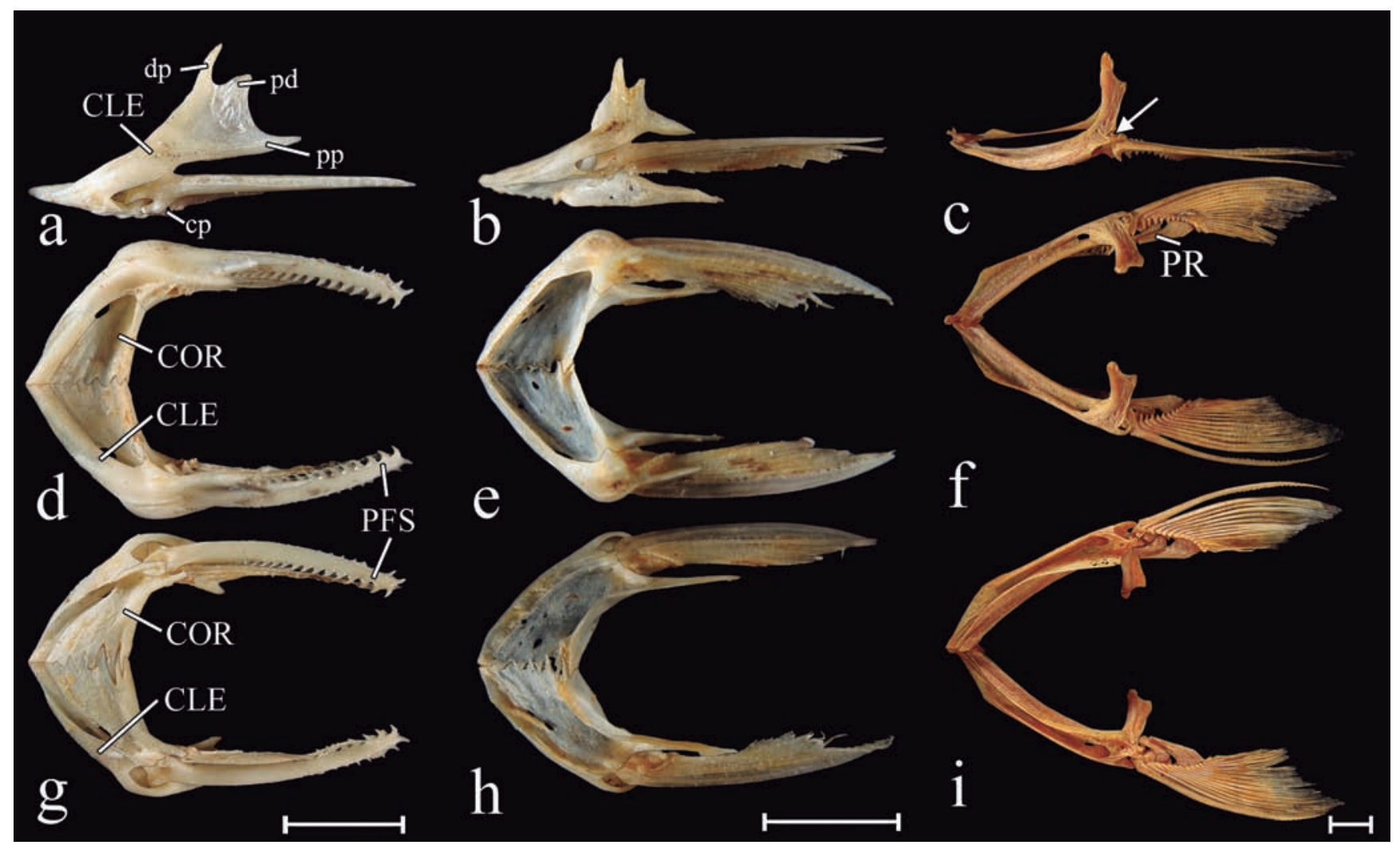

Fig. 61. Pectoral girdle in lateral (upper row), dorsal (middle row) and ventral (lower row) views of (a,d,g) Glanidium melanopterum, MZUSP 64256, 112 mm SL; (b,e,h) Auchenipterus nuchalis, MZUSP 89728, 141 mm SL; (c,f,i) Ageneiosus inermis, MZUSP 91661, 333 mm SL. CLE cleithrum, COR coracoid, cp coracoid process, dp dorsal cleithral process, pd posterodorsal cleithral process, PFS pectoral-fin spine, pp posterior cleithral process, PR pectoral-fin rays. Arrow indicated lateral fenestra of pectoral girdle. Scale bars equal $10 \mathrm{~mm}$. 
Porto, 1998: \#20; Royero, 1999: \#88; Walsh, 1990: \#34; Akama, 2004:\#107).

258. Orientation of serrations on anterior face of pectoral-fin spine: 0 - antrorse; 1 - retrorse (CI 0.5, RI 0.0).

In most catfishes, the serrations of the anterior face of the pectoral-fin spine are antrorse along the entire spine, or at least along the distal half. However, in the auchenipterids Centromochlus heckelii and Tocantinsia, those serrations are retrorse for the entire length of the pectoral-fin spine (Ferraris, 1988: \#P5). This character was coded as inapplicable for the Amphiliidae, Diplomystidae, Erethistidae, Malapteruridae, Nematogenyidae, Siluridae, Sisoridae, mochokid Chiloglanis, and auchenipterids Auchenipterus, Epapterus, Gelanoglanis, Pseudauchenipterus, Pseudepapterus, Tetranematichthys, and Trachelyopterus coriaceus, which lack spines on the anterior face of the pectoral fin.

259. Serrations on posterior face of pectoral-fin spine: 0present; 1- absent (CI 0.5, RI 0.5).

Most catfishes have serrations on the posterior face of the pectoral-fin spine. However, the Amphiliidae, Malapteruridae, and mochokid Chiloglanis (except $C$. macropterus) have the posterior face of the pectoral-fin spine without serrations (Vigliotta, 2008: \#60).

260. Serrations on dorsal face of pectoral-fin spine (unordered): 0 - absent; 1 - present on anterior portion; 2widespread (CI 0.667, RI 0.5).

Most catfishes have the dorsal face of the pectoral-fin spine without serrations. However, the auchenipterids Spinipterus, Trachelyopterichthys taeniatus, Trachelyopterus porosus, and T. striatulus have a row of serrations on distal portion of the dorsal face of the pectoralfin spine (Akama, 2004: \#110), and the doradids Acanthodoras and Agamyxis have serrations widespread over the dorsal face of the pectoral-fin spine (Sousa, 2010: \#74).

261. Length of pectoral-fin spine: 0 - moderate, less than onethird of SL; 1- elongate, longer than one-third of SL (CI and RI inapplicable).

The pectoral-fin spine in the auchenipterids Centromochlus existimatus and $C$. heckelii is elongate, longer than one-third of the SL (Ferraris, 1988: \#P2; Royero, 1999: \#91; Akama, 2004: \#106). In all other examined taxa, the pectoralfin spine is shorter than one-third of SL.

262. Number of branched pectoral-fin rays: 0- four to eight; 1- nine to 15 (CI 0.5, R 0.667).

Most catfishes have six to eight branched pectoral-fin rays (Lundberg, 1970: 51). Some species of the Auchenipteridae have more branched pectoral-fin rays (Walsh, 1990: \#30; Royero, 1999: \#87, \#151; Akama, 2004:\#118), including: Auchenipterus (with 10 to 14, Ferraris \& Vari, 1999: table 4), Epapterus (E. blohmi with eight to 10 , and E. dispilurus with 10 to 12 , Vari \&
Ferraris, 1998: 996), Pseudepapterus (with 10 to 14, Ferraris \& Vari, 2000: table 3) and Tetranematichthys (with nine to 11, Vari \& Ferraris, 2006: 174).

263. Lateral fenestra on cleithrum: 0 - absent; 1 - present (CI and RI inapplicable).

Among examined species, there is a small fenestra on the lateral surface of the cleithrum only in the auchenipterid Ageneiosus (except A. atronasus and A. brevis), (Figs. 61c,f; Royero, 1999: \#85; Akama, 2004: \#116). A similar condition occurs in the pimelodid Hypophthalmus (Diogo, 2004: \#160).

264. Posterodorsal process of cleithrum: 0 - well developed, with acute tip; 1- weakly developed, with obtuse tip (CI 0.5, RI 0.978).

In most catfishes, the dorsal tip of the cleithrum has two well-developed processes (with acute tip): one dorsal and one posterodorsal (Figs. 60, 61a; Tilak, 1963). However, the posterodorsal process is weakly developed, with an obtuse tip in all species of Doradidae, except Franciscodoras, Kalyptodoras, Leptodoras praelongus, and Wertheimeria (Figs. 60b-c; Sousa, 2010: \#61). This character was coded as missing data for the auchenipterid Spinipterus.

265. Posterior cleithral process (ordered): 0 - absent; 1 - length smaller than that of dorsal process; 2- length greater than that of dorsal process (CI 0.2, RI 0.704).

The posterior cleithral process is small in most catfishes, including the auchenipterids Gelanoglanis, Glanidium, Tatia aulopygia, Tetranematichthys Trachelyopterus galeatus, and T. insignis) (Fig. 61a; Akama, 2004), and mochokids Chiloglanidinae (Vigliotta, 2008: \#53). It is absent in several species, including the Amblycipitidae, Callichthyidae, Cetopsidae, Clariidae, Malapteruridae, Nematogenyidae, Siluridae, Trichomycteridae (Britto, 2002: \#246), and the auchenipterid Ageneiosus (Figs. 61c; Ferraris, 1988: \#P8; Walsh, 1990: \#5; Royero, 1999: \#84; Akama, 2004:\#112). The posterior cleithral process is large, its length greater than that of the dorsal process, in the Doradidae, Auchenipteridae (except Gelanoglanis, Glanidium, Tatia aulopygia, Tetranematichthys Trachelyopterus galeatus, and T. insignis), and Mochokidae (except Chiloglanidinae) (Figs. 60, 61).

266. Shape of posterior cleithral process (unordered): 0elongate, depth at base slightly greater than near tip; 1triangular, deep at base and tapering posteriorly; 2- trapezoidal, deep at base and near tip (CI 0.667, RI 0.967).

The posterior cleithral process in catfishes is usually elongate, tapering posteriorly (fig. 60a). However, in the doradids Orinocodoras, Rhinodoras, and Rhynchodoras, it is triangular, deep at its base and tapering posteriorly (Fig. 24; Higuchi, 1992: \#101), and in the doradids Anduzedoras, Doras, Hassar, Leptodoras, Nemadoras, Ossancora, Tenellus, and Trachydoras it is trapezoidal, deep at its base and near tip (Figs. 60b,c; Sabaj, 2002: \#20; Sousa, 2010: \#63). This character was coded as inapplicable for the Malapteruridae, 
Nematogenyidae, Siluridae, and auchenipterid Ageneiosus, which lack the posterior cleithral process.

267. Spines on posterior cleithral process: 0 - absent; 1 - present (CI 0.25, RI 0.667).

There are spines on the posterior cleithral process in the auchenipterids Liosomadoras, Spinipterus, Trachelyopterus porosus, Trachelyopterus fisheri, T. teaguei, and doradids Astrodoradinae, Acanthodoras, Agamyxis, Centrochir, and Platydoras (Fig. 22; Eigenmann, 1925: 287; Higuchi, 1992: \#99, \#A70; \#A72; Sousa, 2010: \#64; \#66; Curran, 1989: \#11; Akama, 2004: \#113; Higuchi et al., 2007: 33). This character was coded as 1 for Anadoras and Platydoras, although the spines may be inconspicuous in very large specimens of those species (specimens larger than $100 \mathrm{~mm} \mathrm{SL}$ ). On the other hand, this character was coded as 0 for doradids Franciscodoras, Megalodoras, and Pterodoras, even though very small specimens have spines on the posterior cleithral process (reported cases are MZUSP 97145, 30 mm SL, MZUSP 55838, $68 \mathrm{~mm}$ SL, MZUSP 82995, $60 \mathrm{~mm}$ SL, respectively). This character was coded as inapplicable for Malapteruridae, Nematogenyidae, Siluridae and auchenipterid Ageneiosus, which lack posterior cleithral process.

268. Arrangement of spines on posterior cleithral process (unordered): 0- scattered, widespread; 1- arranged in single row; 2- arranged in one main row accompanied by secondary rows (CI 0.667, RI 0.75).

In the auchenipterids Liosomadoras, Trachelyopterus porosus (Curran, 1989: \#11; Akama, 2004: \#113) and doradid Agamyxis (Eigenmann, 1925: 287; Higuchi, 1992: \#A70; Sousa, 2010: \#64), the spines are scattered and widespread on the posterior cleithral process. In the auchenipterids Spinipterus, Trachelyopterus fisheri, T. teaguei (Akama, 2004: \#113), and doradids Centrochir and Platydoras the spines are arranged in a single row on the posterior cleithral process. In the doradid Acanthodoras and in the species of Astrodoradinae, the spines of the posterior cleithral process are arranged in one main row accompanied by secondary rows (Higuchi, 1992: \#99, \#A72; Higuchi et al., 2007: 33; Sousa, 2010: \#66). This character was coded as inapplicable for all taxa that lack spines on the posterior cleithral process.

269. Suture between coracoids (ordered): 0- straight; 1 interdigitating from anterior to posterior border; 2interdigitating only near posterior border (CI 0.667, RI 0.5).

In most catfishes, the suture between the coracoids is interdigitating from anterior to posterior border (Figs. 60, 61; Britto, 2002: 249). However, in the Astroblepidae, Cetopsidae, Diplomystidae, Nematogenyidae, Siluridae, and Trichomycteridae, the suture between coracoids is straight (Mo, 1991; Grande \& de Pinna, 1998; de Pinna et al., 2007: \#103), whereas in the auchenipterid Pseudepapterus the suture is interdigitating only near the posterior border of the coracoids. This character was coded as missing data for the auchenipterid Spinipterus.
270. Posterior coracoid process (unordered): 0- short, extending slightly posterior than base of pectoral-fin rays; 1 elongate, thick and visually exposed; 2- elongate, laminar and not visually exposed (CI 0.333 , RI 0.636 ).

The posterior coracoid process is elongate (extending distinctly beyond base of rays), thick and visually exposed in the Aspredinidae, Erethistidae, Scoloplacidae, and Sisoridae (Alexander, 1965: 119; de Pinna, 1996: \#79; Britto, 2002: \#250). The same condition is present in the doradids Astrodoras, Ossancora, Physopyxis, and Trachydoras paraguayensis (Eigenmann, 1925: 287; Higuchi, 1992: \#106, A75; Sousa, 2010: \#71), and auchenipterids Auchenipterichthys coracoideus and A. thoracatus (Ferraris et al., 2005). In the auchenipterids Auchenipterus, Epapterus, and Pseudepapterus the posterior coracoid process is also elongate (extending distinctly beyond base of rays), laminar and not visually exposed (Figs. 61b,e,h).

271. Dorsoposterior border of coracoid: 0 - slightly elevated dorsally, length of transverse portion of coracoid much smaller than that of longitudinal portion; 1- extremely elevated dorsally, length of transverse portion of coracoid approximately equal of longer than that of longitudinal portion (CI 1.0, RI 1.0).

In most catfishes, the dorsoposterior border of the coracoid is only slightly elevated dorsally (i.e., length of transversal portion of coracoid is much smaller than that of longitudinal portion). In the doradids Anduzedoras, Doras, Hassar, Hemidoras, Leptodoras, Nemadoras, Ossancora, Oxydoras, Tenellus, and Trachydoras, the dorsoposterior border of the coracoid is extremely elevated dorsally, forming a bony diaphragm, and strongly associated with the ventral process of the transcapular process (Figs. 34b-d, 60e,f; Higuchi, 1992: \#102; Sousa, 2010: \#72). This character was coded as missing data for the auchenipterid Spinipterus.

272. Ventroposterior margin of coracoid: 0- laminar, developed as a shallow flap, not visually exposed in alcohol preserved specimens; 1- thick, visually exposed (CI 0.111, RI 0.6).

In most catfishes, the ventroposterior margin of the coracoid is laminar and developed as a shallow flap, not visually exposed in alcohol preserved specimens. However, in the Aspredinidae, auchenipterids Auchenipterichthys thoracatus, Centromochlus, and Trachelyopterus coriaceus (Soares-Porto, 1998: \#35), and doradids Acanthodoras, Agamyxis, Anadoras, Astrodoras, Hemidoras, Megalodoras, Ossancora, Scorpiodoras, Trachydoras paraguayensis, and T. steindachneri (Higuchi, 1992: \#105; Sousa, 2010: \#67), the ventroposterior border of the coracoid is thick and visually exposed in alcohol- preserved specimens. In some species of Astrodoradinae, this feature is further developed, and the entire ventral face of the pectoral girdle is visually exposed in some cases (Sousa \& Rapp Py-Daniel, 2005; Higuchi et al., 2007; Sousa, 2010).

273. Bony crest of coracoid between adductor superficialis and arrector ventralis muscles: 0 - absent; 1 - present (CI 0.2, RI 0.778). 
Among examined species, a bony crest is present on the ventral face of the coracoid between the adductor superficialis and arrector ventralis muscles in the Amphiliidae, Auchenipteridae (except Auchenipterus, Epapterus, and Pseudepapterus), Doradidae (except Rhynchodoras), Erethistidae and Mochokidae (Figs. 60g-i, 61g,i; Birindelli et al., 2007: 673). This character was coded as missing data for the auchenipterid Spinipterus.

274. Orientation of coracoid crest between adductor superficialis and arrector ventralis muscles: 0- oblique; 1transverse (CI 0.143, RI 0.571).

In most examined species, the bony crest of coracoid between adductor superficialis and arrector ventralis muscles is oblique, relative to long axis of body (Figs. 60g-i, 61g-i). However, in the doradids Acanthodoras, Centrochir, Centrodoras, Hemidoras morrisi, Platydoras, Megalodoras, Orinocodoras, Ossancora fimbriata, and Rhinodoras, and mochokid Synodontis schall, the coracoid crest is perpendicular to the long axis of body (Sousa, 2010: \#69). This character was coded as inapplicable for the Ariidae, Aspredinidae, Claroteidae, Diplomystidae, Heptapteridae, Ictaluridae, Malapteruridae, Nematogenyidae, Pangasiidae, Pimelodidae, Pseudopimelodidae, Siluridae, Sisoridae, auchenipterids Auchenipterus and Pseudepapterus, and doradid Rhynchodoras; and as missing data for the auchenipterid Spinipterus.

\section{Pelvic girdle}

275. Position of pelvic girdle: 0 - approximately halfway along SL; 1- within anterior half of SL (CI 1.0, RI 1.0).

In most catfishes, the pelvic girdle is located approximately midway along SL. However, the pelvic girdle is positioned in the anterior half of the body (SL) in Leptodoras (Higuchi, 1992: \#108; Birindelli \& Sousa, 2010).

276. Number of branched pelvic-fin rays (ordered): 0 - four or five; 1- six; 2- seven; 3- eight or more (CI 0.167, RI 0.659).

According to Shelden (1937), Lundberg (1970) and Grande (1987), catfishes in general have five (or sometimes only four) branched pelvic-fin rays. However, all species of Mochokidae (Vigliotta, 2008: \#65), and most species of Auchenipteridae and Doradidae have six. The exceptions include the doradids Acanthodoras, Agamyxis, Franciscodoras, Kalyptodoras, and Wertheimeria (Sousa, 2010: \#80), and auchenipterids Entomocorus (Akama \& Ferraris, 2004), Trachelyopterus (Akama, 2004), and most species of Centromochlinae (Mees, 1974) with five; auchenipterid Pseudauchenipterus with seven (Akama, 1999); and auchenipterids Asterophysus, Auchenipterichthys (Ferraris et al., 2005), Auchenipterus (Vari \& Ferraris, 1998), Epapterus (Ferraris \& Vari, 2000), Pseudepapterus (Ferraris \& Vari, 1999), Trachelyopterichthys (Ferraris \& Fernandez, 1987), Trachelyichthys and Trachycorystes, with eight or more branched pelvic-fin rays (Ferraris, 1988: \#PV3; Royero, 1999: \#92; Akama, 2004:\#122). In addition, the Ictaluridae has seven branched pelvic-fin rays, and Pangasiidae and Siluridae have eight or more. This character was coded as polimorphic $(0,1)$ for the auchenipterid Spinipterus (see Akama \& Ferraris, 2011).

\section{Pelvic splint: 0- present; 1 - absent (CI 0.25, RI 0.5).}

The pelvic splint, as discussed by Lundberg (1970: fig. 134) and Arratia (1987: 31), is present in the Bagridae (except Batasio and Olyra), Cetopsidae, Cranoglanidae, Diplomystidae, Ictaluridae (except Trogloglanis), Pangasiidae, Schilbeidae, Siluridae, Sisoridae, and was also reported to be present in the Trichomycteridae (Britto, 2002: \#279), and mochokids Chiloglanis and Synodontis (Vigliotta, 2008: \#66). The pelvic splint is absent in the Amphiliidae, Ariidae (Marceniuk et al., 2012: \#220), Aspredinidae, Auchenipteridae, Claroteidae, Doradidae, Erethistidae, Heptapteridae, Malapteruridae, Nematogenyidae, Pimelodidae, Pseudopimelodidae, and mochokids Mochokus and Mochokiella.

278. Cartilaginous radial of pelvic fin: 0 - present; 1 - absent (CI 0.2, RI 0.0).

Among examined taxa, the cartilaginous radial of the pelvic fin is absent only in the Aspredinidae, Auchenoglanidae, Chacidae, Diplomystidae, Malapteruridae, mochokid Synodontis and sisorid Bagarius (Lundberg, 1970; Britto, 2002: \#277). This character was coded as missing data for the auchenipterid Spinipterus.

279. First ray of pelvic fin in mature males: 0 - normal, as in females; 1 - modified, distinct from that of females (CI and RI inapplicable).

In mature males of the auchenipterid Entomocorus, the first ray of the pelvic fin is modified, enlarged and elongate (Ferraris, 1988: \#PV2, Royero, 1999: \#133; Akama \& Ferraris, 2003; Akama, 2004: \#170). The first ray of pelvic fin is not modified in mature males of all other examined species. This character was coded as missing data for the auchenipterids Pseudotatia and Spinipterus.

280. Spines on first two pelvic-fin rays: 0 - absent; 1 - present (CI and RI inapplicable).

Among examined species, only the doradid Agamyxis has spines on the dorsal and ventral faces of the first two pelvicfin rays (Sousa, 2010: \#81).

281. Bases of paired pelvic fin: 0- separated; 1 - united by membrane (CI 1.0, RI 1.0).

In the auchenipterids Auchenipterus, Epapterus, and Pseudepapterus, a membrane unites the medial portions of the paired pelvic-fin bases (Ferraris \& Vari, 1999: 393; Ferraris, 1988: \#PV6; Akama, 2004: \#123). This membrane is absent in all other examined species.

282. Contact between cartilages of anterior rami of basipterygium: 0- absent; 1- present (CI 0.333, RI 0.333).

The cartilages of the anterior ramus of the basipterygium 
contact each other in the Amphiliidae, Erethistidae, Sisoridae (except Pseudecheneis and Sisor), and mochokids Chiloglanis, Atopodontus, Atopochilus, and Euchilichthys (de Pinna, 1993: 212; Britto, 2002: \#263; Vigliotta, 2008: 68). In all other examined species, the cartilages of the anterior rami of the basipterygium are separated. This character was coded as missing data for the auchenipterid Spinipterus.

283. Anteromedial process of basipterygium (ordered): 0distinct, not united to basipterygium by bony lamina; 1- partially united to basipterygium by bony lamina; 2- completely united to basipterygium by bony lamina (CI 0.167, RI 0.762).

The anteromedial process of the basipterygium is distinct in most catfishes (Figs. 62a, 63a). However, they are partially incorporated in the basipterygium by a bony lamina in the doradids Acanthodoras, Anduzedoras, Doras, Hassar, Hemidoras stenopeltis, $H$. stubelii, Tenellus leporhinus, $T$. ternetzi, and auchenipterids Ageneiosus, Gelanoglanis, and Tetranematichthys (Figs. 62b, 63b). On the other hand, in the doradids Hemidoras morei, H. morrisi, Ossancora, and Trachydoras (Fig. 62c; Higuchi, 1992: \#109, \#110; Sousa, 2010: \#76), and auchenipterids Auchenipterus, Epapterus, and Pseudepapterus (Fig. 63c; Shelden, 1937: fig. 20), the anteromedial processes are indistinct and incorporated in the basipterygium by bony lamina. This character was coded as inapplicable for the Aspredinidae, which lack the anterior processes of the basipterygium; and as missing data for the auchenipterid Spinipterus.
284. Paired anterolateral processes of basipterygium: 0separated; 1- sutured (CI 1.0, RI 1.0).

Among examined species, a suture between the paired anterolateral processes of the basipterygium is present only in the auchenipterids Auchenipterus, Entomocorus, Epapterus, and Pseudepapterus (Fig. 63c). This character was coded as missing data for the auchenipterid Spinipterus.

285. Lateral process of basipterygium: 0- short, without cartilaginous extensions; 1 - with well-developed cartilaginous extension (CI 0.333, RI 0.846).

Among examined species, only the Heptapteridae, and auchenipterids Asterophysus, Auchenipterus, Centromochlus, Liosomadoras, Pseudauchenipterus, Tocantinsia, Trachelyichthys, Trachelyopterichthys, Trachelyopterus, and Trachycorystes lack a cartilaginous extension on the lateral process of the basipterygium. This character was coded as missing data for the auchenipterids Glanidium, Pseudotatia, and Spinipterus.

286. Shape of posterior process of basipterygium: 0- tapering posteriorly; 1- truncate (CI 1.0, RI 1.0).

The posterior process of the basipterygium is acute, tapering posteriorly, in most catfishes (Figs. 62, 63a-b). However, it is truncate in the auchenipterids Auchenipterus, Entomocorus and Pseudepapterus (Fig. 63c; Akama, 2004: \#121). This character was coded as missing data for the auchenipterids Epapterus and Spinipterus.

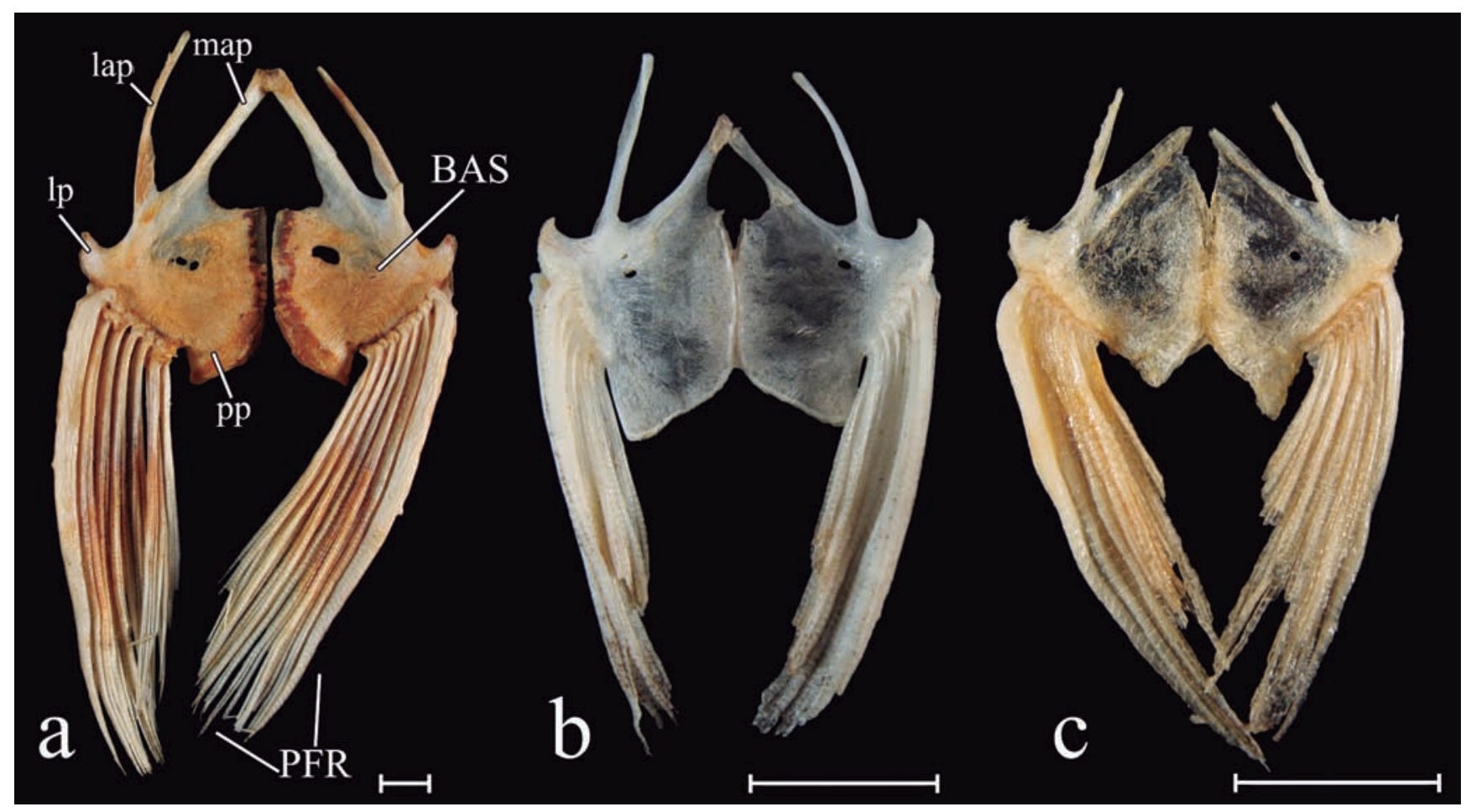

Fig. 62. Pelvic girdle in dorsal view of (a) Lithodoras dorsalis, MZUSP 91562, 450 mm SL; (b) Doras higuchii, MZUSP 101693, 172.0 mm SL; (c) Hemidoras morei, MZUSP 32526, 153.2 mm SL. BAS basipterygium, lap anterolateral process, lp lateral process, map anteromedial process, PFR pelvic-fin rays, pp posterior process. Scale bars equal $10 \mathrm{~mm}$. 


\section{Anal fin}

287. Number of branched anal-fin rays (ordered): 0 - five to eight; 1 - nine to 13; 2- 14 to 31; 3- 32 or more (CI 0.2, RI 0.647).

The number of branched anal-fin rays greatly varies among species of catfishes, but is usually between 9 and 13 (Lundberg, 1970: 101, \#100; Arratia, 1987: 63; Friel, 1994). Among examined species, the exceptions include: Amphiliidae, Aspredinidae, Pseudopimelodidae with five, Malapteruridae with seven, Ictaluridae with 24, Pangasiidae with 32, Siluridae with about 60 , and auchenipterids Asterophysus, Centromochlus, Gelanoglanis, Liosomadoras, Tatia, and Tocantinsia with five to eight, Ageneiosus atronasus, A. brevis, A. piperatus, Auchenipterichthys, Entomocorus, Pseudauchenipterus, Spinipterus, Trachelyopterus, and Trachycorystes with 14 to 31, Auchenipterus, Epapterus, Pseudepapterus, Tetranematichthys, Trachelyichthys, Trachelyopterichthys, and large-sized species of Ageneiosus with 32 to 62 branched anal-fin rays (Ferraris, 1988: \#A2; Walsh, 1990: \#29; Royero, 1999: \#93; Akama, 2004:\#132).

288. Orientation of anal fin in mature males: 0 - normal, ventrally oriented; 1 -oblique relative to body axis, posteriorly oriented (CI 1.0, RI 1.0).

Among examined species the anal fin is oblique relative to the body axis, and posteriorly oriented, only in mature males of the auchenipterids Centromochlinae (Figs. 18a, 38a; Royero, 1999: \#132; Akama, 2004:\#147).
289. Orientation of anal-fin proximal radials in mature males: 0 - perpendicular to long axis of body, interdigitating with hemal spines; 1- oblique to body axis, not interdigitating with hemal spines (CI 1.0, RI 1.0).

The anal-fin proximal radials in mature males of the auchenipterids Centromochlinae are oblique relative to the body axis, and not interdigitating with the corresponding hemal spines (Fig. 64; Ferraris, 1988: \#A5, \#A6; Soares-Porto, 1998: \#28; Akama, 2004: \#133, \#152). In all other examined species, the anal-fin proximal radials in mature males are transversal to long axis of body, interdigitating with the hemal spines.

290. Size of anal fin in mature males: 0 - moderate, length of anterior branched rays more than $10 \%$ of SL; 1 - short, length of anterior branched rays less than $10 \%$ of SL (CI 0.5-1.0, RI 0.0-1.0).

In mature males of the auchenipterids Gelanoglanis and Tatia the anal fin is relatively short, with distance from anal-fin base origin to tip of longest anal-fin ray 5 to $10 \%$ of SL (Fig. 38a; Soares-Porto, 1998: \#27; Soares-Porto et al., 1999). The base of the anal fin in males of Gelanoglanis and Tatia is also extremely short, 1.8 to $8.0 \%$ of SL (Soares-Porto et al., 1999; Sarmento-Soares \& Martins-Pinheiro, 2008: 498). Although both of those characters were treated as exclusive to Tatia (SarmentoSoares \& Martins-Pinheiro, 2008), they are also present in Gelanoglanis, as described by Soares-Porto et al. (1999). The length of the anterior branched anal-fin rays are more than $10 \%$ of SL in mature males of all other examined species.

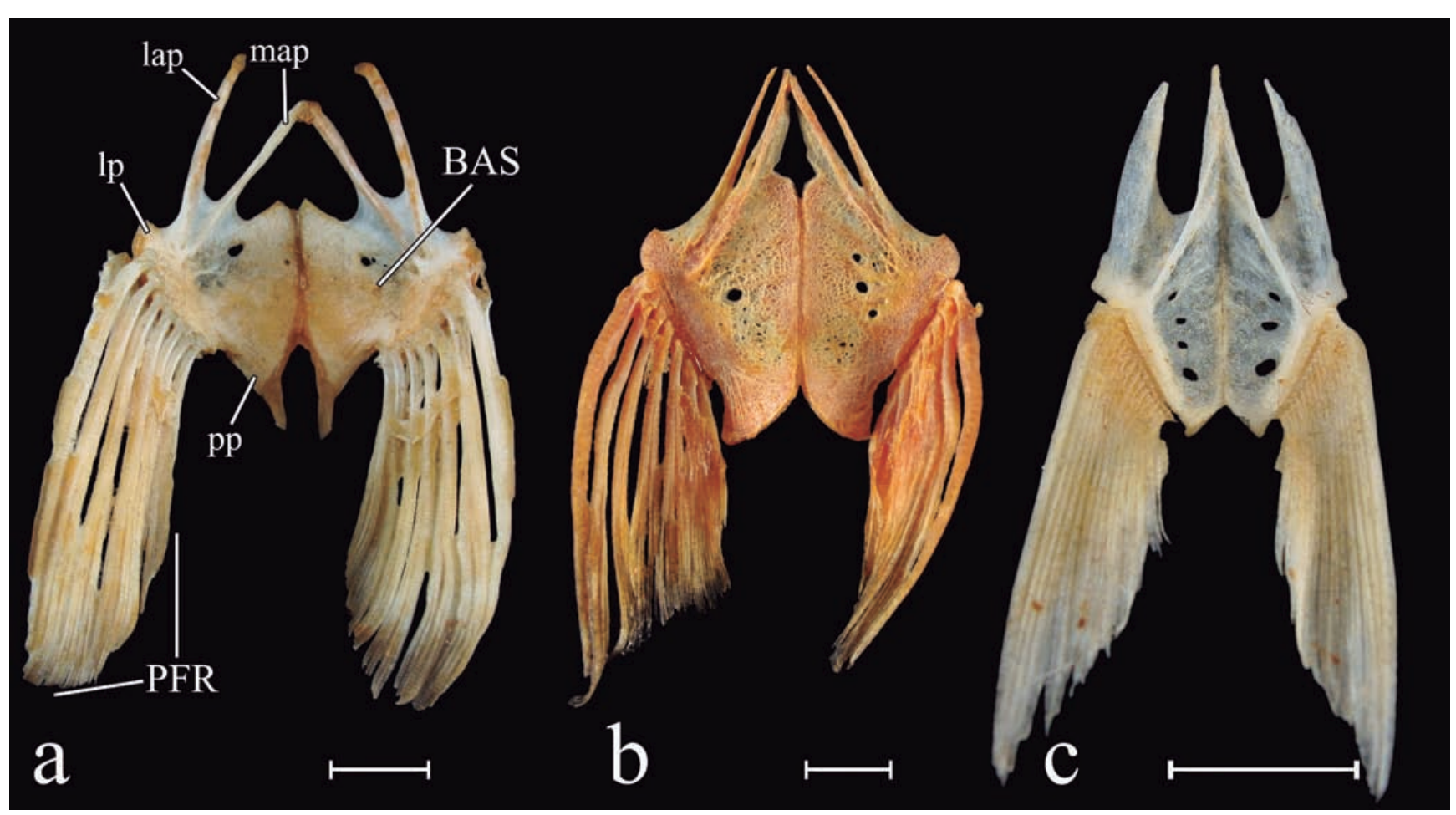

Fig. 63. Pelvic girdle in dorsal view of (a) Tocantinsia piresi, MZUSP 100031, 440 mm SL; (b) Ageneiosus inermis, MZUSP 91661, 333 mm SL; (c) Auchenipterus nuchalis, MZUSP 89728, 141 mm SL. BAS basipterygium, lap anterolateral process, lp lateral process, map anteromedial process, PFR pelvic-fin rays, pp posterior process. Scale bars equal $10 \mathrm{~mm}$. 


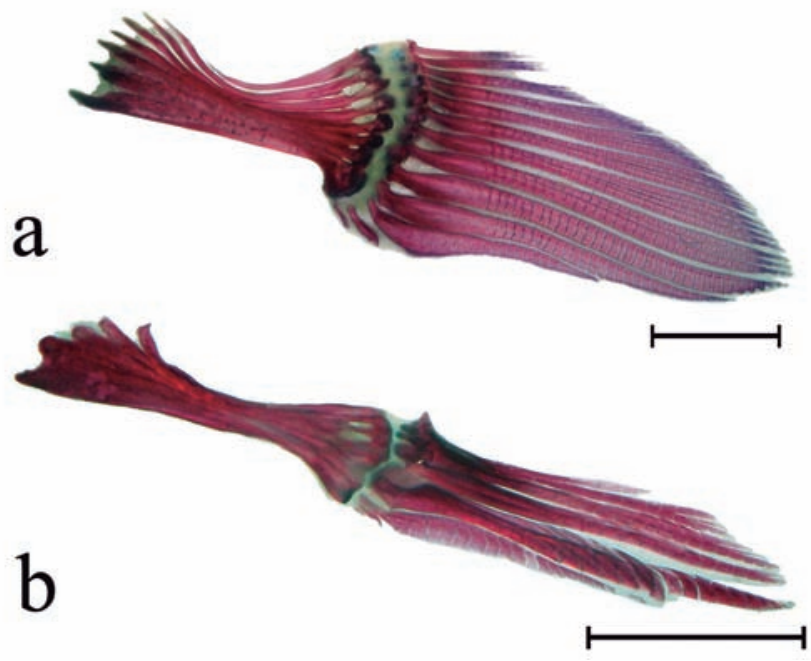

Fig. 64. Anal fin in cleared and stained specimens of mature males of (a) Glanidium melanopterum, MZUSP 51043, 107.9 mm SL; (b) Centromochlus heckelii, MZUSP 49529, 97.4 mm SL.

291. Anal-fin proximal radials in mature males (ordered): 0 separated; 1- partially fused forming a single ossification; 2completely fused together forming a single ossification (CI 1.0, RI 1.0).

In most examined species, the proximal radials are not sutured together in mature males. However, in mature males of most species of the auchenipterid Glanidium (including $G$. melanopterum), the anal-fin proximal radials are partially fused to each other, i.e., the anterior rays are fused and the posterior ones are not (Fig. 64a; Soares-Porto, 1998: \#30; Royero, 1999: \#139; Akama, 2004: \#153). In mature males of the examined species of auchenipterids Centromochlus and Tatia, on the other hand, all anal-fin proximal radials are completely fused together (Fig. 64b; Ferraris, 1988: \#A7; Soares-Porto, 1996: \#30).

292. Shape of posteriormost four or five anal-fin proximal radials: 0- rod-like; 1- laminar (CI 1.0, RI 1.0).

Among examined species, the last four or five anal-fin proximal radials are laminar only in the auchenipterids Auchenipterus, Epapterus, and Pseudepapterus (Ferraris, 1988: \#A8; Akama, 2004: \#134). This character was coded as missing in the auchenipterid Spinipterus.

293. Retrorse spines on anal-fin rays in mature males: 0absent; 1- present (CI and RI inapplicable).

In mature males of some species of the auchenipterid Centromochlus heckelli, there are retrorse spines on the posterolateral margin of the last unbranched and first branched anal-fin rays (Fig. 64b; Ferraris, 1988: \#A9; Soares-Porto, 1998: \#38; Royero, 1999: \#134, \#136; Akama, 2004: \#157). This feature is absent in all other examined species. This character was coded as missing in the auchenipterids Pseudotatia and Spinipterus.
294. Antrorse and retrorse spines on anal-fin rays in mature males: 0- absent; 1 - present (CI and RI inapplicable).

Among examined species, there are antrorse spines on the anterior margin of the last unbranched anal-fin ray, and retrorse spines on the anterior margin of the first branched anal-fin ray only in mature males of auchenipterid Tatia (Ferraris, 1988: \#A11; Soares-Porto, 1998: \#37, \#39; Royero, 1999: \#134, \#135, \#137; Akama, 2004: \#155, \#156). This character was coded as missing data for the auchenipterids Pseudotatia and Spinipterus.

295. Posteriorly directed hook on last unbranched anal-fin ray in mature males: 0 - absent; 1 - present (CI and RI inapplicable).

In mature males of the auchenipterid Auchenipterus, there is a posteriorly directed hook on the last unbranched anal-fin ray (Akama, 2004: \#158). This feature is absent in mature males of all other examined species. This character was coded as missing data for the auchenipterids Pseudotatia and Spinipterus.

296. Spines on lateral face of anal-fin rays: 0- absent; 1 - present (CI and RI inapplicable).

Among examined species, the lateral face of the anal-fin rays bears spines only in the doradid Agamyxis, similarly to the conditions of the pelvic and caudal-fin rays.

297. Shape of first unbranched anal-fin ray: 0- rod-like; 1plate-like (CI and RI inapplicable).

The first unbranched anal-fin ray is modified into an ossified plate only in the doradid Agamyxis. All other examined species have the first unbranched anal-fin ray rod-like.

298. First unbranched anal-fin ray in mature males: 0 segmented; 1- not segmented (CI and RI inapplicable).

In the auchenipterid Tatia (except T. brunnea), the first unbranched anal-fin ray is not segmented (Soares-Porto, 1998: \#33; Sarmento-Soares \& Martins-Pinheiro, 2008: 498). Even though this feature might be present in other auchenipterids, such as for example Centromochlus meridionalis (SarmentoSoares et al., 2013: fig. 5), it is absent in mature males of all other examined species.

299. Size of anterior anal-fin rays in mature males: 0 - small; 1 enlarged (CI 1.0, RI 1.0).

In mature males of the auchenipterids Ageneiosus, Auchenipterichthys, Auchenipterus, Epapterus, Pseudepapterus, Tetranematichthys, Trachelyichthys, Trachelyopterichthys, Trachelyopterus, and Trachycorystes (Akama, 2004: \#148; Royero, 1999: \#131), the anterior analfin rays are enlarged. This feature is absent in mature males of all other examined species. This character was coded as missing data for the auchenipterids Pseudotatia and Spinipterus. 


\section{Caudal fin}

300. Shape of caudal fin (unordered): 0- bifurcated; 1truncated; 2- rounded (CI 0.286, RI 0.444).

The caudal fin is usually bifurcated in catfishes (Figs. 3b$\mathrm{d}, 4,38)$. However, in the Malapteruridae and doradid Acanthodoras, the caudal fin is rounded (Fig. 3a; Higuchi, 1992: \#76; Sousa, 2010: \#82). The caudal fin is truncate in the auchenipterids Ageneiosus inermis, A. polystictus Auchenipterichthys, Spinipterus, Tetranematichthys, Trachelyichthys, Trachelyopterichthys, Trachelyopterus (Ferraris, 1988: \#C1; Walsh, 1990: \#26; Royero, 1999: \#142; Akama, 2004: \#135), and doradids Amblydoras, Astrodoras, Hypodoras, and Physopyxis (Higuchi, 1992: \#74, \#75; Sousa, 2010:\#82).

301. Shape of caudal-fin procurrent rays: 0- rod-like; 1 - platelike(CI 0.25, RI 0.667).

As described by Eigenmann (1925: 293, as "fulcra"), the doradids Agamyxis, Franciscodoras, Platydoras, Orinocodoras, Rhinodoras, and Rhynchodoras have the caudal-fin procurrent rays modified into plates that frame the caudal peduncle dorsally and ventrally (Fig. 65a; Higuchi, 1992: \#79; Birindelli et al., 2007; Sousa, 2010: \#83). As discussed by Birindelli et al. (2007), the first caudal-fin procurrent rays are slightly modified into plates, dorsally, and ventrally, in doradids Anadoras, Astrodoras, Hypodoras, Ossancora fimbriata, and some specimens of Ossancora eigenmanni. The caudal peduncle is covered by plates in Lithodoras; however, those are not homologous with modified procurrent rays. In all other examined species, the caudal-fin procurrent rays are rod-like (Figs. 65b-c, 66).
302. Spines on lateral face of caudal-fin rays: 0- absent; 1present (CI 1.0, RI 1.0).

Among examined species, the lateral faces of the caudalfin rays bear small spines only in the doradids Acanthodoras and Agamyxis (Sousa, 2010: \#85).

303. Type of hypurapophysis (unordered): 0- Type A of Lundberg \& Baskin (1969: fig. 3A); 1- Type B of Lundberg \& Baskin (1969: fig. 3B); 2- Type C of Lundberg \& Baskin (1969: fig. 3C) (CI 0.667, RI 0.667).

According to Lundberg \& Baskin (1969), the primitive condition for the hypurapophysis in catfishes is Type A, which is present in the Diplomystidae, Ictaluridae, Schilbeidae, Pangasiidae, and some Bagridae. The Type B hypurapophysis is present only in the Aspredinidae, Cetopsidae, Claroteidae, and Cranoglanidae. All other taxa have hypurapophysis Type C. The present observations corroborate Walsh (1990: 129), by considering the hypurapophysis of Ageneiosus as Type C, contradicting some authors (Lundberg \& Baskin, 1969; Ferraris, 1988: C7; Akama, 2004: \#141), who considered it to be of Type B. This character was coded as inapplicable for the Nematogenyidae and Siluridae, which have other types of hypurapophysis (see Lundberg \& Baskin, 1969); and as missing data for the auchenipterid Spinipterus.

304. Ventral process of hypurapophysis: 0- absent; 1- present (CI 1.0, RI 1.0).

Among examined species, there is a conspicuous ventral process on the hypurapophysis only in the examined species of auchenipterids Auchenipterus, Centromochlus, Entomocorus, Epapterus, and Pseudepapterus (Fig. 66a;

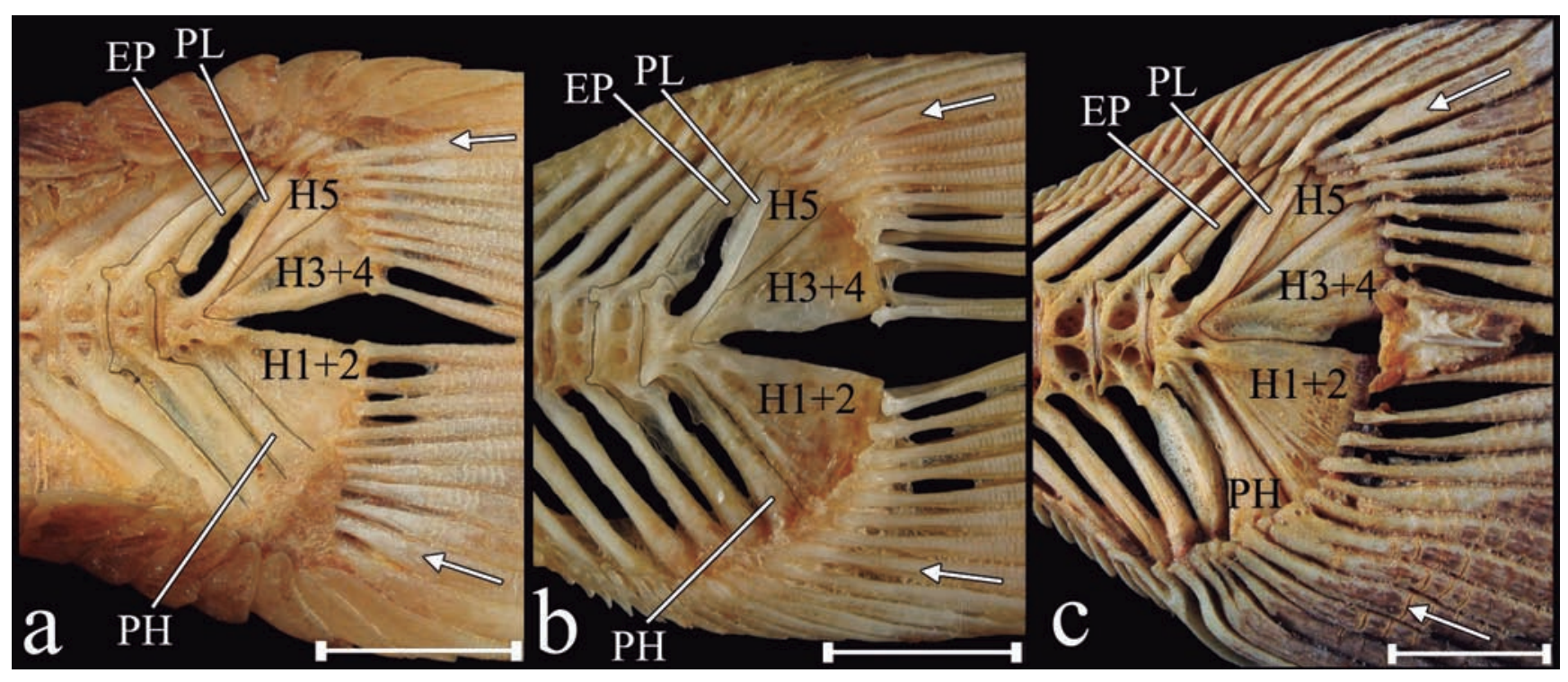

Fig. 65. Caudal fin in lateral view of (a) Orinocodoras eigenmanni, FMNH 105276, 193 mm SL; (b) Wertheimeria maculata, MZUSP 93659, 217 mm SL; (c) Oxydoras niger, MZUSP 91658, 113 mm SL. H1-5 hypurals 1-5, EP epural, PH parhypural, PL pleurostyle. White arrows indicate dorsal and ventralmost principal unbranched caudal-fin rays. Scale bars equal $10 \mathrm{~mm}$. 
Ferraris, 1988: \#C5; Akama, 2004: \#139). This process is extremely elongate in Entomocorus. This character was coded as missing data for the auchenipterid Spinipterus.

305. Number of branched rays in dorsal lobe of caudal fin (ordered): 0- eight; 1 - seven; 2- six; 3- five (CI 0.273, RI 0.2).

Most catfishes have seven branched caudal-fin rays in the dorsal lobe (Figs. 65, 66). Exceptions include the Amphiliidae with five, ariid Genidens, Malapteruridae, and Pseudopimelodidae with six, Diplomystidae with eight (Lundberg \& Baskin, 1969: 11, table 2; Arratia, 1992: \#38; de Pinna, 1993: \#237; Britto, 2002: \#293). Other exceptions include the mochokids Chiloglanis polypogon, Microsynodontis, Mochokiella, and Mochokus brevis with six, M. niloticus and Synodontis contracta with five (Vigliotta, 2008: \#74), and doradid Agamyxis with six branched caudal-fin rays in the dorsal lobe (Sousa, 2010: \#86).

306. Number of branched rays in ventral lobe of caudal fin (ordered): 0- six or seven; 1- eight; 2- nine to 12 (CI 0.182, RI 0.5).

Most catfishes have eight branched caudal-fin rays in the ventral lobe (Figs. 65a,c, 66a,b). Exceptions include the Amphiliidae, Aspredinidae, Malapteruridae, Nematogenyidae, ariid Galeichthys, and mochokids Mochokiella and Mochokus with six or seven branched rays in ventral caudal-fin lobe (Vigliotta, 2008: \#74); doradids Acanthodoras, Agamyxis, Anadoras, Astrodoras, Franciscodoras, Kalyptodoras, Scorpiodoras, and Wertheimeria with seven branched rays (Fig. 65b; Sousa, 2010: \#87), and auchenipterids Spinipterus, Tetranematichthys, Trachelyichthys, Trachelyopterus and some specimens of Trachelyopterichthys with nine to 12 rays (Fig. 66c; Ferraris, : \#C2; Walsh, 1990: \#25; Akama, 2004:\#136). There is intra-specific variation in some cases, such as in the auchenipterids Trachelyopterus galeatus (with nine or ten) and $T$. coriaceus (with ten to 12). This character was coded as polymorphic $(1,2)$ for Trachelyopterichthys.

307. Articulation site of last unbranched caudal-fin ray in ventral lobe: 0- parhypural; 1- hemal spine (CI 0.333, RI 0.6).

In most catfishes, the last unbranched ray in the ventral lobe of the caudal fin is articulated with the parhypural. However, the last unbranched caudal-fin ray in the ventral lobe is articulated with the second to fifth last hemal spine in the auchenipterids Auchenipterichthys, Tetranematichthys, Trachelyichthys, Trachelyopterichthys, and Trachelyopterus (Figs. 66c; Ferraris, 1988: \#C3; Akama, 2004: \#137). This character was coded as missing data for the auchenipterid Spinipterus.

308. Second ural centrum: 0- reduced (Type 1 of de Pinna \& Ng, 2004: 4); 1- well developed (Type 3 of de Pinna \& Ng, 2004: 4) (CI 0.167, RI 0.0).

The second ural centrum is well developed (type 3 of de Pinna \& Ng, 2004: 4) in the auchenipterids Asterophysus (de Pinna \& Ng, 2004: 11) and Entomocorus (Ferraris, 1988: \#C4; Akama, 2004: \#138). The same condition is also present in the Amphiliidae, Aspredinidae, Erethistidae, Mochokidae (Chiloglanis polypogon), Pseudopimelodidae (Pseudopimelodus raninus) and Sisoridae (except Bagarius) (Lundberg \& Baskin, 1969; Britto, 2002: \#291; de Pinna \& Ng, 2004). In all other examined species, the second ural centrum is reduced (Type 1 of de Pinna \& Ng, 2004: 4). This character was coded as missing data for the auchenipterid Spinipterus.

309. Dorsal elements of caudal skeleton (ordered): 0separated; 1 - hypurals 3 and 4 fused, 5 distinct; 2- hypurals 3, 4 and 5 fused (CI 0.333, RI 0.692).

In many catfishes, hypurals 3, 4, and 5 are separate elements (Lundberg \& Baskin, 1969). However, in the

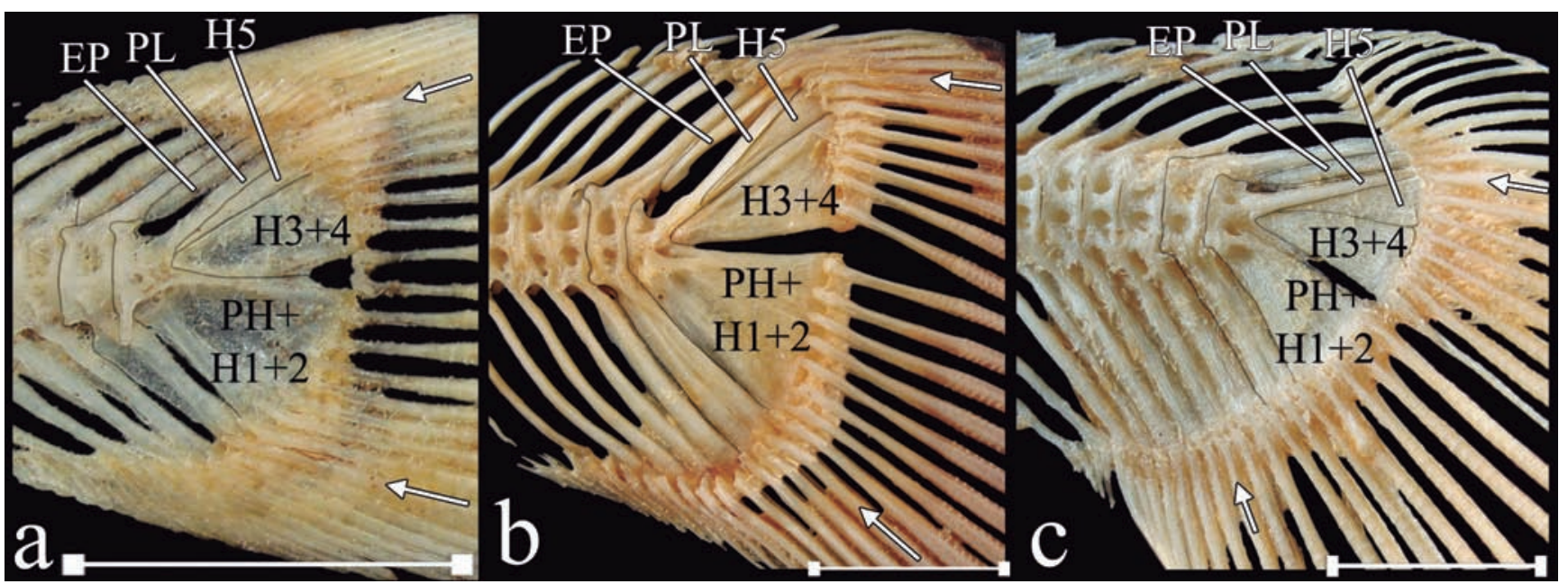

Fig. 66. Caudal fin in lateral view of (a) Centromochlus heckelii, MZUSP 101767, 86.8 mm SL; (b) Trachycorystes trachycorystes, MZUSP 91659, 200 mm SL; (c) Trachelyopterus galeatus, MZUSP 52088, 165 mm SL. H1-5 hypurals 1-5, EP epural, PH parhypural, PL pleurostyle. White arrows indicate dorsal and ventralmost principal unbranched caudal-fin rays, black arrow indicates ventral process of hypurapophysis. Scale bars equal $10 \mathrm{~mm}$. 
Amphiliidae, Ariidae, Auchenipteridae, Doradidae (except Acanthodoras), Heptapteridae, Malapteruridae, and Pseudopimelodidae, hypurals 3 and 4 are fused (hypural 5 is distinct) (Figs. 65, 66). In the Aspredinidae, Claroteidae, Erethistidae, Sisoridae, doradids Acanthodoras and most mochokids (except Atopochilus and Euchilichthys; Vigliotta, 2008: \#72; Sousa, 2010: \#88), hypurals 3, 4 and 5 are fused together. In some cases, as in the doradid Franciscodoras marmoratus (MZUSP 97145, 29.4 mm SL, MZUSP 9380, 180 $\mathrm{mm} \mathrm{SL}$ ), all elements are [or may be] distinct in small juveniles (i.e., $\mathrm{PH}, 1,2,3,4,5)$ but several of them fuse together in larger specimens $(\mathrm{PH}, 1+2,3+4,5)$. This character was coded as missing data for the auchenipterid Spinipterus.

310. Ventral elements of caudal skeleton (ordered): 0separated; 1 - hypurals 1 and 2 fused, parhypural distinct; 2parhypural and hypurals 1 and 2 all fused (CI 0.4, RI 0.93).

In several catfishes, the parhypural and hypurals 1 and 2 are distinct elements (Lundberg \& Baskin, 1969). However, the hypurals 1 and 2 are fused (parhypural distinct) in the Ariidae, Claroteidae, Heptapteridae, Malapteruridae, Pimelodidae, and most species of Doradidae (except Astrodoradinae, Acanthodoras, Agamyxis, and Rhinodoras thomersoni) (Fig. 64) and the parhypural and hypurals 1 and 2 are fused together in the Amphiliidae, Aspredinidae, Auchenipteridae, Erethistidae, Mochokidae (Vigliotta, 2008: \#71), Pseudopimelodidae, Sisoridae, and doradids Astrodoradinae, Acanthodoras, Agamyxis, and Rhinodoras thomersoni (Fig. 65; Sousa, 2010: \#89). This character was coded as missing data for the doradids Centrochir and Megalodoras, and auchenipterid Spinipterus.

\section{Phylogenetic Analysis}

The parsimony analysis of phylogenetic relationships among species of Doradoidea, based on 311 morphological characters and 100 taxa (being 23 taxa of the Auchenipteridae, 57 taxa of the Doradidae, and 20 outgroups), resulted in six equally most parsimonious cladograms of 1079 steps, CI of 0.358 and RI of 0.820 . From the six fundamental trees found, a strict consensus tree was obtained (Figs. 67-70). All character state changes (i.e., synapomorphies, homoplasies and autapomorphies), resulted from ACCTRAN optimization, were listed in the Appendix.

Systematic Account. All suprageneric taxa obtained in the present study are diagnosed and discussed below. In addition, the new genus Tenellus is described and diagnosed.

\section{Doradoidea Bleeker, 1858}

Included taxa. Auchenipteridae and Doradidae.

Diagnosis. The Doradoidea is diagnosed by the following characters: bony suture between exoccipital and neural arch of complex vertebra (\#82: 0>1, exclusive), dorsal surface of epiotic participating in cephalic shield (\#83: 0>1, exclusive), infraorbital 1 strongly connected by lateral ethmoid (\#95: 0>1, exclusive), hyomandibular crest for levator arcus palatini muscle weakly or well developed (\#154: 0>1, reversed in most doradids, and present also in some non-Doradoidea catfishes), subpreopercle present (\#168: 0>1, also present in some non-Doradoidea catfishes), seven to nine branchiostegal rays (\#177: $0>1$, also present in some non-Doradoidea catfishes), transformator process of tripus straight (\#203: 0>1, exclusive), os suspensorium reduced in size (\#204: 0>1, exclusive), Müllerian ramus modified with short thin base and distal flexible disc, latter connected to dorsal face of gas bladder (\#205: 2>3, exclusive), posterior ramus of parapophysis of fourth vertebra absent (\#210: 0>1, exclusive), parapophysis of fifth vertebra reduced in size or eventually absent (\#211: 1>0, reversed in the doradid Leptodoras juruensis and in the auchenipterid Gelanoglanis), anterior ribs articulated to the dorsal face of the parapophysis (\#219: $0>1$, exclusive), proximal end of ribs twisted (\#220: $0>1$, present also the Amphiliidae, Aspredinidae, and Sisoroidea), anterior face of dorsal-fin spine with serrations (\#242: 0>1, reversed in several auchenipterids, in the doradid Anadoras, and present also in some non-Doradoidea catfishes), mesocoracoid absent (\#250: 0>1, also present in some non-Doradoidea catfishes), hypurals 3 and 4 fused, 5 distinct (\#309: 2>1, also present in some other non-Doradoidea catfishes).

\section{Auchenipteridae Bleeker, 1862}

Included taxa. Auchenipterinae and Centromochlinae.

Diagnosis. The Auchenipteridae is diagnosed by the following characters: adipose fin short, thin and teardrop-shaped (\#5: $0>2$, also present in some non-Auchenipteridae catfishes), maxillary barbel moving vertically (\#13: $0>1$, exclusive), suborbital groove present (\#14: 0>1, exclusive), reproduction by insemination (\#43: 0>1, exclusive), posterior testicular lobes modified into hypertrophied storage bags (\#44: 0>1, reversed in Asterophysus, Centromochlus, Glanidium, Tatia, and modified in Ageneiosus and Auchenipterus), urogenital opening at base of first anal-fin rays in males (\#46: 0>1, exclusive), urogenital opening wide in females (\#50: $0>1$, exclusive), posterolateral margin of epiotic participating in the border of cephalic shield (\#84: $0>1$, reversed in Asterophysus and Liosomadoras, present also in some doradids), infraorbital 1 participating in orbital margin (\#97: $0>1$, present also in Astrodoradinae, and in the doradids Acanthodoras, Agamyxis, Lithodoras, and Pterodoras), vertical rows of neuromasts dorsal to lateral line present (\#117: 0>1, reversed in Ageneiosus, Auchenipterus, Entomocorus, Epapterus, Gelanoglanis, Pseudepapterus, Spinipterus, and Tetranematichthys), posterodorsal process of hyomandibula present (\#159: 0>1, reversed in Asterophysus, Auchenipterus, Entomocorus, Epapterus, Gelanoglanis, and Pseudepapterus), suprapreopercle present (\#167: 0>1, reversed in Liosomadoras, present also in some non- 
Auchenipteridae catfishes), first hypobranchial cylindrical (\#191: 0>1, reversed in Auchenipterus, Entomocorus, Epapterus, Glanidium, Psedepapterus, present also in some doradids), first free vertebra eighth (\#217: 1>3, reversed in Gelanoglanis, Pseudepapterus, modified in Auchenipterichthys, Centromochlus, Tocantinsia, Trachelyopterichthys, Trachelyopterus, and Trachycorystes, present also in some non-Auchenipteridae catfishes), lateral process of basipterygium with well-developed cartilaginous extension (\#285: 0>1, reversed in Ageneiosus, Auchenipterus, Entomocorus, Epapterus, Pseudepapterus, Tetranematichthys, present also in some nonAuchenipteridae catfishes), five to eight branched anal-fin rays (\#287: 1>0, modified in most auchenipterids, present also in some non-Auchenipteridae catfishes).

\section{Auchenipterinae Bleeker, 1862}

Euanemini Bleeker, 1858: 39 (see also Bleeker, 1858: 49, 189) [type genus: Euanemus (=Auchenipterus)].

Tracheliopterini Bleeker, 1858: 39 (see also Bleeker, 1858: 49, 250, 257) [type genus: Trachelyopterus].

Pseudauchenipterini Bleeker, 1862 (in Bleeker, 1862-1863): 6 [type genus: Pseudauchenipterus].

Astrophysi (=Asterophysi) Bleeker, 1862 (in Bleeker, 18621863): 7 [type genus: Asterophysus].

Auchenipterini Bleeker, 1862 (in Bleeker, 1862-1863): 14 [type genus: Auchenipterus].

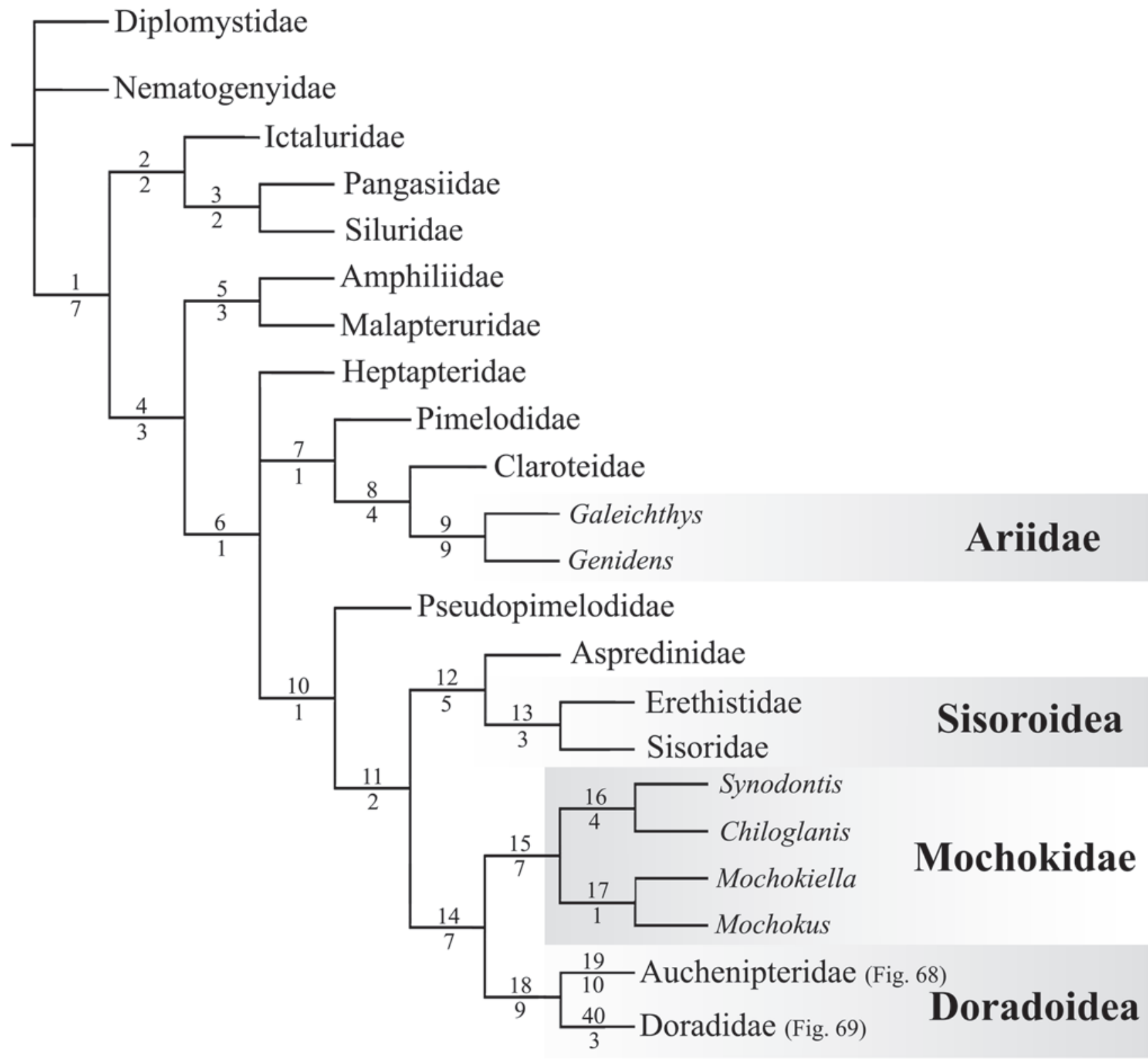

Fig. 67. Part 1: Consensus tree of phylogenetic relationships among higher-level taxa. Numbers of nodes indicated above branches and values for Bremer support indicated below branches. Character state changes (i.e., synapomorphies, autapomorphies, and homoplasis) supporting for each branch listed in Appendix. 
Ageneiosi Bleeker, 1862 (in Bleeker, 1862-1863): 14 [type genus: Ageneiosus].

Trachycorystidae Miranda Ribeiro, 1911: 352 [type genus: Trachycorystes].

Included taxa. Ageneiosus, Asterophysus, Auchenipterichthys, Auchenipterus, Entomocorus, Epapterus, Liosomadoras, Pseudauchenipterus, Pseudepapterus, Pseudotatia, Spinipterus, Tetranematichthys, Tocantinsia, Trachelyichthys, Trachelyopterichthys, Trachelyopterus and Trachycorystes.
Diagnosis. The subfamily Auchenipterinae is diagnosed by the following characters: urogenital opening at the tip of anterior anal-fin rays in males (\#46: 1>2, exclusive), lateral line sinusoidal (\#115: 0>1, reversed in Spinipterus, present also in Centromochlus), accessory cartilage present between third and fourth basibranchials (\#190: $0>1$, reversed in Asterophysus, present also in some non-Auchenipteridae catfishes), six branched pelvic-fin rays (\#276: $0>1$, reversed in Entomocorus, and modified in Asterophysus, Auchenipterichthys, Auchenipterus, Epapterus, Pseudauchenipterus, Pseudepapterus, Trachelyichthys,

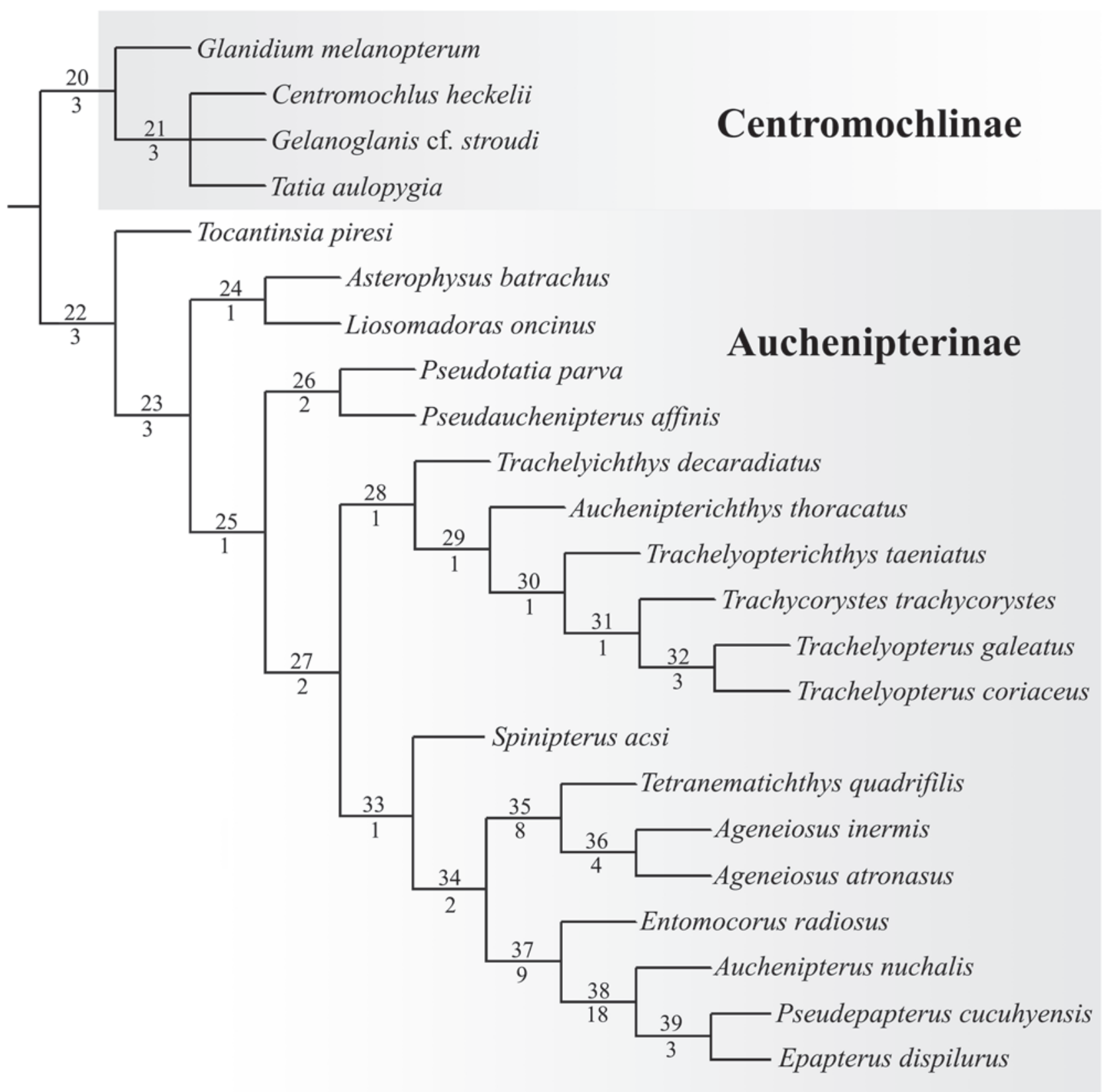

Fig. 68. Part 2: Consensus tree of phylogenetic relationships in Auchenipteridae. Numbers of nodes indicated above branches and values for Bremer support indicated below branches. Character state changes (i.e., synapomorphies, autapomorphies, and homoplasis) for each branch listed in Appendix. 
Trachelyopterichthys, Trachelyopterus, Trachycorystes, present also in some non-Auchenipteridae catfishes).

Remarks. The subfamily Auchenipterinae is considered to be composed of Tocantinsia plus four monophyletic clades (Fig. 68). Clade 1: the Asterophysus/Liosomadoras is supported by three characters, including the frontals not participating in the orbital margin (\#64: 0>1, also present in Auchenipterichthys, Auchenipterus, Epapterus, Pseudepapterus, Trachelyopterichthys, Trachelyopterus and Trachycorystes), epiotic not participating in the border of the cephalic shield (\#84: 1>0, present also in some specimens of Trachycorystes) and spines widespread on the posterior cleithral process (\#268: 1>0, also present in Trachelyopterus porosus, coded as innaplicable for Asterophysus, which lack spines on the posterior cleithral process). Clade 2: the
Pseudachenipterus/Pseudotatia clade is supported by five characters, including a distal vesicle on the distal portion of the anterior anal-fin rays in mature males (\#48: 0>1, exclusive, coded as missing data for Pseudotatia), dorsal face of the lateral ethmoid not participating in the cephalic shield (\#59: $1>0$, also present in Centromochlus heckelii), fenestra between the lateral ethmoid and fontral present (\#60: 0>1, coded as missing data for Pseudotatia), fenestra between frontal and orbitosphenoid present (\#77: 0>1, also present in Centromochlinae), and anterior margin of the pectoral girdle elongate with acute tip (\#249: 0>2, also present in Asterophysus, Centromochlus, Entomocorus, Gelanoglanis, and Tatia). Clade 3: the Trachelyopterus clade, also including Auchenipterichthys, Trachelyichthys, Trachelyopterichthys, and Trachycorystes, is supported by two characters, including eight or more branched rays in the pelvic fin (\#276: 1>3, also

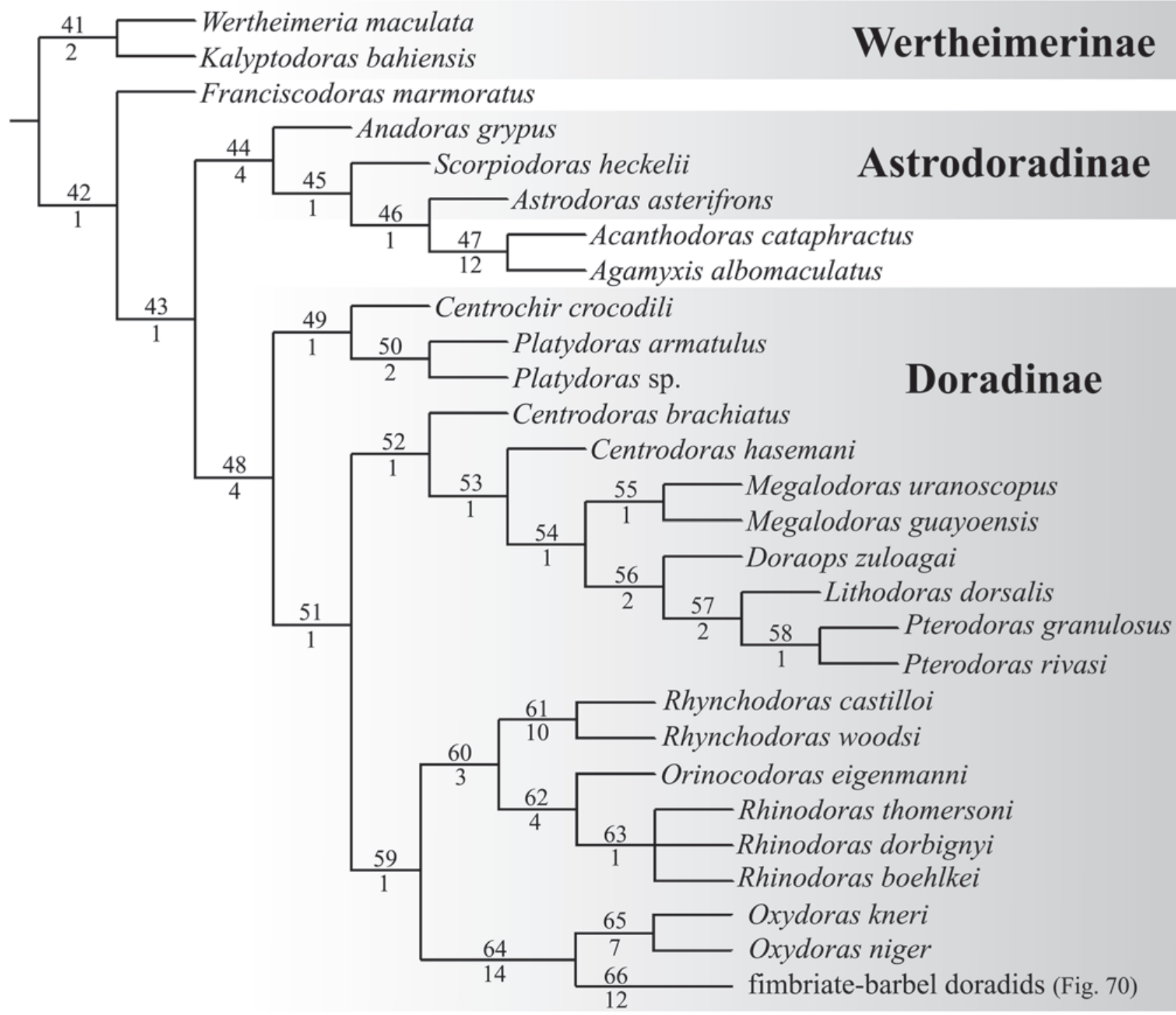

Fig. 69. Part 3: Consensus tree of phylogenetic relationships in Doradidae. Numbers of nodes indicated above branches and values for Bremer support indicated below branches. Character state changes (i.e., synapomorphies, autapomorphies, and homoplasis) for each branch listed in Appendix. 
present in Asterophysus, Auchenipterus, Epapterus, Pseudepapterus, and reversed [i.e., rays equal to seven] in Trachelyopterus), and last unbranched caudal-fin ray in the ventral lobe articulated with hemal spine (\#307: 0>1, also present in Tetranematichthys, reversed in Trachycorystes). Clade 4: the Auchenipterus clade, also including Ageneiosus, Entomocorus, Epapterus, Pseudepapterus, Spinipterus, and Tetranematichthys, is supported by nine characters, including the breeding tubercles on the maxillary barbels (\#25: 0>1, reversed in Ageneiosus, character coded as missing data for Spinipterus), transcapular process at an angle of approximately $45^{\circ}$ relative to body axis (\#92: $0>1$, reversed in Entomocorus, character coded as missing data for Spinipterus), ventral process of infraorbital 1 present (\#98: $0>1$, also present in Centromochlus, character coded as missing data for Spinipterus), ventral rows of neuromasts dorsal to lateral line absent (\#117: 1>0, condition also present in Gelanoglanis), maxilla of mature males elongate (\#134: $0>1$, also present in some species of Trachelyopterus, character coded as missing data for Spinipterus), gill-rakers moderate in size (\#183: 0>1, also present in Glanidium, Centromochlus, Tatia, Tocantinsia, reversed in Auchenipterus, Epapterus, Pseudepapterus, character coded as missing data for Spinipterus), dorsal-fin spine capable of rotating anteriorly (\#241: 0>1, also present in Liosomadoras, and in some species of Trachelyopterus, character coded as missing data for Spinipterus), anteromedial process of basipterygium partially or completely united to basipterygium (\#283: 0>1, also present Gelanoglanis, reversed in Entomocorus, character coded as missing data for Spinipterus), lateral process of basipterygium short (\#285: 1>0, also present in Auchenipterichthys, Gelanoglanis, Tatia, character coded as missing data for Spinipterus).

\section{Centromochlinae Bleeker, 1862}

Centromochli Bleeker, 1862 (in Bleeker, 1862-1863): 7 [type genus: Centromochlus].

Included taxa. Centromochlus, Gelanoglanis, Glanidium, and Tatia.

Diagnosis. The Centromochlinae is diagnosed by the following characters: fenestra present between frontal and orbitosphenoid (\#77: 0>1, also present in Pseudauchenipterus and Pseudotatia), four to six branchiostegal rays (\#177: 1>0, present also in some non-Auchenipteridae catfishes), five branched dorsal-fin rays (\#237: 0>1, also present in Entomocorus, Pseudepapterus, Spinipterus, Trachelyopterus, Trachycorystes, and some nonAuchenipteridae catfishes), posterior cleithral process small (\#265: 2>1, also present in Tetranematichthys, Trachelyopterus galeatus, and T. insignis, and some nonAuchenipteridae catfishes), anal fin oblique relative to the body axis in mature males (\#288: 0>1, exclusive), anal-fin proximal radials oblique relative to the body axis in mature males and not interdigitated with hemal spines (\#289: 0>1, exclusive), anal-fin proximal radials partially or completely fused together forming a single ossification in mature males (\#291: 0>1, exclusive).

\section{Doradidae Bleeker, 1858}

Included taxa. Franciscodoras, Acanthodoras, Agamyxis, Astrodoradinae, Doradinae, and Wertheimerinae.

Diagnosis. The Doradidae is diagnosed by the following characters: midlateral scutes present (\#118: 0>1, exclusive), coronomeckelian bone connected to dentary (\#137: 0>1, reversed in Astrodoradinae, Acanthodoras, Agamyxis, Centrochir, Centrodoras, Doraops, Lithodoras, Megalodoras, Platydoras [except Platydoras sp.], and Pterodoras), ligament present between Müllerian ramus and lateral line (212: 0>1, exclusive), infranuchal ligament between posterior nuchal plate and the first rib ossified (\#213: 1>2, exclusive), first free vertebra sixth (\#217: 2>1, present also in other non-Doradidae catfishes), pectoral-fin spine locking foramen absent (\#253: 0>1, foramen absent also in some nonDoradidae catfishes), six or seven branched rays in the ventral lobe of the caudal fin (\#306: 1>0, reversed back to state 1 in Doradinae).

\section{Wertheimerinae, new subfamily}

Included taxa. Kalyptodoras and Wertheimeria [type genus].

Diagnosis. The subfamily Wertheimerinae is diagnosed by the following characters: well-developed hyomandibular crest for levator arcus palatini muscle (\#154: 1>2, exclusive), hyomandibula articulated with cranium only via sphenotic (\#162: 1>2, also present in Acanthodoras and Agamyxis), 12 or more ribs (\#221: 1>2, also present in Centrodoras, Doraops, Lithodoras, Megalodoras, Oxydoras, and Pterodoras).

Remarks. According to molecular data published by Arce et al. (2013), Franciscodoras should also be included in this subfamily as sister to Kalyptodoras. However, the present analysis recovered Franciscodoras as sister to all doradids, except Wertheimeria and Kalyptodoras. Due to the existing conflict of hypotheses regarding the phylogenetic position of Franciscodoras, the latter is herein considered as incertae sedis in Doradidae.

\section{Astrodoradinae Higuchi, Birindelli, Sousa \& Britski, 2007}

Astrodoradinae Higuchi, Birindelli, Sousa \& Britski, 2007: 33 [type genus: Astrodoras].

Included taxa. Amblydoras, Anadoras, Astrodoras, Hypodoras, Physopyxis, and Scorpiodoras. 
Diagnosis. The subfamily Astrodoradinae is diagnosed by the following characters: adipose fin short, thin and teardropshaped (\#5: 1>2, also present in Acanthodoras, Agamyxis, Anduzedoras, Doras, Hassar, Hemidoras, Leptodoras, Nemadoras, Ossancora, Tenellus, and Trachydoras, and in some non-Doradidae catfishes), posterior process of epiotic mainly ossified (\#85: 1>2, also present in Pterodoras, Rhynchodoras and fimbriate-barbel doradids, and in some non-Doradidae catfishes), infraorbital 1 participating in orbital margin (\#97: 0>1, present also in Acanthodoras, Agamyxis, Lithodoras, and Pterodoras, and in some non-Doradidae catfishes), posterior cleithral process with spines arranged in one main row accompanied by secondary rows (\#268: 1>2, also present in Acanthodoras), ventroposterior margin of coracoid thick, visually exposed (\#272: $0>1$, also present in Acanthodoras, Agamyxis, Hemidoras, Megalodoras, Ossancora, and Trachydoras paraguayensis and $T$. steindachneri, and in some non-Doradidae catfishes).

Remarks. The results of the present analysis indicate the inclusion of Acanthodoras and Agamyxis in the Astrodoradinae. However, since these findings contradicts

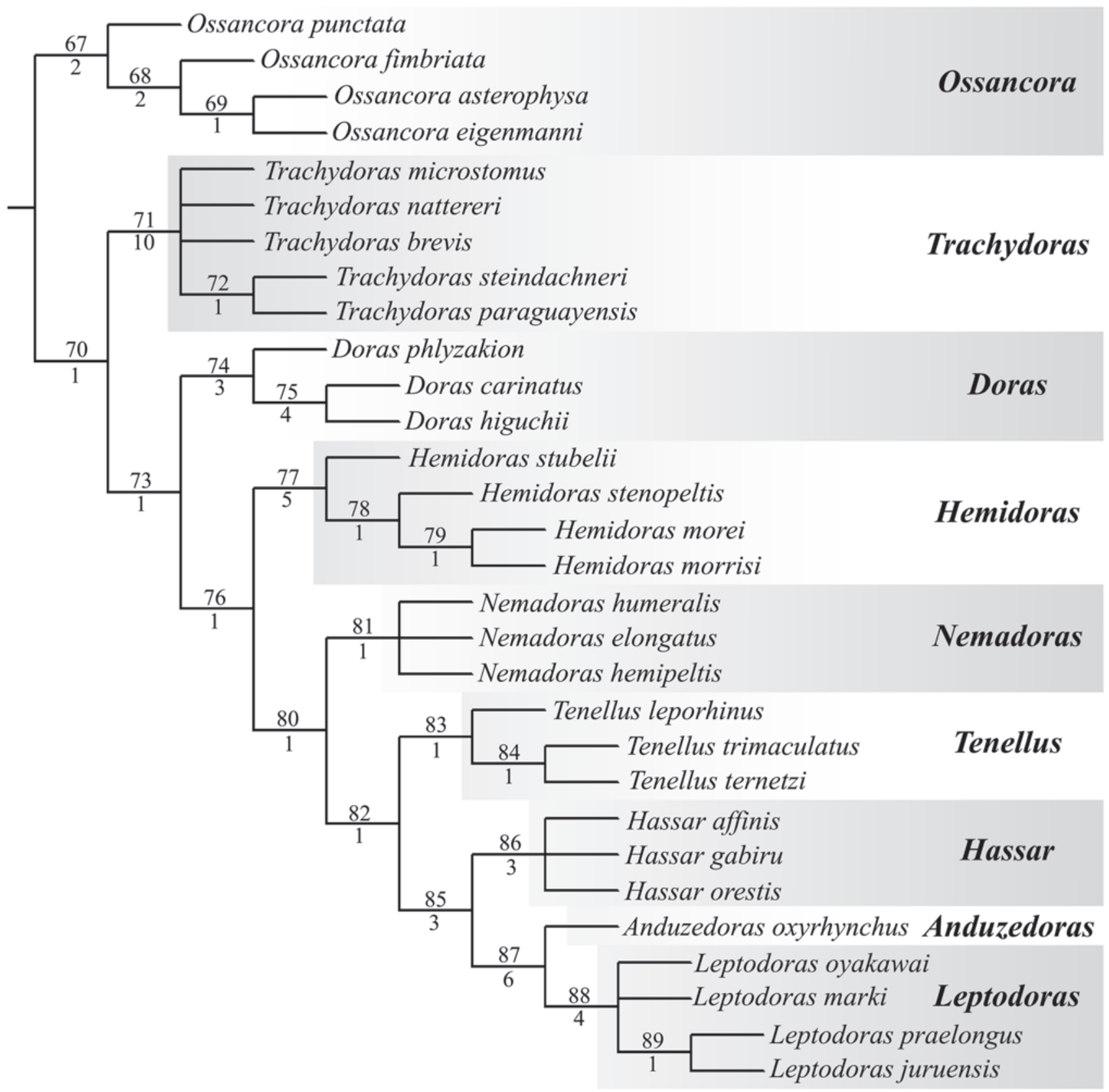

Fig. 70. Part 4: Consensus tree of phylogenetic relationships in the clade that includes the fimbriate-barbel doradids. Numbers of nodes indicated above branches and values for Bremer support indicated below branches. Character state changes (i.e., synapomorphies, autapomorphies, and homoplasis) for each branch listed in Appendix. 
the results obtained by Higuchi (1992), Higuchi et al. (2007), Moyer et al. (2004) and Arce et al., (2013), it is yet premature to transfer these two taxa into Astrodoradinae. These two genera are herein considered as incertae sedis in Doradidae, until more data are available to determine their phylogenetic position. The Diagnosis presented herein for Astrodoradinae includes all characters supporting the clade that comprises all examined species of Astrodoradinae plus Acanthodoras and Agamyxis.

\section{Doradinae Bleeker, 1858}

Doradini Bleeker, 1858: 39 (see also Bleeker, 1858: 48-52) [type genus Doras].

Included taxa. Anduzedoras, Centrochir, Centrodoras, Doraops, Doras, Hassar, Hemidoras, Leptodoras, Lithodoras, Megalodoras, Nemadoras, Orinocodoras, Ossancora, Oxydoras, Platydoras, Pterodoras, Rhinodoras, Rhynchodoras, Tenellus, and Trachydoras.

Diagnosis. The subfamily Doradinae is diagnosed by the following characters: tips of terminal diverticula of the gas bladder ditally divergent (\#36: 0>1, present only in Doras zuanoni, Ossancora punctata, and Trachydoras, coded as missing data for the remaining species of Doradinae, which lack terminal diverticula), first free vertebrae eighth or nineth (\#217: 1>3, modified in Doraops, Lithodoras, Megalodoras, Pterodoras, and also present in some non-Doradidae catfishes), serrations present on the posterior face of the dorsal-fin spine (\#245: 0>1, reserved in some species of Leptodoras, present also in some non-Doradidae catfishes), transverse coracoid crest between adductor superficialis and arrector ventralis muscles (\#274: 0>1, reserved in Doraops, Lithodoras, Oxydoras, Pterodoras, and fimbriate-barbel doradids [except Hemidoras morrisi, and Ossancora fimbriata], also present in Acanthodoras), eight branched rays in the ventral lobe of the caudal fin (\#306: 0>1, also present in some non-Doradidae catfishes), hypurals 1 and 2 fused, parahypural distinct (\#310: 2>1, reversed in Rhinodoras thomersoni, present also in Franciscodoras, Kalyptodoras, and Werthemeria).

Remarks. The present analysis did not recover Centrodoras as monophyletic, however, additional study including yet undescribed species of Centrodoras (Sabaj Pérez, pers. comm.) is necessary to establish the status of the genus.

Two major changes in the classification of Doradidae were made based on the present hypothesis of relationships among species of Doradinae: description of Tenellus as a new genus, and inclusion of the species previously placed in Opsodoras Eigenmann, 1925 within an expanded Hemidoras Bleeker, 1858. Hemidoras was defined by Eigenmann (1925), and subsequently followed by other authors, as comprising two species, $H$. stenopeltis and $H$. morrisi, both sharing dermal scutes between dorsal and adipose fins (\#34). However, other characters analyzed herein indicate that Hemidoras morrisi is closely related to Opsodoras morei (now Hemidoras morei), a hypothesis corroborated by the similarity in the overall morphology of both species. Noteworthy to say, some specimens of Hemidoras morei (including the holotype, NMW 45433) have a single dermal plate between dorsal and adipose fins, a partial representation of the feature formerly used to distinguish Hemidoras from Opsodoras.

As discussed by Ferraris (2007: 164), the suprageneric names Centrochirinae, Hemidoradinae, and Lithodoradinae were proposed by Fowler (1951: 3) in a manner that made the names available when published, but the names were rendered unavailable in 1961 by Art. 13 of the Second Edition of the Code (ICZN, 1961). The names apparently remain unavailable, despite Art. 13.2.1 of the current version of the Code (ICZN, 1999), because they were treated as unavailable in Ferraris \& de Pinna (1999: 8).

Within Doradinae, four major monophyletic groups were recovered in the present (Fig. 69). Clade 1: the Platydoras clade also includes Centrochir and is supported by two characters: a distinct dark longitudinal stripe on the middle of each caudal-fin lobe (\#1: 0>1) (\#1: $0>1$, also present in Anadoras, Orinocodoras, Tenellus, and most Leptodoras), and the secondary chamber of the gas bladder formed by a single posterior chamber, thus without an inner septum (\#38: $0>1$, also present in Doras and Oxydoras, coded as missing data for Centrochir and Platydoras sp., which lack the secondary chamber). Clade 2: the Pterodoras clade (or largedoradids clade) also includes Centrodoras, Doraops, Lithodoras, and Megalodoras and is supported by two characters: large diverticula present on the main bladder and on the secondary chamber of the gas bladder (\#41: 1>2, exclusive), 12 or more ribs (\#221: 1>2, also present in Kalyptodoras, Oxydoras, and Wertheimeria). Clade 3: the Rhinodoras clade also includes Orinocodoras and Rhynchodoras and is supported by five characters: five or six pores on the mandibular canal (\#113: 1>2, also present in Astrodoradinae, Centrochir, Franciscodoras, Kalyptodoras, Lithodoras, Platydoras, Pterodoras, and Wertheimeria, coded as missing data for Rhynchodoras), posterior limit of autopalatine approximately at vertical through the middle of orbit (\#149: 0>1, exclusive), hyomandibular crest for Aw section of the adductor mandibulae muscle present (\#156: $0>1$, exclusive), posterior cleithral process triangular (\#266: $0>1$, exclusive), procurrent rays of the caudal fin plate-like (\#301: 0>1, also present in Agamyxis, Francisodoras and Platydoras). Clade 4: the Doras/Oxydoras clade also includes Anduzedoras, Hassar, Hemidoras, Leptodoras, Nemadoras, Ossancora, Tenellus, and Trachydoras, and is supported by 18 characters, including among others: mesethmoid medially dilated in the shape of an arrow (\#52: $0>2$, exclusive), anteroventral keel of mesethmoid present (\#55: 0>1, exclusive), premaxilla conical with a dorsal apex, depth distinctly greater than width (\#125: 0>1, exclusive), ventral hypohyal quadrangular, length and width approximately equal (\#172: $0>1$, exclusive), conspicuous accessory lamellae on the medial 

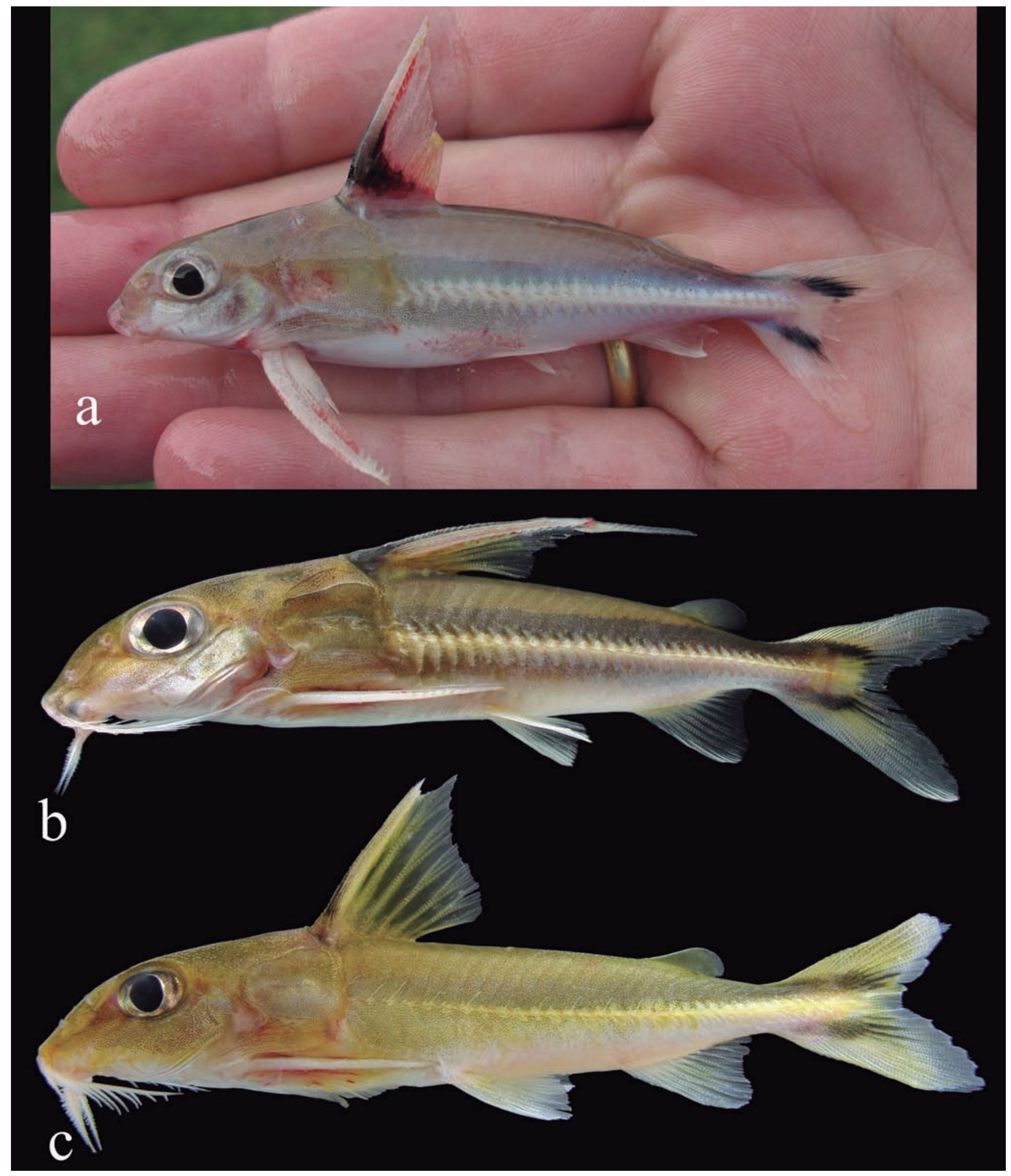

Fig. 71. Tenellus trimaculatus (a), AUM uncatalogued, approximately 90 mm SL, río Orinoco, Puerto Ayacucho, Venezuela; (b) Tenellus ternetzi, MZUSP 103245, 84.5 mm SL, rio Jari, Monte Dourado, Pará State; (c) Tenellus leporhinus, MZUSP 96596, approximately $80 \mathrm{~mm}$ SL, rio Teles Pires, Peixoto de Azevedo, Mato Grosso, photo by Mark Sabaj Pérez. All photographed live. 
face of the ceratobranchials (\#179: 0>1, reversed in Trachydoras), conspicuous accessory lamellae on the medial face of the epibranchials (\#180: 0>1, reversed in Trachydoras), ventral process of fourth basibranchial elongate (\#188: $0>1$, exclusive), pharyngobranchial tooth plate elongate, length about twice width (\#199: 0>1, exclusive), anterior margin of pectoral girdle anteriorly elongate with truncate or acute tip (\#249: 0>1, reversed in Ossancora, Trachydoras, and some species of Leptodoras), dorsoposterior border of coracoid extremely elevated dorsally (\#271: 0>1, exclusive). The Doras/ Oxydoras clade includes the Doras clade, which is herein recognized as composed by the fimbriate-barbel doradids, the most well supported species group of the family with 17 characters, three of them exclusive (see Appendix).

\section{Tenellus, new genus}

Fig. 71

Type species. Oxydoras trimaculatus Boulenger, 1898: 422, pl. 40 (fig. 1). Rio Jurua, an affluent of the Amazon, Brazil.

Included taxa. Tenellus trimaculatus (Boulenger, 1898), new combination (Fig. 71a); Tenellus ternetzi (Eigenmann, 1925), new combination (Fig. 71b); Tenellus leporhinus (Eigenmann, 1912), new combination (Fig. 71c).

Diagnosis. Tenellus is diagnosed by a single character state change: a distinct dark longitudinal stripe on middle of each lobe of the caudal fin (\#1: 0>1, also present in Anadoras, Centrochir, Orinocodoras, Platydoras, and most Leptodoras). In addition, Tenellus is distinguished from other doradids by the following combination of characters: welldeveloped adipose eyelid (\#2: state 1, vs. weakly developed in all doradids except Anduzedoras, Hassar, and some species of Leptodoras), large posterior cranial fontanel (\#58: state 0 , $v$ s. reduced to a small opening in Nemadoras elongatus, $N$. humeralis, and Oxydoras, or completely occluded in all other doradids, except Anduzedoras, Hassar, Leptodoras, Nemadoras hemipeltis, and Trachydoras), sphenotic with lateral process (\#62: state 1, vs. sphenotic without lateral process in all doradids except Anduzedoras, Doras, Hassar, and Leptodoras), posterior process of epiotic connected via ligament to posterior nuchal plate (\#86: state 0, vs. connected via bony suture in Doras carinatus, D. micropoeus, $D$. higuchii, Hassar, Anduzedoras, and Leptodoras), infraorbital 1 with relatively small anterior portion (\#100: state 0, vs. anterior portion relatively large in Doras carinatus, $D$. micropoeus, D. higuchii, Hassar, Anduzedoras, and Leptodoras), ceratohyal with large anterior process sutured to hypohyal (\#174: state 2, vs. process small or absent in most doradids, except Hemidoras, Nemadoras, and Oxydoras), gillrakers present on first two gill arches (\#181: state 1, vs. absent in Trachydoras and some species of Leptodoras).

Etymology. Tenellus comes from the Latin tener, meaning delicate, in the diminutive form, tenellus, in reference to the delicate appearance of the species included in the new genus.

Remarks. Within Tenellus (Fig. 71), T. ternetzi and T. trimaculatus are considered sister taxa by sharing the loss of anterior nuchal plate (\#228: 0>1). Tenellus leporhinus is readily distinguished from congeners by having midlateral scutes weakly developed on middle of body (\#118: 2>1). Tenellus trimaculatus is distinguished from $T$. ternetzi by having welldeveloped bony lamina between internal process and basipterygium (\#283: 1>0), and dark blotch on base of anteriormost dorsal-fin rays, including dorsal-fin spine but excluding spinelet (vs. dark blotch on spinelet but absent on dorsal-fin anteriormost rays).

\section{Discussion}

Monophyly of Doradoidea and relationships with other catfishes. The monophyly of the Doradoidea was recovered in the present analysis, corroborating previous studies based on both morphological (Ferraris, 1988; Mo, 1991; Lundberg, 1993; de Pinna, 1993; Royero, 1999; Britto, 2002; Diogo, 2004; Vigliotta, 2008) and molecular characters (Hardman, 2005; Sullivan et al., 2006, 2008; Arce et al., 2013). Herein, the monophyly of Doradoidea is supported by 16 characters, seven of them exclusive (see Systematic Account and Fig. 67).

The present analysis recovered Doradoidea sister to the African family Mochokidae, corroborating most previous phylogenetic studies based on morphological data (Ferraris, 1988; Mo, 1991; Lundberg, 1993; de Pinna, 1993; Royero, 1999; Britto, 2002; Diogo, 2004; Vigliotta, 2008), but contradicting recent analyses based on molecular data (Hardman, 2005; Sullivan et al., 2006, 2008; Arce et al., 2013). The monophyly of Doradoidea plus Mochokidae is extremely well supported by morphological data, including 13 characters, five of them exclusive (see Fig. 67 and Appendix).

Some characteristics, treated as synapomorphies for Doradoidea plus Mochokidae previously by other authors, were revealed to be complex structures that encompass distinct characters, some synapomorphic and others convergent. This is the case of the elastic spring apparatus, a complex structure that comprises the Müllerian ramus, with different shapes according to catfish families, and the protractor muscle of the Müllerian ramus, with distinct sites of origin and insertion. On the other hand, some characters that are herein considered synapomorphies for Doradoidea plus Mochokidae were previously treated as symplesiomorphies for catfishes. This is the case of the infranuchal ligament, previously considered to be present in catfishes of many other families.

The present study recovered the Doradoidea plus Mochokidae as closely related to the Sisoroidea plus Aspredinidae based on 13 characters. The Sisoroidea was herein represented by the Aspredinidae, Erethistidae, and Sisoridae, but it also includes the Akysidae, Amblicipitidae (de Pinna, 1996, 1998; Lundberg et al., 2014). One of the 
characters supporting the clade Sisoroidea plus Aspredinidae, Mochokidae and Doradoidea, the elongate processes of the dorsal-fin spinelet (\#236: 0>1), is an exclusive feature among catfishes, present only in the Akysidae, Amblicipitidae, Auchenipteridae, Erethistidae, and Doradidae. This feature cannot be verified in the Aspredinidae and Sisoridae, because these taxa lack the dorsal-fin spinelet. The close relationship between Sisoroidea plus Aspredinidae and Doradoidea plus Mochokidae, represents a new and interesting hypothesis that should be tested in future studies. It is noteworthy to note that the molecular data support a close relationship between Aspredinidae and Doradoidea (Sullivan et al., 2006, 2008), i.e., part of the clade recovered herein.

Monophyly of and relationships within Auchenipteridae. The Auchenipteridae is herein recovered as monophyletic, corroborating previous studies (Britski, 1972; Ferraris, 1988; Royero, 1999; Akama, 2004). The monophyly of the family is supported by 16 characters, four of them exclusive (see Systematic Account). Almost all of these characters are related to sexually dimorphic features associated with reproduction by insemination (exclusive to auchenipterids among catfishes).

The Auchenipteridae is considered to be composed of two monophyletic clades: the Centromochlinae and Auchenipterinae. This result corroborates most previous studies (Ferraris, 1988; Soares-Porto, 1998; Akama, 2004). Nevertheless, it contradicts Britski (1972) and Walsh (1990) by considering the former Ageneiosidae as a clade nested well within the Auchenipterinae, and Royero (1999) for considering the clade composed of Auchenipterus, Entomocorus, Epapterus, and Pseudepapterus also deeply nested within the Auchenipterinae, sister to the Ageneiosus clade, instead of sister to all other auchenipterids.

In the present study, the most well supported clades within the Auchenipteridae were the Centromochlinae, with seven characters (three of them exclusive), and all clades inside the clade including Ageneiosus, Auchenipterus, Entomocorus, Epapterus, Pseudepapterus, and Tetranematichthys, supported by up to 22 characters per ramus. It is interesting to note that Entomocorus is a key taxon for having many apomorphic features shared only with Auchenipterus, Epapterus, and Pseudepapterus, but, at the same time, having some plesiomorphic features, shared only with basal auchenipterids. This complex combination of character states may have been responsible for the whole clade associated with Entomocorus to assume a more basal position within auchenipterids in Royero's (1999) phylogenetic analysis.

The monophyly of the clade composed of Ageneiosus, Auchenipterus, Entomocorus, Epapterus, Pseudepapterus, and Tetranematichthys, corroborates the finding of Ferraris (1988) and Akama (2004). Similarly, the monophyly of the clade composed of Auchenipterichthys, Trachelyichthys, Trachelyopterichthys, Trachelyopterus, and Trachycorystes corroborates the findings of Britski (1972) and, at least partially, the results of other authors (Ferraris, 1988; Royero,
1999; Akama, 2004).

Spinipterus acsi is hypothesized as closely related to the clade containing Ageneiosus, Auchenipterus, Entomocorus, Epapterus, Pseudepapterus, and Tetranematichthys. However, since the phylogenetic position of Spinipterus acsi was inferred based exclusively on the data of a single immature male provided in the description of the species (Akama \& Ferraris, 2011), the present hypothesis is at best tentative. Only the study of more specimens of Spinipterus, including fully mature males, will confirm the result obtained herein.

Monophyly of and relationship within Doradidae. The Doradidae is recovered as monophyletic, corroborating Higuchi (1992), Moyer et al. (2004) and Arce et al. (2013). The monophyly of the family is supported by seven characters, two of them exclusive (see Systematic Account and Fig. 67). Although other authors (e.g., Sörensen, 1895; Ladich, 2001) already had mentioned one of these exclusive characters, the ligament between the Müllerian ramus and the lateral line, they have never treated it as a synapomorphy for the whole family. This feature is revealed to be an exclusive character present in all examined doradids. Other synapomorphies include the ossification of the lateral-line tubules as scutes, a feature noticed in every study of the family since Linnaeus (1766); and the presence of the infranuchal scute, also previously reported (e.g., Ferraris, 1988; Higuchi, 1992; Royero, 1999; Akama, 2004).

In the present analysis, Wertheimeria, Kalyptodoras, and Franciscodoras are considered to be at the base of the cladogram of the Doradidae. That hypothesis partially corroborates Higuchi's (1992) results by considering Wertheimeria and Franciscodoras as basal taxa, but differs by considering Kalyptodoras sister to Wertheimeria. That sister-group relationship is interesting because those two taxa are the only ones inhabiting small coastal drainages of eastern Brazil (Ribeiro, 2006), where some relatively old taxa are known (e.g., Copionodontinae, Delturinae). The sistergroup relationships between Wertheimeria and Kalyptodoras was already speculated by Higuchi et al. (1990) in their description of Kalyptodoras bahiensis, and Vono \& Birindelli (2007) in their study of Wertheimeria. Higuchi's (1992) analysis failed to recognize this sister-group relationship because no specimens of Kalyptodoras properly prepared for osteological studies were available at the time. Higuchi’s (1992) analysis coded the characters for Kalyptodoras based on a single alcohol-preserved specimen (paratype) with its belly cut open and gas bladder removed. As a result, important characters, such as the first free vertebra, were miscoded by Higuchi (1992). Arce et al. (2013) alternatively recovered Franciscodoras as part of the clade composed by Wertheimeria and Kalyptodoras. The conflict between the two hypotheses (Arce et al.'s and the present) is interesting and deserves further investigation.

The genera Agamyxis and Acanthodoras were recovered as sister taxa and deeply nested within the Astrodoradinae in the present analysis, a result that corroborates the previous 
findings of Birindelli (2010) and Sousa (2010). However, this hypothesis contradictes the findings of Higuchi (1992) and the limits of the Astrodoradinae according to Higuchi et al. (2007), which did not include Acanthodoras and Agamxis. Based on molecular data, Moyer et al. (2004) and Arce et al. (2013) recovered Acanthodoras as sister to all doradids, except the Astrodoradinae. In their analyses, Agamyxis was recovered as sister to all doradids except the Astrodoradinae and Acanthodoras (and the Wertheimeria clade in Arce et al., 2013). This conflict in the hypothesis of relationships concerning Acanthodoras and Agamyxis is still a matter of debate and should be focused in future studies.

Centrochir and Platydoras are very similar in overall body shape and external morphology, and it is no surprise that they are closely related in the present study. The present results corroborate recently analyses based on morphological and molecular data (Sousa, 2010; Arce et al., 2013; respectively). Nevertheless, in Higuchi's (1992) analysis, Platydoras was considered to be closely related to Kalyptodoras, Acanthodoras and Agamyxis, whereas Centrochir was recovered with Centrodoras, Doraops, Lithodoras, Megalodoras, and Pterodoras.

The present study proposed a new arrangement for the Doradinae, a group supported by six characters. This new arrangement corroborates the findings of previous studies based on morphology (Higuchi, 1992) and only partially those based on molecular data, as Moyer et al. (2004) included Agamyxis in Doradinae, and Arce et al., (2013) included Platydoras and Centrochir in Doradinae.

Within Doradinae, the clade composed by Orinocodoras, Rhinodoras, and Rhynchodoras was herein recovered as monophyletic corroborating previous studies based on morphology (Higuchi, 1992; Birindelli et al., 2007) and molecular data (Moyer et al., 2004; Arce et al., 2013). On the other hand the monophyly of the clade composed by the large doradids (i.e., Centrodoras, Doraops, Lithodoras, Megalodoras, and Pterodoras) recovered by morphological data (herein and in Higuchi, 1992) was not corroborated in molecular-based studies (Moyer et al., 2004; Arce et al., 2013).

Higuchi's (1992) hypothesis for fimbriate-barbel doradids also slightly differs from the results herein, especially in his treatment of Nemadoras as monophyletic and sister to Trachydoras, and of Hassar as sister to Hemidoras (plus former Opsodoras). The results herein strongly support Nemadoras (sensu Higuchi, 1992; Sabaj \& Ferraris, 2003; Ferraris, 2007) as polyphyletic with neither subunits closely related to Trachydoras, and Hassar as closely related to Anduzedoras and Leptodoras. The sister-group relationship between Anduzedoras and Leptodoras was previously reported in other studies (Sabaj, 2002; Birindelli et al., 2008; Birindelli \& Sousa, 2010).

The synonymization of Hemidoras and Opsodoras based on the results obtained in the present analysis is corroborated by molecular data (Moyer et al., 2004; Arce et al., 2013). However, the monophyly of Tenellus and its close relationship with Anduzedoras, Hassar, and Leptodoras are only partially corroborated in some of the analyses based on molecular data (Moyer et al., 2004; Arce et al., 2013). Similarly, despite the good support for the monophyly of Ossancora, and the close relationship between Oxydoras and fimbriate-barbel doradids, these were not recovered by the molecular data (Moyer et al., 2004; Arce et al., 2013).

This study represents the most comprehensive morphological data set assembled for the Auchenipteridae and Doradidae, with 311 characters presented, illustrated, discussed and coded for 23 of Auchenipteridae and 57 species of Doradidae, in addition to 20 species of 16 other catfish families included as outgroups. As a result, a new classification for the Doradoidea is proposed, as well as many new characters and interrelationship hypotheses. Furthermore, a new hypothesis for the position of the Doradoidea among catfishes is presented. The incongruences between the results obtained herein and those in the previous studies are identified, discussed, and remain to be resolved by future studies.

Comparative Material Examined. All measurements refer to standard length (SL). Specimens are listed as alcohol-preserved (alc), clear and stained (cs), and dry skeleton (sk). Taxa included in the phylogenetic matrix are indicated by asterisks. Specimens are from Brazil, unless noted otherwise. Amphiliidae. Amphilius jacksoni*. UMMZ 199987 (4 cs, 30.9-100.0 mm), Zambia, Mpika, Lwitikila River. Ariidae. Arius herzbergii. MZUSP 52847 (1 alc, 192.0 mm), Alagoas, Coqueiro Seco, Lagoa Mandaú (9³7's 3548’W). Galeichthys peruvianus*. MZUSP 94844 ( 1 alc, 105 mm, 1 sk, 208.0 mm), Perú, Lima, Callao, 12¹2’35"S 775'15"W. Genidens genidens*. MZUSP 51721 (1 cs, 128 mm), Bahia, Nova Viçosa, rio Peruíba, (1754’S 39²2’W). MZUSP 51693 (1 sk, 250.0 mm), São Paulo, Juréia, Ilha do Bom Abrigo. MZUSP 49319 (1 alc, 115 mm), São Paulo, Cananéia. Aspredinidae. Bunocephalus coracoideus*. MZUSP 28835 (1 cs, 68.6 mm), no data. MZUSP 30713 (1 alc, 71.0 mm), Amazonas, Tefé, rio Tefé (3²2’S 6443’W). MZUSP 103254 (1 sk, 67.0 mm), Amapá, Lanranjal do Jari, Igarapé Arapiranga, tributary of rio Jari (047’41"S 52²7’10"W). Pseudobunocephalus bifidus. MZUSP 50107 (2 cs, 33.3-54.0 mm), Acre, Manoel Urbano, rio Purus (848'S 69¹5’W). Auchenipteridae. Ageneiosus atronasus*. MZUSP 52620 (20 alc, 80.1-89.0 mm, 2 cs, 79.8-87.0 mm), Amazonas, rio Purus at Beruri ( $\left.3^{\circ} 55^{\prime} \mathrm{S} 61^{\circ} 22^{\prime} \mathrm{W}\right)$. MZUSP 63629 (1 cs, 88.0

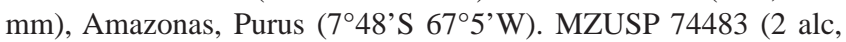
84.5-87.3 mm), Amazonas, Lago Janauacá, rio Solimões ( $3^{\circ} 22^{\prime} \mathrm{S}$ 60¹1’W). Ageneiosus brevis. MZUSP 34417 (567 alc, 52.8-60.4 mm, 3 cs, 53.0-61.6 mm), Rondônia, rio Madeira at Calama (8³'s 6253’W). MZUSP 56660 (1 alc, 95.6 mm), Amazonas, rio Purus (4³’48"S 61³3'49"W). Ageneiosus inermis*. MZUSP 89519 (1 sk, $250 \mathrm{~mm}$ ), Goiás, Luís Alves, rio Verde, tributary of rio Araguaia (13928"S 50³0’22"W). MZUSP 91661 (2 sk, 260.0-320.0 mm), Goiás, Luís Alves, rio Verde, tributary of rio Araguaia (139'28"S 50³0’22"W). MZUSP 92005 (1 sk, 420 mm), Mato Grosso,

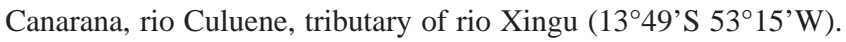
MZUSP 96189 (3 sk, 255-315 mm), Amazonas, Manaus, Porto Ceasa. Ageneiosus militaris. MZUSP 21114 (1 alc, 179 mm), Paraná, Guaíra, rio Paraná, above Cachoeira Sete Quedas (244' 5 5416’ W). Ageneiosus ucayalensis. MZUSP 98333 (1 alc, 165 mm), Pará, Jacareacanga, rio Teles Pires, tributary of rio Tapajós (9¹9’1"S 
5646’44"W). Ageneiosus vittatus. MZUSP 92185 (1 alc, 168 mm), Amazonas, Igarapé Castanha, tributary of rio Tiquié, rio Negro basin (24’41"N 6941’26"W). MZUSP 101771 (1 sk, 158 mm), Pará, Monte Dourado, rio Jari (0³9’45"S 52³1’40"W). Ageneiosus sp. MZUSP 92639 (1 alc, 106 mm), Pará, Itaituba, rio Tapajós (4²1’34"S 56¹0’3"W). Asterophysus batrachus*. INPA 24119 (1 cs, 127.0 $\mathrm{mm})$, Amazonas, Novo Airão, rio Negro, Arquipélogo de Anavilhanas (2³7’S 6050’W). MZUSP 12420 (1 alc, 129.7 mm), Amazonas, Paricatuba, rio Negro ( $\left.0^{\circ} 31^{\prime} \mathrm{S} 65^{\circ} 1^{\prime} \mathrm{W}\right)$. MZUSP 33410 (1 alc, 149.8 mm), Amazonas, São Gabriel da Cachoeira, rio Negro (07’S 675’W). Auchenipterichthys longimanus. MZUSP 52103 (1 sk, 167 mm), Amazonas, flood between rio Mamirauá and rio Negro $\left(0^{\circ} 24^{\prime} \mathrm{S}\right.$ 65¹2'W). MZUSP 57109 (1 alc, 123.3 mm), Pará, Capim, rio Capim (2²'S 4745’W). Auchenipterichthys punctatus. MZUSP 43333 (1 alc, $119.7 \mathrm{~mm}$ ), Amazonas, rio Jutaí (3¹1’s 675’W). Auchenipterichthys coracoideus. MZUSP 86218 (1 alc, 91.2 mm), Mato Grosso, Cocalinho, Corixo da Saudade, tributary of rio Araguaia (14¹7’20"S 519'12"W). MZUSP 15304 (1 cs, 40.6 mm), Peru, Loreto, Iquitos, río Nanay ( $\left.3^{\circ} 41^{\prime} S 73^{\circ} 13^{\prime} \mathrm{W}\right)$. Auchenipterichthys thoracatus*. MZUSP 63034 (1 alc, 101.9 mm), Mato Grosso, Vila Bela da Santíssima Trindade, rio Guaporé, tributary of rio Madeira (15¹’17"S 5957’W). MZUSP 37518 (1 cs, 78.7 mm), Mato Grosso, Vila Bela da Santíssima Trindade, rio Guaporé, tributary of rio Madeira (15¹'17"S 5957’W). Auchenipterus ambyacus. MZUSP 30611

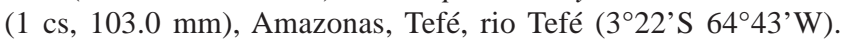
Auchenipterus nuchalis. MZUSP 89728 (1 alc, 130.5 mm, 1 sk, 135.2 $\mathrm{mm})$, Mato Groso, Canarana, rio Culuene, tributary of rio Xingu (1349’S 53¹5’W). MZUSP 97375 (2 sk, 117.0-120.0 mm), Pará, Novo Progresso, rio Jamanxim (743’51"S 55¹6’36"W). Auchenipterus osteomystax*. MZUSP 33414 (1 cs, 141.0 mm), Pará, Itaituba, rio Tapajós (427’'S 56¹5’W). Auchenipterus brachyurus. MZUSP 49830 (1 alc, $121 \mathrm{~mm}$ ), Acre, rio Acre. Centromochlus heckelii*. MZUSP 49529 (2 alc, 80.5-97.4 mm, 2 cs, 68.1-83.4 mm), Amazonas, rio Purus (844’S 67²4’W). MZUSP 101767 (4 sk, 82.7-84.0 mm), Pará, Monte Douraado, rio Jari (0³9’45"S 52³1'40"W). Entomocorus radiosus*. MZUSP 59465 (1 alc, 36.8 $\mathrm{mm}, 2 \mathrm{cs}, 37.2-41.2 \mathrm{~mm}$ ), Mato Grosso do Sul, rio Miranda, tributary of rio Paraguay (19³7’22"S 5657’27"W). MZUSP 59327 (1 cs, 35 $\mathrm{mm}$ ), aquarium store. Epapterus dispilurus*. MZUSP 26410 (1 cs, 62.0 mm), Perú, Amazonas, río Ucayali, Pucallpa (8²3’S 74³3’W). Gelanoglanis cf. stroudi*. MZUSP 96032 (5, 11.8-26.4 mm, 1 cs, $19.4 \mathrm{~mm})$, rio Teles Pires (1058’30"S 5544'3"W). Glanidium melanopterum*. MZUSP 51043 (1 cs, 107.9 mm), São Paulo, rio

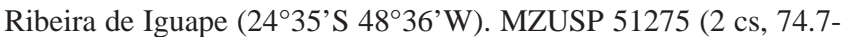
$79.9 \mathrm{~mm}$ ), São Paulo, Registro, rio Ribeira de Iguape (24³5’S 4751'W). MZUSP 64256 (1 alc, 105.0 mm, 1 cs, 108.4 mm, 2 sk, 110.0-112.0 mm), São Paulo, Iporanga, rio Ribeira de Iguape (24³5’S 48³5’W). Liosomadoras oncinus*. MZUSP 46015 (1 alc, $55.4 \mathrm{~mm}$ ), aquarium store. MZUSP 93497 (2 alc, 65.8-74.8 mm, 1 cs, 70.7 mm), aquarium store. MZUSP 105828 (3 sk, 110-120 mm), Venezuela, Amazonas, río Ventuari (44’39"N 6652’6"W). MNRJ 17640 (1 cs, 125 mm), no data. Pseudauchenipterus affinis*. MZUSP 51718 (2 alc, 75.3-86.5 mm, 1 cs, 63 mm), Espírito Santo, Linhares, rio Doce (19²4’S 40¹’W). MZUSP 51720 (1 cs, 68.6 mm), Espírito Santo, São Mateus, rio São Mateus (1844'S 3950’W). MZUSP 60075 (1 cs, 88.7 mm), Bahia, Mucurí, rio Mucurí (186’S 39³2’W). Pseudauchenipterus nodosus. ANSP 179581 (1 sk, unmeasured), Guiana, Georgetown, fish market. Pseudepapterus hasemani. MZUSP 53323 (12 alc, 54.0-70.6 mm, 2 cs, 64.2-64.8 mm), Pará, Porto de Moz, rio Acaraí, tributary of rio Xingu (2³’47"S 52¹8’45"W). MZUSP 104772 ( 1 alc, 115.2 mm), Pará, Monte Dourado, rio Jari (047’55"S 52³1'50"W). Pseudotatia parva*. FMNH 57807 (2 alc, c.35 mm, 2 cs, c.34 mm), Bahia, Juazeiro, rio São Francisco (9²6'S 40³0’W). Tatia aulopygia*. MZUSP 37599 (2 alc, 60.871.1 mm, 2 cs, 48.6-58.6 mm), Mato Grosso, Aripuanã, Igarapé do Aeroporto, rio Madeira basin (9॰58'S 59¹9'W). Tatia cf. aulopygia: MZUSP 99309 (2 sk, 89.0-94.0 mm), no data. Tatia intermedia. MZUSP 89376 (2 cs, 35.2-66.0 mm), Goiás, Crixás, Córrego da Taboca, rio Araguaia basin (14¹9’27"S 50¹2’32"W). Tetranematichthys quadrifilis*. MZUSP 37517 (1 cs, 114 mm), Mato Grosso, Vila Bela da Santíssima Trindade, rio Guaporé, tributary of rio Madeira (15¹'17"S 5957’90"W). Tetranematichthys wallacei. MZUSP 85497 (1 alc, 193 mm), Amazonas, Santa Isabel do rio Negro, rio Negro ( $\left.0^{\circ} 24^{\prime} \mathrm{S} 65^{\circ} 2^{\prime} \mathrm{W}\right)$. Tocantinsia piresi*. MZUSP 98301 (1 sk, 250.0 mm), Pará, Jacareacanga, rio Teles Pires (9¹8’56"S 56²7’10"W). MZUSP 100031 (2 sk, 430.0-440.0mm), Pará, Jacareacanga, rio Teles Pires (9¹8’42'S 5646’47"W). Trachelyichthys decaradiatus*. MZUSP 92829 (1 alc, 66.3 mm, 4 cs, 35.0-54.0 mm), Pará, Santarém, Igarapé Juá, rio Tapajós basin (2²6’0"S 5446’51"W). MZUSP 6830 (2 cs, 53.1-55.8 mm), Amazonas, Manaus, Igarapé tributary of rio Tarumãzinho, rio Negro basin ( $\left.3^{\circ} 10^{\prime} \mathrm{S} 60^{\circ} 0^{\prime} \mathrm{W}\right)$. Trachelyopterichthys taeniatus*. MZUSP 8496 ( 1 alc, 107.0 mm, 2 cs, 53.8-82.4 mm), Pará, Santarém, Igarapé afluente do rio Mapiri (2²6'S 544ㄴ'W). Trachelyopterus ceratophysus: MZUSP 52087 (1 cs, 165 mm), Amazonas, rio Negro (0²4’S 6512’W). Trachelyopterus coriaceus*. MZUSP 92767 (3 cs, 73.0-94.2 mm), Pará, Santarém, Lago Maiacá (2²7’54"S 54³9’31"W). Trachelyopterus galeatus*. MZUSP 90831 (2 alc, 127.2-138.8 mm), Minas Gerais, Várzea da Palma, rio São Francisco (17³6’56"S 4440’33"W). MZUSP 9304 (2 cs, 98.3-99.4mm),

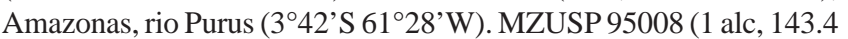
$\mathrm{mm})$, Mato Grosso, Barão de Melgaço, rio Miranda, tributary of rio Paraguay (16¹9’30"S 5549’59"W). Trachelyopterus peloichthys. MZUSP 79458 (5 alc, 109.3-135.2 mm), Venezuela, Zulia, Carrasquero, río Limón, Lago Maracaibo basin. Trachelyopterus porosus. MZUSP 75365 (1 cs, $81.3 \mathrm{~mm})$, Amazonas, Manaus, Lago Janauari, rio Negro (3¹2’S 60¹’W). MZUSP 75364 (2 cs, 65.5$77.3 \mathrm{~mm}$ ), Amazonas, Manaus, Ilha da Marchantaria, rio Solimões. MZUSP 31889 (1 cs, 106.6 mm), Pará, Alter do Chão, rio Tapajós ( $\left.{ }^{\circ} 30^{\prime} \mathrm{S} 54^{\circ} 57^{\prime} \mathrm{W}\right)$. Trachelyopterus striatulus. MZUSP uncatalogued (3 sk, 81.1-93.7 mm), no data. MZUSP 90742 (2 alc, 151-154 mm), Espírito Santo, Anchieta, rio Salinas (2044’15"S 4041’59"W). Trachelyopterus teaguei. MCP 18423 (2 cs, 115.8-123.8 mm), Santa Catarina, Concórdia, rio do Peixes at Volta Grande, rio Uruguai basin

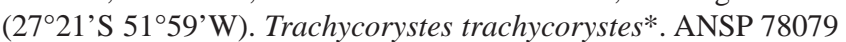
(1 sk, unmeasured), Guiana, Essequibo. ANSP 179152 (1 sk, unmeasured), Guiana, Rupununi, Simoni River (343'9"N 59¹5’40"W). MZUSP 7381 (1 cs, 128.8 mm), Amazonas, Maués, Igarapé Limãozinho (324’S 57²2’W). MZUSP 52088 (1 sk, 165 $\mathrm{mm}$ ), Amazonas, rio Negro, Anavilhanas (242’S 6045’W). MZUSP 52095 (1 alc, 310 mm), Amazonas, São Pedro, upper rio Negro. MZUSP 91659 (1 sk, 200.0 mm), no data. MZUSP 99308 (1 sk, $180.0 \mathrm{~mm}$ ), no data. no data. Callichthyidae. Corydoras aeneus. MZUEL 8130 (1 alc, 36.0 mm), Mato Grosso, Tangará da Serra, ribeirão do Sapo (4³3’25'’S 5748'45'”W). Clariidae. Clarias sp. MZUSP 91656 (1 sk, 430.0 mm), Espírito Santo, Anchieta, rio Grande (2042'23"S 40³9'0"W). Claroteidae. Chrysichthys auratus*. MZUSP 27171 (1 cs, 101.0 mm), Egito, Nilo, Nasarah. Diplomystidae. Diplomystes campoensis*. MZUSP 88533 (1 sk, 172.5 mm), Chile, Los Lagos/ VIII Región, río San Pedro, Lago Riñihue basin. Diplomystes mesembrinus. MZUSP 62595 (1 alc, 99.2 mm), Argentina, Chubut, Los altares, río Chubut (4349’S 6754’W). Doradidae. Acanthodoras cataphractus*. MZUSP 6831 (1, 119.0 $\mathrm{mm}, 1 \mathrm{cs}, 112.0 \mathrm{~mm})$, Amazonas, Manaus, tributary of rio 
Tarumãzinho (3¹0’S 600’W). MZUSP 82295 (2 alc, 156.2-185.5 $\mathrm{mm}$ ), rio Branco, Cachoeira Bem-Querer. MZUSP 84667 (2 cs, 57.0$58.0 \mathrm{~mm}$ ), aquarium store. Acanthodoras spinosissimus. ANSP 179341 (1 sk, unmeasured), Guiana, Rupununi, Simoni River (343’9"N 59¹5’40"W). Agamyxis albomaculatus*. ANSP 180889 (1 alc, $68.4 \mathrm{~mm}$ ), Venezuela, río Orinoco at Isla Portuguesa. MZUSP 88607 (3, 64.3-97.7 mm, 1 cs, 72.2 mm), Venezuela, Delta Amacuro, río Orinoco ( $\left.8^{\circ} 37^{\prime} 20^{\prime \prime} \mathrm{N} 61^{\circ} 47^{\prime} 30^{\prime \prime} \mathrm{W}\right)$. Agamyxis pectinifrons: INHS 43281 ( 1 alc, 91.7 mm), Perú, río Itaya. MZUSP 5177 (1 alc, 82.3 $\mathrm{mm})$, Mato Grosso, rio Papagaio, rio Tapajós basin (132' $\left.58^{\circ} 17^{\prime} \mathrm{W}\right)$. MZUSP 27806 (1 alc, 83.3 mm), Bolívia, Trinidad, Laguna San José. MZUSP 57766 (1 alc, 49.4 mm), Amazonas, rio Purus (358’47"S 6129'6"W). Anadoras grypus*. ANSP 166262 (1 alc, 114.3 mm), Perú, río Marañon. ANSP 179558 (1 sk, unmeasured), Peru, Loreto, Maynas, Caño Moena (346’19"S 73¹4'16"W). MZUSP 5934 (1

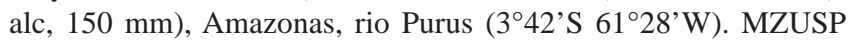
5971 (1 cs, unmeasured), Amazonas, rio Purus ( $3^{\circ} 42^{\prime} \mathrm{S} 61^{\circ} 28^{\prime} \mathrm{W}$ ). MZUSP 6896 ( 1 alc, 112.9 mm, 1 cs, 94.0 mm), Amazonas, Iranduba, Lago Janauari (3¹3’S 604’W). MZUSP 50136 (1 alc, 115.7 mm), Amazonas, Itacoatiara, Ilha Amatari (3¹8'S 5857’W). MZUSP 50148 (1 alc, 92.5 mm), Amazonas, Lago Janauacá (3²5’S 60¹7’W). MZUSP 74864 (1 alc, 140.0 mm, 1 sk, 123.2 mm), Amazonas, Lago Janauacá ( $\left.3^{\circ} 22^{\prime} \mathrm{S} 60^{\circ} 11^{\prime} \mathrm{W}\right)$. Anduzedoras oxyrhynchus*. ANSP 160628 (1 alc, $108.2 \mathrm{~mm}$ ), Venezuela, Amazonas, río Sipapo (452’N 675' W). ANSP 178551 (1 sk, unmeasured), Amazonas, rio Negro (1¹2’34"S 62¹3’47"W). MZUSP 29021 (2 alc, 92.1-115.7 mm), Amazonas, rio Negro (031'S 6450’W). MZUSP 29028 (2 alc, 34.5$56.8 \mathrm{~mm}$ ), Amazonas, rio Negro (0²4'S 6512'W). MZUSP 29029 (215, 31.0-92.3 mm, 2 cs, 56.0-92.3 mm), Amazonas, rio Negro (058’'S 6257’W). MZUSP 91454 ( 1 alc, 228.0 mm), Amazonas, Vista Alegre, rio Negro ( $\left.0^{\circ} 21^{\prime} \mathrm{S} 68^{\circ} 27^{\prime} \mathrm{W}\right)$. Astrodoras asterifrons*. MZUSP 8534 (3 cs, 60.0-70.0 mm), Pará, Santarém, rio Tapajós (5444’0"W 2²5’0"S). MZUSP 50833 (1 cs, 60.0 mm), Roraima, Rorainópolis, rio Jauaperi (61²6’0"W 0³9’0"S). Centrochir crocodili*. MZUSP 105837 (1 sk, 150.8 mm), Colombia, Tolima, río Magdalena (5¹2'16"N 7444’03"W). CU 47930 (1 cs, 130.0 mm), Colombia, río Magdalena. Centrodoras brachiatus*. ANSP 179155 (1 sk, unmeasured), Amazonas, rio Solimões (244’15"S 6656’7"W). ANSP 179164 (1 sk, unmeasured), Amazonas, Santo Antônio do Içá, rio Solimões (36오 6756’W). ANSP 181021 (1 alc, 81.5 mm), Pará, Vila Canaã, rio Amazonas. MZUSP 31306 (1 alc, 186.0 mm), no data. MZUSP 42335 (1 cs, 264.0 mm), Amazonas, Tefé, rio Solimões. MZUSP 51039 (1 alc, 230.0 mm), Pará, Juriti, (29’S 566’W). MZUSP 55776 ( 1 cs, 76.2 mm), Amazonas, rio Solimões ( $3^{\circ} 15^{\prime} 4^{\prime \prime S}$ 6445’19"W). MZUSP 83313 (1 sk, $158.0 \mathrm{~mm}$ ), Amazonas, rio Madeira, (3³8'14"S 59²'17"W). Centrodoras hasemani*. ANSP 17955 (1 sk, unmeasured), Amazonas, rio Negro (3¹’18"S 60²4'55"W). ANSP 177907 ( 1 alc, 209 mm), Amazonas, at confluence between rio Negro and rio Branco. ANSP 181031 (1 alc, 69 mm), Amazonas, rio Negro. INPA 11338 (1 alc, 147.2 mm), Amazonas, Novo Airão, rio Negro (2³7’S 6056’W). MZUSP 56037 (1 cs, 71.9 $\mathrm{mm}$ ), Amazonas, rio Negro (37’17"S 608’20"W). MZUSP 91675 (1 alc, 202.0 mm), Amazonas, rio Uaupés, rio Negro basin. Doraops zuloagai*. ANSP 179558 (2 sk, unmeasured), Venezuela, Zulia, río Catatumbo, Lago Maracaibo basin. INHS 54804 (1 alc, 273 mm), Venezuela, Lago Maracaibo basin. MCNG 33457 (1 alc, 103.8 mm), Venezuela, Zulia, río Escalante, Lago Maracaibo basin. Doras carinatus*. ANSP 177276 (1 alc, $124.5 \mathrm{~mm}$ ), Guiana, Essequibo River (442’3"N 5842’44"W). ANSP 187399 (1 sk, 170.0 mm), Guiana, Lawa River, Maroni River basin (3¹9’31"N 54³’48"W). ANSP 180986 (1 sk, 170.0 mm), Guiana, Essequibo River (154'53"N 58³1’14’). AMNH 96798 (1 alc, 302 mm), Venezuela, Bolivar, río
Crapo (5³0’40"N 63³0’40"W). Doras higuchii*. ANSP 181056 (1 cs, $60.0 \mathrm{~mm}$ ), Mato Grosso, rio Curisevo (13²'5"S 5325'10"W). ANSP 181057 (1 alc, 160.0 mm), Pará, Belo Monte, rio Xingu ( $3^{\circ} 7^{\prime} \mathrm{S}$ 514ㄱ'W). INPA 5568 (1 alc, $83.8 \mathrm{~mm}$ ), Amazonas, rio Trombetas. MZUSP 96334 (1 sk, 165.0 mm), Pará, Altamira, rio Curuá (8¹9’7"S 555’23"W). MZUSP 101693 (2 sk, 105.0-172.0 mm), Pará, Monte Dourado, rio Jari (0³3’59"S 52³4’40"W). MZUSP 110620 (1 sk, 230.0 mm), Pará, Altamira, rio Xingu (3¹2’2"S 52¹1’46"W). Doras micropoeus. ANSP 78070 (1 sk, 160 mm), no data (Hyrtl Collection). ANSP 178703 (1 alc, 222 mm), Guiana, Essequibo River (444’ N 5843’W). ANSP 187110 (1 alc, 174 mm, 2 sk, 205-210 mm), Suriname, Lawa River, Maroni River basin (5³1'N 57²12’W). Doras phlyzakion*. ANSP 181055 (1 alc, 148.0 mm), Amazonas, rio Tefé (3³8'S 6459’W). MZUSP 82294 (2 alc, 175.0-180.0 mm, 1 sk, 162.0 mm), Amazonas, rio Tefé. MZUSP 50836 (1cs, 67.5 mm), Amazonas, Lagoa Central, rio Negro basin. Doras zuanoni. MZUSP 96328 (1 alc, 96.0 mm), Tocantins, Caseara Lago Paredão, rio Araguaia basin (9¹7'S 4958'W). Franciscodoras marmoratus*. MZUSP 2201 (1 cs, 99.0 mm), Bahia, rio São Francisco. MZUSP 9380 (1 cs, $183.0 \mathrm{~mm})$, Minas Gerais, Buritis, rio Urucuia, rio São Fransico basin (153’'S 46²5’W). MZUSP 84224 (1 cs, 103.8 mm), Minas Gerais, Três Marias, rio São Francisco. MZUSP 97145 (3 cs, 29.4-33.0 $\mathrm{mm})$, Minas Gerais, Três Maria, rio São Fracisco. Hassar affinis*. MZUSP 74890 (1 cs, 85.9 mm), Parnaíba. MZUSP 43604 (1 alc, 152.0 mm), Piauí, Teresina, rio Parnaíba. MZUSP 89935 (1 cs, 108.7 mm), Piauí, Parnaguá, Lagoa de Parnaguá (10¹4’41"S 44³8’50"W). MZUSP 90583 (1 alc, 54.4 mm), Piauí, Guadalupe, rio Parnaíba (645’44"S 43³3’53"W). Hassar gabiru*. MZUSP 110599 (2 sk, 98.0-165.0 mm SL), Pará, Altamira, rio Xingu (3¹2’2"S 52¹1’46"W). Hassar orestis*. ANSP 180294 (1 sk, unmeasured), Venezuela, Amazonas, río Ventuari $\left(4^{\circ} 45^{\prime} \mathrm{N}\right.$ 66²2 $\left.1^{\prime} \mathrm{W}\right)$. MZUSP 6991 (1 cs, $71.0 \mathrm{~mm}$ ), Amazonas, Nova Olinda do Norte, rio Madeira (353’S 595’W). MZUSP 15512 (1 alc, 132.0 mm), Pará, Trombetas, rio Trombetas (1²0'S 5651'W). MZUSP 32542 (2 sk, 205.0-220.0 mm), Pará, Belo Monte, rio Xingu (37’S 5142’W). MZUSP 46010 (1 cs, 76.9 mm), Amazonas, Coari, rio Solimões (355'S 63²0’ W). MZUSP 105827 (1 sk, 138.5 mm), Venezuela, Amazonas, río Ventuari (4¹3’7"N 66²5’26"W). Hemidoras boulengeri. MZUSP 62641 (1 alc, $147.3 \mathrm{~mm}$ ), Amazonas, Manaquiri, Lago Janauacá, rio Solimões (325'S 60¹7’W). Hemidoras morei*. MZUSP 26316 (1 alc, 102.3115.2 mm), Perú, Pucallpa. MZUSP 27844 (1 cs, 90.6 mm), Bolívia, Bení, Trinidad, río Ibare, rio Madeira basin. MZUSP 31104 (1 alc, $167.7 \mathrm{~mm})$, Amazonas, Santa Isabel do rio Negro, rio Marauiá, rio Negro basin ( $0^{\circ} 24^{\prime} \mathrm{S} 65^{\circ} 12^{\prime} \mathrm{W}$ ). MZUSP 32526 (3 alc, 135.0-138.0 mm, 2 sk, 137.7-153.2 mm), Amazonas, rio Negro (07’S 675’ W). MZUSP 82288 (1 alc, $154.1 \mathrm{~mm}$ ), no data. Hemidoras morrisi*. ANSP 180191 (1 sk, unmeasured), Perú, Loreto, Maynas, rio Nanay (346’45"S 73²2’6"W). MZUSP 28378 (2 alc, 157.0-164.0 mm), Rondônia, Lago Piauí, foz do rio Jamari, rio Madeira basin (8²7’S 63³0’W). MZUSP 56044 (2 alc, 58.2 mm), Amazonas, rio Jutaí (252’36"S 6659’20"W). MZUSP 56683 (1 cs, $93.2 \mathrm{~mm}$ ), Amazonas, Benjamin Constant, rio Solimões (4²4'S 6949’ W). Hemidoras stenopeltis*. ANSP 179240 (1 sk, unmeasured), Amazonas, rio Solimões (2³5’29"S 65²9’52"W). MZUSP 7541 (1 alc, $114.1 \mathrm{~mm}$ ), Amazonas. MZUSP 7612 (2 alc, 55.3-96.0 mm, 1 cs, 74.8 mm), Amazonas, Urucará (2³7’S 57²4'). MZUSP 29052 (2 cs, 67.9-69.4 mm), Rondônia, rio Madeira at Calama (8³’S 6253’W). MZUSP 42772 (1 alc, 108.7 mm), Amazonas, rio Aripuanã. Hemidoras stubelii*. MZUSP 26316 (2 alc, 102.3-114.9 mm), Perú, Pucallpa, río Ucayali. MZUSP 56879 (1 cs, 64.5 mm), Amazonas, rio Purus (351'9"S 61²3’25"W). MZUSP 57620 (1 alc, 59.6 mm), Amazonas, rio Negro (34'4"S 60¹4'58"W). Kalyptodoras 
bahiensis*. MZUSP 87841 (1 sk, 233.0 mm), Bahia, Itaberaba, rio Paraguassú. MZUSP 87842 (8 alc, 129.0-196.0 mm, 1 sk, 152.0 $\mathrm{mm})$, Bahia, Iaçu, rio Paraguassú. Leptodoras acipenserinus. ANSP 178467 (1 alc, 106.7 mm), Peru, río Nanay. Leptodoras copei. ANSP 162461 (1 alc, $96.5 \mathrm{~mm}$ ), Venezuela, Amazonas, río Orinoco. Leptodoras hasemani. ANSP 175888 (1 cs, 81.8 mm), Guiana, Essequibo River. ANSP 179209 (1 sk, unmeasured), Guiana, Rupununi, Rupununi river, Essequibo drainage. MZUSP 37009 (1 alc, $132.8 \mathrm{~mm}$ ), Roraima, Boa Vista, rio Branco (250’ $\mathrm{N} 60^{\circ} 40^{\prime} \mathrm{W}$ ). MZUSP 110600 (1 sk, 118.0 mm SL), Pará, Altamira, rio Xingu (3³6’31"S 52²1'3"W). Leptodoras juruensis*. ANSP 179168 (1 sk, unmeasured), rio Amazonas. INHS 39465 (1 alc, 117.4 mm), Peru, río Amazonas. MZUSP 57054 (1 cs, 105.0 mm), Amazonas, rio Solimões (3¹1'1'S 6448'42"W). MZUSP 104532 (1 sk, 227.0 mm), Rondônia, Porto Velho, rio Madeira (8³2'12"S 63³4’5"W). Leptodoras marki*. MZUSP 103217 (1 alc, 80.3 mm, 1 cs, 83.2 mm), Pará, São Felix do Xingu, Igarapé Manguari (6³5’42"S 5148’48"W). Leptodoras myersi. MZUSP 55839 (1 cs, $83.8 \mathrm{~mm}$ ), Amazonas, rio Solimões (3¹1'17"S 6448’47"W). Leptodoras oyakawai*. ANSP 187336 (1 sk, 120 mm), Pará, Novo Progresso, rio Jamanxim, tributary of rio Tapajós (7³'51"S 55²6’28"W). MZUSP 87028 (1 alc, 54 mm), Mato Grosso, Gaúcha do Norte, rio Curisevo, tributary of rio Xingu (13²'5"S 53²3'19"W). MZUSP 97722 (1 cs, $73.0 \mathrm{~mm}$ ), Mato Grosso, Paranaíta, rio Teles Pires (9²7’7"S 56³0’46"W). Leptodoras praelongus*. ANSP 162463 (1 alc, 142 mm), Venezuela, río Pamoni. ANSP 179156 (1 sk, unmeasured), Roraima, rio Branco, tributary of rio Negro (1²0’34"S 6152'21"W). MZUSP 31694 (1 alc, unmeasured), Pará, Belo Monte, rio Xingu (37’S 5142’W). MZUSP 56674 (1 cs, 82.7 mm), Roraima, rio Branco (1¹8’49"S 6152’3"W). Lithodoras dorsalis*. MZUSP 9379 (1 cs, 134.0 mm), Pará, Icoaraci (1¹8’S 48²9’W). MZUSP 62584 (1 alc, 163.0 mm), Pará, Vigia (052’S 488’W). MZUSP 62585 (2 alc, 115.0-118.0 mm), Pará, Icoaraci (1¹8’S 48²9’W). MZUSP 58326 ( 1 alc, $170.0 \mathrm{~mm}$ ), Amazonas, rio Amazonas (1²7’10"S 4857’10"W). MZUSP 13955 (1 alc, 740.0 mm), Rondônia, rio Machado, rio Madeira basin. MZUSP 91562 (1 sk, 478.0 mm), Pará, Belém, fish market at Icoaraci. Megalodoras guayoensis*. ANSP 177980 (143.9 mm), Venezuela, río Orinoco. ANSP 179167 (1 sk, unmeasured), Venezuela, Delta Amacuro, río Orinoco (8²8’24"N 6117’12"W). Megalodoras uranoscopus*. MZUSP 8284 (1 alc, 337.0 mm), Pará, Oriximiná, Lago Paru, rio Trombetas basin (152’S 5550’W). MZUSP 5647 (1 alc, 570.0 mm), Pará, Oriximiná, Lago Paru, rio Trombetas basin (1 ${ }^{\circ} 52^{\prime}$ S 555'' W). MZUSP 14026 (1 alc, $410.0 \mathrm{~mm}$ ), Rondônia, rio Machado, rio Madeira basin. MZUSP 25308 (1 alc, 315.0 mm), Pará, Itapacura, rio Tapajós (4³7’S 56²'W). MZUSP 46007 (1 alc, 16.02 mm), Tocantins. MZUSP 55838 (1 cs, 73.0 mm), Amazonas, Jutaí, rio Solimões (2³1’37’S 66³6’27"W). MZUSP 110601 (1 sk, 104.0 mm SL), Pará, Porto de Moz, rio Xingu (2॰11’56"S 52॰8'9"W). Nemadoras elongatus*. ANSP 179239 (2 sk, unmeasured), Amazonas, rio Solimões, 254’34"S 6750’1"W). MZUSP 56013 (1 alc, 99.2 mm, 1 cs, 92.0 mm, 1 sk, $101.6 \mathrm{~mm})$, Amazonas, Barcelos, rio Negro (1²3’1"S 6155’50"W). MZUSP 56021 ( 1 alc, 46.1 mm), Amazonas, rio Negro (38’24"S 607’20"W). Nemadoras hemipeltis*. MZUSP 56688 (1 cs, 81.8 $\mathrm{mm})$, Amazonas, Benjamin Constant, rio Içá (4²4’S 6949’W). Nemadoras humeralis*. ANSP 179157 (2 sk, unmeasured), Amazonas, rio Amazonas (3²1’22"S 58³8'52"W). MZUSP 6990 ( 1 alc, $75.6 \mathrm{~mm}$ ), Amazonas, rio Madeira (3॰53'S 595'W). MZUSP 19306 (1 sk, $120 \mathrm{~mm}$ ), Amazonas, Manaus, rio Negro (3¹0’S 600’W). MZUSP 55996 ( 1 cs, 58.0 mm, 1 alc, $60.1 \mathrm{~mm}$ ), Amazonas, rio Juruá (2॰37’5"S 6547’43"W). MZUSP 56014 (1 alc, $103.8 \mathrm{~mm}$ ), Amazonas, rio Içá (38’56"S 68¹’59"W). MZUSP 56606 (1cs,
86.4 mm), Amazonas, rio Amazonas (3¹9’59"S 58³5’59"W). MZUSP 104533 (1 sk, $124.1 \mathrm{~mm}$ ), Rondônia, Porto Velho, rio Madeira (8`51'43"S 64³'37’W). Nemadoras sp. (juvenile). MZUSP 74280 (2 cs, 14.8-15.7 mm), Amazonas, Anavilhanas, rio Negro (242'S 6045’W). Orinocodoras eigenmanni*. ANSP 177996 (1 sk, unmeasured), Venezuela, Delta Amacuru, río Orinoco (8³7’20"N 614’30"W). AUM 5318 (1 alc, 119.6 mm), Venezuela, Portuguesa, Caño Maraca, río Orinoco basin (849’N 69²0’W). INHS 40330 (1 cs, $57.8 \mathrm{~mm}$ ), Venezuela, Caño Guaritico, río Orinoco basin ( $7^{\circ} 33^{\prime} \mathrm{N}$ 69³9’W). FMNH 105276 (1 sk, 193.0 mm), Venezuela, Caño Anabata, tributary of río Orinoco ( $\left.8^{\circ} 37^{\prime} 20^{\prime \prime} \mathrm{N} 61^{\circ} 47^{\prime} 33^{\prime \prime W}\right)$. Ossancora asterophysa*. MZUSP 5646 (1 alc, 95.4 mm), Pará, Oriximiná, Lago Paru. MZUSP 7543 (2 alc, 50.2-73.5 mm, 1 cs, 77.3 mm), Amazonas, Urucará, rio Amazonas. MZUSP 7838 (1 sk, 65.3 mm), Pará, Faro Nhamundá, Paraná do Jacaré. MZUSP 56699 (1 alc, 85.7 mm), Pará, rio Trombetas (147’30"S 5551’27"W). MZUSP 84665 (1 alc, 85.7 mm), Mato Grosso, Vila Bela da Santíssima Trindade, rio Guaporé, tributary of rio Madeira (15²1'17"S 5957’ W). Ossancora eigenmanni*. MZUSP 38176 (2 alc, 85.5-86.2 mm), Mato Grosso, Corumbá, rio Miranda, tributary of rio Paraguay (1941’S 56’58’W). MZUSP 44423 (1 alc, 62.0 mm), Mato Grosso, Cáceres, rio Paraguay (16²'S 57²1’W). MZUSP 95024 (2 alc, 38.3-65.3 mm, 3 cs, 35.1-65.6 mm), Mato Grosso, Barão de Melgaço, rio Mutum, rio Paraguay basin (16²19'30"S 5549'59"W). Ossancora fimbriata*. MZUSP 55833 (4 alc, 45.0-62.2 mm, 1 cs, 46.9 mm), Amazonas, rio Jutaí (254’25"S 670'12"W). MZUSP 56703 (1 cs, 59.0 mm), Amazonas, rio Jutaí (257’6"S 670’29"W). Ossancora punctata*. MZUSP 7839 (1 alc, 72.6 mm, 1 cs, 61.6 mm), Pará, Faro Nhamundá, Paraná do Jacaré. MZUSP 7540 (1cs, 61.7 mm), Amazonas, Urucará, rio Uatumã. MZUSP 26265 (1 alc, 34.2 mm), Perú, Pucallpa, río Ucayali. MZUSP 41096 (1 alc, 59.3 mm), Mato Grosso do Sul, Corumbá, rio Miranda (20¹4'S 56²2’W). MZUSP 95000 (1 alc, 65.8 mm), Mato Grosso, Vila Bela da Santíssima Trindade, rio Guaporé, tributary of rio Madeira (15¹'37"S 5949’9"W). NUP 3542 (1 alc, 65.4 mm), Mato Grosso, Santo Antônio do Leverger, rio Cuiabá, tributary of rio Paraguay (1558’27"S 5556’27"W). Oxydoras niger*. ANSP 179438 (3 sk, unmeasured), Perú, Loreto, Iquitos. MZUSP 9079 (1 alc, 550.0 mm), Amazonas, Manaus. MZUSP 13366 (1 alc, 315.0 mm), Pará, rio Tapajós. MZUSP 14019 (1 alc, 420.0 mm), Rondônia, rio Machado, rio Madeira basin. MZUSP 43466 ( 1 alc, 109.5 mm), Pará, Baião, rio Tocantins (250’S 4940’W). MZUSP 56162 (1 alc, 138 mm), Amazonas, rio Solimões (2³5’22"S 65³0’18"W). MZUSP 57320 (1 cs, 70.0 mm),

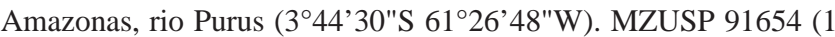
sk, $550.0 \mathrm{~mm}$ ), Goiás, Luís Alves, rio Verde, tributary of rio Araguaia (139'28"S 50³0’22"W). MZUSP 91658 (1 sk, 313.0 mm), Amazonas, Manaus, Porto Ceasa. Oxydoras kneri*. MZUSP 14847 (1 alc, $393.0 \mathrm{~mm}$ ), Mato Grosso, rio Paraguay at Ilha de Taiamã. Oxydoras sifontesi*. MZUSP 105824 (1 sk, 413.0 mm), Venezuela, Amazonas, Puerto Ayacucho. INHS 33986 (1 alc, 187 mm), Venezuela, río Orinoco ( $\left.8^{\circ} 6^{\prime} 0^{\prime \prime} \mathrm{N} 63^{\circ} 45^{\prime} 50^{\prime \prime W}\right)$. Platydoras armatulus*. ANSP 149463 (1 alc, 119.9 mm), Venezuela, Delata Amacuru, río Orinoco. ANSP 163478 (1 alc, 111.7 mm), Venezuela, Guarico, río Portuguesa, río Orinoco basin. ANSP 178748 (1 sk, unmeasured), Guiana, Rupununi River, tributary of Essequibo River. MZUSP 5645 (1 alc, 200.0 mm), Pará, Oriximiná, Lago Paru (152’S 5550’W). Pará, rio Trombetas. MZUSP 40577 (1 cs, 87.0 mm), Goiás, Iaciara, rio Paranã, rio Tocantins basin (146' $\left.6^{\prime} \mathrm{S} 46^{\circ} 38^{\prime} \mathrm{W}\right)$. MZUSP 86217 (1 cs, 52.5 mm), Mato Groso, Cocalinho, Corixo da Saudade, rio Araguaia basin (14²17’20"S 519'12"W). MZUSP 91686 (1 sk, 151.7 mm), Goiás, Minaçu, rio Tocantins. MZUSP 94088 (1 alc, $144.0 \mathrm{~mm}$ ), Mato Grosso, Gaúcha do Norte, rio Culuene, tribu- 
tary of rio Xingu (13³0’53"S 535'40"W). MZUSP 105041 (1 sk, $123.8 \mathrm{~mm}$ ), no data. Platydoras brachylecis. MZUSP 5122 (1 cs, 108 mm), Piauí, rio Parnaíba. MZUSP 110621 (1 sk, 223.0 mm SL), Pará, Altamira, rio Xingu (349’40"S 5241'31"W). Platydoras sp.* MPEG 6713 (1 cs, 107.0 mm), Pará, Altamira, rio Xingu. Pterodoras granulosus*. ANSP 178799 (2 sk, unmeasured), Argentina, Buenos Aires, río de La Plata (3453’S 589’W). ANSP 179166 (1 sk, unmeasured), Amazonas, rio Solimões. MZUSP 5681 (1 cs, 203 mm), Pará, Oriximiná, rio Trombetas (152’S 5550’W). MZUSP 38177 (1 sk, 220 mm), Mato Grosso, Barão de Melgaço, rio Cuiabá (16¹1'S 5557’W). MZUSP 82343 (1 alc, 435.0 mm), no data. MZUSP 82995 (1 cs, 60.5 mm), Amazonas, rio Amazonas. MZUSP 83317 ( 1 alc, 143.3 mm), Amazonas, rio Amazonas (3¹3’47"S 58³2’51"). MZUSP 89624 (2 sk, 208.0-262.0 mm), Mato Grosso do Sul, rio Cuiabá. MZUSP 91441 (1 alc, 330.0 mm), Amazonas, Nova Olinda do Norte, rio Madeira. MZUSP 91655 (8 sk, 260.0410.0 mm), Goiás, Minaçu, rio Tocantins at Serra da Mesa. Pterodoras rivasi*. ANSP 177895 (1 alc, 336.1 mm), Colombia, Lago Mozambique, río Meta, río Orinoco basin. MZUSP 88609 (1 alc, $82.2 \mathrm{~mm}$ ), Venezuela, Bolivar, río Guariquito, río Orinoco basin (7³9’36"N 66²0’0"W). MZUSP 105825 (1 sk, 350.0 mm), Venezuela, Amazonas, Puerto Ayacucho, río Orinoco $\left(5^{\circ} 40^{\prime} \mathrm{S}\right.$ 67³8’W). MZUSP 105830 (2 sk, 114.0-147.0 mm), Venezuela, Bolivar, Caicara del Orinoco, río Orinoco (7³8’45"N 66¹0’46"W). Rhinodoras boelhkei*. MZUSP 56895 (1 cs, 31.0 mm), Amazonas, rio Solimões ( $\left.3^{\circ} 35^{\prime} \mathrm{S} 61^{\circ} 5^{\prime} \mathrm{W}\right)$. MZUSP 86812 (1 alc, $95.0 \mathrm{~mm}$ ), Amazonas, rio Solimões (336’16"S 61²1'12"W). MZUSP 86814 ( 1 alc, 41.0 mm, 1 cs, 54.0 mm), Amazonas rio Solimões ( $3^{\circ} 26^{\prime} 22^{\prime \prime S}$ 6120'14"W). Rhinodoras cf. boelhkei. INPA 508 (1 cs, 69.0 mm), Pará, Tucuruí, rio Tocantins (342’S 3942’W). INPA 22056 (1, 36.9 mm), Pará, Tucuruí, rio Tocantins (342’S 3942’W). Rhinodoras dorbignyi*. ANSP 179535 (1 alc, 194 mm), Rio Grande do Sul, São Borja, rio Uruguai (28³8'S 56²' W). MZUSP 9381 (1 cs, 94.0 mm), São Paulo, rio Paraná (2043’S 51³7’W). MZUSP 27724 (1 alc, $207.7 \mathrm{~mm}$ ), Mato Grosso do Sul, Coxim, rio Taquari, tributary of rio Paraguay (18³0’S 56²0’W). MZUSP 40109 (1 sk, 196.0 mm), Rio Grande do Sul, São Borja, rio Uruguai (28³8'S 564'W). MZUSP 56750 (1 alc, 200.0 mm, 1 cs, 115.4 mm), Mato Grosso, Nobres, rio Cuiabazinho, rio Paraguay basin (1444's 56²0’W). MZUSP 61456 (2 cs, 70.4-121.9 mm), São Paulo, Pirassununga, rio Mogi Guaçu,

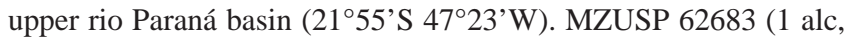
185.6 mm, 8 cs, 45.3-89.9 mm), São Paulo, Ilha Solteira, rio Paraná (20¹5'S 51ำ'W). MZUSP 78461 (1 alc, 168.0 mm), Rio Grande do Sul, rio Uruguai. Rhinodoras gallagheri. AMNH 58349 (1 cs, 52.4 $\mathrm{mm}$ ), Venezuela, río Apure, tributary of río Orinoco. Rhinodoras thomersoni*. MHNLS 0109 (1 cs, 60.9 mm), Venezuela, Lago Maracaibo. Rhynchodoras castilloi*. ANSP 181181 (1 alc, 58.3 mm), Venezuela, Portuguesa, Barinas, Caño Bravo, río Orinoco basin $\left(8^{\circ} 0^{\prime} \mathrm{N}\right.$ 6759’W). MZUSP 88604 (2 alc, 39.1-60.6 mm, 1 cs, 45.5 mm), Venezuela, Portuguesa, Barinas, Caño Bravo, río Orinoco basin $\left(8^{\circ} 0^{`} \mathrm{~N}\right.$ 6759’W). Rhynchodoras woodsi*. ANSP 181042 (1 alc, 72.5 mm, 1 CS, 88.4 mm), Perú, río Amazonas. MZUSP 56859 (1cs, 26.0 mm), Amazonas, rio Solimões ( $3^{\circ} 35^{\prime} \mathrm{S} 61^{\circ} 7^{\prime} \mathrm{W}$ ). MZUSP 56872 (3 alc, 22.5-37.3 mm, $1 \mathrm{cs}, 23.1 \mathrm{~mm}$ ), Amazonas, rio Amazonas ( $3^{\circ} 20^{\prime} \mathrm{S}$ 58³6’W). MZUSP 57316 (42.6 mm), Amazonas, rio Amazonas (3²0’28"S 58³6’25"W). MZUSP 57992 (2 alc, 35.0-45.0 mm), Amazonas, rio Amazonas ( $3^{\circ} 20^{\prime}$ 'S 58 $35^{\circ}$ 'W). MZUSP 86815 (1 cs, $48.2 \mathrm{~mm}$ ), Amazonas, rio Amazonas (3²0'9"S 58³6'11"W). ROM 62601 (1 alc, $44.2 \mathrm{~mm}$ ), Guiana, Essequibo river (440’S 5840’ W). Rhynchodoras xingui. SMF 5282 (1 alc, $44.5 \mathrm{~mm}$ ), upper rio Xingu. INPA 26540 (2 alc, 62.8-64.2 mm), Pará, Tucuruí, rio Tocantins (342'S 4942'W). Scorpiodoras heckelii*. MZUSP 84743 (2 alc,
138.0-145.0 mm), Amazonas, Santa Isabel do rio Negro, rio Negro. MZUSP 7941 (2 cs, 36.6-76.6 mm), Amazonas, Terra Santa, rio Jamari, rio Amazonas basin. MZUSP 8493 (1 sk, 114.4 mm), Pará, Santarém, rio Mapiri (2²6’'S 54²44'W). MZUSP 84203 ( 1 alc, 148.0 mm), Pará, Lago Jacupá, rio Amazonas basin. Tenellus leporhinus*. MZUSP 96596 (3 cs, 42.0-43.0 mm), Mato Grosso, Peixoto de Azevedo, rio Teles Pires, tributary of rio Tapajós (10¹3’14"S 5458’2"W). MZUSP 95617 (2 alc, 89.0-138.1 mm), Mato Grosso, Paranaíta, rio Teles Pires, tributary of rio Tapajós (9²7’7"S 56³0’46"W). MZUSP 88612 (1 alc, 75.3 mm, 1 cs, $73.8 \mathrm{~mm}$ ), Venezuela, Amazonas, río Ventuari, tributary of río Orinoco (445’0"S 66²1'13"W). MZUSP 105832 (1 sk, 97.2 mm), Venezuela, Bolivar, río Caura, río Orinoco basin (7²’37"S 6457’41"W). Tenellus ternetzi*. ANSP 179587 (2 sk, unmeasured), Amazonas, rio Negro (142’4"S 61²9’1"W). MZUSP 56694 (1 sk, 76.5 mm), Pará, rio Trombetas (149’27"S 5548’58"W). MZUSP 57273 (1 alc, 67.8 mm, 2 cs, 51.6-56.7 mm), Pará, Monte Dourado, rio Jari (043’7"S 52²9’43"W). MZUSP 76422 (2 alc, 98.4-117.2 mm, 1 cs, 111.2 mm), Pará, Santarém, rio Tapajós (2²3’S 5446’W). MZUSP 57682 (1 alc, 110.9 mm), Pará, rio Tapajós (240’41"S 558'48"W). MZUSP 103246 (5 sk, 63.4-91.4 mm), Pará, Monte Dourado, rio Jari (041’28"S 52³0’44"W). MZUSP 105833 (1 sk, $87.6 \mathrm{~mm})$, Venezuela, Bolivar, río Caura, tributary of río Orinoco $\left(7^{\circ} 2^{\prime} 37^{\prime} \mathrm{N}\right.$ 6457’41"W). MZUSP 110598 (1 sk, 95.0 mm SL), Pará, Porto de Moz, 146’9"S 52¹3'55"W). Tenellus trimaculatus*. MZUSP 29030 (1 cs, 51.3-56.0 mm), Rondônia, rio Madeira (8³’S 6253’W). MZUSP 52314 (1 alc, 83.8-84.4 mm), Mato Grosso, Araguaiana, rio Araguaia. MZUSP 53834 (1 alc, 75.6 mm), Mato Grosso, Araguaiana, rio Araguaia. MZUSP 56706 (1 alc, 46.9 mm), Amazonas, rio Jutaí (256’41"S 670’52"W). MZUSP 57272 (1

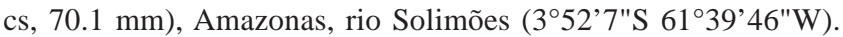
MZUSP 62656 ( 1 alc, 72.8 mm), Amazonas, Fonte Boa, rio Solimões (2³1'S 666'W). MZUSP 92206 (1 alc, 93.9 mm), Amazonas, rio Tiquié, rio Negro basin $\left(0^{\circ} 8^{\prime} 40^{\prime \prime} \mathrm{N} 69^{\circ} 12^{\prime} 48^{\prime \prime} \mathrm{W}\right)$. Trachydoras brevis*. MZUSP 29075 (1 cs, 33.0 mm), Rondônia, rio Machado, rio Madeira basin. MZUSP 55840 (1 cs, $43.9 \mathrm{~mm}$ ), Amazonas, rio Jutaí (253’26"S 6657’55"W). MZUSP 56713 (1 alc, 66.1 mm), Amazonas, rio Jutaí (257’22"S 670’28"W). MZUSP 93094 (1 alc, $93.7 \mathrm{~mm})$, Amazonas, Igarapé Castanha, rio Negro basin $\left(0^{\circ} 11^{\prime} \mathrm{N}\right.$ 69³5’W). MZUSP 93374 ( 1 alc, 46.5 mm), Amazonas, rio Tiquié, rio Negro basin (08’40"N 69¹2’41"W). MZUSP 103087 (5 sk, 70.0-74.0 mm), Pará, Monte Dourado, rio Jari (041’28"S 52॰30’44"W). Trachydoras microstomus*. MZUSP 56702 (1 cs, 49.8 mm), Amazonas, rio Jutaí (251'6"S 6658'7"W). MZUSP 57331 (1 cs, 57.5 mm), Pará, rio Amazonas (1²7’52"S 52³’13"W). MZUSP 57703 (3 alc, 43.6-76.6 mm), Amazonas, Manaus, rio Negro (3॰6'8"S 60¹0’2"W). MZUSP 105831 (1 sk, 50.0 mm), Venezuela, Bolivar, río Caura, tributary of río Orinoco $\left(7^{\circ} 2^{\prime} 37^{\prime \prime N} \mathrm{~N}\right.$ 6437’41"W). Trachydoras nattereri*. MZUSP 7837 (2 cs, 55.458.5 mm), Pará, Faro Nhamundá, Paraná do Jacaré, rio Amazonas basin. MZUSP 55854 (1 alc, 48.7 mm), Roraima, Caracaraí, rio Negro (1¹8’51"S 6155’21"W). MZUSP 31703 (1 alc, 99.3 mm), Roraima, Caracaraí, rio Negro (1¹8’51"S 6155’21"W). Trachydoras paraguayensis*. ANSP 178699 (1 alc, $79.2 \mathrm{~mm}$ ), Mato Grosso, Cácares, rio Paraguay. MZUSP 21109 (1 alc, 80.2 mm), Paraná, Bandeiras, rio Paraná (24¹0’S 54¹9’W). MZUSP 27801 (1 alc, 84 mm), Bolívia, Santa Cruz, Laguna San José, rio Madeira basin. MZUSP 29047 (1 alc, $115.1 \mathrm{~mm}$ ), Rondônia, Calama, rio Madeira (8³’S 6253’W). MZUSP 40081 (1 alc, 101.0 mm), Mato Grosso do Sul, Aquidauana, rio Aquidauana, rio Paraguay basin (20²8'S 5548’W). MZUSP 48315 (1 cs, $54.3 \mathrm{~mm}$ ), Mato Grosso

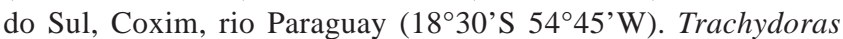


steindachneri*. ANSP 179171 (1 sk, unmeasured), Amazonas, rio Solimões (254'15"S 6747’53"W). MZUSP 7611 (1 cs, 75.8 mm, 1 sk, $63.6 \mathrm{~mm})$, Amazonas, Urucará, Paraná do Mocambo, rio Amazonas basin (2³7'S 57²3’W). MZUSP 7836 (1 cs, 70.0 mm), Pará, Faro Nhamundá, Paraná do Jacaré. MZUSP 62696 (3 alc, 38.7-77.0 mm), Amazonas, Fonte Boa, rio Solimões ( $2^{\circ} 31^{\prime} \mathrm{S}$ 666’W). MZUSP 74867 ( 1 alc, 75.7 mm), Amazonas, rio Solimões. Wertheimeria maculata*. MCZ 91317 (1 cs, 65.0 mm), Minas Gerais, Itira, rio Jequitinhonha (16² $46^{\prime}$ S $42^{\circ} 2^{\prime}$ W). MZUSP 40229 (10 alc, 46.7-145.0 mm, 3 cs, 25.0-112.0 mm), Minas Gerais, Itira, rio Jequitinhonha (16² $47^{\prime} \mathrm{S} 42^{\circ} 3^{\prime}$ 'W). MZUSP 88614 (1 sk, 124.0 $\mathrm{mm}$ ), Minas Gerais, rio Jequitinhonha. MZUSP 93659 (2 sk, 195.0217.0 mm), Minas Gerais, Araçuaí, rio Jequitinhonha. MZUSP 93658 (1 alc, $168.0 \mathrm{~mm}, 1 \mathrm{sk}, 192.0 \mathrm{~mm}$ ), Minas Gerais, Itira, rio Jequitinhonha (16² $\left.45^{\prime} 44^{\prime \prime S} 42^{\circ} 0{ }^{\prime} 37^{\prime \prime} \mathrm{W}\right)$. Erethistidae. Conta conta*. USNM 44759 (1 cs, 52.0 mm), Myanmar, Meetan. Heptapteridae. Rhamdia quelen. MZUSP 36505 (1 alc, 170.0 mm), São Paulo, rio Ribeira de Iguape. MZUSP 79083 (1 sk, 233.0 mm), Paraná, Represa de Vossoroca, upper rio Paraná basin. MZUSP 102800 (1 sk, 160.0 mm), São Paulo, Biritiba Mirim, rio Tietê, upper rio Paraná basin (2334'5"S 460'38"W). Goeldiella eques*. MZUSP 33190 (1 cs, 103.5 mm), Amazonas, rio Negro. MZUSP 45907 (1 cs, 79.0 mm), Pará, rio Trombetas. Ictaluridae. Ictalurus punctatus*. MZUSP 62602 (1 cs, unmeasured), no data. MZUSP 103256 (1 cs, 50.0 mm, 1 sk, 155.0 mm), no data. Malapteruridae. Malapterurus beninensis*. MZUSP 84464 (2 alc, 64.2-69.6 mm, 2 cs, 30.6-64.2 mm), Benin, Quémé, Azowlissé, Quémé river (140’29"N 2²9'15"E). Mochokidae. Chiloglanis disneyi*. USNM 303505 (3 cs, 50.5-53.7 mm), Camaroon, Akpa-Yafe basin, SW Korup. Chiloglanis paratus. MZUSP 65810 (3 alc, 60.5-61.3 mm), South Africa, Mabunga Rapids. Chiloglanis polypogon. USNM 304264 (4 cs, 25.3-28.9 mm), Camaroon, Munaya River. Euchilichthys guentheri. AMNH 6507 (2 alc, 183.5-221.0 mm), Congo, Orientale Province, Stanleyville. Microsynodontis christyi. ZSM 22895 (1 cs, 29.8 mm), Congo, Stanley-Pool, Leopoldville. Microsynodontis batesii. SU 47485 (2 alc, 51.4-53.8 mm), Camaroon, Congo river. Mochokiella paynei*. AMNH 58398 (1 alc, 36.7 mm, $1 \mathrm{cs}, 38.0 \mathrm{~mm}$ ), Aquarium store. Mochokus brevis. CAS 211322 (1 alc, $21.7 \mathrm{~mm}$ ), Egito. Mochokus niloticus*. USNM 229657 (1 cs, $28.8 \mathrm{~mm}$ ), Nigeria. Synodontis batensoda*. AMNH 230635 (2 alc, 54.1-62.8 mm), no data. MNHN 1959-525 (1 cs, 48.4 mm), Tchad, Kousseri, Lake Tchad. Synodontis membranaceus. USNM 313407 (1 cs, $50.3 \mathrm{~mm}$ ), Gana, White Volta. Synodontis nigriventris. MZUSP 59326 (1 cs, 39.8 mm), no data. Synodontis schall*. ANSP 78057 (1 sk, unmeasured), Egito, Sudan, Khartoum. MZUSP 84468 (2 alc, 63.1-76.0 mm, 8 cs, 43.0-80.0 mm), Benin, Quémé, Azwlissé, Quémé river (140’29"S 2²9’15"E). Synodontis sorax. ANSP 78053 (1 sk, unmeasured), Egito, Sudan, Khartoum. Synodontis zambezensis. MZUSP 62621 (2 cs, 45.7-52.7 mm), South Africa, KwaZulu, Natal Phongola, Ngodo pan. Nematogenyidae. Nematogenys inermis*. MZUSP 75256 (1 sk, 210 mm), Chile, Águas de La Gloria, Estero Águas de La Gloria (3650’30"S 7256’4"W).

Pangasiidae. Pangasius pangasius*. MZUSP 62587 (1 alc, 130 mm), Myanmar, Thanlyin. Pangasius sutchi. MZUSP 102779 (2 cs, 56.4-61.0 mm), no data. Pangasius sp. MZUSP 60075 (1 cs, $45.1 \mathrm{~mm}$ ), no data. Pimelodidae. Steindachneridion scriptum. MZUSP 90279 (6 cs, 19.0-23.0 mm), Santa Catarina, rio Uruguai. Steindachneridion parahybae*. MZUSP 100672 (1 sk, 329.0 mm, 4 cs, 74.8-93.7 mm), São Paulo, rio Paraíba do Sul. Pseudopimelodidae. Pseudopimelodus bufonius*. MZUSP 94855 (1 alc, 168.0 mm, 1 cs, 68.0 mm, 2 sk, 170.0 mm), Mato Grosso

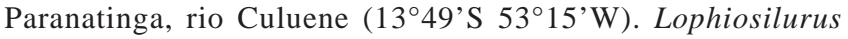

alexandri. MZUSP 73817 (1 alc, 127.8 mm), Minas Gerais, Presidente Jucelino, rio Cipó (1841’4"S 4359’18"W). Siluridae. Wallago attu*. BMNH 1889.9.26.48-50 (1 cs, 175.0 mm), Deola, Rajputana. Sisoridae. Bagarius bagarius*. USNM 186793 (1 cs, $98.5 \mathrm{~mm})$, Thailand, Ubon.

\section{Acknowledgements}

The manuscript greatly benefited from comments and suggestions of Carl Ferraris and Mark Sabaj Pérez. For loans and exchanges of specimens, for their hospitality during visits to the fish collections under their care, and exchange of information and ideas, I thank Roberto Reis, Carlos Lucena, and Margarete Lucena (MCP), Marcelo Britto and Paulo Buckup (MNRJ), Lucia Rapp Py-Daniel, Jansen Zuanon, Renildo Oliveira, and Marcelo Rocha (INPA), Angela Zanata and Priscila Camelier (UFBA), Luiz Malabarba (UFRGS), Carla Pavanelli, Claudio Zawadzki, and Weferson da Graça (NUP), Julio Garavello and Alexandre K. Oliveira (UFSCar), Fernando Jerep and Oscar Shibatta (MZUEL), Osvaldo Oyakawa, Mario de Pinna, and José Lima de Figueiredo (MZUSP), John Lundberg, Mark Sabaj Pérez and Kyle Luckenbill (ANSP), Dave Catania and Tomio Iwamoto (CAS), Jonathan Armbruster and Nathan Lujan (AUM), John Friel (CU), Mary Anne Rogers and Kevin Swagel (FMNH), Scott Schaefer (AMNH), Richard Vari (USNM), Karsten Hartell and Andrew Williston (MCZ), Donald Taphorn, Otto Castillo and Oscar León (MCNG), Hernán Ortega, Vanessa Meza and Max Hidalgo (MUSM), Ralf Britz, James Maclaine, and Oliver Crimmen (BMNH), Helmut Wellendorf (NMW) and Patrice Pruvost (MNHN). Thanks are due to Mark Sabaj Pérez, Leandro Sousa and Mariangeles Arce for sharing their expertise on doradids, to Heraldo Britski for his advisory role during my Ph.D. studies, to Marcelo Britto, Mario de Pinna, Alberto Akama, and Naércio Menezes for their important criticisms as my Ph.D. committee, and to Cristiano Moreira, Flávio Lima, Fabio Di Dario, Alberto Akama, Leandro Sousa, and André Netto Ferreira for discussions during the development of this study, help with cladistic computer programs and preparations of images. This is part of my Ph.D. studies developed at the Museu de Zoologia da Universidade de São Paulo, from which I thank all the staff, especially the students and visitors of the Seção de Peixes and the librarians of the MZUSP. I received several grants during the development of this study, including FAPESP(06/53737-7), PROAP-CAPES (2007), CAS (Lakeside Grant, 2009), ANSP (Böhlke Award, 2010), and the All Catfish Species Inventory (NSF DEB-0315963). 
Table 1. Phylogenetic character matrix. Missing data or characters inapplicable to particular taxa are indicated by “?”; polymorphic characters indicated by A for $(0,1)$, B for $(1,2)$, and $\mathrm{C}$ for $(2,3)$.

OUT-GROUP

Amphiliidae

000000000000000020?00001000000000000?0?000000000000100000001 $101000000000000000010000 ? 2001100000000000020000000000000000$ ? ????0000000011000010000000110010A00?000000201001100100011110 0111000000000000011000?000?0??010000010012200001???01101?010 $000000000000010000 ? 100000100 ? 1000100011000100000000000000000$ 00020300112

Ariidae(Galeichthys)

000000310000000020?01000?00000000000?0?010000000000100000001 $100000000000001100010000 ? 1000000000000000030000000000310000$ ? ????0000000011000000010001110011000?010000200010000000000010 $0001000000000000011000 ? 000 ? 0 ? ? 010000010002200000000000000010$ $0010000000100120010000000100 ? 10000 ? 0011000000001000000000000$ 00020100011

Ariidae(Genidens)

000002310000000020?01000?00000000000?0?010000000000100000011 $100000000000000100011000 ? 2000000000000000030000000000310000$ ? ????0000000011000000011001110011000?010000200010000000000010 $0001000000000000001000 ? 001 ? 120010000130002200000000000000010$ $0010010000100120010000000100 ? 10000 ? 0011000000001000000000000$ 00020210011

Aspredinidae

00001?200000000020?00001000000000000?0?000000000000110001001 000000000000000000011000?0??101100000000003000000001??00000? ????00002??011000000000000110010000?000010101000000100000010 022??00000011000111000?000?0??02000111001200000000001101?010 $0000000000100000010000000100 ? 11010 ? 00100000 ? 0000000000000000$ 00010300122

Claroteidae

000000000000000020?00010?00000000000?0?000000000000100000001 100000000000001100011000?0??0000000000000020000000000300000? ????00100000110000000100011100110010010000101?10000000000110 0111000000000000001000?000?0??010000010001100000000000000010 $0000010000000010010000000100 ? 10000 ? 0011000000001000000000000$ 00010110021

Diplomystidae

00000011000000000?????00?00000000000?0?000000000000000000000 100000000000011000000000?0??0000000000000000000000000200000? ????000000000000000000000000010000100000000000A1100000000100 0001000000000000000000?000?0??010000000002100000000000000010 $000000000000000000 ? 000000100 ? 00000 ? 0000000000001000000000000$ 00000010000

Erethistidae

$000000110000000020 ? 00011100000000000 ? 0 ? 00000000000100000021$ 000000000000000000011000?0??111100000000003000000001??00000? ????0000000011000000000000110010000?000000200001100000001010 0111000000011000111000?000?0??020001110012000000100011001010 $000001000000000000 ? 000000100 ? 1100100011000100001000000000000$ 00020110122

Heptapteridae

000000000000000020?00000?00000000000?0?010000000000100000020 $100000000000000000010000 ? 0 ? ? 0000000000000020000000000200000$ ? ????0011000011000000000000110010000?000000101000100000000110 0111000000000000011000?000?0??010000010002200000000000000010 $0000000000000000010000000100 ? 10000 ? 0011000000101000000000000$
00020110011

Ictaluridae

000002000000000020?00010?00000000000?0?000000000000000000001 100000000000000000010000?0??0000000000000000000000000200000? ????00000000110000000000001100100010010000100001100000000110 0111000000000000011000?000?0??010000010002200000000000000010 $0000000000000000010000000100 ? 10000 ? 0201000000002000000000000$ 00000110000

Malapteruridae $000000200000000020 ? 00000 ? 00000000000 ? 10000000000000000000020$ $001000000100010000010000 ? 0 ? ? 0000000000000020000000000300000$ ? ????0000000011001?10001001110010100?000000101001100000000110 0111000000000000011000?002?12001000001000B100001??????1??1? ?????????001?00000?1000000???10000?0010000000000000000000000 20020200011

Mochokidae(Chiloglanis)

000000200000000020?00001000000000000?0?000000000000110000021 $100000001000000000011000 ? 100110000000000002000000001 ? ? 00000 ?$ ????0200011011001?11100010110010100?000000000000010100001010 0111000000000000011000?00201100201?01200010000001??100101110 000000000000012000?100000100?1000100101000100001000000000000 00020110022

Mochokidae(Mochokiella)

$000000200000000021000000 ? 00000000000 ? 0 ? 000000000000100000021$ 100000101000000000011000?1001100000000000030000000000000000? ????0000000011001?11000000110010000?001000000?00010000001010 $0111000000000000011000 ? 00201100101 ? 0020001000000011000101010$ $0000010000000010010000000200 ? 1000100111000000001000000000000$ 00020200022

Mochokidae(Mochokus)

$000000200000000021000000 ? 00000000000 ? 0 ? 000000000000100001011$ $100000001000000000011000 ? 1001100000000000030000000000000000$ ? ????0000000011001?11000000110010000?000000100?00010000001010 $0111000000000000011000 ? 00201100101 ? 0020000000000011000101010$ $0010000000000000010000000200 ? 1000100111000000001000000000000$ 00020300022

Mochokidae(Synodontis)

000000200000000021100000?00000000000?0?000000000000110000021 $100000101000000000011000 ? 1001100000000000030000100000000000$ ? ????0200011011001?11100010110010000?001000000000010000001110 $0111000000000000011000 ? 0020110010110020001101000010000101010$ $0000010000000010010000000200 ? 1000110100000000001000000000000$ 00020110022

Nematogenyidae

00001?000000000010??0?00?00000000000?0?000000000000000000000 000000000000010000000000?0??1100000000000000000000000200000? ????00000000110000100000001000000010000000000001100000000200 0111000000001000011000?000?0??010000000002100001???00001?010 000000000001?00000?0000000???00000?0011000000001000000000000 $000 ? 0200000$

Pangasiidae

000002000000000010??0?10?00000000000?10000000000000100000000 $100000000000001100010000 ? 1000000000000000010000000000210000$ ? ????00000000110000000000001100100010010000100010100000000210 $0111000000000000000000 ? 002 ? 120010000020002100000000000000010$ $0000010000000010010000000100 ? 10000 ? 0301000000003000000000000$ 00000110000

Pimelodidae

000000000000000020?01000?00000000000?0?010000000000100000021 100000000000001000010000?0??0000000000000030000000000310000? ????0011000011000000000000110010000?010000100010100000000110 
0111000000000000011000?000?0??010000020002200000000000000010 $0000000000000000010000000100 ? 10000 ? 0011000000001000000000000$ 00020110001

Pseudopimelodidae

000000000000000020?00000?00000000000?0?000000000000100000020 000000000000000000010000?0??0000000000000030000000000300000? ????00110000110000000000001100100010000000100010000100000110 0111000000000000011000?000?0??010000010001000000000000000010 $0010010000000000010000000100 ? 10000 ? 0011000000000000000000000$ 00020210112

Siluridae

00001?000000000020?00000?00000000000?0?000000000000100000001 $100000000000001000010000 ? 0 ? ? 1000000000000020000000000300000$ ? ????0000000111000010000000110010000?000000100001000000000210 0001012000000000011000?000?0??010000020001200001???00001?010 000000000000000000?0000000???00000?0301000000003000000000000 $000 ? 0110000$

Sisoridae

000000110000000020?00011100000000000?0?000000000000100000021 $00000000000000000011000 ? 100011100000000001000000001 ? ? 00000$ ? ????0010000111000000000000110010000?000000100011100100001010 0111000000100000011000?000?0??020001010011000000100011001010 $000000000000000000 ? 000000100 ? 11000 ? 0000000100001000000000000$ 00020110022

INGROUP (Auchenipteridae)

Ageneiosus atronasus

00000220001001100?????00?00000000000?0?200012020001110000021 00110000100001000001101112011100100101100030000000000201100 ? ????00000000110100000000001100100011000100111001111000010110 $0001010000110001011000 ? 11301011001001301111101001 ? ? 100101011$ $111010001010000110 ? 0000000 ? ? ? 1000100111000010002000000000001$ 00020110012

Ageneiosus inermis

$00000220001001100 ? ? ? ? ? 00 ? 00000000110 ? 0 ? 200012020001110000121$ 00110000100001000001101112011100100101100030000000000201100 ? ????00000000110100000000001100100011000100111001111000010210 $0001010000110001011000 ? 113210010010013011 B 2101001 ? ? 100101011$ $111110002010000110 ? 0000100 ? ? ? 1000100111000010003000000000001$ 10020110012

Asterophysus batrachus

000002200000011020?00000?00000000000?0?001110120001110000021 00001000100100000001101102001100000101000030000000000301110 ? ????00000000110000010000001100100011000000200001110000000110 $0000000100010000011200 ? 1130100100100130112100000010000101010$ $0010010002100000010000000200 ? 1000100311000000100000000000000$ 00020110112

Auchenipterichthys thoracatus

000002200000011020?00000?00000000000?10000011020001110000121 00001000100000000001101112001100000101000030000000000201010 ? ????00000000110000000000001100100011000100200001110000000110 $000000000110000011000 ? 1130100100100140111100000010000101010$ $0010011000100000010000000200 ? 1101100311000000102000000000001$ 10020111012

Auchenipterus nuchalis

000002200000011020?11100?11010000000?0?000012021001100000221 00011000110000001011101112011100100111100030000011100201100 ? ????00011001111000000011001100100011000010200001110000000110 $0112002000100000011000 ? 1130100100100030111200000010000101010$ $010000000010000000 ? 000100200 ? 12000 ? 0311001021013000010010001$ 00021110012
Centromochlus heckelii 000002200000011020?00000?0000000000100?000010110000110000A20 $00000000100000000111101111001100000101100030000000000201010 ?$ ????00000001110000000000001100100011000100111001110000000010 $0111000000010000011000 ? 1131101100100$ A4011B100000010000101120 $0010010002100000011001000200 ? 1001100011000000100110201000000$ 00020110012

Entomocorus radiosus

000002200000011020?01000?11100000000?0?00001??20001100000021 $00010000101000000001101112001100000101100030000011100201 ? 00$ ? ????00001001111000000011001100100011000010200001110000000110 $0111000000100000011000 ? 1130100100100130111100000010000101111$ $0100010002101000010000000200 ? 1000100011100001012000000000001$ 00021110112

Epapterus dispilurus

00001?200000011020?11100?11010000000?0?00001??21011100000021 00011000110000000001101112011100100111100030000011100201100 ? ???:00012??1111000000012001100100011000010200001110000000110 $0112002000100000011000 ? 11301001001000301102000001 ? ? 100101301$ 01000000?010000000?000100200?12000?03110010210?3000010000001 00021110012

Gelanoglanis cf. stroudi

000002200000011010??0?00?00000000000?0?00001??1000010000?021 $0000000010001 ? ? 00101101111001100000101000030000000001200000 ?$ ????00000001110000000000001100100011000000100001110000000010 022????000010000011000?113010?1101001101110000001??100101110 $00000000 ? 210000000 ? 000000100 ? 1000100011000010100111200000000$ 00020110012

Glanidium melanopterum

000002200000011020?00000?00000000000?0?000011010001110000021 $000100001000000001011011110011000001010000 \mathrm{C} 0000000000200010$ ? ????00000000110000000000001100100011000100100001110000000010 $0111000000000000011000 ? 1130100100100130112100000010000101110$ $0000000000100000010000000100 ? 1000100011000000 ? 01110100000000$ 00020110012

Liosomadoras oncinus

000002200000011020?00000?00000000000?0?000011020001110100121 00001000100000000001101101001100000101000030001000000201010 ? ????00000000110000000000001100100011000100100000110000000110 $0000000000110000011000 ? 1130100100100 A 30111100000010000101011$ 011001000010000001000000020101000100111000000100000000000000 00020110012

Pseudauchenipterus affinis

000002200000011020?01000?00001000000?0?000011020101110000020 1000000010000000010110111200110000010100003000000000201010 ? ????00000000110000000000001100100011000100100001110000000110 $0000000000110000011000 ? 1130100100100130111100000010000101010$ $000001000210000000 ? 000000200 ? 1000100211000000102000000000001$ 00020110012

Pseudepapterus cucuhyensi

$000002200000011020 ? 11100 ? 11010000000 ? 0 ? 000011021001100000021$ 00011001100000001001101112011100100111100030000011100201100 ? ????00002??:1111000000012001100100011000010200001110000000110 $0112001000100000011000 ? 11301001001001201102000001 ? ? 100101100$ $010000002010000000 ? 000100200 ? 22000 ? 0311001021013000010000001$ 00021110012

Pseudotatia parva

000002200000011020?00000?????0000??????????1??2????110000020 ?00000001000000001011011120011000001010000?0000000000?01?10? ????0000000011??00000000001100100011000100100001110000000?10 
0??????000?10000011000?113010?10010003011110000001000010101? ??1??0?0?2100000010000000200?1000100111?00000?0100000???000? 00020110012

Spinipterus acsi 000002200000011020?00000?????0000??????????1??2????110101021

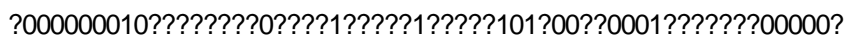

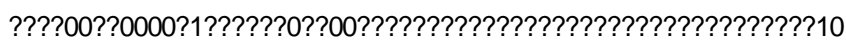

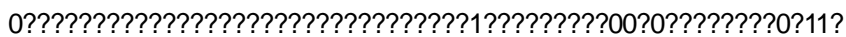

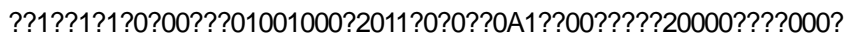
100??12????

Tatia aulopygia 000002200000011020?00000?00000000000?0?000010110000110000A21 00000000100000A00101101111001100001101000030000000000200010? ????0000000011000000000000110010001100010020A001110000000010 0111000000010000011000?1130100100100A30111100000010000101110 $0010000002100000010000000100 ? 1000100011000000100111200100010$ 00020110012

Tetranematichthys quadrifilis

000002200010011010??0?00?10000000000?10000011020001110000121 00110000100001000001101112011100100101100030000000000201100 ? ????00000000111000000000001100100011000100111001111000010210 0001110000110001011000?1130100100100130111B101001??100101011 $111001003010000100 ? 000100100 ? 1000100111000010003000000000001$ 10020121012

Tocantinsia piresi

000002200000011020?00000?00000000000?0?100011020001110000121 $00000000100000000001101111001100000101000030000000000 ? 01010$ ? ????00000000110000000000001100100011000100100001111000000110 $0111100000110000011000 ? 1130100100100140112100000010000101010$ $0000000000100000011000000200 ? 1000100111000000100000000000000$ 00020110012

Trachelyichthys decaradiatus

00001?200000011020?00000?00000000000?0?000011020001110001021 00000000100000000001101112011100000101000030000000000201010 ? ????00000000110000000000001100100011000100100001110000000110 $0000000000110000011000 ? 1130100100100130111100000010000101211$ $0010010000100000010000000200 ? 1000100311000000103000000000001$ 10020121012

Trachelyopterichthys taeniatus

00001?200000011020?00000?00000000000?0?000011020001110100121 00001000100000000001101112001100001101000030001000000301010 ? ????00000000110000000000001100100011000100200001110000000110 $0000000000110000011000 ? 1130100100100140111200000010000101211$ $0010011000100000010010000200 ? 1000100311000000103000000000001$ $100201 B 1012$

Trachelyopterus coriaceus

00001?200000011020?01000?00000000000?0?000011020001110100121 00001000100000000001101112011100000101000030000000000301110 ? ????00000000110000000000001100100011000101200001110000000110 $0110000000110000011000 ? 1130100100100140111100000010000101111$ $000001002010010000 ? 000000200 ? 1001100011000000102000000000001$ 10020121012

Trachelyopterus galeatus

000002200000011020?00000?00000000001A0?000011020001110100121 00001000100000000001101112001100001101000030000000000301110 ? ????00000000111000000000001100100011000101200001110000000110 0110000000110000011000?1130100100100140111B00000010000101111 $0000010020100100010000000100 ? 1000100011000000102000000000001$ 10020121012

Trachycorystes trachycorystes
$000002200000011020 ? 00000 ? 0000000000100 ? 100011020001110100121$ $000010001000000000011011 \mathrm{~A} 1001100001101000031001000000301110$ ? ????00000000110000000000001100100011000101200001110000000110 $0000000000110000011000 ? 1130100100100140111100000010000101110$ $0010000000100000010000000200 ? 1000100311000000102000000000001$ 00020110012

INGROUP(Doradidae)

Acanthodoras cataphractus

100002200000000020?00000?0000000000100?000000000000100000A21 OA0000001000000000011011010011000001010100311110000001000021 $01100000000011000000000000110010000 ? 000000200000110000000010$ $0111000000000000011000 ? 1130100101200110111000000010000101110$ 001000010010010001002000120121001110011000010001000000000000 20120100022

Agamyxis albomaculatus

100002200000000020?00000?0000000000100?100000000000100000121 010000001000000000011011010011000001010100311110000001000021 $01100000000011000000000000110010000 ? 000000200000110000000110$ $0111000000000000011000 ? 1130100101200110111000000010000101010$ 001000010010010001002000120101001100011010000001000000001100 01120200012

Anadoras grypus

001002201001000020?10100?00000100000?0?001000000000121010001 001000001000010000111011121011000101000010300001000000000021 100201002??111000100000100111010010?000000101100110011100111 112100101001010001110111131100101200130111101020010100101010 $0010010001100100010000001220 ? 1010100111000010001000000000000$ 00020110011

Anduzedoras oxyrhynchus

010002200000000020?00000?00000000000?0?000000000000100000121 000000001000000000011011020011000001010 A00200000000002000021 $00110000000011000000000000110010000 ? 000000100000110000000110$ $0111001000000000011000 ? 1130100101200110111001000010000101010$ 00000000001001000100000012012100110011100000000100000000000 00020100012

Astrodoras asterifrons

$000002200000000020 ? 00000 ? 00000000001000000000000000100000021$ 000000001000000000011011020011000001010000300010000002000021 $01110000000011000000000000110010000 ? 000000100000110000000110$ $011100000000000011000 ? 1130100101200110111001000010000101010$ 001000000010010001000000120121101100111000000001000000000000 10020100012

Centrochir crocodili

010001200000000020?00000?00000000000?0?000000000000100000021 000000001000000000011011010011000001000100300000000002000021 00A10000000011000000000000110010000?000000100000110000000110 $0111000000000000011000 ? 1130100101200130111001000010000101010$ 001001000010010001000000120111000110111000000001000000000000 $000201100 ?$ ?

Centrodoras brachiatus

$000001200000000020 ? 0000100000000000 ? 10002000000000100000021$ 000000001000000000011011010011000001000100300000000001000021 $00110000000011000000000000111010000 ? 000000100000110000000110$ $0111000000000000011000 ? 1130100101200130112101000010000101010$ $0010010000100100010000001200 ? 1000110111000000001000000000000$ 00020110011

Centrodoras hasemani

$000001200000000020 ? 00001000000000000 ? 10002000000000100000021$ 000000001000000000011011010011000001000100300000000001000021 $00100000000011000000000000110010000 ? 000000100000110000000110$ 
$0111000000000000011000 ? 1130100101200130112101000010000101010$ $0010010000100100010000001200 ? 1000110111000000001000000000000$ 00020110011

Doraops zuloagai

000000200000000020?00000?00000000000?10012000000000110000021 $00000000100000000001101101001100000100000030000000000 ? 000011$ $00100000000011000000000000110010000 ? 000000100000110000000110$ $011100000000000011000 ? 1130100101200140112101000010000101010$ $0010010000100100010000001200 ? 1000100111000000001000000000000$ 00020110011

Doras carinatus

$000002200001000020 ? 10100 ? 00000110000 ? 11000000000000121010021$ 001000001000010000111011121011000101000010300001000000000021 $10010100100111000100000100111010010 ? 000000101100110011100111$ $1121000010000100011100 ? 1131100101200130111$ A01000010000101010 $0010010001100100010000001220 ? 1010100111000010001000000000000$ 00020110011

Doras higuchii

$000002200001000020 ? 10100 ? 00000110000 ? 11000000000000121010021$ 001000001000010000111011121011000101000010300001000000000021 $10010100100111000100000100111010010 ? 000000101100110011100111$ $1121000010000100011100 ? 1131100101200130111$ A01000010000101010 $0010010001100100010000001220 ? 1010100111000010001000000000000$ 00020110011

Doras phlyzakion

000002200001000020?10100?00000110000?0?100000000000121010021 001000001000010000111011120011000101000000300001000000000021 100101002??111000100000B00111010010?000000101100110011100111 $1121000010000100011100 ? 1131100101200130111001000010000101010$ $0010010001100100010000001220 ? 1010100111000010001000000000000$ 00020110011

Franciscodoras marmoratus

$000000200000000020 ? 00000 ? 00000000000 ? 0 ? 000000000000100000021$ 000000001000000000011011010011000001000000300000000002000021 001100000000110001000000001100100011000000100000110000000110 $011100000000000011000 ? 1130100101200110111001000010000101010$ $0010000000100100010000000200 ? 1000100011000000001000000000000$ 01020100012

Hassar affinis

001002200001000020?10100?00000100000?0?001000000000121010001 001000001000010000111111121011000101000010300001000000000011 $10010100100111000100000100111010010 ? 000000101100110011100111$ $1121000010000100011100 ? 1131100101200130111001010010100101010$ $0010010001100100010000001220 ? 1010100111000010001000000000000$ 00020110011

Hassar gabiru

001002200001000020?10100?00000100000?0?001000000000121010001 001000001000010000111111121011000101000010300001000000000011 $10010100100111000100000100111010010 ? 000000101100110011100111$ $1121000010000100011100 ? 1131100101200130111001010010100101010$ $0010010001100100010000001220 ? 1010100111000010001000000000000$ 00020110011

Hassar orestis

001002200001000020?10100?00000100000?0?001000000000121010001 001000001000010000111111121011000101000010300001000000000011 $10010100100111000100000100111010010 ? 000000101100110011100111$ $1121000010000100011100 ? 1131100101200130111001010010100101010$ $0010010001100100010000001220 ? 1010100111000010001000000000000$ 00020110011

Hemidoras morei
$000002200001000021010100 ? 0000000000100 ? 001000000000121010021$ 000000001000010000111011120011000101000000300011000000000021 100101002??111000100000200111010010?000000101100110011200111 $1111000010000100011100 ? 1131100101200130111001010010100101010$ $0010010001100100010000001200 ? 1011100111000020001000000000000$ 00020110011

Hemidoras morrisi

$000002200001000021010100 ? 0000000100100 ? 001000000000121010021$ 00000000100001000011101112001100010100000030001100000000021 100101002??111000100000200111010010?000000101100110011200111 $1111000010000100011100 ? 1131100101200130111$ A01010010100101010 $0010010001100100010000001200 ? 1011110111000020001000000000000$ 00020110011

Hemidoras stenopeltis

$000002200001000021010100 ? 0000000100100 ? 001000000000121010021$ 000000001000010000111011120011000101000000300011000000000021 $10010100100111000100000100111010010 ? 000000101100110011200111$ $1111000010000100011100 ? 1131100101200130111$ A01010010100101010 $0010010001100100010000001200 ? 1011100111000010001000000000000$ 00020110011

Hemidoras stubelii

$000002200001000021010100 ? 0000000000100 ? 001000000000121010021$ 000000001000010000111011120011000101000000300001000000000021 100101002??:111000100000100111010010?000000101100110011200111 $1111000010000100011100 ? 1131100101200130111001010010100101010$ $0010010001100100010000001200 ? 1011100111000010001000000000000$ 00020110011

Kalyptodoras bahiensis

000000200000000020?00000?00000000000?0?000000000000110000A21 000000001000000000011011010011000011000000311100000002000011 001100000000110001000000001100100021000000200000110000000110 $0111000000000000011000 ? 1130100101200110112100000010000101010$ $0010000000100100010000000200 ? 1000100011000000001000000000000$ 00020100012

Leptodoras juruensis

$000002201101000020 ? 10101000000000100 ? 0 ? 201000000000121010001$ 001000001000010000011011121011000101000010300001000000000021 100201002??111000100000B00111010010?000000101100110011100112 122????01001011001110121131100111200130110201010010000101010 001000?002100100010000001220?1010101111000000001000000000000 00020110011

Leptodoras marki

011002201001000020?10100?00000100000?0?001000000000121010001 001000001000010000111011121011000101000010300001000000000021 $100101002 ? ? 111000100000200111010010 ? 000000101100110011100112$ 112100101001011001110101131100101200130111101020010000101010 $0010010001100100010000001220 ? 1010101111000000001000000000000$ 00020110011

Leptodoras oyakawai

011002201001000020?10100?00000100000?0?000000000000121010001 001000001000010000111011121011000101000010300001000000000021 100101002??:111000100000200111010010?000000101100110011100112 112100101001011001110101131100101200130111101020010000101010 $0010010001100100010000001220 ? 1010101111000000001000000000000$ 00020110011

Leptodoras praelongus

011002201001000020?10100?00000100100?0?201000000000121010001 001000001000010000111011121011000101000010300001000000000021 100101002??111000100000B00111010010?000000101100110011100112 
112100101001011001110121131100101200130111101020010100101010 $0010010001100100010000000220 ? 1010101111000000001000000000000$ 00020110011

Lithodoras dorsalis

000000200000000020?00001000000000000?10012000000000110000021 000000001000000000011011010011000001010000311000000002000021 $00100000000011000000000000110010000 ? 000000100000110000010110$ 0111000000000000011000?1130100101200140112B01000010000101010 $0010010000100100010000001200 ? 1000100111000000001000000000000$ 00020110011

Megalodoras guayoensis

$000001200000000020 ? 00001000000000000 ? 10012000000000100000021$ 000000001000000000011011010011000001000100301000000001000021 $00100000000011000000000000110010000 ? 0000001000001100000 ? 0110$ $0111000000000000011000 ? 1130100101200140112101000010000101010$ $0010010000100100010000001200 ? 1001110111000000001000000000000$ 000201100??

Megalodoras uranoscopus

$000001200000000020 ? 0000100000000000 ? 10012000000000100000021$ 000000001000000000011011010011000001000100301000000001000021 $00100000000011000000000000110010000 ? 0000001000001100000 ? 0110$ $0111000000000000011000 ? 1130100101200140112101000010000101010$ $0010010000100100010000001200 ? 1001110111000000001000000000000$ $000201100 ?$ ?

Nemadoras elongatus

$000002200001000020 ? 10100 ? 00000100000 ? 0 ? 001100000000121010011$ 000000001000010000111011120011000101000000300001000000000021 100101002??111000100000100111010010?000000101100110011200111 $1111000010000100011100 ? 1131100101200130111001010010100101010$ $0010010001100100010000001220 ? 1010100111000000001000000000000$ 00020110011

Nemadoras hemipeltis

000002200001000020?10100?00000100000?0?001100000000121010001 000000001000010000111011120011000101000000300001000000000011 100101002??111000100000100111010010?000000101100110011200111 $1111000010000100011100 ? 1131100101200130111001010010100101010$ $0010010001100100010000001220 ? 1010100111000000001000000000000$ 00020110011

Nemadoras humeralis

000002200001000020?10100?00000100000?0?001100000000121010011 000000001000010000111011120011000101000000300001000000000021 100101002??111000100000100111010010?000000101100110011200111 $1111000010000100011100 ? 11311001012001301110010101 ? ? 100101010$ $0010010001100100010000001220 ? 1010100111000000001000000000000$ 00020110011

Orinocodoras eigenmanni

$110100200000000020 ? 00001000000000000 ? 10011000000000100000021$ 000000001000000000011011010011000001000000310000000002000021 $00110000000011000100000000111110000 ? 100000100000110000000110$ $3111000000000000011010 ? 1130100101200130111001000010000101010$ $0010010000100100010000001210 ? 1000110111000000001000000000000$ 01020110011

Ossancora asterophysa

000002200001100021110100?00000000000?0?001000000000120010021 000000001000010000011011120011000101000000300001000000000021 $10010100100011000100000100111010010 ? 000000101000110010100111$ $1111000010000100011100 ? 1131100101200130111001000010100101010$ $0010010000100100010000001220 ? 1111100111000020001000000000000$ 00020110011
Ossancora eigenmanni

000002200001100021110100?00000000000?0?001000000000120010021 000000001000010000011011120011000101000000300001000000000021 $10010100100011000100000100111010010 ? 000000101000110010100111$ $1111000010000100011100 ? 1131100101200130111001000010100101010$ $0010010000100100010000001220 ? 1111100111000020001000000000000$ 00020110011

Ossancora fimbriata

$000002200001100021010100 ? 00000000000 ? 0 ? 00100000000120010021$ 000000001000010000011011120011000101000000300001000000000021 $10010100100011000100000100111010010 ? 000000101000110010100111$ $1111000010000100011100 ? 1131100101200130111001010010$ A00101010 $0010010000100100010000001220 ? 1111110111000020001000000000000$ 00020110011

Ossancora punctata

$000002200001000020 ? 10100 ? 0000000000110 ? 000000000000120010021$ 000000001000010000011011120011000101000000300001000000000021 $10010100100011000100000100111010010 ? 000000101000110010100111$ $1111000010000100011100 ? 1131100101200130111001000010000101010$ $0010010000100100010000001220 ? 1111100111000020001000000000000$ 00020110011

Oxydoras kneri $000000200000000020 ? 00001000000000000 ? 11011000000000120010011$ 000001001000000000011011010011000101000000300001000001000021 $000101002 ? ? 111000100000200111010000 ? 000000100000110011210111$ ?111000010000100011100?113010010120013011??01000010000101010 $0010010001100100010000001200 ? 1010100111000000001000000000000$ 00020110011

Oxydoras niger

$000000200000000020 ? 0000100000000000 ? 11011000000000120010011$ $000001001000000000011011010011000101000000 C 00001000001000021$ 000101002??111000100000200111010000?000000100000110011210111 2111000010000100011100?113010010120013111B101000010A00101010 $0010010001100100010000001200 ? 1010100111000000001000000000000$ 00020110011

Platydoras armatulus

$110001200000000020 ? 00000 ? 00000000000 ? 11000000000000100000$ A21 000000001000000000011011010011000011000100311110000000000021 01110000000011000000000000110010000?000000100000110000000A10 $0111000000000000011000 ? 113010010120013011$ B001000010000101010 00100A000010010001000000120111000110111000000001000000000000 01020110011

Platydoras sp.

$110001200000000020 ? 00000 ? 00000000000 ? 0 ? 00000000000100000021$ 000000001000000000011011010011000001000100300010000002000021 $00110000000011000100000000110010000 ? 000000100000110000000110$ $0111000000000000011000 ? 1130100101200130111001000010000101010$ 00100A000010010001000000120111000110111000000001000000000000 01020110011

Pterodoras granulosus

000000200000000020?00001000000000000?0?312000000000110000A21 000000001000000000011011020011000001010000311000000002000021 00100000000011000A00000000110010000?000000100000110000000110 $0111000000000000011000 ? 1130100101200140112101000010000101010$ $0010010000100100010000001200 ? 1000100111000000001000000000000$ 00020110011

Pterodoras rivasi

$000000200000000020 ? 00001000000000000 ? 10012000000000110000021$ 000000001000000000011011020011000001010000311000000002000021 
$00100000000011000000000000110010000 ? 000000100000110000000110$ $0111000000000000011000 ? 1130100101200140112101000010000101010$ $0010010000100100010000001200 ? 1000100111000000001000000000000$ 00020110011

Rhinodoras boehlkei

$000100200000000120 ? 00001000000000000 ? 0 ? 011000000000100000021$ 000000001000000000011011010011000001000000300000000002000021 $00110000000011000100000000111110000 ? 100000100000110000010110$ 3111000000000000011010 ?1130100101200130111001000010000101010 $0010010000100100010000001210 ? 100011011100000000100000000000$ 01020110011

Rhinodoras dorbignyi

$000100200000000120 ? 00001000000000000 ? 10011000000000100000021$ 000000001000000000011011010011000001000000300000000002000021 00A10000000011000100000000111110000?100000100000110000010110 $3111000000000000011010 ? 1130100101200$ A30111001000010000101010 $0010010000100100010000001210 ? 100011011100000000100000000000$ 01020110011

Rhinodoras thomersoni

$000100200000000120 ? 00001000000000000 ? 1001000000000100000021$ 000000001000000000011011010011000001000000300000000002000021 $00110000000011000100000000111110000 ? 1000001000001100000 ? 0110$ $3111000000000000011010 ? 1130100101200130111001000010000101010$ $0010010000100100010000001210 ? 100011011100000000100000000000$ 01020110012

Rhynchodoras castilloi

$000000200000000020 ? 00001000000100100 ? 0 ? 200000000000100000021$ $00000000100000000001101102001100000100000030000000000 ? 000021$ $00011000000011000100000000111110000 ? 100000100000110000000110$ $0111000000000000011000 ? 11301001012000301111010001 ? ? 100101010$ $0010010000100100010000001210 ? 10000 ? 011100000000100000000000$ 01020110011

Rhynchodoras woodsi

000000200000000020?00001000000100100?0?200000000000100000021 $00000000100000000001101102001100000100000030000000000 ? 000021$ $00011000000011000100000000111110000 ? 100000100000110000000110$ $0111000000000000011000 ? 11301001012000301111010001 ? ? 100101010$ $0010010000100100010000001210 ? 10000 ? 0111000000001000000000000$ 01020110011

Scorpiodoras heckelii

000002200000000020?00000?00000000000?10000000000000100000021 010000001000000000111011020011000001010100300010000002000021 $00110000000011000000000000110010000 ? 000000100000110000000110$ $0111000000000000011000 ? 1130100101200110111001000010000101010$ 001000000010010001000000120121001100111000000001000000000000 00020100012

Tenellus leporhinus

011002200001000020?10100?00000100000?0?001000000000121010001 001000001000010000111011120011000101000000300001000000000011 100101002??111000100000100111010010?000000101100110011200111 $1111000010000100011100 ? 1131100101200130111001010010100101010$ $0010010001100100010000001220 ? 1010100111000010001000000000000$ 00020110011

Tenellus ternetzi

011002200001000020?10100?00000100000?0?001000000000121010001 001000001000010000111011120011000101000000300001000000000021 100101002??111000100000100111010010?000000101100110011200111 $1111000010000100011100 ? 11311001012001301110010101 ? ? 100101010$ $0010010001100100010000001220 ? 1010100111000010001000000000000$
00020110011

Tenellus trimaculatus

011002200001000020?10100?00000100000?0?001000000000121010001 001000001000010000111011120011000101000000300001000000000021 100101002??:111000100000100111010010?000000101100110011200111 $1111000010000100011100 ? 11311001012001301110010101 ? ? 100101010$ $0010010001100100010000001220 ? 1010100111000000001000000000000$ 00020110011

Trachydoras brevis

$000002200001000020 ? 10100 ? 0000010000110 ? 001000000000120020001$ 000000001000010000111211120011000101000001300001000000000021 100101002??:111000100000200111010010?000000101100110010100110 022????011000100011100?1131100101200130111001000010000101010 $0010010002100100010000001220 ? 1010100111000020001000000000000$ 00020110011

Trachydoras microstomus

$000002200001000020 ? 10100 ? 0000010000110 ? 001000000000120020001$ 000000001000010000111211120011000101000001300001000000000021 $100101002 ? ? 111000100000200111010010 ? 000000101100110010100110$ 022????011000100011100?1131100101200130111001000010000101010 $0010010002100100010000001220 ? 1010100111000020001000000000000$ 00020110011

Trachydoras nattereri

000002200001000020?10100?0000010000110?001000000000120020001 000000001000010000111211120011000101000001300001000000000021 100101002??111000100000200111010010?000000101100110010100110 022????011000100011100?1131100101200130111001000010000101010 $0010010002100100010000001220 ? 1010100111000020001000000000000$ 00020110011

Trachydoras paraguayensis

$000002200001000020 ? 10100 ? 0000010000110 ? 001000000000120020001$ 000000001000010000111211120011000101000001300001000000000021 $100101002 ? ? 111000100000200111010010 ? 000000101100110010100110$ 022????011000100011100?1131100101200130111001000010000101010 $0010010002100100010000001220 ? 1111100111000020001000000000000$ 00020110011

Trachydoras steindachneri

000002200001000020?10100?0000010000110?001000000000120120001 000000001000010000111211120011000101000001300011000000000021 $100101002 ? ? 111000100000200111010010 ? 000000101100110010100110$ 022????011000100011100?1131100101200130111001000010000101010 $0010010002100100010000001220 ? 1011100111000020001000000000000$ 00020110011

Wertheimeria maculata

000000200000000020?00000?00000000000?0?000000000000110000A21 000000001000000000011011010011000001000000300000000002000010 001100000000110001000000001100100021000000200000110000000110 $0111000000000000011000 ? 1130100101200110112100000010000101010$ $0010000000100100010000000200 ? 1000100011000000001000000000000$ 00020100012

\section{Literature Cited}

Acero P., A. \& R. Betancur-R. 2007. Monophyly, affinities, and subfamilial clades of sea catfishes (Siluriformes: Ariidae). Ichthyological Exploration of Freshwaters, 18: 133-143.

Akama, A. 1999. Sistemática do gênero Pseudauchenipterus Bleeker, 1862 (Siluriformes, Auchenipteridae). Unpublished M.Sc. 
Thesis, Universidade de São Paulo, São Paulo, 123p.

Akama, A. 2004. Revisão sistemática dos gêneros Parauchenipterus Bleeker, 1862 e Trachelyopterus Valenciennes, 1840 (Siluriformes, Auchenipteridae). Unpublished Ph.D. Dissertation, Universidade de São Paulo, São Paulo, 375p.

Akama, A. \& C. J. Ferraris Jr. 2003. Entomocorus melaphareus, a new species of auchenipterid catfish (Osteichthyes: Siluriformes) from the lower and middle reaches of the rio Amazonas. Neotropical Ichthyology, 1: 77-82.

Akama, A. \& C. J. Ferraris Jr. 2011. Spinipterus, a new genus of small, spiny catfish (Siluriformes: Auchenipteridae). Zootaxa, 2992: 52-60.

Alexander, R. M. 1964. The structure of the Weberian Apparatus in the Siluri. Proceedings of the Zoological Society of London, 142: 419-440.

Alexander, R. M. 1965. Structure and function in the catfish. Journal of Zoology, 148: 88-152.

Allis, E. P. 1903. The skull and cranial and first spinal muscles and nerves of Scomber scomber. Journal of Morphology, 18: 45328.

Arce H., M., R. E. Reis, A. J. Geneva \& M. H. Sabaj Pérez. 2013. Molecular phylogeny of thorny catfishes (Siluriformes: Doradidae). Molecular Phylogenetics and Evolution, 67: 560577.

Arratia, G. 1987. Description of the primitive family Diplomystidae (Siluriformes, Teleostei, Pisces): morphology, taxonomy and phylogenetic implications. Bonner Zoologische Monographien, 24: 1-120.

Arratia, G. 1992. Development and variation of the suspensorium of primitive catfishes (Teleostei: Ostariophysi) and their phylogenetic relationships. Bonner Zoologische Monographien, 32: 1-149.

Arratia, G. 2003a. Catfish head skeleton, an overview. Pp. 3-46. In: Arratia, G., B. G. Kapoor, M. Chardon \& R. Diogo (Eds.). Catfishes. Enfield, Science Publishers, Inc.

Arratia, G. 2003b. The Siluriform postcranial skeleton, an overview. Pp. 121-158. In: Arratia, G., B. G. Kapoor, M. Chardon \& R. Diogo (Eds.). Catfishes. Enfield, Science Publishers, Inc.

Arratia, G. \& L. Huaquin. 1995. Morphology of the lateral line system and of the skin of diplomystid and certain primitive loricarioid catfishes and systematic and ecological considerations. Bonner Zoologische Monographien, 36: 1-109.

Arratia, G. \& H. P. Schultze. 1990. The urohyal: development and homology within osteichthyans. Journal of Morphology, 203: 247-282.

Artedi, P. 1738. Ichthyologia, sive opera omina de piscibus scilicet: Biblioteca ichthyologica. Philosphia ichthyologica. Generum piscium. Synonymia specierum. Descriptiones specierum. Omnia in hoc opere perfectiora, quam antea ulla. Posthuma vindicavit, recognovit, coeptavit et edidit Carolus Linnaeus. 5 volumes. Leyden.

Bailey, R. M. \& J. N. Baskin. 1976. Scoloplax dicra, a new armored catfish from the Bolivian Amazon. Occasional Papers of the Museum of Zoology, 674: 1-14.

Bemis, W. F., E. J. Hilton, B. Brown, R. Arrindell, A. M. Richmond, C. D. Little, L. Grande, P. L. Forey \& G. J. Nelson. 2004. Methods for preparing dry, partially articulated skeletons of osteichthyans, with notes on making ridewood dissections of the cranial skeleton. Copeia, 2004: 603-609.

Berg, L. S. 1940. Classification of fishes, both Recent and fossil. Trudy Instituta Zoologii/Akademiia Nauk, Azerbaidzhanskoi SSR, 5: 87-517.
Birindelli, J. L. O. 2010. Relações filogenéticas da superfamília Doradoidea (Ostariophysi, Siluriformes). Unpublished Ph.D. Dissertation, Universidade de São Paulo, São Paulo, 376p.

Birindelli, J. L. O., M. H. Sabaj, D. C. Taphorn. 2007. New species of Rhynchodoras from the Río Orinoco, Venezuela, with comments on the genus (Siluriformes: Doradidae). Copeia, 2007: 672-684.

Birindelli, J. L. O., L. M. Sousa \& M. H. Sabaj Pérez. 2008. New species of thorny catfish, genus Leptodoras Boulenger (Siluriformes: Doradidae), from Tapajós and Xingu basins, Brazil. Neotropical Ichthyology, 6: 465-480.

Birindelli, J. L. O., L. M. Sousa \& M. H. Sabaj Pérez. 2009. Morphology of the gas bladder in thorny catfishes (Siluriformes: Doradidae). Proceedings of the Academy of Natural Sciences of Philadelphia, 158: 261-296.

Birindelli, J. L. O. \& L. M. Sousa. 2010. New species of thorny catfish genus Leptodoras (Siluriformes: Doradidae) from Rio Fresco, Xingu basin, Brazil. Copeia, 2010: 293-300.

Birindelli, J. L. O. \& M. H. Sabaj Pérez. 2011. Ossancora, new genus of thorny catfish (Teleostei: Siluriformes: Doradidae) with description of one new species. Proceedings of the Academy of Natural Sciences of Philadelphia, 161: 117-152.

Birindelli, J. L. O., D. F. Fayal \& W. B. Wosiacki. 2011. Taxonomic revision of thorny catfish genus Hassar (Siluriformes, Doradidae). Neotropical Ichthyology, 9: 515-542.

Birindelli, J. L. O., A. Akama \& H. A. Britski. 2012. Morphology of the gas bladder in driftwood catfishes (Siluriformes: Auchenipteridae). Journal of Morphology, 273: 651-660.

Birindelli, J. L. O. \& J. Zuanon. 2012. Systematics of the Jaguar catfish genus Liosomadoras Fowler, 1940 (Auchenipteridae: Siluriformes). Neotropical Ichthyology, 10: 1-11.

Bleeker, P. 1858. De visschen van den Indischen Archipel. Beschreven en toegelicht. Siluri. Acta Societatis Regiae Scientiarum IndoNeêrlandicae, 4: 1-370.

Bleeker, P. 1862-1863. Atlas ichthyologique des Indes Orientales Néêrlandaises, publié sous les auspices du Gouvernement colonial néêrlandais. Tome II. Siluroïdes, Chacoïdes et Hétérobranchoïdes. Amsterdam.

Bleeker, P. 1863a. Sur quelques genres nouveauz du groupe des Doras. Nederlansch Tisjdschrift voor de Dierkunde, 1: 10-18.

Bleeker, P. 1863b. Systema Silurorum revisium. Nederlansch Tisjdschrift voor de Dierkunde, 1: 77-122.

Bleeker, P. 1864. Description des espèces de Silures de Suriname, conservées aux Musées de Leide et d'Amsterdam. Natuurkundige Verhandelingen van de Hollandsche Maatschappij der Wetenschappen te Haarlem (Ser. 2), 20: 1-104.

Bloch, M. E. 1794. Naturgeschichte der Ausländischen Fische. Volume 8, Berlin, 174p.

Bloch, M. E. \& J. G. Schneider. 1801. M. E. Blochii, Systema Ichthyologiae Iconibus cx Illustratum. Post Obitum Auctoris Opus Inchoatum Absolvit, Correxit, Interpolavit Jo. Gottlob Schneider, Saxo, Sumtibus Austoris Impressum et Bibliopolio Sanderiano Commissum, Berolini.

Bockmann, F. A. \& A. M. Miquelarena. 2008. Anatomy and phylogenetic relationships of a new catfish species from northeastern Argentina with comments on the phylogenetic relationships of the genus Rhamdella Eigenmann and Eigenmann 1888 (Siluriformes, Heptapteridae). Zootaxa, 1780: $1-50$.

Boulenger, G. A. 1898. On a collection of fishes from the Rio Jurua, Brazil. Transactions of the Zoological Society of London, 14: 421-428. 
Bremer, K. 1994. Branch support and tree stability. Cladistics, 10: 295-304.

Bridge, T. W. \& A. C. Haddon. 1892. Contributions to the anatomy of fishes. II. The air-bladder and Weberian ossicles in the Siluridae. Philosophical Transactions of the Royal Society of London (series B), 84: 65-333.

Britski, H. A. 1972. Sistemática e evolução dos Auchenipteridae e Ageneiosidae (Teleostei, Siluriformes). Unpublished Ph.D. Dissertation, Universidade de São Paulo, São Paulo, 142p.

Britski, H. A. \& A. Akama. 2011. New species of Trachycorystes Bleeker, with comments on other species of the genus (Ostariophysi: Siluriformes: Auchenipteridae). Neotropical Ichthyology, 9: 273-280.

Britto, M. R. 2002. Análise filogenética da ordem Siluformes com ênfase nas relações da superfamília Loricarioidea (Teleostei: Ostariophysi). Unpublished Ph.D. Dissertation, Universidade de São Paulo, São Paulo, 512p.

Burgess, W. E. 1989. An Atlas of Freshwater and Marine Catfishes. A preliminary survey of the Siluriformes. Neptune City, T.F.H. Publications.

Burgess, W. E. \& K. Azuma. 1982. The first spawning of the woodcat, Trachycorystes insignis. Tropical Fish Hobbyist, 30: 84-89.

Burns, J. R., A. D. Meisner, S. H. Weitzman \& L. R. Malabarba. 2002. Sperm and spermatozeugma ultrastructure in the inseminating catfish, Trachelyopterus lucenai (Ostariophysi: Siluriformes: Auchenipteridae). Copeia, 2002: 173-179.

Carvalho, F. M. \& E. K. Resende. 1984. Aspectos da biologia de Tocantinsia depressa (Siluriformes, Auchenipteridae). Amazoniana, 8: 327-337.

Carvalho, L. N., R. Arruda \& J. Zuanon. 2003. Record of cleaning behavior by Platydoras costatus (Siluriformes: Doradidae) in the Amazon Basin, Brazil. Neotropical Ichthyology, 1: 137139.

Carvalho, M., F. A. Bockmann \& M. R. Carvalho. 2013. Homology of the fifth epibranchial and accessory elements of the ceratobranchials among Gnathostomes: insights from the development of Ostariophysans. Plos One, 8: 1-21.

Casteby, M. 1771. The natural history of Carolina, Florida and the Bahamas Island; containing the figures of birds, beasts, fishes, serpents...with their descriptions in English and French, etc. $3^{\text {rd. }}$ ed., 2 volumes. London.

Castelnau, F. L. 1855. Poissons. In: Animaux Nouveaux or Rares Recueillis Pendant l'Expédition dans les Parties Centrales de l'Amérique du Sud, de Rio de Janeiro à Lima, et de Lima au Para; Exécutée par Ordre du Gouvernement Français Pendant les Années 1843 a 1847, P. Bertrand, Paris.

Chardon, M. 1968. Anatomie comparée de l'appareil de Weber et structures connexes chez les Siluriformes. Annales de Musée Royale de l'Afrique Central (series in $8^{\circ}$ ), Sciences Zoologiques, 169: 1-277.

Chardon, M., E. Parmentier \& P. Vandewalle. 2003. Pp. 71-120. In: Arratia, G., B. G. Kapoor, M. Chardon \& R. Diogo (Eds.). Catfishes. Enfield, Science Publishers, Inc.

Collette, B. B. 1977. Epidermal breeding tubercles and bony contact organs in fishes. Symposium of Zoological Society of London, 39: 225-268.

Cope, E. D. 1878. Synopsis of the fishes of the Peruvian Amazon obtained by Professor Orton during his expedition of 1873 and 1877. Proceedings of the American Philosophical Society, 17: 673-701.
Curran, D. J. 1989. Phylogenetic relationships among the catfish genera of the family Auchenipteridae (Teleostei: Siluroidea). Copeia, 1989: 408-419.

Cuvier, G. 1816. Le règne animal distribué d’après son organisation, pour servir de base á l'histoire naturelle des animaux et d’introduction a l'anatomie comparée. Avec figures dessinées d'apès nature. Tome II, contenant les reptiles, les poissons, les mollusques et les annelides. Paris, Deterville.

Cuvier, G. 1829. Le Règne Animal, distribué d’après son organisation, pour servir de base à l'histoire naturelle des animaux et d'introduction à l' anatomie comparée. Tome II, $2^{\text {nd }}$ Edition. Paris, Deterville.

Cuvier, G. 1836-1849. Le règne animal distribué d'après son organization pour servir de base a l'histoire naturelle des animaux, et d'introduction a l'anatomie comparée. $3^{\text {rd }}$ ed., 23 volumes, Paris.

Cuvier, G. \& A. Valenciennes. 1840. Histoire Naturelle des Poissons. Volume 15. Paris, Strasbourg, Bertrand, Levrault.

Diogo, R. 2004. Morphological evolution, adaptations, homoplasies, constraints and evolutionary trends: Catfishes as a case study on general phylogeny and macroevolution. Enfield, Science Publisher, Inc.

Eigenmann, C. H. 1912. The freshwater fishes of British Guiana, including a study of the ecological grouping of species, and the relation of the fauna of the plateau to that of the lowlands. Memoirs of the Carnegie Museum, 5: 1-578.

Eigenmann, C. H. 1925. A review of the Doradidae, a family of South American Nematognathi or catfishes. Transactions of the American Philosophical Society, 22: 280-365.

Eigenmann, C. H. \& R. S. Eigenmann. 1888. Preliminary notes on South American Nematognathi. Proceedings of the California Academy of Sciences (Series 2), 1: 119-172.

Eigenmann, C. H. \& R. S. Eigenmann. 1889. Preliminary notes on South American Nematognathi. II. Proceedings of the California Academy of Sciences (Series 2), 2: 28-56.

Eigenmann, C. H. \& R. S. Eigenmann. 1890. A revision of the South American Nematognathi or Catfishes. Occasional Papers of California Academy of Sciences, 1: 1-508.

Eigenmann, C. H. \& R. S. Eigenmann. 1891. A catalogue of the fresh-water fishes of South America. Proceedings of the United States National Museum, 14: 1-81.

Eschmeyer, W. N. (Ed.) 2014. Catalog of Fishes. California Academy of Sciences Available from: http://research.calacademy.org/ research/ichthyology/catalog/fishcatmain.asp. (3 Feb 2012)

Fernández-Yépez, A. 1950. Un nuevo pez de la familia Doradidae. Memoria, Sociedad de Ciencias Naturales La Salle, 10, 195198.

Fernández-Yépez, A. 1968. Contribución al conocimiento de la familia Doradidae en Venezuela. Boletín do Instituto Oceanografico de la Universidad del Oriente, 7: 7-72.

Ferraris Jr., C. J. 1988. The Auchenipteridae: putative monophyly and systematics, with classification of the Neotropical Doradoid catfishes (Ostariophysi: Siluriformes). Unpublished Ph.D. Dissertation, City University of New York, New York, 229p.

Ferraris Jr., C. J. 2007. Checklist of catfishes, recent and fossil (Osteichthyes: Siluriformes), and catalogue of siluriform primary types. Zootaxa, 1418: 1-628.

Ferraris Jr., C. J. \& J. Fernandez. 1987. Trachelyopterichthys anduzei, a new species of auchenipterid catfish from the upper Río Orinoco of Venezuela with notes on T. taeniatus (Kner). Proceedings of the Biological Society of Washington, 100: 257-261. 
Ferraris Jr., C. J. \& M. C. C. de Pinna. 1999. Higher level names for catfishes (Ostariophysi: Siluriformes). Proceedings of the California Academy of Sciences, 51: 1-17.

Ferraris Jr., C. J. \& R. P. Vari. 1999. The South American catfish genus Auchenipterus Valenciennes, 1840 (Ostariophysi: Siluriformes: Auchenipteridae): monophyly and relationships, with a revisionary study. Zoological Journal of the Linnean Society, 126: 387-450.

Ferraris Jr., C. J. \& R. P. Vari. 2000. The deep-water South American catfish genus Pseudepapterus (Ostariophysi: Auchenipteridae). Ichthyological Exploration of Freshwaters, 11: 97-112.

Ferraris Jr., C. J., R. P. Vari \& S. J. Raredon. 2005. Catfishes of the genus Auchenipterichthys (Osteichthyes: Siluriformes: Auchenipteridae). Neotropical Ichthyology, 3: 89-106.

Fine, M. L. \& F. Ladich. 2003. Sound production, spine locking, and related adaptations. Pp. 249-290. In: Arratia, G., B. G. Kapoor, M. Chardon \& R. Diogo (Eds.). Catfishes. Enfield, Science Publishers, Inc.

Fowler, H. 1951. Os peixes de água doce do Brasil. Arquivos de Zoologia do Estado de São Paulo, 6: 405-625.

Franke, H-J. 1990. The first breeding of starry woodcat, Tatia galaxias. Tropical Fish Hobbyist, 1990: 20-34.

Freihofer, W. C. 1963. Patterns of the ramus lateralis accessorius and their systematic significance in teleostean fishes. Stanford Ichthyological Bulletin, 8: 80-189.

Freihofer, W. C. 1978. Cranial nerves of a percoid fish, Polycentrus schomburgkii (Family Nandidae), a contribution to the morphology and classification of the order Perciformes. Occasional Papers of the California Academy of Sciences, 128: 1-78.

Friel, J. P. 1994. A phylogenetic study of the Neotropical banjo catfishes (Teleostei: Siluriformes: Aspredinidae). Unpublished Ph.D. Dissertation, Duke University, Durham, 256p.

Goloboff, P. A., J. S. Farris \& K. C. Nixon. 2008. TNT, a free program for phylogenetic analysis. Cladistics, 24: 774-786.

Gosline, W. A. 1945. Catálogo dos nematognatos de água doce da America do Sul e Central. Boletim do Museu Nacional do Rio de Janeiro, 33: 1-138.

Goulding, M. 1979. Ecologia da pesca do rio Madeira. Manaus, INPA.

Goulding, M. 1980. The fishes and the forest, explorations in Amazonian natural history. Berkeley, University of California Press.

Grande, L. 1987. Redescription of Hypsidoris farsonensis (Teleostei: Siluriformes), with a reassessment of its phylogenetic relationships. Journal of Vertebrate Paleontology, 7: 24-54.

Grande, L. \& M. C. C. de Pinna. 1998. Description of a second species of the catfish Hypsidoris and a reevaluation of the family Hypsidoridae. Journal of Vertebrate Paleontology, 18: 451-474.

Günther, A. 1864. Catalogue of fishes in the British Museum. Catalogue of the Physostomi, containing the families Siluridae, Characinidae, Haplochitonidae, Sternoptychidae, Scopelidae, Stomiatidae in the collection of the British Museum. Volume 5, London, Taylor \& Francis.

Hardman, M. 2005. The phylogenetic relationships among nondiplomystid catfishes as inferred from mitochondrial cytochrome b sequences; the search for the ictalurid sister taxon (Otophysi: Siluriformes). Molecular Phylogenetics and Evolution, 37: 700-720.

Hennig, W. 1950. Grundzüge einer Theorie der phylogenetischen Systematik. Berlin, Deutsche Zentralverlag.
Hennig, W. 1966. Phylogenetic systematics. University of Illinois Press, Urbana.

Higuchi, H. 1992. A phylogeny of the South American thorny catfishes (Osteichthyes; Siluriformes; Doradidae). Unpublished Ph.D. Dissertation, Harvard University, Boston, 372p.

Higuchi, H., H. A. Britski \& J. C. Garavello. 1990. Kalyptodoras bahiensis, a new genus and species of thorny catfish from northeastern Brazil (Siluriformes, Doradidae). Ichthyological Exploration of Freshwaters, 1: 219-225.

Higuchi, H., J. L. O. Birindelli, L. M. Sousa \& H. A. Britski. 2007. Merodoras nheco, new genus and species of doradid from Pantanal Matogrossense, with nomination of the new subfamily Astrodoradinae (Siluriformes, Doradidae). Zootaxa, 1446: 31-42.

Ihering, R. von. 1937. Ovicucal fertilization in South American catfish, Trachycorystes. Copeia, 1937: 201-205.

Jardine, W. 1841. The naturalist’s library (Volume 32). Ichthyology. Volume III. Fishes of Guiana. Part I. Edinburgh.

Jordan, D. S. 1917. The genera of fishes from Linnaeus to Cuvier, 1758-1833, seventy-five years, with the accepted type of each. A contribution to the stability of Scientific Nomenclature. Palo Alto, Stanford University.

Jordan, D. S. 1929. Manual of the vertebrate animals of the northeastern United States inclusive of marine species. $13^{\circ}$ edition. New York, World Book Co.

Kesteven, H. L. 1943. The evolution of the skull and cephalic muscles. I. The fishes. Memoir of the Australian Museum, 8: 65-132.

Kner, R. 1854. Ueber einige Sexual-Unterschiede bei der Gattung Callichthys und die Schwimmblase dei Doras C. Val. Sitzungsber. Akademie der Wissenschaften in Wien, 11: 138-146.

Kner, R. 1855. Ichthyologische Beiträge [Subtitles I-III]. Sittzungsber. Akademie der Wissenschaften in Wien, 17: 92162.

Kner, R. 1858. Kritische Bemerkungen über Castelnau’s Siluroiden. Archiv fur Naturgeschichte, 24, 344-350.

Kulongowski, C. 2001. The anatomy and taxonomy of the marine catfish genus Galeichthys Valenciennes (Siluriformes; Ariidae). Unpublished MSc. Dissertation, Rhodes University, Grahamstown, 150p.

Lacepède, B. G. E. 1803. Histoire naturelle des poisons. Volume 5, Plasson, Paris.

Ladich, F. 2001. Sound-generating and -detecting motor system in catfish: design of swimbladder muscles in doradids and pimelodids. The Anatomical Records, 263: 297-306.

Lechner, W \& F. Ladich. 2008. Size matters: diversity in swimbladders and Weberian ossicles affects hearing in catfishes. The Journal of Experimental Biology, 211: 1681-1689.

Linnaeus, C. 1758 . Systema Naturae. $10^{\circ}$ edition, volume 1, Laurentii Salvii, Holmiae.

Linnaeus, C. 1766 . Systema Naturae. $12^{\circ}$ edition, volume 1 , Laurentii Salvii, Holmiae.

Loir, M., C. Cauty, P. Planquete \& P. Y. le Bail. 1989. Comparative study of the male reproductive tract in seven families of South American catfishes. Aquatic Living Resources, 2: 45-56.

Lundberg, J. G. 1970. The evolutionary history of North American catfishes, family Ictaluridae. Unpublished Ph.D. Dissertation, University of Michigan, Ann Arbor, 524p.

Lundberg, J. G. 1993. African-South American freshwater fish clades and continental drift: problems with a paradigm. Pp. 156-199. In: Goldblatt, P. (Ed.). Biological relationships between Africa and South America. New Haven, Yale University Press. 
Lundberg, J. G. \& A. Akama. 2005. Brachyplatystoma capapretum, a new species of goliath catfish from the Amazon basin, with reclassification of allied catfishes (Siluriformes; Pimelodidae). Copeia, 2005: 492-516.

Lundberg, J. G. \& J. N. Baskin. 1969. The caudal skeleton of the catfishes, order Siluriformes. American Museum Novitates, 2398: 1-49.

Lundberg, J. G., K. R. Luckenbill, K. K. Subhash Babu \& H. H. Ng. 2014. A tomography osteology of the taxonomically puzzling catfish Kryptoglanis shajii (Siluriformes, Siluroidei, incertae sedis): description and a first phylogenetic interpretation. Proceedings of the Academy of Natural Sciences of Philadelphia, 163: 1-41.

Lütken, C. F. 1874. Siluridæ novæ Brasiliæ centralis a clarissimo J. Reinhardt in provincia Minae-geraës circa oppidulum Lagoa Santa, præcipue in flumine Rio das Velhas et affluentibus collectæ, secundum characteres essentiales breviter descriptæ a Chr. Lütken. Oversigt over det Kongelige Danske Videnskabernes Selskabs Forhandlinger og dets Medlemmers Arbejder i Aaret, 1874: 29-36.

McAllister, D. E. 1968. The evolution of branchiostegals and associated opercular, gular, and hyoid bones and the classification of teleostome fishes, living and fossil. Bulletin of the National Museum of Canada, 221: 1-239.

Madison, D. R. \& W. P. Madison. 2005. MacClade 4, release version 4.08 (for OS X). Sinauer Associates, Inc.

Marceniuk, A. F. \& J. L. O. Birindelli. 2010. Morphology of the gas bladder in sea catfishes (Siluriformes: Ariidae). Zootaxa, 2579: 59-68.

Marceniuk, A. F., N. A. Menezes \& M. R. Britto. 2012. Phylogenetic analysis of the family Ariidae (Ostariophysi: Siluriformes), with a hypothesis on the monophyly and relationships of the genera. Zoological Journal of the Linnean Society, 165: 534-669.

Mazzoldi, C., V. Lorenzi \& M. B. Rasotto. 2007. Variation of male reproductive apparatus in relation to fertilization modalities in the catfish families Auchenipteridae and Callichthyidae (Teleostei: Siluriformes). Journal of Fish Biology, 70: 243-256.

Mees, G. F. 1974. The Auchenipteridae and Pimelodidae of Suriname (Pisces, Nematognathi). Zoologische Verhandelingen, 132: 1-256.

Meisner, A. D., J. R. Burns, S. H. Weitzman \& L. R. Malabarba. 2009. Morphology and histology of the male reproductive system in two species of internally inseminating South American catfishes, Trachelyopterus lucenai and T. galeatus (Teleostei: Auchenipteridae). Journal of Morphology, 246: 131-141.

Miranda Ribeiro, A. 1911. Fauna brasiliensis. Peixes IV(a). Eleutherobranchios Aspirophoros. Archivos do Museu Nacional do Rio de Janeiro, 16: 1-504.

Miranda Ribeiro, A. 1918. Lista dos Peixes Brasileiros do Museu Paulista (part 1). Revista do Museu Paulista, 10: 706-736.

Miranda Ribeiro, P. 1968a. Sobre o dimorfismo sexual no gênero Auchenipterus Valenciennes, 1840 (Pisces-Auchenipteridae). Boletim do Museu Nacional do Rio de Janeiro, Nova Série, Zoologia, 261: 1-11.

Miranda Ribeiro, P. 1968b. Apontamentos ictiológicos III. Boletim do Museu Nacional do Rio de Janeiro, Nova Série, Zoologia, 263: 1-14.

Miranda Ribeiro, P. 1968c. Apontamentos ictiológicos V. Boletim do Museu Nacional do Rio de Janeiro, Nova Série, Zoologia, 264: $1-5$.

Mo, T.-P. 1991. Anatomy, relationships and systematics of the Bagridae (Teleostei: Siluroidei) and siluroid phylogeny. Theses Zoologicae, 17: 1-216.
Moyer, G., B. M. Burr \& C. Krajewski. 2004. Phylogenetic relationships of thorny catfishes (Siluriformes: Doradidae) inferred from molecular and morphological data. Zoological Journal of the Linnean Society, 140: 551-575.

Müller, J. 1842a. Über die Schwimmblase der Fische, mit Bezug auf eínige neue Fishgattungen. Königlichen Preussische Akademie des Wissenschaften zu Berlin, 1842: 202-210.

Müller, J. 1842b. Beobachtungen über die Schwimmblase der Fische, mit Bezug auf einige neue Fischgattungen. Archiv für Anatomie, Physiologie und wissenschaftliche Medicin (Müller), Jahr, 1842: 307-329.

Müller, H. 1843. Untersuchungen über die Eingeweide der Fische, Schulufs der vergleichenden Anatomie der Myxinoiden. Abhanglungen der Königlichen Akademie der Wissenschaften, 1843: 111-170.

Nelson, J. S. 2006. Fishes of the world. $4^{\text {th }}$ ed. New York, John Wiley \& Sons, Inc.

Nixon, K. C. 1999-2002. WinClada ver. 1.0000. Ithaca, NY, USA. Available from http://www.cladistics.com/index.html.

Parmentier, E. \& R. Diogo. 2006. Evolutionary trends of swimbladder sound mechanism in some teleost fishes. Pp. 4368. In: Ladich, F., S. P. Collin, P. Moller \& B. G. Kapoor (Eds.). Communication in Fishes. Enfield, Science Publisher, Inc.

Pavanelli, C. S. \& A. G. Bifi. 2009. A new Tatia (Ostariophysi: Siluriformes: Auchenipteridae) from the rio Iguaçu basin, Paraná State, Brazil. Neotropical Ichthyology, 7: 199-204.

Parreira, G. G., H. Chiarini-Garcia, R. C. N. Mello, F. O. Vieira \& H. P. Godinho. 2009. Spermatozoon and its relationships with the ovarian lamellae in the internally inseminating catfish Trachelyopterus galeatus. Microscopy Research and Technique, 72: 889-897.

Peixoto, L. A. W. \& W. B. Wosiacki. 2010. Description of a new species of Tetranematichthys (Siluriformes: Auchenipteridae) from the lower Amazon basin, Brazil. Neotropical Ichthyology, 8: 69-76.

de Pinna, M. C. C. 1991. Concepts and tests of homology in the cladistic paradigm. Cladistics, 7: 367-394.

de Pinna, M. C. C. 1993. Higher-level phylogeny of Siluriformes (Teleostei, Ostariophysi), with a new classification of the order. Unpublished Ph.D. Dissertation, City University of New York, New York, 474p.

de Pinna, M. C. C. 1996. A phylogenetic analysis of the Asian catfish families Sisoridae, Akysidae, and Amblycipitidae, with a hypothesis on the relationships of Neotropical Aspredinidae (Teleostei, Ostariophysi). Fieldiana, 1478: 1-83.

de Pinna, M. C. C. 1998. Phylogenetic relationships of Neotropical Siluriformes (Teleostei: Ostariophysi): historical overview and synthesis of hypotheses. Pp. 279-330. In: Malabarba, L., R. E. Reis, R. P. Vari, Z. M. S. Lucena \& C. A. S. Lucena (Eds.). Phylogeny and Classification of Neotropical Fishes. Porto Alegre, Edipucrs.

de Pinna, M. C. C. \& Ng, H. H. 2004. The second ural centrum in Siluriformes and its implication for the monophyly of superfamily Sisoroidea (Teleostei, Ostariophysi). American Museum Novitates, 3437: 1-23.

de Pinna, M. C. C., C. J. Ferraris Jr. \& R. P. Vari. 2007. A phylogenetic study of the Neotropical catfish family Cetopsidae (Osteichthyes, Ostariophysi, Siluriformes), with a new classification. Zoological Journal of the Linnean Society, 150: 755-813.

Piorski, N. M., J. C. Garavello, M. Arce H. \& M. H. Sabaj Pérez. 2008. Platydoras brachylecis, a new species of thorny catfish 
(Siluriformes: Doradidae) from northeastern Brazil. Neotropical Ichthyology, 6: 481-493.

Poll, M. 1971. Révision des Synodontis Africains (Famille Mochocidae). Annales du Musée Royal de l'Afrique Centrale, series in $8^{\circ}$, Sciences Zoologiques, 191: 1-497.

Quagio-Grassioto, I., R. J. Ortiz, M. H. Sabaj Pérez \& C. Oliveira. 2011. Sperm of Doradidae (Teleostei: Siluriformes). Tissue and Cell, 43: 8-23.

Rafinesque, C. S. 1815. Analyse de la Nature, ou Tableau de l’Univers et des Corps Organisés, Palerme.

Regan, C. T. 1911. The classification of the teleostean fishes of the order Ostariophysi. 2. Siluroidea. Annals and Magazine of Natural History, 8: 553-577.

Reis, R. E. \& T. A. K. Borges. 2006. The South American catfish genus Entomocorus (Ostariophysi: Siluriformes: Auchenipteridae), with the description of a new species from the Paraguay River basin. Copeia, 2006: 412-422.

Rengifo, B., N. K. Lujan, D. Taphorn \& P. Petry. 2008. A new species of Gelanoglanis (Siluriformes: Auchenipteridae) from the Marañon River (Amazon Basin), northeastern Peru. Proceedings of the Academy of Natural Sciences of Philadelphia, 157: 181-188.

Ribeiro, A. C. 2006. Tectonic history and the biogeography of the freshwater fishes from the coastal drainages of eastern Brazil: an example of faunal evolution associated with a divergent continental margin. Neotropical Ichthyology, 4: 225-246.

Ribeiro, F. R. V. 2011. Sistemática do gênero Ageneiosus La Cépède (Siluriformes, Auchenipteridae). Unpublished Ph.D. Dissertation, Instituto Nacional de Pesquisas da Amazônia, Manaus, 355p.

Ribeiro, F. R. V. \& L. H. Rapp Py-Daniel. 2010. Ageneiosus uranophthalmus, a new species of auchenipterid catfish (Osteichthyes: Siluriformes) from river channels of the central Amazon basin, Brazil. Neotropical Ichthyology, 8: 97-104.

Roberts, T. R. 1982. Unculi (horny projections arising from single cells), an adaptative feature of the epidermis of ostariophysan fishes. Zoologica Scripta, 11: 55-76.

Royero, R. 1987. Morfologia de la aleta dorsal en los bagres (Teleostei: Siluriformes), con especial referencia a las familias Americanas. Unpublished undergraduate Dissertation, Universidad Central de Venezuela, Caracas, 285p.

Royero, R. 1999. Studies on the systematics and phylogeny of the catfish family Auchenipteridae (Teleostei: Siluriformes). Unpublished Ph.D. Dissertation, University of Bristol, London, 534p.

Sabaj, M. H. 2002. Taxonomy of the neotropical thorny catfishes (Siluriformes: Doradidae) and revision of the genus Leptodoras. Unpublished Ph.D. Dissertation, University of Illinois, UrbanaChampaign, 242p.

Sabaj, M. H. 2005. Taxonomy assessment of Leptodoras (Siluriformes: Doradidae) with description of three new species. Neotropical Ichthyology, 3: 637-678.

Sabaj, M. H. \& D. C. Taphorn \& O. E. Castillo G. 2008. Two new species of thicklip thornycats, genus Rhinodoras (Teleostei: Siluriformes: Doradidae). Copeia, 2008: 209-226.

Sabaj Pérez, M. H., O. A. Aguilera S. \& J. G. Lundberg. 2007. Fossil catfishes of the families Doradidae and Pimelodidae (Teleostei: Siluriformes) from the Miocene Urumaco Formation of Venezuela. Proceedings of the Academy of Natural Sciences of Philadelphia, 156: 157-194.

Sabaj Pérez, M. H. \& J. L. O. Birindelli. 2008. Taxonomic revision of extant Doras Lacepède, 1803 (Siluriformes: Doradidae) with descriptions of three new species. Proceedings of the Academy of Natural Sciences of Philadelphia, 157: 189-233.

Sabaj-Pérez, M. H. \& J. L. O. Birindelli. 2013. Hassar shewellkeimi, a new species of thorny catfish (Siluriformes: Doradidae) from the upper Tapajós basin, Brazil. Proceedings of the Academy of Natural Sciences of Philadelphia, 162: 133-156.

Sabaj, M. H. \& C. J. Ferraris. 2003. Family Doradidae. Pp. 456469. In: R. E. Reis, S. O. Kullander \& C. J. Ferraris Jr. (Eds.). Check list of the freshwater fishes of South and Central America. Porto Alegre, Edipucrs.

Sarmento-Soares, L. M., F. G. Cabeceira, L. N. Carvalho, J. Zuanon \& A. Akama. 2013. Centromochlus meridionalis, a new catfish species from the southern Amazonian limits, Mato Grosso State, Brazil (Siluriformes: Auchenipteridae). Neotropical Ichthyology, 11: 797-808.

Sarmento-Soares, L. M. \& P. A. Buckup. 2005. A new Glanidium from the Rio São Francisco basin, Brazil (Siluriformes: Auchenipteridae: Centromochlinae). Copeia, 2005: 846-853.

Sarmento-Soares, L. M. \& R. F. Martins-Pinheiro. 2008. A systematic review of the genus Tatia (Siluriformes: Auchenipteridae: Centromochlinae). Neotropical Ichthyology, 6: 495-542.

Sarmento-Soares, L. M. \& R. F. Martins-Pinheiro. 2013. Glanidium botocudo, a new species from the rio Doce and rio Mucuri, Minas Gerais, Brazil (Siluriformes: Auchenipteridae) with comments on taxonomic position of Glanidium bockmanni Sarmento-Soares \& Buckup. Neotropical Ichthyology, 11: 265274.

Sarmento-Soraes, L. M. \& M. Porto. 2006. Comparative anatomy of the cheek muscles within the Centromochlinae subfamily (Ostariophysi, Siluriformes, Auchenipteridae). Journal of Morphology, 267: 187-197.

Schaefer, S. A. 1990. Anatomy and relationships of the scoloplacid catfishes. Proceedings of the Academy of Natural Sciences of Philadelphia, 142: 167-210.

Shelden, F. F. 1937. Osteology, myology and probable evolution of the Nematognathi pelvic girdle. Annals of the New York Academy of Sciences, 37: 1-96.

Spix, J. B. von \& L. Agassiz. 1829-1831. Selecta Genera et Species Piscium quos in Itinere per Brasiliam Annos MDCCCXVIIMDCCCXX Jussu et Auspiciis Maximiliani Josephi I. Colleget et Pingendso Curavit Dr J. B. de Spix, Typis C. Wolf, Monachii.

Soares-Porto, L. M. 1996. Análise filogenética dos Centromochlidae. Redefinição e resisão taxonômica de Tatia Mirada Ribeiro, 1911 (Osteichthyes, Siluriformes, Doradoidea). Unpublished Ph.D. Dissertation, Universidade de São Paulo, São Paulo, 278p.

Soares-Porto, L. M. 1998. Monophyly and interrelationships of the Centromochlinae (Siluriformes: Auchenipteridae). Pp. 331350. In: Malabarba, L. R., R. E. Reis, R. P. Vari, Z. M. S. Lucena \& C. A. S. Lucena (Eds.). Phylogeny and Classification of Neotropical Fishes. Porto Alegre, Edipucrs.

Soares-Porto, L. M. 2000. A new species of Centromochlus (Siluriformes: Auchenipteridae) from the rio Negro drainage, Amazon basin, Brazil, with comments on its relationships. Ichthyological Exploration of Freshwaters, 11: 279-287.

Soares-Porto, L. M., S. J. Walsh, L. G. Nico \& J. M. Netto. 1999. A new species of Gelanoglanis from the Orinoco and Amazon river basin, with comments on miniaturization within the genus (Siluriformes: Auchenipteridae: Centromochlinae). Ichthyological Exploration of Freshwaters, 10: 63-72.

Sörensen, W. 1894-1895. Are the extrinsic muscles of the air-bladder in some Siluroidae and the "elastic spring" apparatus of others 
subordinate to the voluntary production of sounds? What is, according to our present knowledge, the function of the Weberian ossicles? A contribution to the biology of fishes. Journal of anatomy and Physiology, 29(1-4): 109-139 [Oct 1894], 205229 [Jan 1895], 399-423 [Apr 1895], 518-552 [Jul 1895].

Sousa, L. M. 2010. Revisão taxonômica e filogenia de Astrodoradinae (Siluriformes, Doradidae). Unpublished Ph.D. Dissertation, Universidade de São Paulo, São Paulo, 276p.

Sousa, L. M. \& J. L O. Birindelli. 2011. Taxonomic revision of the genus Scorpiodoras (Siluriformes: Doradidae) with resurrection of Scorpiodoras calderonensis and description of a new species. Copeia, 2011: 121-140.

Sousa, L. \& L. H. Rapp Py-Daniel. 2005. Description of two new species of Physopyxis and redescription of $P$. lyra (Siluriformes: Doradidae). Neotropical Ichthyology, 3: 625-636.

Steindachner, F. 1877. Die Süsswasserfische des südöstlichen Brasilien (III). Sitzungsberichte der Kaiserlichen Akademie der Wissenschaften. Mathematisch-Naturwissenschaftliche Class, 74: 559-694.

Steindachner, F. 1880. Beitäge zur Kenntniss der Flussfische Su damerikas, II, und Ichthyologische Beiträge, IX. Anzeiger der Kaiserlichen Akademie der Wissenschaften, MathematischNaturwissenschaftlichen Classe, 17: 157-159.

Steindachner, F. 1910. Über einige Ageneiosus- und FarlowellaArten, etc. Annalen des K. K. Naturhistorischen Hofmuseums, Wien, 24: 399-408.

Steindachner, F. 1915. Breiträge zur Kenntnis der Flussfische Su damerikas. V. Denkschriften der kaiserlichen Akademie der Wissenschaften, mathematisch-naturwissenschaftliche Klasse, 93: 15-106.

Stewart, D. J. 1986. Revision of Pimelodina and description of a new genus from the Peruvian Amazon (Pisces: Pimelodidae). Copeia, 1986: 653-672.

Sullivan, J. P., J. G. Lundberg \& M. Hardman. 2006. A phylogenetic analysis of the major groups of catfishes (Teleostei: Siluriformes) using rag1 and rag2 nuclear gene sequences. Molecular Phylogenetics and Evolution, 41: 636-662.

Sullivan, J. P., Z. Peng, J. G. Lundberg, J. Peng \& S. He. 2008. Molecular evidence for diphyly of the Asian catfish family Amblycipitidae (Teleostei: Siluriformes) and exclusion of the South American Aspredinidae from Sisoroidea. Proceedings of the Academy of Natural Sciences of Philadelphia, 157: 51-65.

Taverne, L. \& A. Aloulou-Triki. 1974. Étude anatomique, myologique et ostéologique du genre Synodontis Cuvier (Pisces: Siluriformes: Mochokidae). Annalen du Musée Royal de l'Afrique Centrale, 210: 1-69.

Tavolga, W. N. 1962. Mechanisms of sound production in the ariid catfishes Galeichthys and Bagre. Bulletin of the American Museum of Natural History, 124: 1-30.

Taylor, W. R. \& G. C. Van Dyke. 1985. Revised procedures for staining and clearing small fishes and other vertebrates for bone and cartilage study. Cybium, 9: 107-119.

Tilak, R. 1963. The osteocranium and the Weberian apparatus of a few representatives of the family Siluridae and Plotosidae (Siluroidea): a study of inter-relationship. Zoologische Anzeiger, 171: 424-439.

Van der Stigchel, J. W. R. 1947. The South American Nematognathi of the museums at Leiden and Amsterdam. Zoologische Mededelingen, 27: 1-204.

Vari, R. P. \& C. J. Ferraris Jr. 1998. The Neotropical catfish genus Epapterus Cope (Siluriformes: Auchenipteridae): a reappraisal. Proceedings of the Biological Society of Washington, 111: 9921007.
Vari, R. P. \& C. J. Ferraris Jr. 2006. The catfish genus Tetranematichthys (Auchenipteridae). Copeia, 2006: 168-180.

Vari, R. P. \& C. J. Ferraris Jr. 2013. Two new species of the catfish genus Tatia (Siluriformes: Auchenipteridae) from the Guiana Shield and a reevaluation of the limits of the genus. Copeia, 2013: 396-402.

Vigliotta, T. R. 2008. A phylogenetic study of the African catfish family Mochokidae (Osteichthyes, Ostariophysi, Siluriformes), with a key to genera. Proceedings of the Academy of Natural Sciences of Philadelphia, 157: 73-136.

Vono, V. \& J. L. O. Birindelli. 2007. Natural history of Wertheimeria maculata, a primitive doradid endemic to eastern Brazil (Siluriformes, Doradidae). Ichthyological Exploration of Freshwaters, 18: 183-191.

Walsh, S. J. 1990. A systematic revision of the Neotropical catfish family Ageneiosidae (Teleostei: Ostariophysi: Siluriformes). Unpublished Ph.D. Dissertation, University of Florida, Florida, 363p.

Weitzman, S. H. 1962. The osteology of Brycon meeki, a generalized characid fish, with an osteological definition of the family. Stanford Ichthyological Bulletin, 8: 1-77.

Wiley, B. B. \& M. L. Collette. 1970. Breeding tubercles and contact organs in fishes: their occurrence, structure, and significance. Bulletin of the American Museum of Natural History, 143: 145-216.

Winterbottom, R. 1974. A descriptive synonym of the striated muscles of the Teleostei. Proceedings of the Academy of Natural Sciences of Philadelphia, 125: 225-317.

Appendix. List of character state changes (i.e., synapomorphies, homoplasies, autapomorphies) of the consensus cladogram. Asterisks indicate exclusive characters (i.e., synapomorphies and autapomorphies). Number of nodes according to Figs. 67-70.

\section{Outgroup terminal taxa.}

Amphiliidae: \#23: 0>1, \#58: 1>0, \#85: 0>2, \#88: 0>1, \#89: 0>1, \#113: 3>0, \#162: 1>2, \#171: 0>1, \#175: 0>1, \#176: 0>1, \#220: 0>1, \#253: 0>1, \#273: 0>1, \#282: 0>1, \#305: 2>3, \#308: 0>1, \#310: $1>2$.

Ariidae (Galeichthys): \#80: 1>0; \#197: 0>1, \#245: 1>0, \#306: $1>0$.

Ariidae (Genidens): \#5: 0>2, \#58: 0>1, \#74: 1>0, \#85: 1>2, \#142: 0>1, \#205: 0>1, \#207: 0>1, \#216: 0>1, \#217: 1>3, \#305: $1>2$.

Aspredinidae: \#4: 0>1, \#56: 0>1, \#58: 2>0, \#89: 1>0; \#128: 0>2, \#160: 0>1, \#164: 0>1, \#181: 1>2, \#182: 1>2, \#235: 0>1, \#250: 0>1, \#272: 0>1, \#287: 1>0, \#303: 2>1, \#305: 1>3, \#306: 1>0.

Claroteidae: \#20: 1>0; \#22: 0>1, \#40: 1>0;\#102: 3>2, \#114: 1>0; \#154: 0>1,\#164: 0>1, \#221: 2>1, \#222: 2>1; \#303: 2>1, \#309: $1>2$.

Erethistidae: \#162: 1>2, \#171: 1>0, \#245: 0>1, \#273: 0>1, \#278: $0>1$.

Heptapteridae: \#59: 1>0, \#102: 3>2, \#164: 0>1, \#285: 0>1.

Ictaluridae: \#51: 1>0, \#102: $1>0$.

Malapteruridae: \#6: 0>2, \#37: 0>1, \#51: 1>0,\#58: 1>2, \#60: 1>0, \#69: 0>1, \#73: 0>1, \#113: 2>3, \#136: 0>1, \#142: 0>1, \#145: 0>1, \#205: 0>2, \#207: 0>1, \#222: 2>1, \#251: 0>1, \#265: 1>0, \#278: 1>0, \#300: 0>2.

Mochokidae (Mochokiella): \#66: 0>1,\#158: 0>1, \#245: 0>1.

Mochokidae (Mochokus): \#56: 0>1, \#58: 2>1, \#162: 0>1, \#221: 1>0, \#242: 0>1, \#254: 1>0, \#305: $2>3$.

Mochokidae (Chiloglanis): \#17: 1>0, \#23: 0>1, \#102: 3>2, \#111: 
0>1, \#152: 0>1, \#171: 0>1, \#211: 1>2, \#216: 0>1, \#228: 0>1, \#231: 0>1, \#237: 0>1, \#253: 0>1, \#254: 1>2, \#257: 1>0, \#259: 0>1, \#265: 2>1, \#282: 0>1.

Mochokidae (Synodontis): \#66: 0>1, \#107: 0>1, \#158: 0>1, \#177: 0>1, \#222: 0>1, \#224: 0>1, \#245: 0>1, \#274: 0>1, \#278: 1>0.

Nematogenyidae: \#4: 0>1, \#60: 1>0, \#88: 0>1, \#89: 0>1, \#138: 0>1, \#177: 1>2, \#192: 0>1, \#227: 0>1, \#235: 0>1, \#251: 0>1, \#265: 1>0, \#305: 1>2, \#306: $1>0$.

Pangasiidae: \#16: 2>1, \#37: 0>1, \#59: 1>0, \#75: 0>1, \#85: 0>1, \#114: 0>1, \#166: 0>1, \#167: 1>0,\#197: 1>0, \#198: 1>0,\#205: 0>2, \#207: 0>1, \#222: 2>1, \#245: 0>1, \#254: 0>1.

Pimelodidae: \#217: 1>2, \#309: $1>0$.

Pseudopimelodidae: \#59: 1>0, \#113: 2>3, \#154: 0>1, \#166: 0>1, \#242: 0>1, \#245: 0>1, \#287: 1>0, \#305: 1>2.

Siluridae: \#4: 0>1,\#22: 1>0,\#88: 0>1, \#102: 1>2, \#113: 2>3, \#131: 0>1, \#138: 0>1, \#154: 1>0, \#157: 1>0, \#168: 1>0, \#181: 1>0, \#182: 1>0, \#185: 0>1, \#186: 0>1, \#221: 2>1, \#227: 0>1, \#235: 0>1, \#257: 1>0, \#265: 1>0, \#269: $1>0$.

Sisoridae: \#85: 0>1, \#88: 1>0, \#102: 3>1, \#126: 0>1, \#131: 0>1, \#166: 0>1, \#190: 0>1, \#191: 1>0,\#192: 1>0, \#216: 1>0, \#221: 2>1, \#277: 1>0, \#308: $1>0$.

Ingroup terminal taxa (Auchenipteridae).

Ageneiosus atronasus: \#57: 1>0, \#177: 2>1, \#209: 0>1, \#287: 3>2, \#300: $1>0$.

Ageneiosus inermis: \#33: 0>1, \#34: 0>1*, \#206: 0>2*, \#222: 1>2, \#243: 0>1*, \#248: 1>2, \#263: 0>1*.

Asterophysus batrachus: \#41: 0>1, \#42: 0>1, \#44: 1>0, \#45: 0>1, \#71: 0>1*,\#113: 2>3, \#116: 0>1, \#139: 0>1, \#159: 1>0,\#162: 1>2, \#187: 0>1*, \#190: 1>0, \#199: 0>2*, \#221: 1>2, \#249: 0>2, \#276: 1>3, \#308: 0>1.

Auchenipterichthys thoracatus: \#37: 0>1, \#237: 1>0, \#239: 1>0, \#270: 0>1, \#272: 0>1.

Auchenipterus nuchalis: \#44: 1>2, \#57: 0>2, \#78: 0>1, \#237: 1>0, \#295: 0>1*.

Centromochlus heckelii: \#35: 0>1, \#59: 1>0, \#78: 0>1, \#98: 0>1, \#115: 0>1, \#163: 0>1, \#164: 0>1, \#206: 0>1, \#209: 0>1, \#217: 3>4, \#238: 1>2*, \#245: 0>1, \#258: 0>1, \#261: 0>1*, \#265: 1>2, \#272: 0>1, \#290: 1>0, \#293: 0>1*.

Entomocorus radiosus: \#27: 0>1*,\#70: 0>1*, \#87: 1>0, \#92: 1>0, \#249: 0>2, \#252: 0>1*, \#257: 0>1, \#276: 1>0, \#279: 0>1*, \#283: 1>0, \#287: 3>2, \#308: 0>1.

Epapterus dispilurus: \#4: 0>1, \#49: 0>1*, \#76: 1>0, \#237: 1>3*, \#239: 0>1.

Gelanoglanis cf. stroudi: \#16: 2>1, \#52: 1>0, \#72: 0>1*, \#112: 0>1*,\#117: 1>0,\#159: 1>0,\#181: 1>2,\#182: 1>2, \#211: 0>1, \#217: 3>1, \#222: 1>0, \#228: 0>1, \#231: 0>1, \#242: 1>0, \#257: 1>0, \#283: 0>1.

Glanidium melanopterum: \#63: 0>1, \#191: 1>0,\#221: 1>2, \#242, 1>0, \#287: $0>1$.

Liosomadoras oncinus: \#54: 0>1, \#57: 0>1, \#85: 2>1, \#106: 0>1, \#167: 1>0, \#239: 0>1, \#241: 0>1, \#267: 0>1.

Pseudauchenipterus affinis: \#20: 0>1, \#29: 0>1*, \#242: 1>0, \#257: 1>0, \#276: 1>2, \#287: $1>2$.

Pseudepapterus cucuhyensis: \#67: 0>1*, \#69: 1>0,\#127: 1>0, \#186: 2>1, \#216: 0>1, \#217: 3>2, \#248: 1>2, \#269: $1>2$.

Pseudotatia parva: \#216: 1>0, \#245: 1>0.

Tatia aulopygia: \#94: 0>1,\#131: 1>0,\#162: 1>2, \#294: 0>1*, \#298: $0>1 *$.

Tetranematichthys quadrifilis: \#37: 0>1, \#184: 0>1, \#248: 1>3, \#262: 0>1, \#306: 1>2, \#307: 0>1.

Tocantinsia piresi: \#39: 0>1, \#57: 0>1,\#170: 0>1, \#184: 0>1, \#217:
3>4, \#221: 1>2, \#242: 1>0, \#258: 0>1.

Trachelyichthys decaradiatus: \#4: 0>1, \#56: 0>1, \#237: 1>2, \#287: 2>3, \#306: 1>2.

Trachelyopterichthys taeniatus: \#4: 0>1, \#222: 1>2, \#237: 1>2, \#260: 0>1, \#287: 2>3.

Trachelyopterus coriaceus: \#4: 0>1, \#20: 0>1, \#35: 1>0, \#87: 0>1, \#94: 1>0, \#257: 1>0, \#272: 0>1.

Trachelyopterus galeatus: \#134: 0>1, \#265: 2>1

Trachycorystes trachycorystes: \#39: 0>1, \#85: 2>1, \#103: 0>1, \#239: 1>0, \#245: 1>0, \#300: 1>0, \#307: $1>0$.

\section{Ingroup terminal taxa (Doradidae).}

Acanthodoras cataphractus: \#177: 1>0, \#237: 0>1, \#274: 0>1, \#283: 0>1, \#300: 0>2, \#309: 1>2.

Agamyxis albomaculatus: \#39: 0>1, \#268: 2>0, \#280: 0>1*,\#296: 0>1*, \#297: 0>1*, \#301: 0>1, \#305: 1>2.

Anadoras grypus: \#1: 0>1, \#57: 0>1, \#102: 3>2, \#186: 0>1, \#242: $1>0$.

Anduzedoras oxyrhynchus: \#123: 1>2, \#202:0>1*.

Astrodoras asterifrons: \#61: 1>0, \#99: 1>0, \#270: 0>1, \#300: 0>1.

Centrochir crocodili: no autapomorphies.

Centrodoras brachiatus: no autapomorphies.

Centrodoras hasemani: no autapomorphies.

Doraops zuloagai: \#23: 1>0, \#104: 1>0, \#118: 2>1.

Doras carinatus: no autapomorphies.

Doras higuchii: no autapomorphies.

Doras phlyzakion: \#39: 0>1.

Franciscodoras marmoratus: \#301: 0>1.

Hassar affinis: no autapomorphies.

Hassar gabiru: no autapomorphies.

Hassar orestis: no autapomorphies.

Hemidoras morei: \#32: 1>0.

Hemidoras morrisi: \#274: 0>1.

Hemidoras stenopeltis: \#128: 2>1.

Hemidoras stubelii: no autapomorphies.

Kalyptodoras bahiensis: \#94: 0>1, \#103: 0>1, \#104: 0>1, \#105: $0>1$.

Leptodoras juruensis: \#1: 1>0,\#2: 1>0, \#9: 0>1*, \#23: 0>1, \#30: 1>0, \#78: 1>0,\#123: 1>2, \#181: 1>2, \#211: 0>1, \#221: 1>0, \#222: 1>2, \#226: 2>1, \#245: 1>0, \#249: $1>2$.

Leptodoras marki: no autapomorphies.

Leptodoras oyakawai: \#41: 1>0.

Leptodoras praelongus: \#231: 0>1, \#264: 1>0.

Lithodoras dorsalis: \#175: 0>1.

Megalodoras guayoensis: no autapomorphies.

Megalodoras uranoscopus: no autapomorphies.

Nemadoras elongatus: no autapomorphies.

Nemadoras hemipeltis: \#58: 1>0, \#118: 2>1.

Nemadoras humeralis: \#228: 0>1.

Orinocodoras eigenmanni: \#0: 0>1, \#1: 0-1, \#103: $0>1$.

Ossancora asterophysa: no autapomorphies.

Ossancora eigenmanni: no autapomorphies.

Ossancora fimbriata: \#226: 0>1, \#274: 0>1.

Ossancora punctata: \#35: 0>1, \#41: $1>0$.

Oxydoras kneri: no autapomorphies.

Oxydoras niger: \#218: 0>1*.

Platydoras armatulus: \#37: 0>1, \#94: 0>1, \#103: 0>1, \#104: 0>1, \#105: 0>1, \#113: 2>0, \#121: 0>1.

Platydoras sp.: \#137: 0>1.

Pterodoras granulosus: \#37: 1>0, \#39: 0>3.

Pterodoras rivasi: no autapomorphies.

Rhinodoras boehlkei: \#37: 1>0. 
Rhinodoras dorbignyi: no autapomorphies. Rhinodoras thomersoni: \#41: 1>0, \#310: $1>2$. Rhynchodoras castilloi: no autapomorphies. Rhynchodoras woodsi: no autapomorphies. Scorpiodoras heckelii: \#37: 0>1, \#78: 0>1. Tenellus leporhinus: \#118: 2>1.

Tenellus ternetzi: no autapomorphies.

Tenellus trimaculatus: \#283: 1>0.

Trachydoras brevis: no autapomorphies.

Trachydoras microstomus: no autapomorphies.

Trachydoras nattereri: no autapomorphies.

Trachydoras paraguayensis: \#270: $0>1$.

Trachydoras steindachneri: \#54: 0>1, \#106: 0>1.

Wertheimeria maculata: \#119: 1>0*.

\section{Nodes.}

Node 1 (all taxa except Diplomystidae and Nematogenyidae): \#16: 1>2, \#51: 0>1, \#59: 0>1, \#73: 1>0, \#79: 0>1*, \#102: 0>1,\#147: 0>1*,\#150:0>1*,\#162: 0>1, \#178: 0>1*,\#217: 0>1*,\#222: 1>2,\#257: 0>1,\#269: 0>1.

Node 2 (Ictaluridae, Pangasiidae, Siluridae): \#5: 0>2, \#22: 0>1, \#157: 0>1,\#276: 0>2, \#277: 1>0,\#287: $1>2$.

Node 3 (Pangasiidae, Siluridae): \#74: 0>1, \#177: 1>2, \#217: 1>2, \#276: 2>3, \#287: $2>3$.

Node 4 (all taxa except Diplomystidae, Ictaluridae, Nematogenyidae, Pangasiidae, Siluridae): \#58: 0>2, \#102: 1>2, \#154: 1>0,\#303: 0>2, \#309: 0>1, \#310: 0>1.

Node 5 (Amphiliidae, Malapteruridae): \#62: 0>1, \#138: 0>1, \#152: 0>1,\#164: 0>1, \#227: 0>1, \#232: 0>1, \#233:0>1, \#235: 0>1, \#257: 1>0,\#259: 0>1, \#287: 1>0,\#305: 1>2, \#306: $1>0$.

Node 6 (Ariidae, Aspredinidae, Claroteidae, Doradoidea, Mochokidae, Heptapteridae, Pimelodidae, Pseudopimelodidae, Sisoroidea): \#40: 0>1, \#58: 1>2, \#102: 2>3, \#126: 0>1, \#127: 0>1, \#167: 1>0.

Node 7 (Ariidae, Claroteidae, Pimelodidae): \#20: 0>1, \#74: 0>1, \#113: 2>3,\#114: 0>1,\#157: 0>1, \#166: 0>1.

Node 8 (Claroteidae, Ariidae): \#58: 2>0,\#75: 0>1, \#80: 0>1, \#127: 1>0,\#141: 0>1*,\#145: 0>1,\#151: 0>1*,\#168: 1>0, $\# 197:$ 1>0,\#245: 0>1, \#254: 0>1.

Node 9 (Ariidae): \#6: 0>3, \#7: 0>1, \#85: 0>1, \#126: 1>0,\#162: 1>2, \#177: 1>0,\#181: 1>0,\#182: 1>0,\#242: 0>1, \#250: 0>1, \#253: 0>1, \#254: $1>2$.

Node 10 (Aspredinidae, Doradoidea, Mochokidae, Pseudopimelodidae, Sisoroidea): \#40: 1>0,\#60: 1>0, \#168: 1>0, \#171: 0>1, \#208: 2>0*, \#221: 2>1, \#222: 2>0, \#308: 0>1, \#310: $1>2$.

Node 11 (Aspredinidae, Doradoidea, Mochokidae, Sisoroidea): \#6: 0>2, \#52: 0>1, \#80: 0>1, \#88: 0>1, \#89: 0>1, \#126: 1>0,\#127: 1>0,\#155: 0>1*,\#177: 1>0,\#216: 0>1, \#220: 0>1, \#236: 0>1* \#309: 1>2.

Node 12 (Aspredinidae, Sisoroidea): \#23: 0>1, \#90: 0>1*, \#91: 0>1*, \#111: 0>1, \#191: 0>1, \#192: 0>1, \#196: 0>1, \#211: 1>2, \#215: 0>1*,\#221: 1>2, \#232: 0>1, \#233: 0>1, \#270: 0>1, \#278: $1>0$.

Node 13 (Sisoridae, Erethistidae): \#6: 2>1, \#7: 0>1, \#22: 0>1, \#24: 0>1*,\#52: 1>0,\#167: 0>1, \#168: 0>1,\#176: 0>1, \#228: 0>1, \#257: 1>0,\#282: 0>1.
Node 14 (Doradoidea, Mochokidae): \#68: 0>1*, \#85: 0>1, \#169: 0>1*,\#171: 1>0,\#205: 0>2, \#207: 0>1, \#213: 0>1*,\#217: 1>2, \#229: 0>1*,\#234: 0>1*,\#265: 1>2, \#273: 0>1, \#308: $1>0$.

Node 15 (Mochokidae): \#17: 0>1, \#60: 0>1, \#113: 2>0,\#138: 0>1, \#139: 0>1,\#162: 1>0,\#176: 0>1,\#208: 0>1*,\#214: 0>1*, \#216: 1>0,\#220: 1>0,\#254: 0>1, \#276: 0>1.

Node 16 (mochokids Chiloglanis, Synodontis): \#18: 0>1, \#125: 0>2*,\#129: 0>1*,\#130: 0>1*,\#140: 0>1*,\#144: 0>1*,\#277: $1>0$.

Node 17 (mochokids Mochokiella, Mochokus): \#52: 1>0,\#230: 0>1*, \#305: 1>2, \#306: $1>0$.

Node 18 (Doradoidea): \#82: 0>1*,\#83: 0>1*, \#95: 0>1*,\#154: 0>1, \#168: 0>1, \#177: 0>1,\#203: 0>1*,\#204: 0>1*,\#205: 2>3, \#210: 0>1*,\#211: 1>0,\#219: 0>1*,\#222: 0>1,\#242: 0>1, \#250: 0>1,\#309: 2>1.

Node 19 (Auchenipteridae): \#5: 0>2, \#13: 0>1*,\#14: 0>1*, $\# 43: 0>1 *$, \#4: 0>1,\#46: 0>1*,\#50:0>1*,\#84: 0>1, \#97: 0>1, \#117: 0>1,\#159: 0>1, \#167: 0>1, \#191: 0>1, \#217: 1>3, \#285: 0>1, \#287: $1>0$.

Node 20 (Centromochlinae): \#77: 0>1, \#177: 1>0, \#237: 0>1, \#265: 2>1, \#288: 0>1*,\#289: 0>1*,\#291: 0>1.

Node 21 (Centromochlus, Gelanoglanis, Tatia): \#44: 1>0,\#45: 0>1, \#50: 1>0,\#131: 0>1, \#249: 0>2,\#290: 0>1, \#291: 1>2*.

Node 22 (Auchenipterinae): \#46: 1>2*,\#115: 0>1, \#190: 0>1, \#276: $0>1$.

Node 23 (Auchenipterinae, except Tocantinsia): \#85: 1>2, \#181: 1>0, \#182: 1>0, \#183: 1>0, \#245: 0>1.

Node 24 (Asterophysus, Liosomadoras): \#64: 0>1, \#84: 1>0, \#268: $1>0$.

Node 25 (Auchenipterinae except Asterophysus, Liosomadoras, Tocantinsia): \#287: 0>1, \#299: 0>1*.

Node 26 (Pseudauchenipterus, Pseudotatia): \#48: 0>1*, \#59: 1>0, \#60: 0>1, \#77: 0>1, \#249: 0>2.

Node 27 (Auchenipterinae except Asterophysus, Liosomadoras, Pseudauchenipterus, Pseudotatia, Tocantinsia): \#87: 0>1, \#237: 0>1, \#239: 0>1, \#287: 1>2, \#300: 0>1.

Node 28 (Auchenipterichthys, Trachelyichthys, Trachelyopterichthys, Trachelyopterus, Trachycorystes): \#276: 1>3, \#307: 0>1.

Node 29 (Auchenipterichthys, Trachelyopterichthys, Trachelyopterus, Trachycorystes): \#57: 0>1, \#64: 0>1, \#87: 1>0, \#162: 1>2, \#217: 3>4,\#246: 0>1.

Node 30 (Trachelyopterichthys, Trachelyopterus, Trachycorystes): \#54: 0>1, \#94: 0>1, \#106: 0>1, \#113: 2>3.

Node 31 (Trachelyopterus, Trachycorystes): \#35: 0>1, \#116: 0>1, \#161: 0>1*,\#246: $1>0$.

Node 32 (Trachelyopterus): \#106: 1>0,\#181: 0>1, \#182: 0>1, \#242: 1>0,\#248: 0>2, \#253: 0>1, \#276: 3>0,\#306: $1>2$.

Node 33 (Ageneiosus, Auchenipterus, Entomocorus, Epapterus, Pseudepapterus, Spinipterus, Tetranematichthys): \#25: 0>1, \#92: 0>1, \#98: 0>1, \#117: 1>0,\#134: 0>1,\#183: 0>1,\#241: 0>1, \#283: 0>1, \#285: $1>0$.

Node 34 (Ageneiosus, Auchenipterus, Entomocorus, Epapterus, Pseudepapterus, Tetranematichthys): \#63: 
0>1,\#116: 0>1, \#257: 1>0,\#287: $2>3$.

Node 35 (Ageneiosus, Tetranematichthys): \#10: 0>1*, \#16: 2>1, \#57: 0>1, \#62: 0>1, \#73: 0>1,\#163: 0>1, \#164: 0>1, \#170: 0>1, \#175: 0>1, \#177: 1>2,\#185: 0>1, \#195: 0>1*, \#223: 0>1*,\#225: 0>1*,\#228: 0>1,\#231:0>1,\#237: 1>0, \#240: 0>1*,\#248: 0>1,\#255: 0>1*,\#265: $2>1$.

Node 36 (Ageneiosus): \#16: 1>0, \#25: 1>0, \#39: $0>2$, \#44: $1>2$, $\# 134: 1>0, \# 135: 0>1 *$, \#244: 0>1*,\#245: 1>0,\#256: 0>1*, \#265: $1>0$.

Node 37 (Auchenipterus, Entomocorus, Epapterus, Pseudepapterus): \#20: 0>1, \#26: 0>1*,\#52: 1>0,\#108: 0>1*, \#109: 0>1*,\#110: 0>1*,\#128: 0>1,\#131: 0>1,\#142: 0>1, \#143: 0>1, \#159: 1>0,\#160: 0>1,\#162: 1>2,\#181: 0>1, \#182: 0>1, \#191: 1>0, \#242: 1>0, \#284: 0>1*, \#286: 0>1*, \#300: 1>0,\#304: $0>1 *$.

Node 38 (Auchenipterus, Epapterus, Pseudepapterus): \#19: 0>1, \#21: 0>1, \#28: 0>1*, \#47: 0>1*, \#64: 0>1, \#69: 0>1, \#76: 0>1, \#96: 0>1*,\#127: 0>1,\#183: 1>2, \#186: 0>2, \#216: 1>0,\#222: 1>2, \#239: 1>0,\#245: 1>0,\#262: $0>1, \# 270: 0>2$, \#273: 1>0,\#276: 1>3,\#281:0>1*,\#283: 1>2,\#292: 0>1*.

Node 39 (Epapterus, Pseudepapterus): \#128: 1>2, \#143: 1>2, \#221: 1>0,\#228: 0>1, \#231: 0>1, \#238: 1>0*,\#248: 0>1.

Node 40 (Doradidae): \#118: 0>1, \#137: 0>1, \#212: 0>1*, \#213: 1>2*, \#217: 2>1, \#253: 0>1, \#306: $1>0$.

Node 41 (Wertheimerinae): \#154: 1>2, \#162: 1>2, \#221: $1>2$.

Node 42 (Doradidae except Wertheimerinae): \#52: 1>0, \#118: 1>2, \#222: 1>0,\#224: $0>1$.

Node 43 (Acanthodoras, Agamyxis, Astrodoradinae, Doradinae): \#5: 0>1, \#99: 0>1, \#137: 1>0,\#154: 1>0, \#264: 0>1, \#267: 0>1, \#276: $0>1$.

Node 44 (Acanthodoras, Agamyxis, Astrodoradinae): \#5: 1>2, \#85: 1>2,\#97: 0>1,\#268: 1>2, \#272: $0>1$.

Node 45 (Acanthodoras, Agamyxis, Astrodoras, Scorpiodoras): \#61: 0>1, \#106: $0>1$.

Node 46 (Acanthodoras, Agamyxis, Astrodoras): \#35: 0>1, $\# 121: 0>1$.

Node 47 (Acanthodoras, Agamyxis): \#0: 0>1, \#57: 0>1, \#85: 2>1, \#103: 0>1, \#104: 0>1, \#105: 0>1, \#113: 2>1, \#123: $1>0$, $\# 162: 1>2$, \#224: 1>0,\#247:0>1,\#260: 0>2, \#276: 1>0, \#302: $0>1 *$

Node 48 (Doradinae): \#36: 0>1, \#217: 1>3, \#245: 0>1, \#274: 0>1, \#306: $0>1$, \#310: $2>1$.

Node 49 (Centrochir, Platydoras): \#1: 0>1, \#38: $0>1$.

Node 50 (Platydoras): \#0: 0>1, \#106: 0>1, \#301: 0>1.

Node 51 (Doradinae, except Centrochir, Platydoras): \#23: 0>1, \#37: 0>1, \#41: 0>1, \#113: 2>1, \#148: 0>1, \#222: 0>1, \#267: $1>0$.

Node 52 (Centrodoras, Doraops, Lithodoras, Megalodoras, Pterodoras): \#41: 1>2, \#221: $1>2$.

Node 53 (Centrodoras hasemani, Doraops, Lithodoras, Megalodoras, Pterodoras):\#123: 1>0, \#148: 1>0.

Node 54 (Doraops, Lithodoras, Megalodoras, Pterodoras): \#40: 0>1, \#104: 0>1, \#217: 3>4.

Node 55 (Megalodoras): \#272: 0>1.

Node 56 (Doraops, Lithodoras, Pterodoras): \#5: 1>0, \#52:
0>1, \#99: 1>0,\#113: 1>2, \#274: $1>0$.

Node 57 (Lithodoras, Pterodoras): \#97: 0>1, \#103: 0>1.

Node 58 (Pterodoras): \#85: $1>2$.

Node 59 (Orinocodoras, Oxydoras, Rhinodoras, Rhynchodoras, fimbriate-barbel doradids): \#5: 1>0, \#99: 1>0, \#122: 1>0, \#137: $0>1$.

Node 60 (Orinocodoras, Rhinodoras, Rhynchodoras): \#113: 1>2, \#149: 0>1, \#156: 0>1*,\#266: 0>1, \#301:0>1.

Node 61 (Rhynchodoras): \#30: 0>1, \#33: 0>1, \#37: 1>0, \#39: $0>2$, \#41: 1>0,\#85: 1>2, \#124: 0>1*, \#216: 1>0,\#228: 0>1, \#231: 0>1, \#273: $1>0$.

Node 62 (Orinocodoras, Rhinodoras): \#3: 0>1*, \#40: 0>1, \#122: 0>1, \#180: 0>3, \#200: 0>1*,\#222: $1>0$.

Node 63 (Rhinodoras): \#15: 0>1*,\#175: $0>1$.

Node 64 (Oxydoras, fimbriate-barbel doradids): \#38: 0>1, \#52: 0>2, \#55: 0>1*, \#93: 0>1*,\#107: 0>1, \#125: 0>1*, \#128: $0>1, \# 131: 0>1, \# 143: 0>1, \# 172: 0>1 *, \# 174: 0>1$, \#179: 0>1, \#180: 0>1, \#188: 0>1*,\#193: 0>1*, \#199: 0>1, \#249: $0>1$, \#271: $0>1 *$, \#274: $1>0$.

Node 65 (Oxydoras): \#40: 0>1, \#58: 2>1, \#65: 0>1*,\#128: 1>2, \#143: 1>2,\#173: 0>1,\#174: 1>2,\#175: 0>1, \#180: $1>2$.

Node 66 (fimbriate-barbel doradids): \#5: 0>2, \#11: $0>1 *$, \#19: $0>1$, \#21: $0>1$, \#23: 1>0, \#37: 1>0, \#73: 0>1, \#84: 0>1, \#85: 1>2, \#113: 1>0,\#120: 0>1*,\#153: 0>1*,\#164: 0>1, \#206: $0>1$, \#222: $1>0$, \#266: $0>2$, \#283: $0>1 / 2$.

Node 67 (Ossancora): \#131: 1>0, \#249: 1>0, \#270: 0>1, \#272: $0>1$, \#283: $1>2$.

Node 68 (Ossancora asterophysa, O. eigenmanni, O. fimbriata): \#12: $0>1 *$, \#17: 0>1, \#231:0>1.

Node 69 (Ossancora asterophysa, O. eigenmanni): \#18: 0>1. Node 70 (fimbriate-barbel doradids except Ossancora): \#30: 0>1, \#78: 0>1, \#128: 1>2, \#165: 0>1*,\#182: $1>2$.

Node 71 (Trachydoras): \#35: $0>1$, \#55: 1>2*, \#58: $2>0$, \#81: 0>2*, \#101: 0>1*, \#143: 1>2, \#179: 1>0, \#180: 1>0, \#181: 1>2, \#189: 0>1*, \#249: 1>2, \#283: $1>2$.

Node 72 (Trachydoras paraguayensis, T. steindachneri): \#272: $0>1$.

Node 73 (fimbriate-barbel doradids except Ossancora, Trachydoras): \#36: $1>0, \# 53: 0>1 *$, \#173: $0>1$.

Node 74 (Doras): \#31: 0>1*, \#41: 1>0, \#62: 0>1.

Node 75 (Doras carinatus, D. higuchii): \#37: 0>1, \#86: 0>1, \#100: 0>1, \#128: $2>1$.

Node 76 (Anduzedoras, Hassar, Hemidoras, Leptodoras, Nemadoras, Tenellus): \#174: 1>2, \#182: 2>1, \#226: 0>1, \#231: $0>1$.

Node 77 (Hemidoras): \#17: 0>1,\#30: 1>0,\#35: 0>1, \#266: 2>0, \#272: $0>1$.

Node 78 (Hemidoras morei, H. morrisi, H. stenopeltis): \#32: 0>1, \#106: $0>1$.

Node 79 (Hemidoras morei, H. morrisi):\#143: 1>2, \#283: $1>2$. Node 80 (Anduzedoras, Hassar, Leptodoras, Nemadoras, Tenellus): \#58: $2>1$.

Node 81 (Nemadoras): \#42: $0>1$, \#283: $1>0$.

Node 82 (Anduzedoras, Hassar, Leptodoras, Tenellus): \#2: 0>1, \#58: 1>0, \#62: $0>1$. 
Node 83 (Tenellus): \#1: $0>1$.

Node 84 (Tenellus ternetzi, T. trimaculatus): \#228: 0>1.

Node 85 (Anduzedoras, Hassar, Leptodoras): \#86: 0>1, \#100: $0>1$, \#174: 2>1, \#182: $1>2$.

Node 86 (Hassar): \#81: 0>1*,\#118: 2>1, \#128: 2>1.

Node 87 (Anduzedoras, Leptodoras): \#8: 0>1*, \#186: 0>1, \#191: 0>1,\#201: 0>1*,\#222: 0>1, \#226: $1>2$.

Node 88 (Leptodoras): \#1: 0>1, \#143: 1>2, \#194:0>1*, \#231: 1>0, \#275: 0>1*, \#283: $1>0$.

Node 89 (Leptodoras juruensis, L. praelongus): \#33: 0>1, \#39: $0>2$, \#202: $0>2 *$.

Submitted August 28, 2012 Accepted February 7, 2014 by Fabio Di Dario Published September 30, 2014 